SEDIMENT-TRANSPORT CHARACTERISTICS AND EFFECTS OF

SEDIMENT TRANSPORT ON BENTHIC INVERTEBRATES IN

THE FOUNTAIN CREEK DRAINAGE BASIN UPSTREAM

FROM WIDEFIELD， SOUTHEASTERN COLORADO， 1985-88

By Pau1 von Guerard

U.S. GEOLOGICAL SURVEY

Water-Resources Investigations Report 89-4161

Prepared in cooperation with the

CITY OF COLORADO SPRINGS DEPARTMENT OF UTILITIES

Denver, Colorado 1989 
DEPARTMENT OF THE INTERIOR

MANUEL LUJAN, JR., Secretary

U.S. GEOLOGICAL SURVEY

Dallas L. Peck, Director

For additional information write to:

District Chief

U.S. Geological Survey

Box 25046, Mail Stop 415

Federal Center

Denver, CO 80225-0046
Copies of this report can be purchased from:

U.S. Geological Survey Books and Open-File Reports Section Box 25425

Federal Center

Denver, CO 80225-0425 
Introduction-

Purpose and scope--

Description of study area-

Acknowledgments--

Sediment-transport characteristics--

Suspended sediment
Suspended-sediment discharge-

Comparison of suspended-sediment yield in Fountain and Monument

Creeks to suspended-sediment yield of other streams in Colorado---

Bed material and bedload-

Stream-channel cross sections-

Fountain Creek-

Monument Creek-

Benthic invertebrates-

Sampling methods and sampling-site descriptions--

Collection-

Fountain Creek---

Monument Creek---0-0.-

Benthic-invertebrate composition and occurrence---

Fountain Creek-

Monument Creek---

Comparison of sampling results between sites-

Similarity indices-

Comparison of densities of organisms between sites----

Comparison with other studies-

Effects of sediment transport on benthic invertebrates--

Summary and conclusions-

References cited--

Supplemental information-

Page

\section{FIGURES}

Figure 1. Map showing location of Fountain Creek drainage basin upstream

from Widefield and location of sampling sites-.-.

2-6. Graphs showing:

2. Example of streamflow hydrograph and benthic-invertebrate sampling periods for Fountain and Monument Creeks------

3. Uncorrected regression line and the regression line corrected for transformation bias for relation of suspended-sediment discharge to streamflow for Fountain Creek near Colorado Springs (site F4)

4. Mean annual suspended-sediment yield for suspendedsediment sampling sites on Fountain Creek for water years 1985-88-1

5. Mean annual suspended-sediment yield for suspendedsediment sampling sites on Monument Creek for water years 1985-88-0. 
Figures 2-6. Graphs showing--Continued:

Page

6. Relation between percentage of annual suspendedsediment load and streamflow for suspended-sediment sampling sites on Fountain (A) and Monument (B) Creeks, water years 1985-88-1A

7. Map showing location of selected suspended-sediment sampling sites in Colorado used for comparison to sites on Fountain and Monument Creeks-8-20. Graphs showing:

8. Relation of streamflow and bedload discharge as a percentage of total sediment discharge for bedloadsampling sites on Fountain and Monument Creeks-----

9. Selected stream-channel cross-section surveys for Fountain Creek at Security (site F13)

10. Mean percentage composition of major taxonomic groups collected at selected sites on Fountain and Monument Creeks during spring (April)

11. Mean percentage composition of major taxonomic groups collected at selected sites on Fountain and Monument Creeks during early summer (late June to early July)

12. Mean percentage composition of major taxonomic groups collected at selected sites on Fountain and Monument Creeks during late summer (mid-August to early September) -

13. Mean percentage composition of major taxonomic groups collected at selected sites on Fountain and Monument Creeks during fall (late October to early November)-

14. Example of a box plot-_.

15. Box plot of mean densities of organisms for all taxa and major taxonomic groups for benthic invertebrates collected on Fountain and Monument Creeks--.--

16. Selected stream-channel cross-section surveys for Fountain Creek near Colorado Springs (site F4)-----

17. Selected stream-channel cross-section surveys upstream from streamflow-gaging station Fountain Creek at Colorado Springs (site F8)

18. Selected stream-channel cross-section surveys downstream from streamflow-gaging station Fountain Creek at Colorado Springs (site F8)--..-

19. Selected stream-channel cross-section surveys for Monument Creek above North Gate Boulevard at U.S. Air Force Academy (site M5)

20. Selected stream-channel cross-section surveys for Monument Creek at Pikeview (site M10) 
Table 1. Chemical quality, sediment, and benthic-invertebrate sampling sites---_-n 5

2. Summary of streamflow for selected sites on Fountain and Monument Creeks---.--

Page

3. Summary of suspended-sediment concentration and percentage of suspended sediment finer than 0.062 millimeters at selected sites on Fountain and Monument Creeks, water years 1985-88--

4. Suspended-sediment-transport equations derived from measurements of suspended-sediment discharge for Fountain and Monument Creeks during water years 1985-88---0.--

5. Summary of annual suspended-sediment and suspended-sand loads and mean annual suspended-sediment yields at selected sites on Fountain and Monument Creeks, water years 1985-88-------

6. General drainage-basin characteristics and summary of mean annual streamflow and mean annual suspended-sediment yield for selected streams in Colorado during water years 1977-82-

7. Results of bedload sampling for selected sediment-sampling sites on Fountain and Monument Creeks, water years 1985-88--

8. Median grain-size statistics for bed-material and bedload samples for selected sites on Fountain and Monument Creeks, water years 1985-88---1

9. Summary of calculations for sediment-particle sizes at threshold of movement---1.--

10. Summary of water-quality properties and constituents measured at sites on Fountain and Monument Creeks, water years

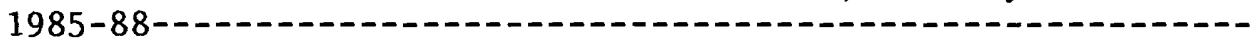

11. Summary of mean densities of organisms for major taxonomic groups and for all taxa for benthic invertebrates collected at selected sites on Fountain and Monument Creeks, water years 1985-88--1.--

ummary of values of similarity index and percent similarity for benthic-invertebrate sampling sites on Fountain and Monument Creeks, water years 1985-88--.-.-

13. Streamflows used to determine flooding during the 30 days prior to collection of benthic invertebrates--.-.--

14. Variation in total organisms and major taxa of benthic invertebrates accounted for by independent variables included in the best regression model for Fountain and

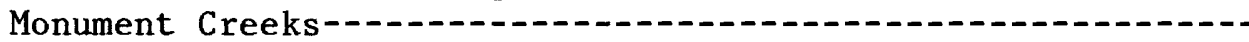

15. Suspended-sediment size distribution for samples collected during snowmelt and rainfall runoff for selected sites on Fountain and Monument Creeks, water years 1985-88---.---

16. Bed-material size distribution for selected sites on Fountain and Monument Creeks, water years 1985-88-10.--

17. Bedload size distribution for selected sites on Fountain and Monument Creeks, water years 1985-88---1----

18. Summary of stream-channel cross-section data for selected sites on Fountain and Monument Creeks, water years 1985-88--

19. Species list, replicate samples, and mean density of benthic invertebrates for selected sites on Fountain and Monument Creeks, water years 1985-88- 


\section{CONVERSION FACTORS}

Inch-pound units used in this report may be converted to metric (International System) units by using the following conversion factors:

Multiply inch-pound unit

acre-foot per square mile

cubic foot per second $\left(f t^{3} / s\right)$

foot ( $f t$ )

inch (in.)

mile (mi)

square foot $\left(\mathrm{ft}^{2}\right)$

square mile $\left(\mathrm{mi}^{2}\right)$

ton (short)

ton per day (ton/d)

day per foot (ton/d/ft)

ton per square mile $\left(\right.$ ton $\left./ \mathrm{mi}^{2}\right)$
$B y$

0.000476

0.028317

0.3048

25.4

1.609

0.09290

2.590

0.9072

0.9072

To obtain metric unit

cubic hectometer per

square kilometer

cubic meter per second

meter

millimeter $(\mathrm{mm})$

kilometer

square meter

square kilometer

megagram

megagram per day ton per

megagram per day per meter

0.3503

megagram per square

kilometer

Temperature can be converted from degree Fahrenheit ( $\left.{ }^{\circ} \mathrm{F}\right)$ to degree Celsius $\left({ }^{\circ} \mathrm{C}\right)$ by using the following equation:

$$
{ }^{\circ} \mathrm{C}=5 / 9\left({ }^{\circ} \mathrm{F}-32\right) \text {. }
$$

The following terms and abbreviations also are used in this report:

microsiemens per centimeter at 25 degrees Celsius $\left(\mu \mathrm{S} / \mathrm{cm}\right.$ at $\left.25^{\circ} \mathrm{C}\right)$. milligram per liter (mg/L)

millimeter $(\mathrm{mm})$

Suspended-sediment concentrations are reported only in milligrams per liter $(\mathrm{mg} / \mathrm{L})$ because these values are (within the range of values presented) numerically equal to concentrations expressed in parts per million.

Sea level: In this report "sea level" refers to the National Geodetic Vertical Datum of 1929 (NGVD of 1929)--a geodetic datum derived from a general adjustment of the first-order level nets of both the United States and Canada, formerly called Sea Level Datum of 1929. 


\title{
SEDIMENT-TRANSPORT CHARACTERISTICS AND EFFECTS OF SEDIMENT TRANSPORT ON BENTHIC INVERTEBRATES IN THE FOUNTAIN CREEK DRAINAGE BASIN UPSTREAM FROM WIDEFIELD, SOUTHEASTERN COLORADO, 1985-88
}

By Paul von Guerard

\begin{abstract}
Sediment and benthic-invertebrate data were collected during water years 1985 through 1988 in the Fountain Creek drainage basin upstream from Widefield, Colorado. Sediment data collected include suspended-sediment concentrations and particle-size analysis of suspended sediment, bedload, and bed material. The smallest median suspended-sediment concentrations were determined for suspended-sediment samples collected at Monument Creek at Palmer Lake and Monument Creek above North Gate Boulevard, at U.S. Air Force Academy. Maximum and median suspended-sediment concentrations were largest at Fountain Creek near Colorado Springs and Monument Creek at Bijou Street at Colorado Springs. Sediment-transport equations were derived for total suspended-sediment discharge and suspended-sand discharge at seven periodic sampling sites. Annual suspended-sediment loads for water years 1985 through 1988 and mean annual suspended-sediment yields were computed for the seven periodic sampling sites. Mean annual suspended-sediment yield for 1985 through 1988 increased about 73 percent downstream in the Fountain Creek drainage basin primarily as a result of sediment discharging from Monument Creek. Mean annual suspended-sediment yields decreased about 30 percent in the lower part of the Fountain Creek drainage basin. In the downstream parts of the Monument Creek drainage basin, mean annual suspended-sediment yield increased about 608 percent.
\end{abstract}

The median grain size of all bed-material samples was very coarse sand to small cobbles, and the median grain size of all bedload samples was coarse sand to very fine gravel. Bedload discharge was computed at six of the periodic sampling sites. Measured bedload discharge ranged from 2.6 to 3,570 tons per day. Bedload discharge, as a percentage of total sediment discharge, ranged from 6 to 92 percent, and the smaller values occurred during rainfall runoff.

Except for 1988, benthic invertebrates were collected four times annually at five of the periodic sampling sites. Number of taxa, species density, and similarity indices were determined for the five sites. At the five benthicinvertebrate sampling sites, 138 taxa were identified; however only 24 were common to all sites. At the benthic-invertebrate sampling sites, changes in streambed elevation was measured periodically during stream-channel crosssection surveys. The more habitat-sensitive benthic invertebrates-Ephemeroptera, Plecoptera, and Trichoptera were most abundant and were most frequently collected at sites where there was little to no change in streambed elevation. 
Multiple comparison tests were used to test for similarity of benthic invertebrates between the five sites. Multiple-regression analysis was done to determine the effects of sediment transport on benthic-invertebrate densities. Median grain size of bed material collected in conjunction with benthic-invertebrate samples and flooding during the 30 days prior to sampling consistently accounted for the most variation in mean densities of total organisms for major taxa groups sampled. Benthic-invertebrate densities were largest at sites with larger median grain size of bed material and that had the fewest periods of flooding during the 30 days prior to sample collection.

\section{INTRODUCTION}

The Fountain Creek drainage basin in southeastern Colorado (fig. 1) has been affected by extensive erosion for more than a century. Chapman (1933) used Fountain Creek as an example of a stream that has been affected by greater than normal erosion rates, which he believed began in the late $1870^{\prime} \mathrm{s}$ as a result of agricultural development. Since 1950, much agricultural area in the basin has been replaced by urban development. Attention of local and state governments has been focused on the effects of changing land use on streams and rivers in the area.

In 1985, the U.S. Geological Survey, in cooperation with the City of Colorado Springs Department of Utilities, began a study to determine the sediment-transport characteristics and the effects of sediment transport on benthic invertebrates in the Fountain Creek drainage basin upstream from Widefield. The study area, hereinafter referred to as the basin, is in eastern Teller County and northwestern E1 Paso County upstream from Widefield. The basin includes $495 \mathrm{mi}^{2}$ (square miles) of the Fountain Creek drainage, which also includes the City of Colorado Springs.

\section{Purpose and Scope}

This report defines the sediment-transport characteristics in Fountain and Monument Creeks and describes the effects of sediment transport on benthic invertebrates in Fountain and Monument Creeks. Sediment and benthicinvertebrate data collection began in 1985 and continued through water year 1988. Suspended-sediment data were collected periodically at seven sites; periodic sampling of bedload and collection of bed material occurred at six of the seven sites, and periodic sampling of benthic invertebrates was done four times annually at five sites, except for water year 1988, when only three samples were collected (figs. 1 and 2 ; table 1 ). Suspended-sediment data were used to develop suspended-sediment-transport equations that were used to determine suspended-sediment discharge and yields in Fountain Creek and its main tributary, Monument Creek.

Bedload and bed-material data and periodic measurements of stream-channel cross sections were used to describe streambed stability at benthicinvertebrate sampling sites. The number of organisms, number of taxa, and similarity indices were determined from benthic-invertebrate data collected at five sites (fig. 1; table 1). Multiple-comparison tests were used to test for similarity of the number of benthic invertebrates among the five sites sampled. Multiple-regression analyses were done to determine the effects of selected water-quality properties and constituents, size distribution of bed material, and frequency of flooding on benthic-invertebrate densities. In this report, the term flooding or flood refers to streamflow resulting from snowmelt or rainfall runoff. 
EXPLANATION

7 PERIODIC-BIOLOGICAL, SEDIMENT, AND CHEMICAL MEASUREMENT SITE THAT HAS CONTINUOUS STREAMFLOW GAGING STATION

$\bar{Z}$ PERIODIC-SEDIMENT AND CHEMICAL MEASUREMENT STTE THAT HAS CONTINUOUS

PERIODIC-BIOLOGICAL AND SEDIMENT MEASUREMENT SITE THAT HAS CONTINUOUS

STREAMFLOW GAGING STATION

$\bar{\gamma}$ PERIODIC-SEDIMENT, CHEMICAL, AND STREAMFLOW MEASUREMENT SITE

$\bar{\nabla}$ PERIODIC-CHEMICAL AND STREAMFLOW MEASUREMENT SITE

\ INACTIVE-CHEMICAL MEASUREMENT STTE

F4 NUMBER REFERS TO SAMPLING SITES IN TABLE 1

PERIODIC BED-MATERIAL AND BEDLOAD SAMPLING் SITE
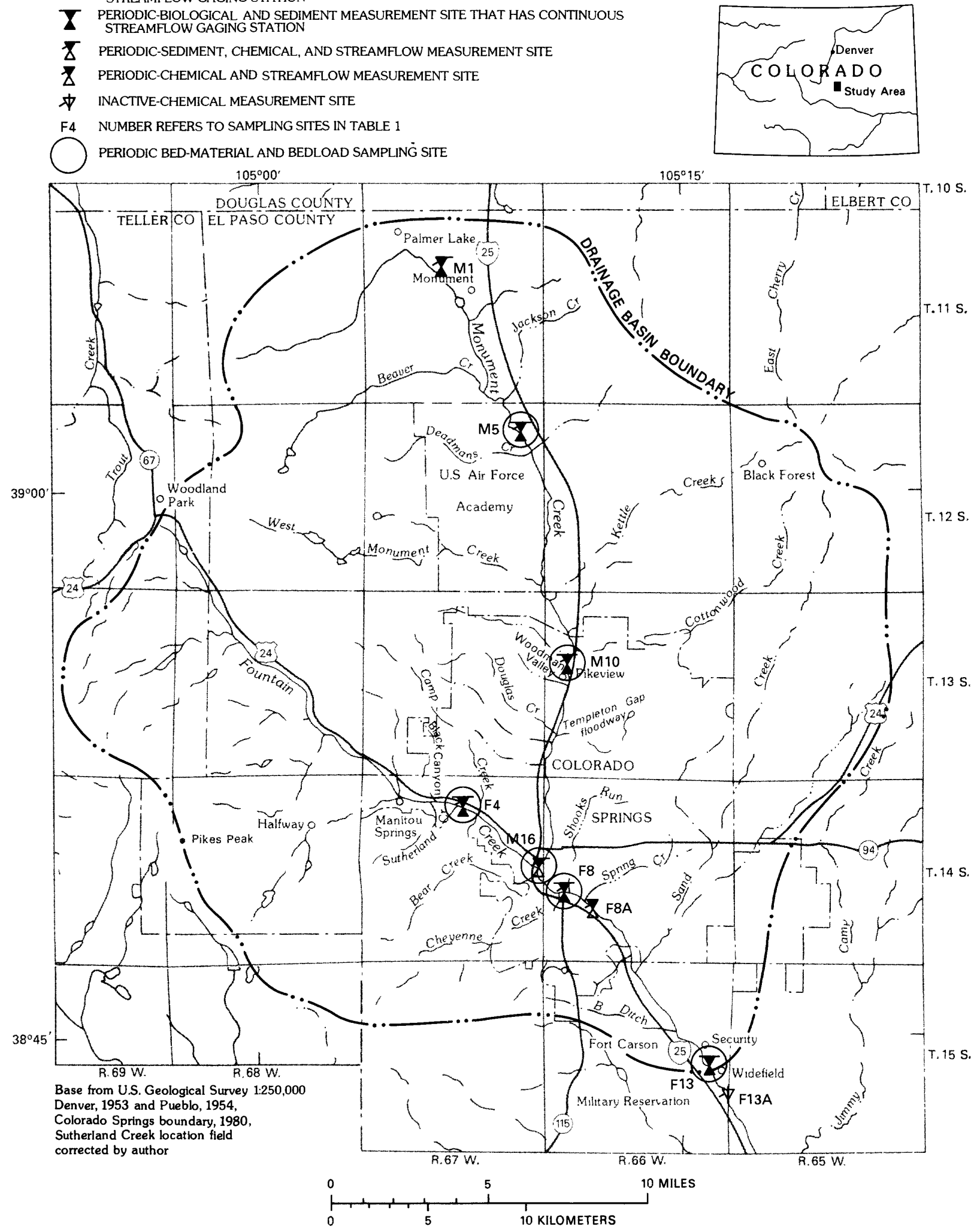

Figure 1.--Location of Fountain Creek drainage basin upstream from Widefield and location of sampling sites. 


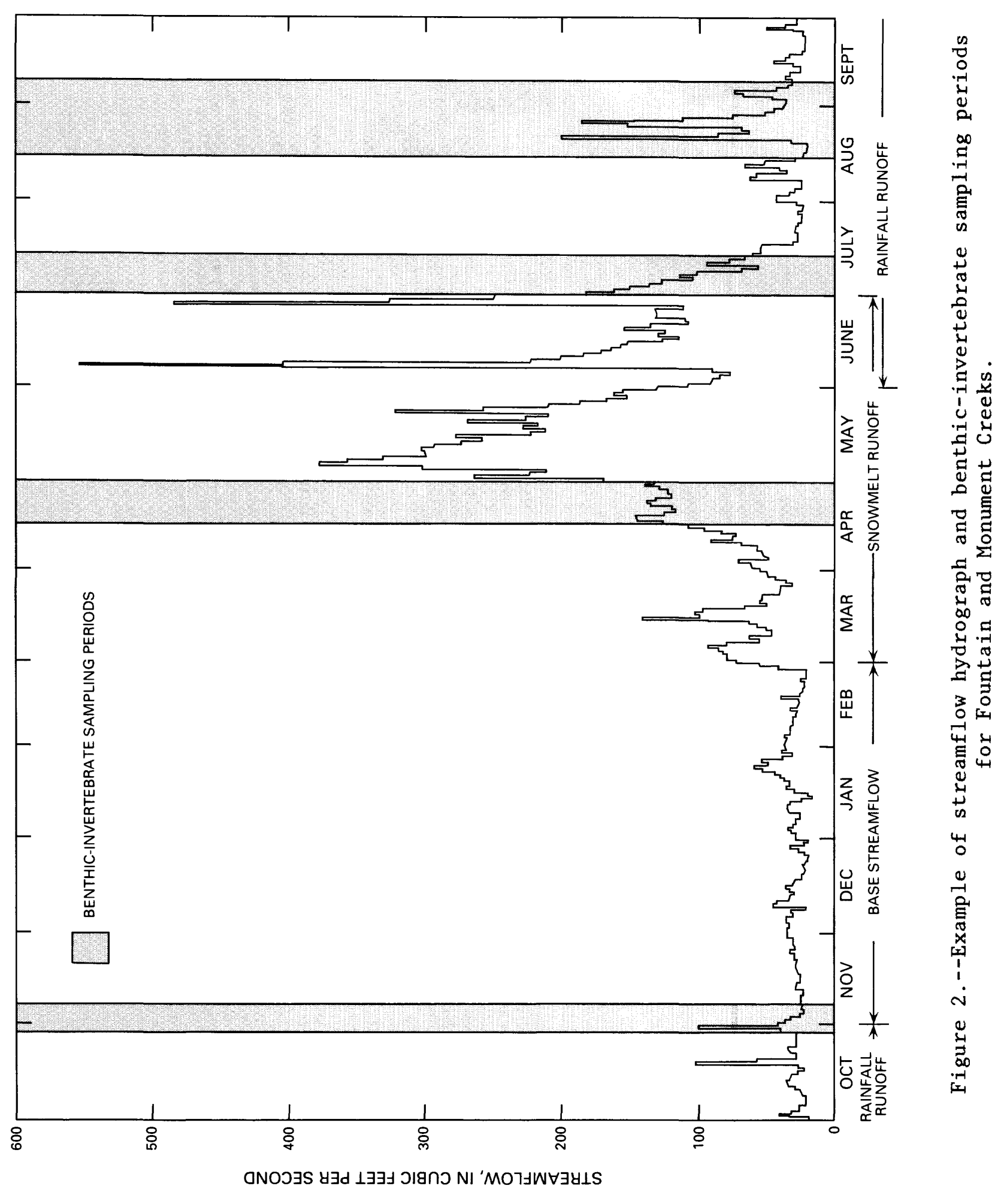




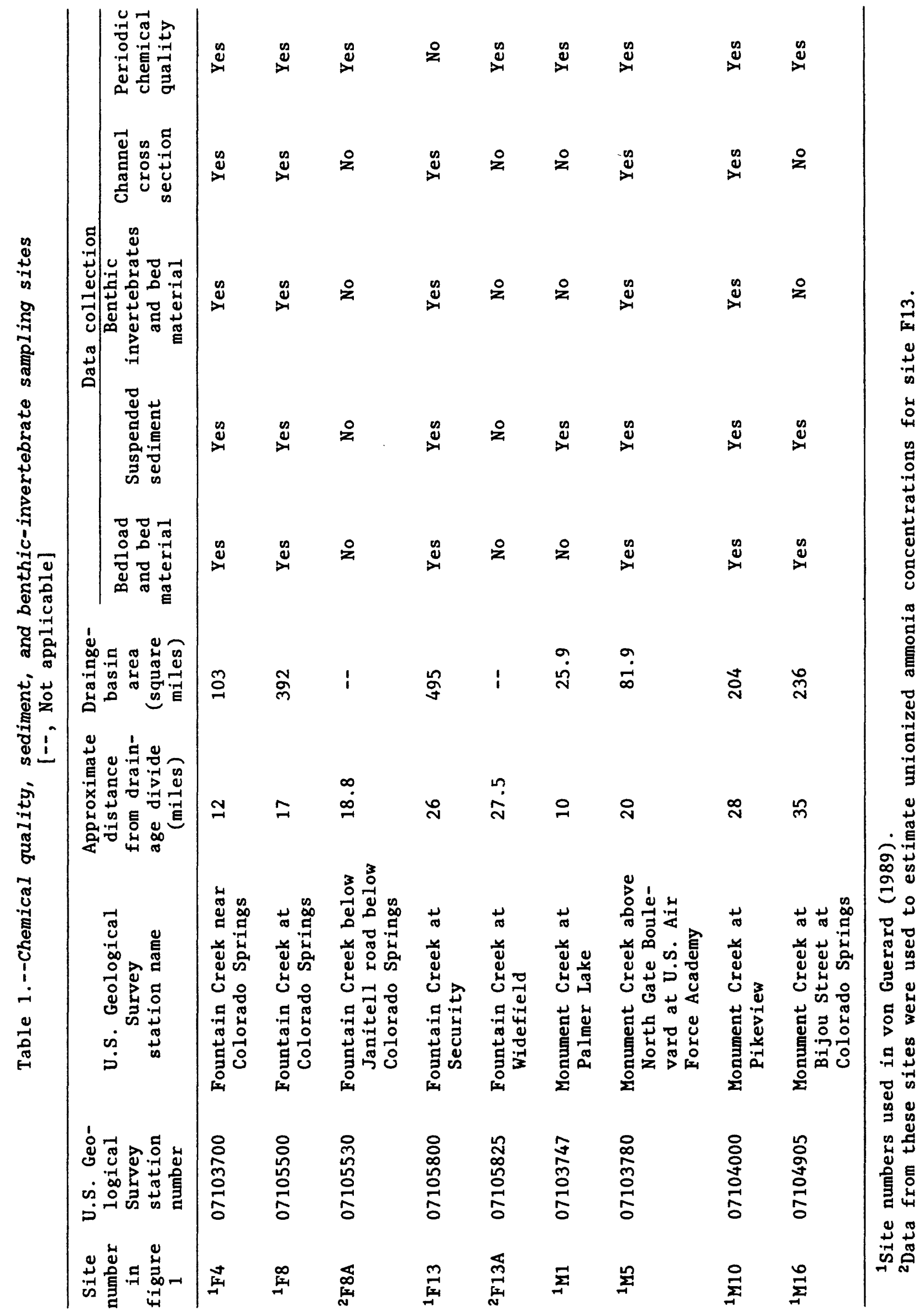




\section{Description of Study Area}

The basin is located in and along the eastern slope of the Front Range section of the southern Rocky Mountains. Elevations in the basin range from $5,640 \mathrm{ft}$ (feet) at the outflow of the basin upstream from Widefield to $14,109 \mathrm{ft}$ at the summit of Pikes Peak. Climatic conditions range from semiarid in areas below $6,500 \mathrm{ft}$ to alpine in areas above $11,500 \mathrm{ft}$. Precipitation within the basin is distributed seasonally as rain and snow. As elevation increases, precipitation as snowfall increases as a part of the total precipitation. Annual precipitation for 1948-87 at the Colorado Springs airport ranged from 8.6 to 25.4 in. (inches). The mean annual precipitation at this location is 15.2 in. Mean annual precipitation from 1951 to 1981 for the entire basin is 18.2 in. (Colorado Climate Center, 1984). Convective thunderstorms contribute most of the rainfall that occurs during May through September. Thunderstorms occur an average of 70 days each year (U.S. Geological Survey 1970, p. 116).

The western one-third of the basin is underlain by granite of Precambrian age, and the remainder of the basin is underlain by sandstone and shale of Cretaceous age and alluvial and windlain deposits of Quaternary age. Soils in the basin tend to be sandy, moderately deep to deep, and well drained to excessively well drained. A more detailed description of the study area is discussed in von Guerard (1989).

\section{Acknowledgments}

The author thanks Steven P. Canton of Chadwick \& Associates, Inc., for his review of this report and for providing insight into the complexities of the benthic-invertebrate communities of Fountain and Monument Creeks. The author also thanks Peter C. McCarville, a streamflow observer in Colorado Springs, for his untiring efforts in collecting suspended-sediment samples. His data collection and information concerning the occurrence of floods was invaluable to the success of this project.

\section{SEDIMENT-TRANSPORT CHARACTERISTICS}

The instream physical habitat available for benthic invertebrates is dependent upon the prevailing flow regime and the sediment transport. Streamflow in the basin is characterized by base streamflow during November through February, snowmelt runoff during March through June, and rainfall runoff during May through October (fig. 2). During most years, there is some overlap of the snowmelt and rainfall-runoff periods. Sewage-treatment-plant effluent affects streamflow at Fountain Creek at Security (site F13) year round (fig 1; table 1) (Kuhn, 1988). Instantaneous minimum, maximum, and mean annual streamflow for selected sites on Fountain and Monument Creeks are listed in table 2. The following is a discussion of the characteristics of suspended sediment and bedload sediment transported in Fountain and Monument Creeks. 
Table 2.--Summary of streamflow for selected sites on Fountain and Monument Creeks

\begin{tabular}{|c|c|c|c|c|c|c|c|c|}
\hline \multirow{3}{*}{$\begin{array}{l}\text { Site } \\
\text { number } \\
\text { in } \\
\text { fig- } \\
\text { ure } 1\end{array}$} & \multirow{3}{*}{$\begin{array}{c}\text { U.S. } \\
\text { Geological } \\
\text { Survey } \\
\text { station } \\
\text { number }\end{array}$} & \multirow{3}{*}{$\begin{array}{l}\text { Period } \\
\text { of } \\
\text { record } \\
\text { (water } \\
\text { year) }\end{array}$} & \multicolumn{6}{|c|}{$\begin{array}{l}\text { Streamflow } \\
\text { (cubic feet per second) }\end{array}$} \\
\hline & & & \multicolumn{3}{|c|}{ For period of record } & \multicolumn{3}{|c|}{$\begin{array}{l}\text { For period of study } \\
\text { (water years 1985-88) }\end{array}$} \\
\hline & & & $\frac{\text { Instan }}{\text { Minimum }}$ & $\frac{\text { taneous }}{\text { Maximum }}$ & $\begin{array}{l}\text { Mean } \\
\text { annual }\end{array}$ & $\frac{\text { Instant }}{\text { Minimum }}$ & $\frac{\text { aneous }}{\text { Maximum }}$ & $\begin{array}{c}\text { Mean } \\
\text { annual }\end{array}$ \\
\hline F4 & 07103700 & $1958-88$ & 2.0 & 2,630 & 14.6 & 2.0 & 229 & 18.7 \\
\hline F8 & 07105500 & $\begin{array}{l}1922-24 ; \\
1977-88\end{array}$ & 2.0 & 6,000 & 63.4 & 11 & 4,450 & 74.8 \\
\hline F13 & 07105800 & $1964-88$ & 1.9 & 25,000 & 84.5 & 51 & 3,800 & 137 \\
\hline M1 & 07103747 & $\begin{array}{l}\text { February } \\
1977-88\end{array}$ & .10 & 216 & 7.5 & .50 & 204 & 7.3 \\
\hline M5 & 07103780 & $\begin{array}{r}\text { April } 19, \\
1985-88\end{array}$ & 1.1 & 372 & 17.5 & 1.1 & 372 & 17.5 \\
\hline M10 & 07104000 & $\begin{array}{l}\text { 1939-49; } \\
\text { January }\end{array}$ & 0.0 & 3,750 & 28.8 & 7.1 & 3,020 & 39.5 \\
\hline M16 & 07104905 & $\begin{array}{l}1976-88 \\
\left({ }^{1}\right)\end{array}$ & $(1)$ & $\left({ }^{1}\right)$ & $\left({ }^{1}\right)$ & $\left({ }^{1}\right)$ & $\left({ }^{1}\right)$ & 245.8 \\
\hline
\end{tabular}

${ }^{1}$ No continuous streamflow data are collected.

${ }^{2}$ Mean annual streamflow was computed from streamflow derived by methods described in von Guerard (1989).

\section{Suspended Sediment}

Suspended sediment is the sediment transported in suspension by the turbulent forces of streamflow or by Brownian movement. Suspended sediment can be described as either fine (silt and clay) or coarse (usually sand). Fine sediments, sediments with particle diameters finer than $0.062 \mathrm{~mm}$ (millimeter), once suspended in the water column will stay in suspension for long periods of time and are transported by most streamflow discharges. The occurrence of suspended sands, sediments with particle diameters that range from $0.062 \mathrm{~mm}$ through $2.0 \mathrm{~mm}$, is dependent on streamflow. Suspended-sediment samples were collected periodically at seven sites in the basin during water years 1985-88 (fig. 1 ; table 1 ). The samples were collected monthly, with increased sampling frequency during periods of snowmelt and rainfall runoff, by using a DH-48 or a D-74 depth-integrating sampler and the equal-widthincrement (equal-transit rate) method described by Guy and Norman (1970). All sediment samples were analyzed for suspended-sediment concentration. Selected samples specifically were analyzed for the percentage of suspended sediment finer than sand size (less than $0.062 \mathrm{~mm}$ ) and for complete particle-size analysis of suspended sediments, including percentage of suspended sediment finer than coarse clay (in the range of 0.002 to $0.004 \mathrm{~mm}$ ), very fine to coarse silt (in the range of 0.004 to $0.062 \mathrm{~mm}$ ), and very fine to coarse sand (in the range of 0.062 to $1.0 \mathrm{~mm}$ ) (Guy, 1969). 
A statistical summary of suspended-sediment concentrations and percentage of suspended sediment finer than $0.062 \mathrm{~mm}$ is listed in table 3 . The smallest median suspended-sediment concentrations were determined for suspendedsediment samples collected at Monument Creek at Palmer Lake (site M1) and Monument Creek above North Gate Boulevard, at U.S. Air Force Academy (site M5) (hereinafter referred to as Monument Creek at USAFA) (table 3). These sites are located in the headwater parts of Monument Creek. Maximum and median suspended-sediment concentrations were largest at Fountain Creek near Colorado Springs (site F4) and Monument Creek at Bijou Street at Colorado Springs (site M16) (table 3). For the seven sites sampled, median values for suspended sediment finer than $0.062 \mathrm{~mm}$ ranged from 55 to 69 percent (table 3 ).

Except for site M1, suspended-sediment samples were collected for complete particle-size analysis at all suspended-sediment sampling sites during periods of snowmelt or rainfall runoff. These data are summarized in table 15 in the "Supplemental Information" section at the back of this report. Silt (in the range of 0.004 to $0.062 \mathrm{~mm}$ ) composed 23 to 61 percent of the suspended sediment. Coarse clay (in the range of 0.002 to $0.004 \mathrm{~mm}$ ) and suspended sediments finer than $0.002 \mathrm{~mm}$ composed 11 to 62 percent of the suspended sediment. Most of the suspended sand in transport in Fountain and Monument Creeks is very fine (in the range of 0.062 to $0.125 \mathrm{~mm}$ ) to fine (in the range of 0.125 to $0.25 \mathrm{~mm}$ ) sand. Medium (in the range of 0.25 to $0.50 \mathrm{~mm}$ ) to coarse sands (in the range of 0.50 to $1.0 \mathrm{~mm}$ ) usually composed less than 10 percent of the suspended sand.

Table 3.--Summary of suspended-sediment concentration and percentage of suspended sediment finer than 0.062 millimeters at selected sites on Fountain and Monument Creeks, water years 1985-88

\begin{tabular}{|c|c|c|c|c|c|c|c|c|c|}
\hline \multirow{2}{*}{$\begin{array}{c}\text { Site } \\
\text { number } \\
\text { in } \\
\text { figure } 1\end{array}$} & \multirow{2}{*}{$\begin{array}{l}\text { U.S. Geolog- } \\
\text { ical Survey } \\
\text { station } \\
\text { number }\end{array}$} & \multirow[t]{2}{*}{$\begin{array}{l}\text { Number } \\
\text { of } \\
\text { samples }\end{array}$} & \multicolumn{3}{|c|}{$\begin{array}{l}\text { Suspended-sediment } \\
\text { concentration, in } \\
\text { milligrams per liter }\end{array}$} & \multirow[t]{2}{*}{$\begin{array}{l}\text { Number } \\
\text { of } \\
\text { samples }\end{array}$} & \multicolumn{3}{|c|}{$\begin{array}{l}\text { Percentage of suspended } \\
\text { sediment finer than } \\
0.062 \text { millimeters } \\
\end{array}$} \\
\hline & & & Minimum & Maximum & Median & & Minimum & Maximum & Median \\
\hline F4 & 07103700 & 161 & 1 & 41,000 & 174 & 141 & 18 & 99 & 69 \\
\hline F8 & 07105500 & 194 & 38 & 27,100 & 1,300 & 187 & 28 & 92 & 59 \\
\hline F13 & 07105800 & 163 & 39 & 25,900 & 925 & 161 & 10 & 95 & 64 \\
\hline M1 & 07103747 & 50 & 1 & 3,610 & 21 & 28 & 35 & 97 & 58 \\
\hline M5 & 07103780 & 125 & 4 & 7,220 & 54 & 100 & 23 & 96 & 55 \\
\hline M10 & 07104000 & 146 & 19 & 26,200 & 685 & 139 & 20 & 89 & 60 \\
\hline M16 & 07104905 & 151 & 53 & 22,200 & 1,820 & 149 & 28 & 96 & 59 \\
\hline
\end{tabular}




\section{Suspended-Sediment Discharge}

Suspended-sediment and streamflow relations were developed using ordinary least-squares regression (Glysson, 1987). Total suspended-sediment discharge (suspended clay, silt, and sand), hereinafter referred to as suspendedsediment discharge, and suspended-sand discharge, were computed for each sediment-sampling site by applying suspended-sediment-transport equations to the daily mean streamflow for each day at each site.

The regression equation estimates the mean response of the dependent variable (suspended-sediment discharge) given known values of the independent variable (streamflow). The form of the regression equation is a linear function of the logarithmic-transformed (natural log) variable:

$$
\ln Y=\ln B_{0}+B_{1} \ln X .
$$

Taking the antilogs, the form of the regression equation becomes:

$$
\mathrm{Y}=\mathrm{B}_{0} \mathrm{X}^{\mathrm{B}_{1}} \text {, }
$$

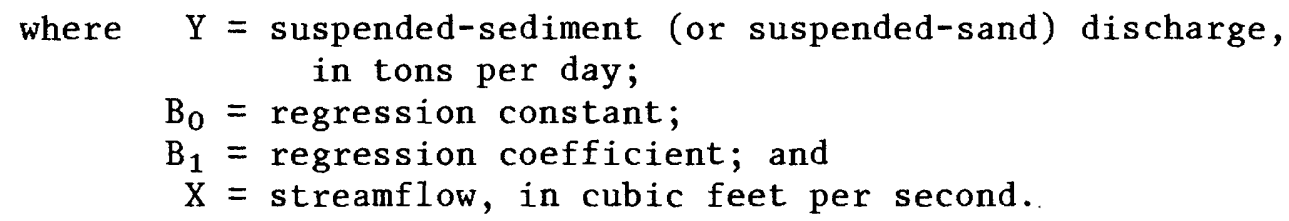

A transformation bias is produced when the logarithms of the estimated mean response (log of suspended-sediment discharge) is retransformed (eq. 2) (Miller, 1984; Cohn and others, 1989). This tranformation bias usually results in underestimation of the retransformed mean response (suspendedsediment discharge). It is possible, however, to eliminate the major part of this transformation bias by multiplying the estimated annual suspendedsediment load by a correction factor (Miller, 1984):

$$
\mathrm{Cb}=\mathrm{e}^{0.5 \mathrm{MSE}} \text {, }
$$

where $\mathrm{Cb}=$ transformation bias-correction factor;

$\mathrm{e}=$ base of the natural logarithm; and

MSE = mean square error of estimate.

Cohn and others (1989) reported that transformation bias-correction factors, such as the one described by Miller (1984), may produce unsatisfactory results when sample sizes $(n)$ are small $(n<50)$ and when mean square error of estimate is large (MSE>1.0). Annual suspended-sediment and suspended-sand loads computed using the equations in table 4 were adjusted using transformation bias-correction factors described by Miller (1984) and Cohn and others (1989). Use of the transformation bias-correction factor proposed by Cohn and others (1989) resulted in annual suspended-sediment and suspended-sand loads that were from 0 to 3 and -1 to 6 percent different than loads obtained using the transformation bias-correction factor described by Miller (1984). A possible explanation of the small differences in results obtained using the two transformation bias-correction factors is that annual suspended-sediment and suspended-sand loads were determined for streamflows within the range of streamflows used to define the regression relations listed in table 4 . 
Table 4.--Suspended-sediment-transport equations derived from measurements of suspended-sediment discharge for Fountain and Monument Creeks during water years 1985-88

[n, sample size; $\mathrm{Cb}$, transformation bias-correction factor; $\mathrm{R}^{2}$, coefficient of multiple determination; MSE, mean square error of estimate, in $\log$ of tons; Qs, total suspended-sediment discharge, in tons per day; Qsa, suspended-sand discharge, in tons per day; $Q$, streamflow, in cubic feet per second]

\begin{tabular}{|c|c|c|c|c|c|c|}
\hline $\begin{array}{l}\text { Site } \\
\text { number in } \\
\text { figure } 1\end{array}$ & $\begin{array}{c}\text { U.S. Geological } \\
\text { Survey } \\
\text { station number }\end{array}$ & $\begin{array}{l}\text { Regression } \\
\text { equation }\end{array}$ & $\mathrm{n}$ & $\mathrm{C}_{\mathrm{b}}$ & $\mathrm{R}^{2}$ & MSE \\
\hline${ }^{1} \mathrm{~F} 4$ & 07103700 & $\begin{aligned} Q s & =0.009 Q^{2.42} \\
Q s a & =0.009 Q^{2.14}\end{aligned}$ & $\begin{array}{l}161 \\
141\end{array}$ & $\begin{array}{l}2.65 \\
1.80\end{array}$ & $\begin{array}{r}0.64 \\
.71\end{array}$ & $\begin{array}{l}1.95 \\
1.18\end{array}$ \\
\hline${ }^{1} \mathrm{~F} 8$ & 07105500 & $\begin{aligned} Q s & =0.01 Q^{2} .20 \\
Q s a & =0.003 Q^{2.26}\end{aligned}$ & $\begin{array}{l}194 \\
187\end{array}$ & $\begin{array}{l}1.50 \\
1.66\end{array}$ & $\begin{array}{l}.89 \\
.86\end{array}$ & $\begin{array}{r}.81 \\
1.01\end{array}$ \\
\hline F13 & 07105800 & $\begin{aligned} Q s & =0.001 Q^{2.45} \\
Q s a & =0.0004 Q^{2.44}\end{aligned}$ & $\begin{array}{l}163 \\
161\end{array}$ & $\begin{array}{l}1.24 \\
1.41\end{array}$ & $\begin{array}{l}.91 \\
.89\end{array}$ & $\begin{array}{l}.58 \\
.69\end{array}$ \\
\hline M1 & 07103747 & $\begin{aligned} Q \mathbf{s} & =0.35 \mathrm{Q}^{0} .99 \\
\mathrm{Qsa} & =0.28 \mathrm{Q}^{0.94}\end{aligned}$ & $\begin{array}{l}50 \\
28\end{array}$ & $\begin{array}{l}1.45 \\
1.85\end{array}$ & $\begin{array}{l}.68 \\
.60\end{array}$ & $\begin{array}{r}.75 \\
1.23\end{array}$ \\
\hline M5 & 07103780 & $\begin{aligned} Q s & =0.078 Q^{1.53} \\
Q s a & =0.057 Q^{1.46}\end{aligned}$ & $\begin{array}{l}125 \\
100\end{array}$ & $\begin{array}{l}1.36 \\
1.51\end{array}$ & $\begin{array}{l}.84 \\
.79\end{array}$ & $\begin{array}{l}.62 \\
.83\end{array}$ \\
\hline M10 & 07104000 & $\begin{aligned} Q s & =0.057 Q^{1.96} \\
Q s a & =0.025 Q^{1.93}\end{aligned}$ & $\begin{array}{l}146 \\
139\end{array}$ & $\begin{array}{l}1.60 \\
1.51\end{array}$ & $\begin{array}{l}.79 \\
.80\end{array}$ & $\begin{array}{l}.94 \\
.83\end{array}$ \\
\hline M16 & 07104905 & $\begin{aligned} Q s & =0.026 Q^{2} .20 \\
Q s a & =0.007 Q^{2.27}\end{aligned}$ & $\begin{array}{l}151 \\
149\end{array}$ & $\begin{array}{l}1.32 \\
1.38\end{array}$ & $\begin{array}{l}.89 \\
.88\end{array}$ & $\begin{array}{l}.56 \\
.64\end{array}$ \\
\hline
\end{tabular}

${ }^{1}$ Regression equations significantly different $(p<0.05)$ than equations used in von Guerard (1989).

Because there is a negligible difference in results obtained using the two transformation bias-correction factors, and because Miller's correction factor is more convenient to use because it is applied equally to all streamflows, Miller's transformation bias-correction factor was used to correct for transformation bias in the equations in table 4. The effects of transformation bias-correction factors for a regression relation of selected suspendedsediment discharge to streamflow (table 4) is shown in figure 3.

The reliability of the regression equations in table 4 can be evaluated by examining the values of the coefficient of multiple determination $\left(R^{2}\right)$ and the mean square error of estimate (MSE) for each regression (table 4). The coefficient of multiple determination is a measure of proportion of total variation in the dependent variable (suspended-sediment discharge) explained by the independent variable (streamflow). Mean square error is a measure of the difference between the predicted and observed values of the dependent variable. The larger the MSE, the greater the variance about the regression line. 


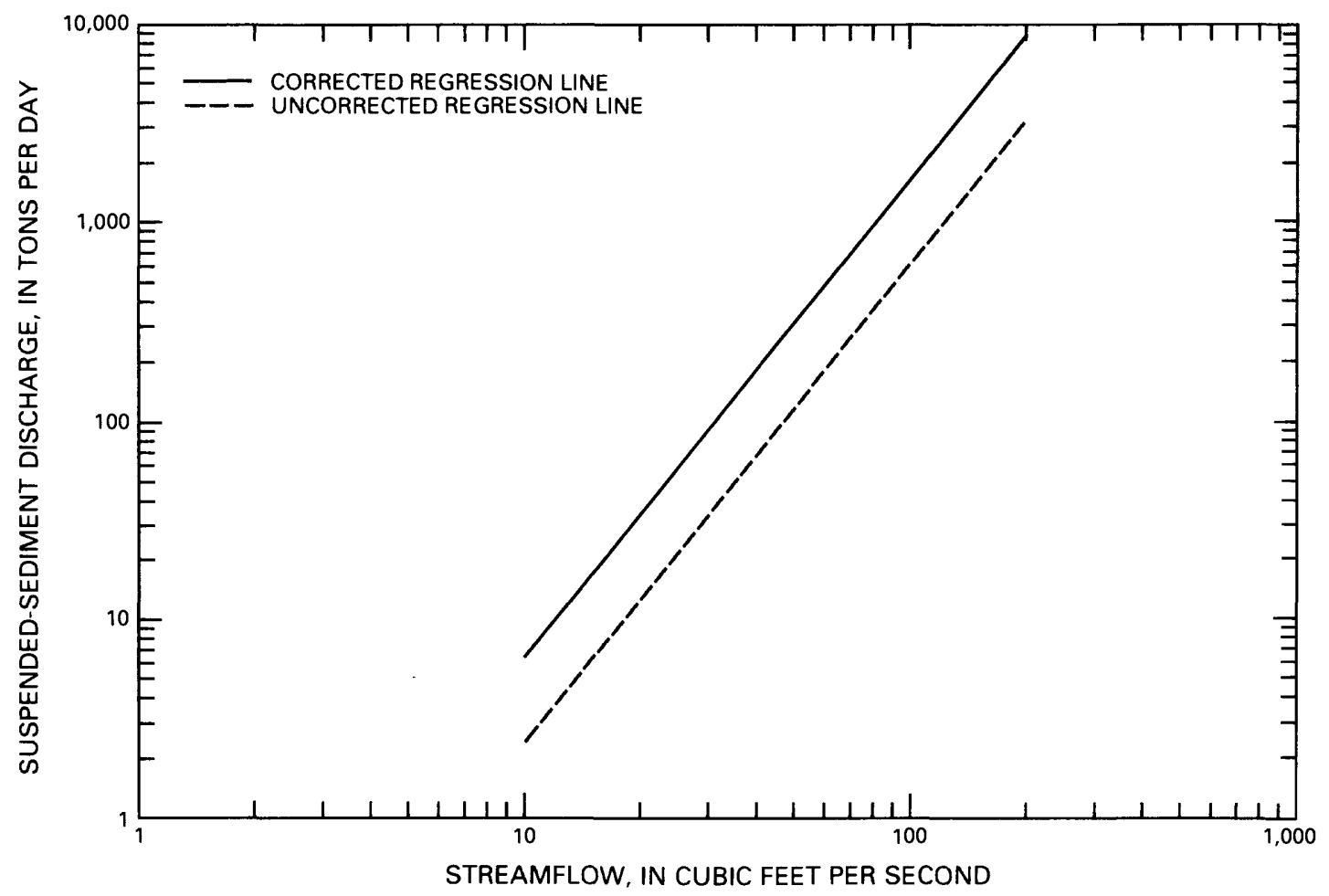

Figure 3.--Uncorrected regression line and the regression line corrected for transformation bias for relation of suspended-sediment discharge to streamflow for Fountain Creek near Colorado Springs (site F4).

Continuous streamflow records are available from six of the periodic suspended-sediment sampling sites. The continuous streamflow record available at Monument Creek at USAFA (site M5), however, began on April 19, 1985 (table 2). Daily mean streamflow at site M5 was estimated for the first 6 months of water year 1985 by comparing the partial record at site M5 with the corresponding record for Monument Creek at Palmer Lake (site M1). These data were compared using ordinary least-squares regression and were determined to be quite similar. The missing record for water year 1985 at site M5 was estimated using the following equation:

$$
\mathrm{Q}_{\mathrm{M} 5}=6.02+\left(2.06 \mathrm{Q}_{\mathrm{M} 1}\right) \text {, }
$$

where $Q_{M 5}=$ daily mean streamflow at Monument Creek at USAFA (site M5), in cubic feet per second; and

$$
\begin{aligned}
Q_{M 1}=\text { daily mean streamflow at Monument Creek at Palmer Lake (site M1), } \\
\text { in cubic feet per second. }
\end{aligned}
$$

For this equation, the coefficient of multiple determination $\left(R^{2}\right)$ is 0.95 .

Daily mean streamflow at Monument Creek at Bijou Street at Colorado Springs (site M16) was estimated from daily streamflow records from nearby sites using techniques described by von Guerard (1989). By use of the 
equations in table 4 for water year 1985, Fountain Creek near Colorado Springs (site F4), Fountain Creek at Colorado Springs (site F8) and Monument Creek at Pikeview (site M10) had substantially larger annual suspended-sediment and suspended-sand loads than were reported in von Guerard (1989). Regression equations derived by von Guerard (1989) from data collected in 1985 were compared to the regression equations listed in table 4 by using analysis of covariance using dummy variables. All regression equations were determined to be not significantly different ( $>0.05)$, except for those derived for sites F4 and F8 $(p<0.05)$. Larger suspended-sediment concentrations were determined, and higher streamflows occurred during water years 1986-88 than during water year 1985. Regression equations developed by von Guerard (1989), based only on data collected during water year 1985, did not include the larger suspended-sediment concentrations at sites $F 4$ and F8 and higher streamflows at site F8 that occurred during water year 1985. This may account for the difference in regression equations derived using data collected during water year 1985 and those derived using data collected during water years 1985-88 for sites F4 and F8.

Annual suspended-sediment and suspended-sand loads and mean annual suspended-sediment yields for water years 1985-88 at the seven suspendedsediment sampling sites are summarized in table 5 . There is an apparent decrease in mean annual suspended-sediment load between sites F8 and F13. However, the difference in suspended-sediment load, about -11 percent, between sites $\mathrm{F} 8$ and $\mathrm{F} 13$ is less than the streamflow measurement and suspendedsediment-sampling error at these sites. Mean annual suspended-sediment yield increased about 73 percent between Fountain Creek near Colorado Springs (site F4) and Fountain Creek at Colorado Springs (site F8) (fig. 4, table 5). Suspended-sediment yield at site F8 is affected greatly by Monument Creek. Mean annual suspended-sediment yields decreased about 30 percent between sites F8 and F13. Mean annual suspended-sand load, as a percent of mean annual suspended-sediment load, was about 21 percent at site F4, about 47 percent at site $F 8$, and about 40 percent at site F13.

Mean annual suspended-sediment load for Monument Creek at Bijou Street at Colorado Springs (site M16), about $0.75 \mathrm{mi}$ upstream from the confluence of Fountain Creek and Monument Creek, was about 74 percent of the mean annual suspended-sediment load at site F8 (table 5). Mean annual suspended-sediment yield increased about 20 percent between Monument Creek at Palmer Lake (site M1) and Monument Creek at USAFA (site M5). Between site M5 and Monument Creek at Pikeview (site M10), mean annual suspended-sediment yield increased about 608 percent (fig. 5, table 5). Mean annual suspended-sediment yield increased about 61 percent between site M10 and Monument Creek at Bijou Street at Colorado Springs (site M16) (fig. 5, table 5). Mean annual suspended-sand load, as a percent of mean annual suspended-sediment load, was about 88 percent at site M1, 61 percent at site M5, about 36 percent at site M10, and about 40 percent at site M16.

Suspended-sediment transport occurs in Fountain and Monument Creeks at all rates of streamflow. However, the majority of suspended sediment is transported by streamflows (floods) in excess of mean annual streamflows for the period of record (figs. 6A-B; table 2). Floods transport the larger part of the annual suspended-sediment load. For example at site M16, about 75 percent of the annual suspended-sediment load is transported by streamflows that exceed $100 \mathrm{ft}^{3} / \mathrm{s}$, which occur about 9 percent of the time. 


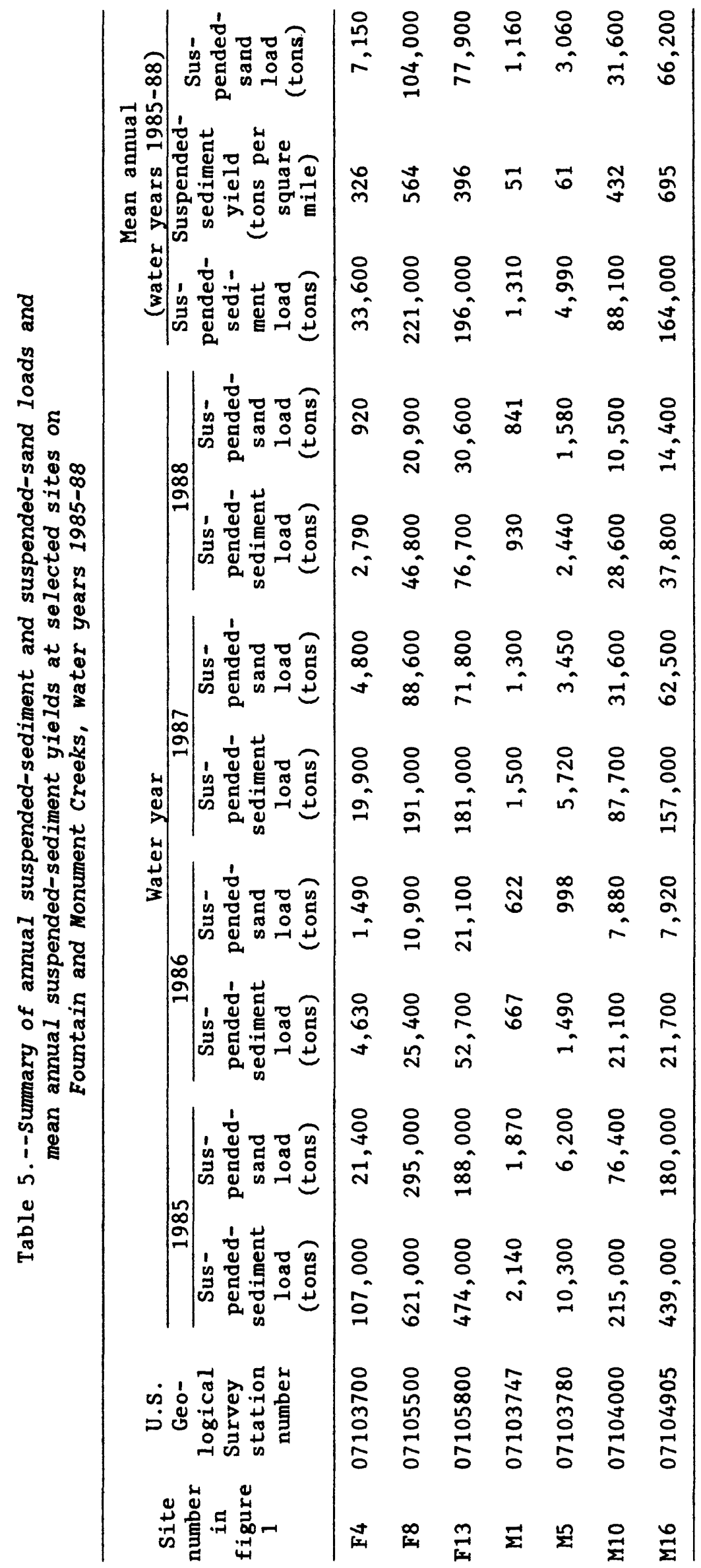




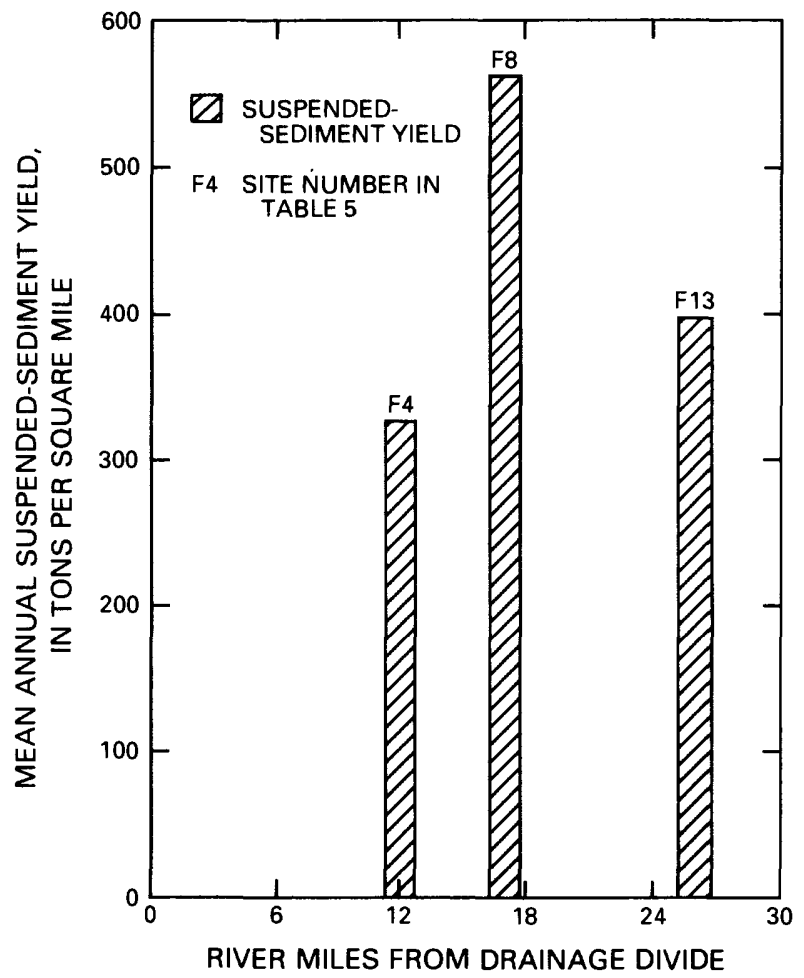

Figure 4.--Mean annual suspended-sediment yield for suspended-sediment sampling sites on Fountain Creek for water years 1985-88.

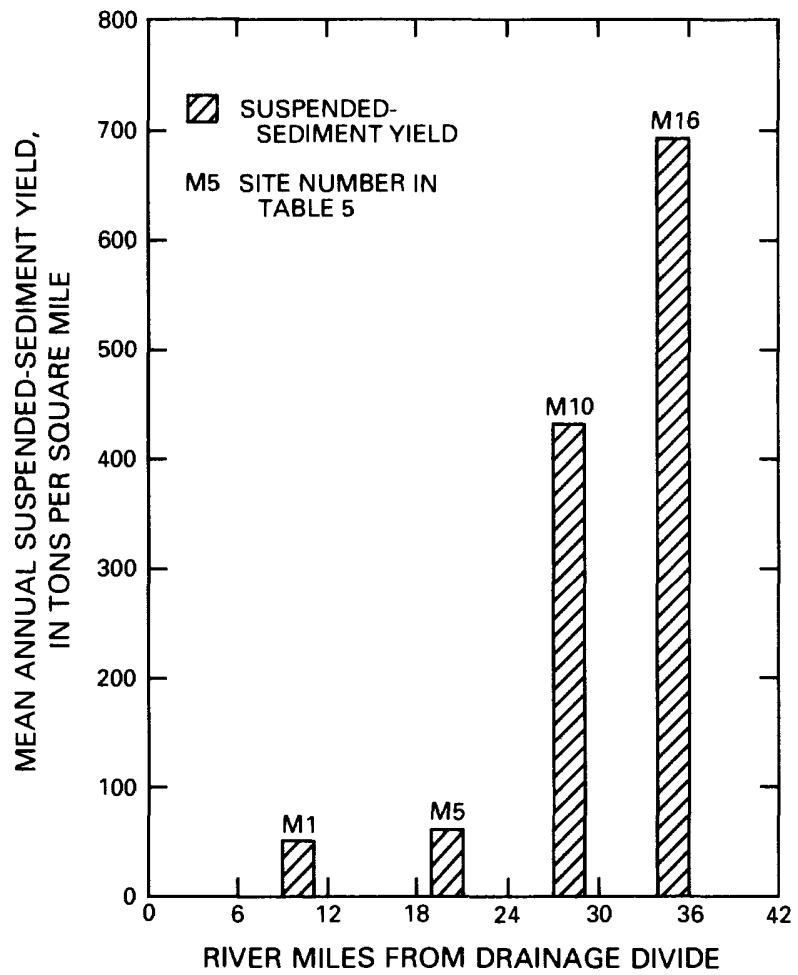

Figure 5.--Mean annual suspended-sediment yield for suspended-sediment sampling sites on Monument Creek for water years 1985-88. 


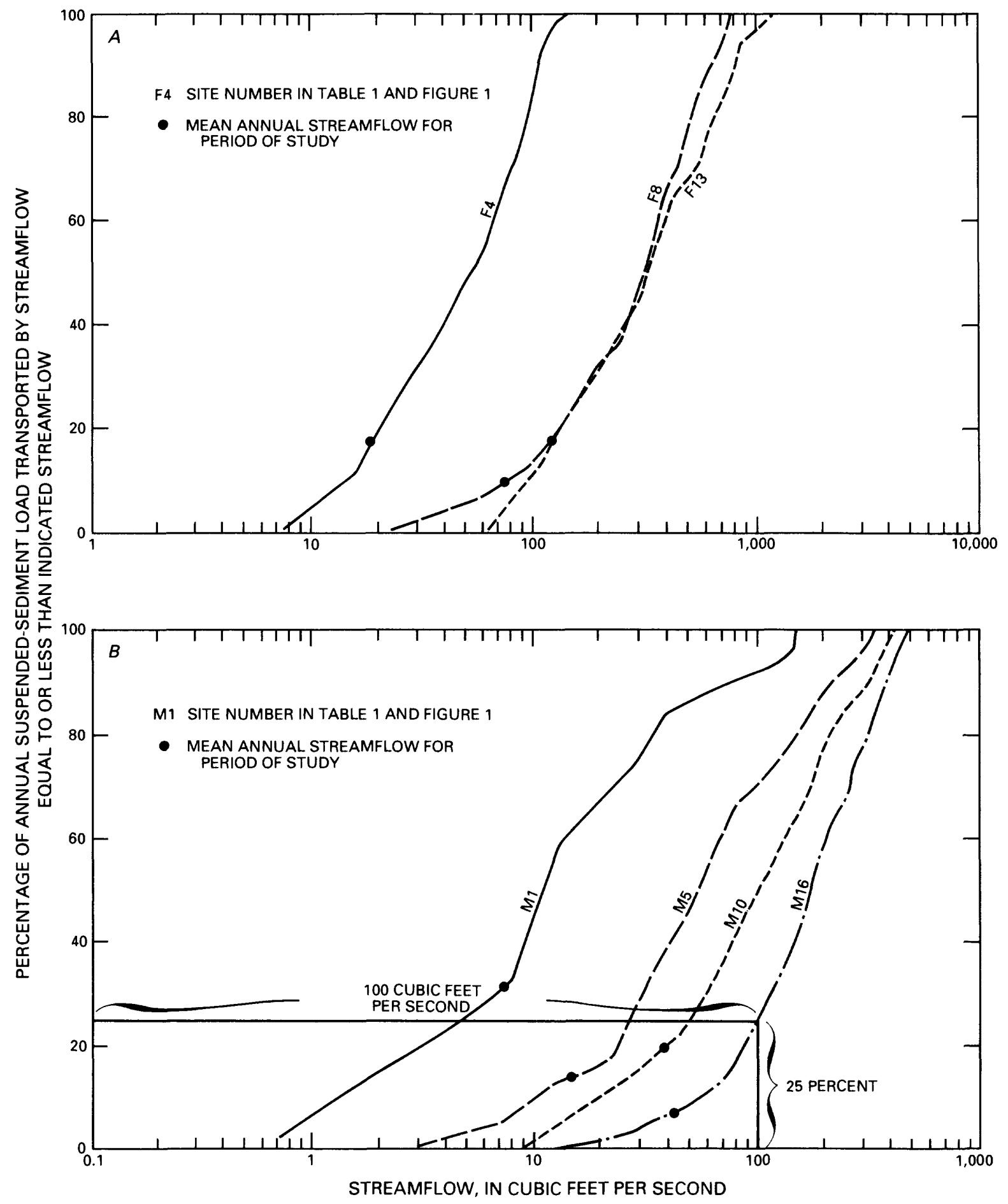

Figure 6.--Relation between percentage of annual suspended-sediment load and streamflow for suspended-sediment sampling sites on Fountain (A) and Monument (B) Creeks, water years 1985-88. 


$\frac{\text { Comparison of Suspended-Sediment Yield in Fountain and }}{\frac{\text { Monument Creeks to Suspended-Sediment Yield of }}{\text { Other Streams in Colorado }}}$

To evaluate the relative magnitude of suspended-sediment yield in Fountain and Monument Creeks, mean annual suspended-sediment yield for selected sites in Fountain and Monument Creeks were compared with mean annual suspended-sediment yield from nine other streams in Colorado (fig. 7; table 6) (Elliott and DeFeyter, 1986). Sites were selected that have established relations of suspended-sediment discharge to streamflow and that have the same periods of streamflow record (water years 1977-82). Daily streamflow data for water years 1977-82 were available for Fountain Creek near Colorado Springs (site F4), Fountain Creek at Colorado Springs (F8), Fountain Creek at Security (site F13), Monument Creek at Palmer Lake (site M1), and Monument Creek at Pikeview (site M10) (table 1; fig. 1). Suspended-sediment discharge for water years 1977-82 at sites F4, F8, F13, M1, and M10 were calculated using the regression equations listed in table 4 . These data were used to compute mean annual suspended-sediment yields in tons per square mile for each site (table 6). For the purposes of this analysis, it is assumed that the conditions that affect the relation of suspended-sediment discharge to streamflow developed for sites on Fountain and Monument Creeks for water years 1985-88 are representative of conditions during water years 1977-82. This comparison is only valid for the period of record and does not represent long-term average conditions.

The nine sites selected for comparison have drainage-basin areas that range in size from 22.1 to $550 \mathrm{mi}^{2}$, which are similar to those for sites on Fountain and Monument Creeks. General geologic, land use, and streamflow characteristics of the drainage basins for the nine comparison sites and the sites on Fountain and Monument Creeks also are listed in table 6.

For sites on Fountain and Monument Creeks, mean annual streamflow per unit area generally is less than the comparison sites (table 6). This difference may be attributed to climatic differences between the sites on Fountain and Monument Creeks and the comparison sites. There also may be larger volumes of streamflow associated with greater snowmelt runoff and transmountain diversions of streamflow in some of the drainage basins of the comparison sites.

Except for the Purgatoire River at Madrid (site 4; fig. 7; table 6), mean annual suspended-sediment yield at Fountain Creek near Colorado Springs (site F4), Fountain Creek at Colorado Springs (site F8), Fountain Creek at Security (site F13), and Monument Creek at Pikeview (site M10) were larger than the mean annual suspended-sediment yields for the comparison sites (table 6). Rainfall runoff in the study area may produce more frequent flooding than in the drainage basins upstream from the comparison sites. Rain-splash erosion, which is associated with rainfall, and greater streambank erosion in stream channels downstream from urban areas may account for the generally larger suspended-sediment yields for sites in the study area than for the comparison sites. Suspended-sediment yield at the Purgatoire River at Madrid (site 4; table 6) is affected by active streambank erosion, remnants of coal mining, and easily erodible sedimentary rocks in the drainage basin. 





Table 6.--General drainage-basin characteristics and summary of mean annual streamflow and mean annual suspended-sediment yield for selected streams in Colorado during water years 1977-82

[R, Rural; M, mining; U, urbanized]

\begin{tabular}{|c|c|c|c|c|c|c|c|c|}
\hline \multirow{3}{*}{$\begin{array}{l}\text { Site } \\
\text { number }\end{array}$} & \multirow{3}{*}{$\begin{array}{l}\text { U.S. Geological } \\
\text { Survey station } \\
\text { name and } \\
\text { station number }\end{array}$} & \multirow{3}{*}{$\begin{array}{c}\text { Elevation } \\
\text { (feet) }\end{array}$} & \multirow{3}{*}{$\begin{array}{l}\text { Drainage- } \\
\text { basin area } \\
\text { (square } \\
\text { miles) }\end{array}$} & \multirow{2}{*}{\multicolumn{3}{|c|}{$\begin{array}{c}\text { Generalized drainage-basin } \\
\text { characteristics }\end{array}$}} & \multicolumn{2}{|c|}{ Mean annual } \\
\hline & & & & & & & \multirow{2}{*}{$\begin{array}{c}\text { Streamflow } \\
\text { (acre-feet } \\
\text { per square } \\
\text { mile) }\end{array}$} & \multirow{2}{*}{$\begin{array}{l}\text { Suspended- } \\
\text { sediment yield } \\
\text { (tons per } \\
\text { square mile) }\end{array}$} \\
\hline & & & & $\begin{array}{l}\text { Surface } \\
\text { geology }\end{array}$ & $\begin{array}{l}\text { Land } \\
\text { use }\end{array}$ & $\begin{array}{l}\text { Sources of peak } \\
\text { streamflow }\end{array}$ & & \\
\hline 1 & $\begin{array}{l}\text { North Fork South } \\
\text { Platte River at } \\
\text { South Platte } \\
06707000\end{array}$ & 6,090 & 479 & Granite & $\mathbf{R}$ & Snowmelt & 368 & 32.6 \\
\hline 2 & $\begin{array}{l}\text { Saint Vrain Creek } \\
\text { at Lyons } \\
06724000\end{array}$ & 5,290 & 212 & Granite & $\mathbf{R}$ & Snowmelt & 421 & 9.6 \\
\hline 3 & $\begin{array}{l}\text { Big Thompson River } \\
\text { at Estes Park } \\
0673300\end{array}$ & 7,490 & 137 & Granite & $\mathbf{R}$ & $\begin{array}{l}\text { Snowmelt, } \\
\text { rainfall }\end{array}$ & 654 & 21.5 \\
\hline 4 & $\begin{array}{l}\text { Purgatoire River } \\
\text { at Madrid } \\
07124200\end{array}$ & 6,260 & 550 & $\begin{array}{l}\text { Sedimen- } \\
\text { tary }\end{array}$ & $R, M$ & $\begin{array}{l}\text { Snowmelt } \\
\text { rainfail }\end{array}$ & 92.9 & 747 \\
\hline 5 & $\begin{array}{l}\text { East Middle Fork } \\
\text { Parachute Creek } \\
\text { near Rio Blanco } \\
09092850\end{array}$ & 7,400 & 22.1 & $\begin{array}{l}\text { Sedimen- } \\
\text { tary }\end{array}$ & $\mathbf{R}$ & Snowmelt & 203 & 175 \\
\hline 6 & $\begin{array}{l}\text { South Fork } \\
\text { White River } \\
\text { at Buford } \\
09304000\end{array}$ & 6,970 & 170 & $\begin{array}{l}\text { Sedimen- } \\
\text { tary }\end{array}$ & $\mathbf{R}$ & Snowmelt & 987 & 173 \\
\hline 7 & $\begin{array}{l}\text { Piceance } \\
\text { Creek below } \\
\text { Rio Blanco } \\
09306007\end{array}$ & 6,370 & 177 & $\begin{array}{l}\text { Sedimen- } \\
\text { tary }\end{array}$ & $\mathbf{R}$ & $\begin{array}{l}\text { Snownelt, } \\
\text { rainfall }\end{array}$ & 48.3 & 71.0 \\
\hline 8 & $\begin{array}{l}\text { Piceance Creek } \\
\text { below Ryan } \\
\text { Gulch near } \\
\text { Rio Blanco } \\
09306200\end{array}$ & 6,070 & 506 & $\begin{array}{l}\text { Sedimen- } \\
\text { tary }\end{array}$ & $\mathbf{R}$ & $\begin{array}{l}\text { Snowmelt, } \\
\text { rainfall }\end{array}$ & 30.6 & 34.2 \\
\hline 9 & $\begin{array}{l}\text { Yellow Creek near } \\
\text { White River } \\
09306255\end{array}$ & 5,540 & 262 & $\begin{array}{l}\text { Sedimen- } \\
\text { tary }\end{array}$ & $\mathbf{R}$ & Rainfall & 5.1 & 200 \\
\hline F4 & $\begin{array}{l}\text { Fountain Creek } \\
\text { near Colorado } \\
\text { Springs } \\
07103700\end{array}$ & 6,110 & 103 & $\begin{array}{l}\text { Sedimen- } \\
\text { tary, } \\
\text { granite }\end{array}$ & $\mathbf{U}$ & $\begin{array}{l}\text { Snowmelt, } \\
\text { rainfall }\end{array}$ & 102 & 446 \\
\hline F8 & $\begin{array}{l}\text { Fountain Creek at } \\
\text { Colorado Springs, } \\
07105500\end{array}$ & 5,900 & 392 & $\begin{array}{l}\text { Sedimen- } \\
\text { tary, } \\
\text { granite }\end{array}$ & $\mathbf{U}$ & $\begin{array}{l}\text { Snowmelt, } \\
\text { rainfall }\end{array}$ & 89 & 690 \\
\hline F13 & $\begin{array}{l}\text { Fountain Creek } \\
\text { at Security } \\
07105800\end{array}$ & 5,640 & 495 & $\begin{array}{l}\text { Sedimen- } \\
\quad \text { tary, } \\
\text { granite }\end{array}$ & $\mathbf{U}$ & $\begin{array}{l}\text { Snowmelt, } \\
\text { rainfall }\end{array}$ & 119 & 429 \\
\hline M1 & $\begin{array}{l}\text { Monument Creek } \\
\text { at Palmer Lake } \\
07103747\end{array}$ & 6,950 & 25.9 & Granite & $\mathbf{R}$ & Snowmelt & 115 & 28.8 \\
\hline M10 & $\begin{array}{l}\text { Monument Creek } \\
\text { at Pikeview } \\
07104000\end{array}$ & 6,200 & 204 & $\begin{array}{l}\text { Sedimen- } \\
\quad \text { tary, } \\
\text { granite }\end{array}$ & $\mathbf{U}$ & $\begin{array}{l}\text { Snowmelt, } \\
\text { rainfall }\end{array}$ & 65.5 & 202 \\
\hline
\end{tabular}

${ }^{1}$ Single numbers indicate site numbers in figure 7 ; letters and numbers indicate site numbers in figure 1. 


\section{Bed Material and Bedload}

Information about the characterization of bed material and bedload can be used to determine the relative health of a stream habitat (Molles, 1985; Sagar, 1986). Generally, large-sized bed material and stable stream channels provide healthier environments for benthic invertebrates.

Bed material is sediment composing the streambed. Bed material may be mobile sediments, which are sampled as suspended load or bedload. Bed-material samples, collected in conjunction with bedload samples, were collected by using a hand-held, 4.6-in.-diameter scoop. The edges of the open end of the scoop were beveled. The scoop was about $10 \mathrm{in}$. 1 ong and was mounted on a $5-\mathrm{ft}$ long handle. Samples were collected by scooping perpendicular to the direction of streamflow at five or more verticals. To avoid the loss of fine material, the top 2 in. of sample were discarded before the scoop was emptied.

Bed-material samples collected in conjunction with benthic-invertebrate samples were collected from three, $1-\mathrm{ft}^{2}$ areas defined by the Surber sampler. Size distribution of bed-material samples collected in Fountain and Monument Creeks are listed in table 16 in the "Supplemental Information" section at the back of this report.

Bedload is sediment moving on or near the streambed. Bedload was collected at six periodic sampling sites (fig. 1; table 1) by using the Helley-Smith sampler with a 3- by 3-in. orifice (Helley and Smith, 1971;

Emmett, 1980). Bedload samples were collected using the single-equal-width increment method described in Edwards and Glysson (1988). At each bedloadmeasurement site, stream-channel cross sections were located as close as possible to the previously sampled cross section. Variation in the location of stream-channel cross sections was due to selection of cross sections that could be waded under existing streamflow conditions. Samples number 14 and 16 (table 7) were collected from a bridge about $0.25 \mathrm{mi}$ downstream from site F13. Bedload samples were collected periodically during snowmelt and rainfall runoff. Size distribution of bedload samples collected in Fountain and Monument Creeks are summarized in table 17 (in the "Supplemental Information" section at the back of this report).

Bedload discharge was computed by using the following equation:

$$
\mathrm{Q}_{\mathrm{bl}}=\begin{array}{lll}
\mathrm{S}_{\mathrm{w}} & \mathrm{C}_{\mathrm{w}} & 380.95
\end{array}
$$

where $\mathrm{Q}_{\mathrm{b} 1}$ = bedload discharge, in tons per day;

$\mathrm{S}_{w}=$ total sample weight, in kilograms;

$\mathrm{S}_{\mathrm{t}}=$ total sample time, in seconds;

$C_{w}=$ stream channel width, in feet; and

$380.95=$ a unit conversion constant. 
Table 7.--Results of bedload sampling for selected sediment-sampling sites on Fountain and Nonument Creeks, water years 1985-88

$[S$, snowmelt runoff; $R$, rainfall runoff; $B$, base streamflow plus sewage-treatment-plant effluent; --, no data]

\begin{tabular}{|c|c|c|c|c|c|c|c|c|}
\hline $\begin{array}{l}\text { Number of } \\
\text { bedload } \\
\text { sample in } \\
\text { figure } 8\end{array}$ & Date & $\begin{array}{l}\text { Source of } \\
\text { streamflow }\end{array}$ & $\begin{array}{l}\text { Streamflow } \\
\text { (cubic feet } \\
\text { per second) }\end{array}$ & $\begin{array}{l}\text { Stream } \\
\text { channel } \\
\text { width } \\
\text { (feet) }\end{array}$ & $\begin{array}{l}\text { Duration } \\
\text { of } \\
\text { sample } \\
\text { (seconds) }\end{array}$ & $\begin{array}{c}\text { Sample } \\
\text { weight } \\
\text { (kilograms) }\end{array}$ & $\begin{array}{l}\text { Average channel- } \\
\text { wide bedload } \\
\text { discharge } \\
\text { (tons per day per foot) }\end{array}$ & $\begin{array}{l}\text { Total-bedload } \\
\text { discharge } \\
\text { (tons per } \\
\text { day) }\end{array}$ \\
\hline \multicolumn{9}{|c|}{ FOUNTAIN CREEK NEAR COLORADO SPRINGS (SITE F4) } \\
\hline $\begin{array}{l}1 \\
2 \\
3 \\
4\end{array}$ & $\begin{array}{l}04-04-85 \\
04-18-85 \\
04-30-85 \\
04-29-87\end{array}$ & $\begin{array}{l}\mathbf{S} \\
\mathbf{S} \\
\mathbf{R} \\
\mathbf{S}\end{array}$ & $\begin{array}{r}22 \\
35 \\
122 \\
24\end{array}$ & $\begin{array}{l}17.0 \\
19.8 \\
22.6 \\
17.5\end{array}$ & $\begin{array}{r}960 \\
1,440 \\
1,220 \\
1,020\end{array}$ & $\begin{array}{l}0.77 \\
3.37 \\
12.8 \\
1.80\end{array}$ & $\begin{array}{r}0.31 \\
.89 \\
4.00 \\
.67\end{array}$ & $\begin{array}{r}5.2 \\
17.6 \\
90.3 \\
11.8\end{array}$ \\
\hline \multicolumn{9}{|c|}{ FOUNTAIN CREEK AT COLORADO SPRINGS (SITE F8) } \\
\hline $\begin{array}{l}5 \\
6 \\
7 \\
8 \\
9\end{array}$ & $\begin{array}{l}04-04-85 \\
05-03-85 \\
05-01-87 \\
06-23-88 \\
06-23-88\end{array}$ & $\begin{array}{l}\mathbf{S} \\
\mathbf{S} \\
\mathbf{S} \\
\mathbf{R} \\
\mathbf{R}\end{array}$ & $\begin{array}{r}115 \\
526 \\
131 \\
115 \\
90\end{array}$ & $\begin{array}{c}57.5 \\
119 \\
57.0 \\
26.0 \\
25.0\end{array}$ & $\begin{array}{r}1,260 \\
1,500 \\
1,560 \\
900 \\
900\end{array}$ & $\begin{array}{l}13.3 \\
43.3 \\
30.8 \\
19.7 \\
21.1\end{array}$ & $\begin{array}{c}4.02 \\
11.0 \\
7.52 \\
8.34 \\
8.93\end{array}$ & $\begin{array}{r}231 \\
1,310 \\
429 \\
217 \\
223\end{array}$ \\
\hline \multicolumn{9}{|c|}{ FOUNTAIN CREEK AT SECURITY (SITE F13) } \\
\hline \multirow[t]{2}{*}{$\begin{array}{l}10 \\
11 \\
12 \\
13 \\
14 \\
15 \\
16\end{array}$} & $\begin{array}{l}04-04-85 \\
05-03-85 \\
10-28-85 \\
05-01-87 \\
08-26-87 \\
06-15-88 \\
08-09-88\end{array}$ & $\begin{array}{l}\mathbf{S} \\
\mathbf{S} \\
\mathbf{B} \\
\mathbf{S} \\
\mathbf{R} \\
\mathbf{R} \\
\mathbf{R}\end{array}$ & $\begin{array}{r}197 \\
633 \\
123 \\
170 \\
1,190 \\
130 \\
1,000\end{array}$ & $\begin{array}{l}53.0 \\
111 \\
68.5 \\
82.5 \\
115 \\
51.5 \\
127\end{array}$ & $\begin{array}{r}1,080 \\
1,260 \\
1,320 \\
1,560 \\
330 \\
1,560 \\
345\end{array}$ & $\begin{array}{l}17.2 \\
29.4 \\
14.2 \\
21.9 \\
26.9 \\
10.3 \\
16.9\end{array}$ & $\begin{array}{c}6.06 \\
8.88 \\
4.09 \\
5.34 \\
31.0 \\
2.51 \\
18.7\end{array}$ & $\begin{array}{r}322 \\
987 \\
281 \\
441 \\
3,570 \\
130 \\
2,370\end{array}$ \\
\hline & \multicolumn{8}{|c|}{ MONUMENT CREEK ABOVE NORTH GATE BOULEVARD AT U.S. AIR } \\
\hline \multirow[t]{2}{*}{$\begin{array}{l}17 \\
18 \\
19\end{array}$} & $\begin{array}{l}04-18-85 \\
05-03-85 \\
04-30-87\end{array}$ & $\begin{array}{l}\mathbf{S} \\
\mathbf{S} \\
\mathbf{S}\end{array}$ & $\begin{array}{r}62 \\
199 \\
33\end{array}$ & $\begin{array}{l}15.0 \\
35.0 \\
16.4\end{array}$ & $\begin{array}{r}1,140 \\
1,320 \\
900\end{array}$ & $\begin{array}{l}18.1 \\
68.8 \\
0.38\end{array}$ & $\begin{array}{c}6.05 \\
19.8 \\
0.16\end{array}$ & $\begin{array}{l}90.7 \\
695 \\
2.6\end{array}$ \\
\hline & \multicolumn{8}{|c|}{ MONUMENT CREEK AT PIKEVIEW (SITE M10) } \\
\hline $\begin{array}{l}20 \\
21 \\
22\end{array}$ & $\begin{array}{l}04-03-85 \\
05-02-85 \\
04-29-87\end{array}$ & $\begin{array}{l}\mathbf{S} \\
\mathbf{S} \\
\mathbf{S}\end{array}$ & $\begin{array}{r}57 \\
321 \\
72\end{array}$ & $\begin{array}{l}55.5 \\
76.0 \\
54.5\end{array}$ & $\begin{array}{l}1,080 \\
1,080 \\
1,500\end{array}$ & $\begin{array}{r}4.0 \\
31.3 \\
20.1\end{array}$ & $\begin{array}{l}1.41 \\
11.0 \\
5.10\end{array}$ & $\begin{array}{l}78.3 \\
839 \\
278\end{array}$ \\
\hline \multicolumn{9}{|c|}{ MONUMENT CREEK AT BIJOU STREET AT COLORADO SPRINGS (SITE M16) } \\
\hline $\begin{array}{l}23 \\
24 \\
25\end{array}$ & $\begin{array}{l}04-03-85 \\
05-02-85 \\
04-30-87\end{array}$ & $\begin{array}{l}\mathbf{S} \\
\mathbf{S} \\
\mathbf{S}\end{array}$ & $\begin{array}{r}58 \\
346 \\
77\end{array}$ & $\begin{array}{l}32.0 \\
70.0 \\
35.5\end{array}$ & $\begin{array}{r}900 \\
1,380 \\
960\end{array}$ & $\begin{array}{l}15.4 \\
41.6 \\
13.7\end{array}$ & $\begin{array}{l}6.52 \\
11.5 \\
5.44\end{array}$ & $\begin{array}{l}209 \\
804 \\
193\end{array}$ \\
\hline
\end{tabular}


Table 7.--Results of bedload sampling for selected sediment-sampling sites on Fountain and Nonument Creeks, water years 1985-88--Continued

\begin{tabular}{|c|c|c|c|c|c|}
\hline $\begin{array}{l}\text { Number of } \\
\text { bedload } \\
\text { sample in } \\
\text { figure } 8\end{array}$ & $\begin{array}{c}\text { Suspended- } \\
\text { sediment } \\
\text { concentration } \\
\text { (milligrams per liter) }\end{array}$ & $\begin{array}{c}\text { Suspended- } \\
\text { sediment } \\
\text { discharge } \\
\text { (tons per day) }\end{array}$ & $\begin{array}{c}\text { Total } \\
\text { sediment } \\
\text { discharge } \\
\text { (tons per day) }\end{array}$ & $\begin{array}{l}\text { Total sediment } \\
\text { discharge, } \\
\text { Colby's method } \\
\text { (tons per day) }\end{array}$ & $\begin{array}{c}\text { Bedload discharge as a } \\
\text { percentage of total } \\
\text { sediment discharge } \\
\text { (percent) }\end{array}$ \\
\hline
\end{tabular}

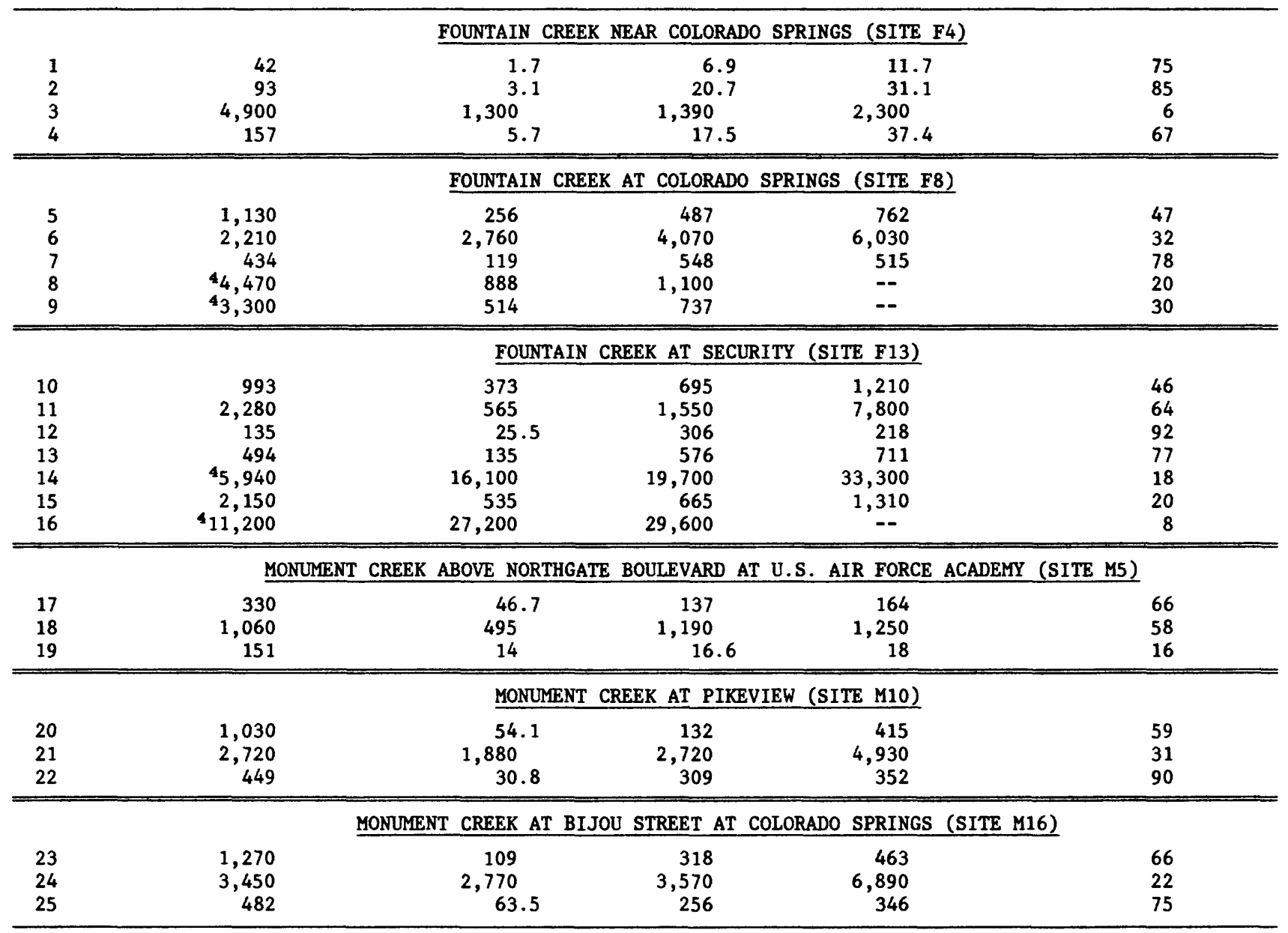

${ }^{1}$ Suspended-sediment discharge adjusted by computing percentage of streamflow sampled using methods described in Colby and Hubbell (1961).

${ }^{2}$ Total sediment discharge based on the sum of the measured bedload discharge and adjusted suspendedsediment discharge.

${ }^{3}$ Colby, 1957 .

The bedload sample was collected during a period of rapidly falling streamflow. Suspended-sediment concentration is a mean of suspended-sediment concentrations collected before and after the bedload sample was collected. 
Definitions of grain-size classifications used for bed-material and bedload samples are discussed in Guy (1969). The median grain size of bedmaterial samples collected in conjunction with bedload samples was very coarse sand (in the range of 1.0 to $2.0 \mathrm{~mm}$ ) to very coarse gravel (in the range of 32.0 to $64.0 \mathrm{~mm}$ ). Median grain size of bed material sampled in conjunction with benthic-invertebrate samples was very coarse sand (in the range of 1.0 to $2.0 \mathrm{~mm}$ ) to small cobbles (in the range of 64 to $128 \mathrm{~mm}$ ) (table 16 in the "Supplemental Information" section at the back of this report). The median grain size of all bedload samples was coarse sand (in the range of 0.50 to $1.0 \mathrm{~mm}$ ) to very fine gravel (in the range of 2.0 to $4.0 \mathrm{~mm}$ ) (table 17 , in the "Supplemental Information" section at the back of this report).

The median $\mathrm{d}_{50}$ of bed-material and bedload samples is summarized in table 8. The difference in median $d_{50}$ between the two sets of bed-material samples is a result of the collection of bed-material samples at bedload and benthic-invertebrate sampling sites. The most desirable site for collecting bedload samples is at uniform stream cross sections that have bed material with a uniform distribution of sediment grain sizes. When bed material is homogeneous, "perching" of the bedload sampler on large gravel and cobbles is avoided, and the loss of bedload sample transported under the sampler is minimized. Benthic-invertebrate sampling sites were selected to represent the variation in benthic invertebrates associated with existing bed-material conditions, which at most sites tended to include coarse gravel to cobbles. Size distribution of bed material is determined by calculating the percent of the total sample weight for each size class represented. Collection of only one or two grains of coarser bed material may skew the size distribution of samples collected in heterogenous bed material. Bed-material samples collected in conjunction with benthic invertebrates were collected where bed material was heterogenous, unlike the homogenous bed-material conditions desired for bedload sampling. Because of these sampling-site selection criteria, with the exception of Monument Creek at Pikeview (site M10), where bed material is mostly sand to very fine gravel (table 16 in the "Supplemental Information" section at the back of this report), bed-material samples collected in conjunction with benthic-invertebrate samples included a larger percentage of coarse grain sizes than those collected in conjunction with bedload samples (table 16).

Table 8.--Median grain-size statistics for bed-material and bedload samples for selected sites on Fountain and Monument Creeks, water years 1985-88

[d $\mathrm{d}_{50}$, median grain size; --, not applicable]

\begin{tabular}{ccccc}
\hline Site & U.S. Geo- & \multicolumn{2}{c}{ Median $\mathrm{d}_{50}$, in millimeters } & \\
\cline { 3 - 3 } $\begin{array}{c}\text { number } \\
\text { in } \\
\text { figure } \\
\text { logical }\end{array}$ & $\begin{array}{l}\text { Survey } \\
\text { station } \\
\text { number }\end{array}$ & $\begin{array}{c}\text { Sampled in conjunction } \\
\text { with bedload samples }\end{array}$ & $\begin{array}{c}\text { Sampled in conjunction } \\
\text { with benthic-invertebrate } \\
\text { samples }\end{array}$ & $\begin{array}{c}\text { Bedload } \\
\text { samples }\end{array}$ \\
\hline F4 & 07103700 & 3.29 & 51.0 & \\
F8 & 07105500 & 2.57 & 40.0 & 1.71 \\
F13 & 07105800 & 2.33 & 12.0 & 1.52 \\
M5 & 07103780 & 6.23 & 60.0 & 1.35 \\
M10 & 07104000 & 1.93 & 1.83 & 1.43 \\
M16 & 07104905 & 1.96 & - & 1.76 \\
\hline
\end{tabular}


Results of bedload sampling listed in table 17 (in the "Supplemental Information" section at the back of this report) are summarized in table 7 . To evaluate the relative magnitude of bedload discharge measured at sites on Fountain and Monument Creeks, bedload discharge was calculated as a percentage of total sediment discharge for all bedload samples collected (table 7).

Total sediment discharge was determined by using two methods. The first method is the sum of measured bedload discharge and adjusted suspendedsediment discharge. Computations of suspended-sediment discharge account for some of the suspended-sediment discharge in the unsampled zone. The unsampled zone can be described as follows:

Sampling the entire depth of the water column is not possible because the location of the suspended-sediment sampler nozzle relative to the bottom of the sampler prevents the nozzle from passing through the zone (unsampled zone) close to the streambed (Edwards and Glysson, 1988, p. 3).

In order to avoid the inherent bias that suspended-sediment discharge computations would contribute to the calculation of total sediment discharge, adjusted suspended-sediment discharges were computed based on the percentage of streamflow sampled. Percentage of streamflow sampled was determined using methods described in Colby and Hubbell (1961).

The second method for determining total sediment discharge was developed by Colby (1957). Colby's method is used to calculate total sediment discharge by relating unmeasured sediment discharge to mean velocity and to concentration of measured suspended sediment. Total sediment discharge calculated using Colby's method usually was larger than measured total sediment discharge. Results from the two methods are compared in table 7 for sites where bedload discharge was measured.

Studies of sediment transport in the Big Lost River, Idaho, Big Sandy River, Wyoming, and the Yampa River, Colorado, have indicated that bedload discharge as a percentage of total sediment discharge ranged from about 1.0 to about 83 percent (Kircher, 1982; Elliott and others, 1984; Williams and Krupin, 1984). A similar range in percentage (6 to 92) occurs at bedload sampling sites on Fountain and Monument Creeks.

Except for one bedload measurement sample (number 12, table 7), bedload discharge measurements represent snowmelt or rainfall-runoff conditions. Bedload sample number 12 (table 7) represents streamflow conditions where about one-half of the streamflow discharge was base streamflow and the remainder was sewage-treatment-plant effluent. Bedload discharge as a percentage of total sediment discharge usually was smallest during rainfall runoff and ranged from 6 to 30 percent (fig. 8; table 7). During rainfall runoff, fine sediments are introduced into streams by erosion resulting from rain splash and surface runoff; fine sediments also are suspended from the streambed. When supply of fine sediments is limited, bedload discharge increases as a percentage of total sediment discharge. Bedload discharge, as a percentage of total sediment discharge during snowmelt runoff, ranged from 16 to 90 percent ( $\mathrm{fig} .8$; table 7 ). This variation is a result of the natural variability of bedload transport and the variability of the supply of fine sediments for transport as suspended sediment. Bedload samples 6, 19, 21, and 24 have the smallest bedload discharge as a percentage of total sediment 
discharge for samples collected during snowmelt runoff (fig. 8; table 7). The small total bedload discharge for sample 19 (2.6 tons/d) may be a result of a lack of sand-sized particles available for transport (table 16 in the "Supplemental Information" section at the back of this report). Bedload-sample numbers 6,21 , and 24 were collected near the peak discharge of the snowmelt runoff when fine sediments from the stream channel were readily available for transport as suspended sediment. The remaining samples that have a larger bedload discharge as a percentage of total sediment discharge were collected after the snowmelt-runoff peak and represent sediment-transport conditions where fine sediments have been flushed out of the stream channel and where there is no contribution of fine sediments from streams tributary to Fountain Creek.

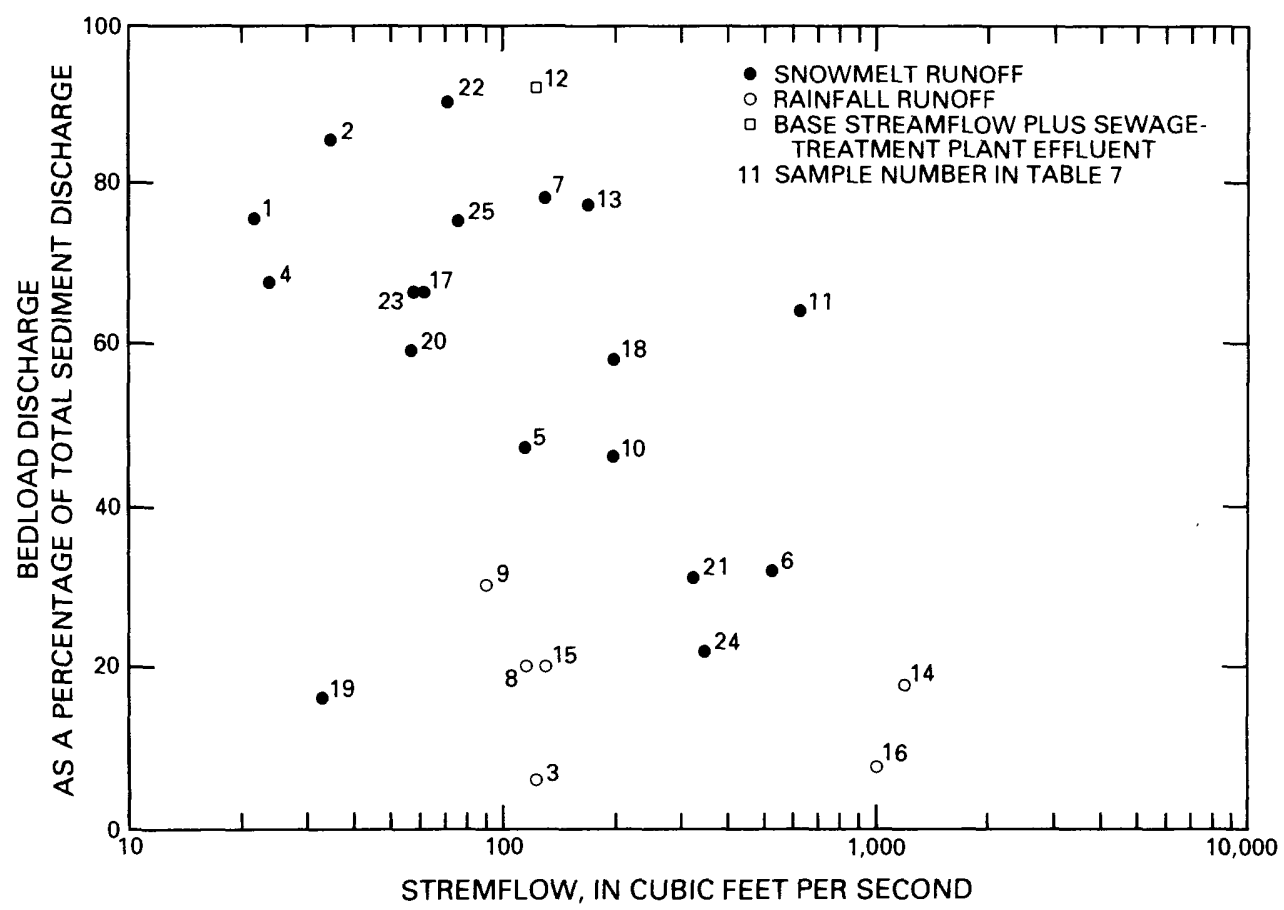

Figure 8.--Relation of streamflow and bedload discharge as a percentage of total sediment discharge for bedload-sampling sites on Fountain and Monument Creeks.

The competence of streamflow can be described by using the Shields (1936) dimensionless shear-stress relation for estimating the particle size of bed material at the threshold of movement. Maximum particle size of bed material transportable for various streamflows was estimated by using the following equation (E1liott and others, 1984):

$$
d_{c}=\frac{D s}{\left(\gamma_{s / \gamma}-1\right) \tau_{*}}(304.8)
$$

where $\mathrm{d}_{\mathrm{c}}=$ particle size of bed material, in millimeters, at threshold of movement; 


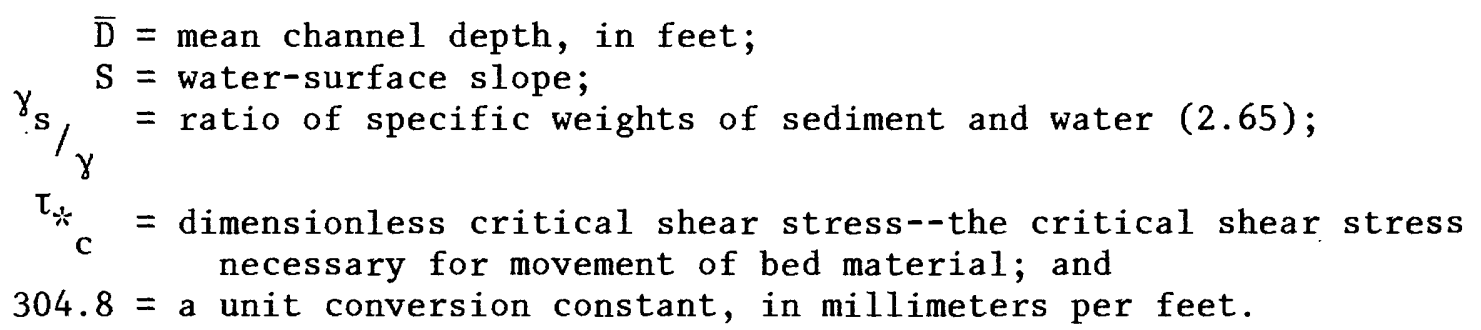

The large quantities of bedload transported by Fountain and Monument Creeks (table 7) are indicative of streamflow conditions during which the critical shear stress necessary for bed-material movement (competence) is normally met or exceeded. Entrainment of gravel and cobbles in natural streams usually is estimated by using values of $\tau_{*}$ that range from 0.045 to 0.060 (Andrews, 1983). Ranges of sediment-particle sizes at threshold of movement, computed by using $\tau_{*}$ of 0.045 and 0.060 , for selected sedimentsampling sites on Fountain and ${ }^{c}$ Monument Creeks are summarized in table 9 . The particle size of bed material at the threshold of movement, $d$, is much larger than the $d_{50}$ of most of the bed-material samples collected in conjunction with stream channel depth and water-surface slope measurements (these samples were collected at cross sections where bedload discharge was measured) (table 9). Comparison of $d$ with the median $d_{50}$ of bed-material samples collected in conjunction with benthic-invertebrate samples (table 8 ) indicates that $d$ usually is much larger than $d_{50}$ at Fountain Creek at Security (site F13) ${ }^{c}$ and Monument Creek at Pikeview (site M10). The median $\mathrm{d}_{50}$ of bed-material samples collected in conjunction with benthic-invertebrate samples at Fountain Creek near Colorado Springs (site F4), Fountain Creek at Colorado Springs (site F8), and Monument Creek at USAFA (site M5) usually were larger than $\mathrm{d}_{\mathrm{c}}$.

The range of particle sizes at threshold of movement listed in table 9 represent conditions associated with small to moderate streamflows. The upper limit of particle sizes at threshold of movement would be larger for higher streamflows. For example, a peak streamflow of $2,400 \mathrm{ft}^{3} / \mathrm{s}$ and a mean channel depth of $2.52 \mathrm{ft}$ and a water-surface slope of 0.006 was recorded for a flood that occurred June 1, 1977, at Fountain Creek at Colorado Springs (site F8). Particle sizes at threshold of movement $\left(d_{c}\right)$ for dimensionless critical shear stresses $\left(\tau_{*}\right.$ ) of 0.45 and 0.60 were 62.1 and $46.5 \mathrm{~mm}$. These values of $d_{c}$ $c$

exceed the median $d_{50}$ of bed-material samples collected at site $F 8$ in conjunction with bedload and benthic-invertebrate samples (table 8). This analysis indicates that Fountain and Monument Creeks are capable of transporting most of the bed-material grain sizes sampled (table 9, and table 16 in the "Supplemental Information" section at the back of this report).

\section{Stream-Channel Cross Sections}

Changes in streambed elevation in Fountain and Monument Creeks were determined semiquantitatively by monitoring a network of stream-channel cross sections. Stream-channel cross sections, hereinafter referred to as cross sections, were located at Fountain Creek near Colorado Springs (site F4), Fountain Creek at Colorado Springs (site F8), Fountain Creek at Security (site F13), Monument Creek at USAFA (site M5), and Monument Creek at Pikeview (site M10) (fig. 1; table 1). 
Table 9.--Summary of calculations for sediment-particle sizes at threshold of movement

$[--$, indicates no data]

\begin{tabular}{|c|c|c|c|c|c|c|c|}
\hline \multirow[t]{3}{*}{ Date } & \multirow{3}{*}{$\begin{array}{l}\text { Streamflow } \\
\text { (cubic feet } \\
\text { per second) }\end{array}$} & \multirow{3}{*}{$\begin{array}{l}\text { Mean } \\
\text { channel } \\
\text { depth } \\
\text { (feet) }\end{array}$} & \multirow{3}{*}{$\begin{array}{c}\text { Water- } \\
\text { surface } \\
\text { slope } \\
\text { (feet } \\
\text { per feet) }\end{array}$} & \multirow{3}{*}{\multicolumn{2}{|c|}{ 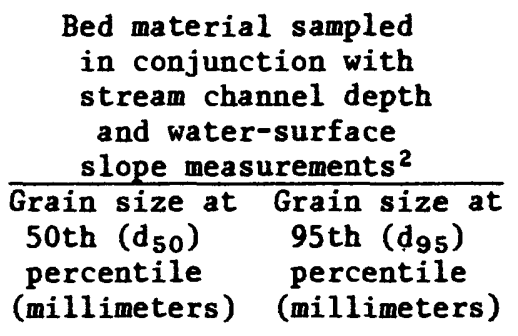 }} & \multirow{2}{*}{\multicolumn{2}{|c|}{$\begin{array}{l}\text { Particle size of } \\
\text { bed material (d ) at } \\
\text { threshold of movement } \\
\text { for dimensionless } \\
\text { critical shear stress } \\
\text { (millimeters) }\end{array}$}} \\
\hline & & & & & & & \\
\hline & & & & & & $\tau_{*}=0.04:$ & $\tau_{*}=0.060$ \\
\hline \multicolumn{8}{|c|}{ FOUNTAIN CREEK NEAR COLORADO SPRINGS (SITE F4) } \\
\hline $\begin{array}{l}04-30-85 \\
04-29-87\end{array}$ & $\begin{array}{r}122 \\
24\end{array}$ & $\begin{array}{r}1.29 \\
.61\end{array}$ & $\begin{array}{l}0.01 \\
.008\end{array}$ & $\begin{array}{l}2.9 \\
2.1\end{array}$ & $\begin{array}{l}29.0 \\
10.8\end{array}$ & $\begin{array}{l}53.0 \\
20.0\end{array}$ & $\begin{array}{l}39.7 \\
15.0\end{array}$ \\
\hline \multicolumn{8}{|c|}{ FOUNTAIN CREEK AT COLORADO SPRINGS (SITE F8) } \\
\hline $\begin{array}{l}05-03-85 \\
05-01-87 \\
06-23-88\end{array}$ & $\begin{array}{r}526 \\
131 \\
3102\end{array}$ & $\begin{array}{r}1.10 \\
.73 \\
4.60\end{array}$ & $\begin{array}{l}.003 \\
.006 \\
.006\end{array}$ & $\begin{array}{l}3.4 \\
2.6 \\
2.9\end{array}$ & $\begin{array}{r}34.0 \\
107.0 \\
14.2\end{array}$ & $\begin{array}{l}13.5 \\
18.0 \\
14.8\end{array}$ & $\begin{array}{l}10.2 \\
13.5 \\
11.1\end{array}$ \\
\hline \multicolumn{8}{|c|}{ FOUNTAIN CREEK AT SECURITY (SITE F13) } \\
\hline $\begin{array}{l}05-03-85 \\
10-28-85 \\
05-01-87 \\
06-15-88\end{array}$ & $\begin{array}{l}633 \\
123 \\
170 \\
150\end{array}$ & $\begin{array}{r}1.23 \\
.62 \\
.64 \\
.89\end{array}$ & $\begin{array}{l}.011 \\
.010 \\
.007 \\
.003\end{array}$ & $\begin{array}{l}2.1 \\
2.5 \\
1.8 \\
--\end{array}$ & $\begin{array}{c}24.8 \\
35.7 \\
8.2 \\
--\end{array}$ & $\begin{array}{l}55.5 \\
25.4 \\
18.4 \\
11.0\end{array}$ & $\begin{array}{r}41.6 \\
19.1 \\
13.8 \\
8.2\end{array}$ \\
\hline \multicolumn{8}{|c|}{ MONUMENT CREEK ABOVE NORTH GATE BOULEVARD AT U.S. AIR FORCE ACADEMY (SITE M5) } \\
\hline $\begin{array}{l}04-18-85 \\
05-03-85 \\
04-30-87\end{array}$ & $\begin{array}{r}62 \\
199 \\
33\end{array}$ & $\begin{array}{r}1.23 \\
1.40 \\
.91\end{array}$ & $\begin{array}{l}.005 \\
.004 \\
.006\end{array}$ & $\begin{array}{r}6.2 \\
2.7 \\
52.7\end{array}$ & $\begin{array}{r}29.5 \\
15.4 \\
119.6\end{array}$ & $\begin{array}{l}25.2 \\
23.0 \\
22.4\end{array}$ & $\begin{array}{l}18.9 \\
17.2 \\
16.8\end{array}$ \\
\hline \multicolumn{8}{|c|}{ MONUMENT CREEK AT PIKEVIEW (SITE M10) } \\
\hline $\begin{array}{l}10-28-85 \\
04-29-87\end{array}$ & $\begin{array}{l}24.3 \\
72\end{array}$ & $\begin{array}{r}0.25 \\
.44\end{array}$ & $\begin{array}{r}0.020 \\
.015\end{array}$ & $\begin{array}{l}1.5 \\
2.5\end{array}$ & $\begin{array}{r}6.0 \\
13.0\end{array}$ & $\begin{array}{l}20.5 \\
27.1\end{array}$ & $\begin{array}{l}15.4 \\
20.3\end{array}$ \\
\hline \multicolumn{8}{|c|}{ MONUMENT CREEK AT BIJOU STREET AT COLORADO SPRINGS (SITE M16) } \\
\hline $\begin{array}{l}05-02-85 \\
04-30-87\end{array}$ & $\begin{array}{r}346 \\
77\end{array}$ & $\begin{array}{r}1.12 \\
.64\end{array}$ & $\begin{array}{l}.010 \\
.006\end{array}$ & $\begin{array}{l}1.9 \\
1.5\end{array}$ & $\begin{array}{r}23.8 \\
9.0\end{array}$ & $\begin{array}{l}46.0 \\
15.8\end{array}$ & $\begin{array}{l}34.5 \\
11.8\end{array}$ \\
\hline
\end{tabular}

${ }^{1}$ Water-surface slope was measured by a transit survey of water-surface elevations.

${ }^{2}$ Bed-material samples were collected at cross sections where bedload discharge was measured.

${ }^{3}$ Average of two streamflow measurements made in conjunction with bedload sampling (table 7 ).

${ }^{4}$ Estimated. 
Cross sections were established in the vicinity of streamflow-gaging stations and were referenced to the local stream-gage datum or an arbitrary datum. Surveys of the cross sections were done periodically, usually in conjunction with benthic-invertebrate sampling. Cross-section data are summarized in table 18 in the "Supplemental Information" section at the back of this report.

\section{Fountain Creek}

The cross section at site $\mathrm{F} 4$ was established about $200 \mathrm{ft}$ upstream from the stream gage. Cross-section measurements made at site F4 indicate little or no measured change in streambed elevation (fig. 16 and table 18 in the "Supplemental Information" section at the back of this report).

Two cross sections were established at site F8, one about $200 \mathrm{ft}$ upstream from the stream gage and the other about $300 \mathrm{ft}$ downstream from the stream gage. The two cross sections at site F8 are depicted in figures 17 and 18 in the "Supplemental Information" section at the back of this report. Maximum measured changes in streambed elevation between consecutive cross-section surveys was -0.8 (October 29, 1985, to April 14, 1986, cross-section stations 34.0 and 40.0) and $1.9 \mathrm{ft}$ (August 12, 1985, to October 29, 1985, cross-section station 105.0) at the upstream cross section and -1.4 (July 10, 1986, to August 25, 1986, cross-section station 20.0) and $1.4 \mathrm{ft}$ (August 25, 1986, to November 7,1986 , cross section station 20.0) at the downstream cross section (table 18 in the "Supplemental Information" section at the back of this report). The streambed at site $\mathrm{F} 8$ is mobile, and bedload transport occurs during most streamflows (tables 7 and 9 ).

The cross section at site F13 is located about $200 \mathrm{ft}$ upstream from the stream gage. Maximum measured changes in streambed elevation between consecutive cross-section surveys was -1.1 (July 11,1985 , to July 23, 1985, cross-section stations 40.0 and 100.0) and $1.4 \mathrm{ft}$ (July 11, 1985, to July 23, 1985 , cross-section station 25.5) (table 18 in the "Supplemental Information" section at the back of this report). The streambed at site F13 is mobile during most streamflow conditions. A series of cross-section surveys made at site F13 from January 11, 1985, through October 29, 1985, illustrates how streambed elevations may fluctuate in stream reaches that have a mobile streambed (fig. 9).

\section{Monument Creek}

The cross section at site M5 is located about $100 \mathrm{ft}$ downstream from the stream gage. Cross-section measurements made at site M5 indicate little or no measured change in streambed elevation in the stream channel (fig. 19 in the "Supplemental Information" section at the back of this report; table 18).

The cross section at site $\mathrm{M} 10$ is located about $100 \mathrm{ft}$ downstream from the stream gage. Examples of the cross section are shown in figure 20 in the "Supplemental Information" section at the back of this report. The cross sections depicted in figure 20 are for stations 92.0 through $172.0 \mathrm{ft}$ (table 18). The entire cross section is about $172.0 \mathrm{ft}$ wide; however, the active stream channel having perennial streamflow is only about $80.0 \mathrm{ft}$ wide. Maximum measured changes in streambed elevation between consecutive crosssection surveys was $-1.8 \mathrm{ft}$ (April 29, 1987, to July 14, 1987, cross section station 66.0) and $1.2 \mathrm{ft}$ (July 14, 1987, to August 27, 1987, cross section station 66.0) (table 18). The streambed is mobile, and changes in streambed elevation occur during most streamflows. 


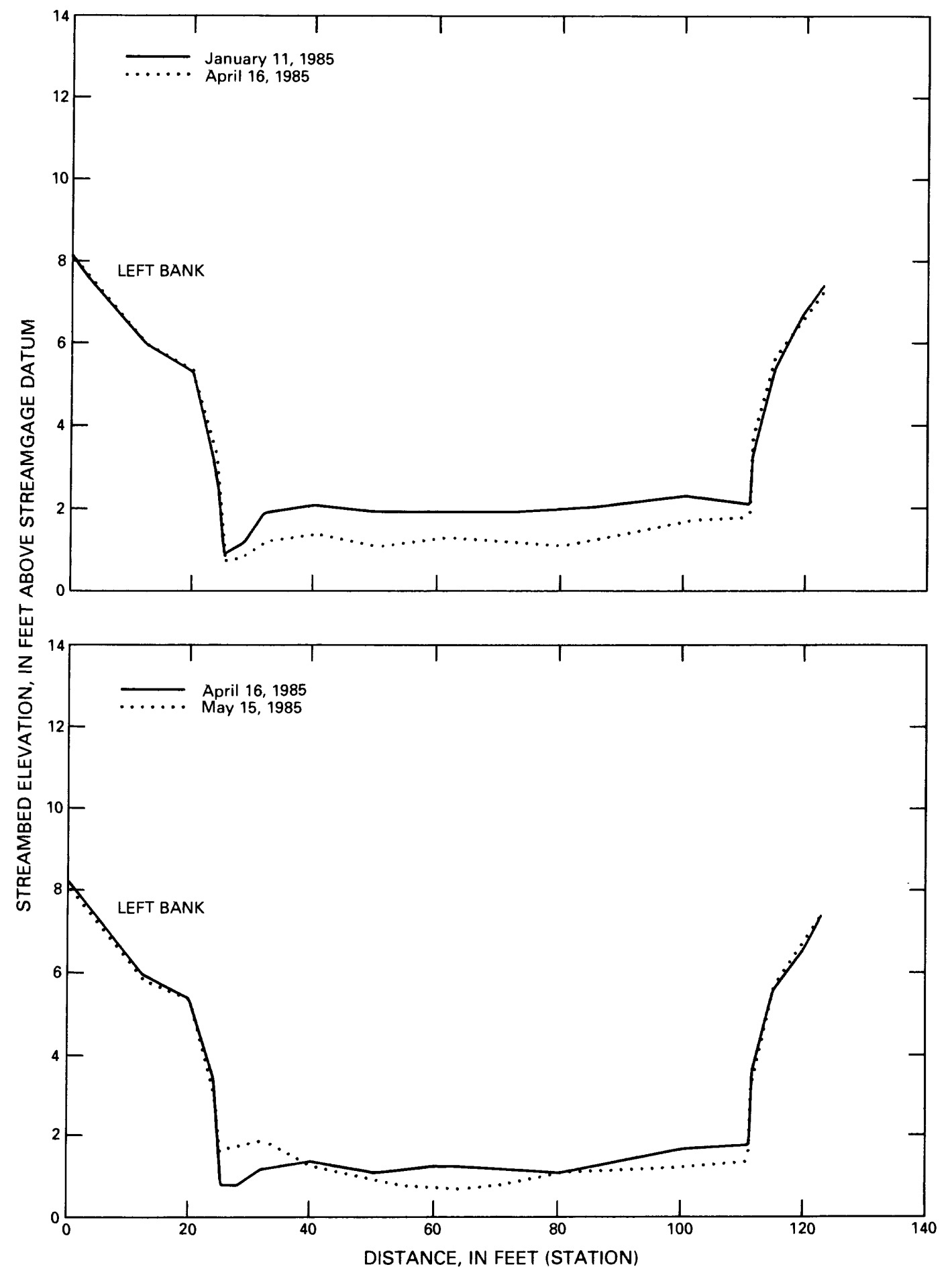

Figure 9.--Selected stream-channel cross-section surveys for Fountain Creek at Security (site F13). 


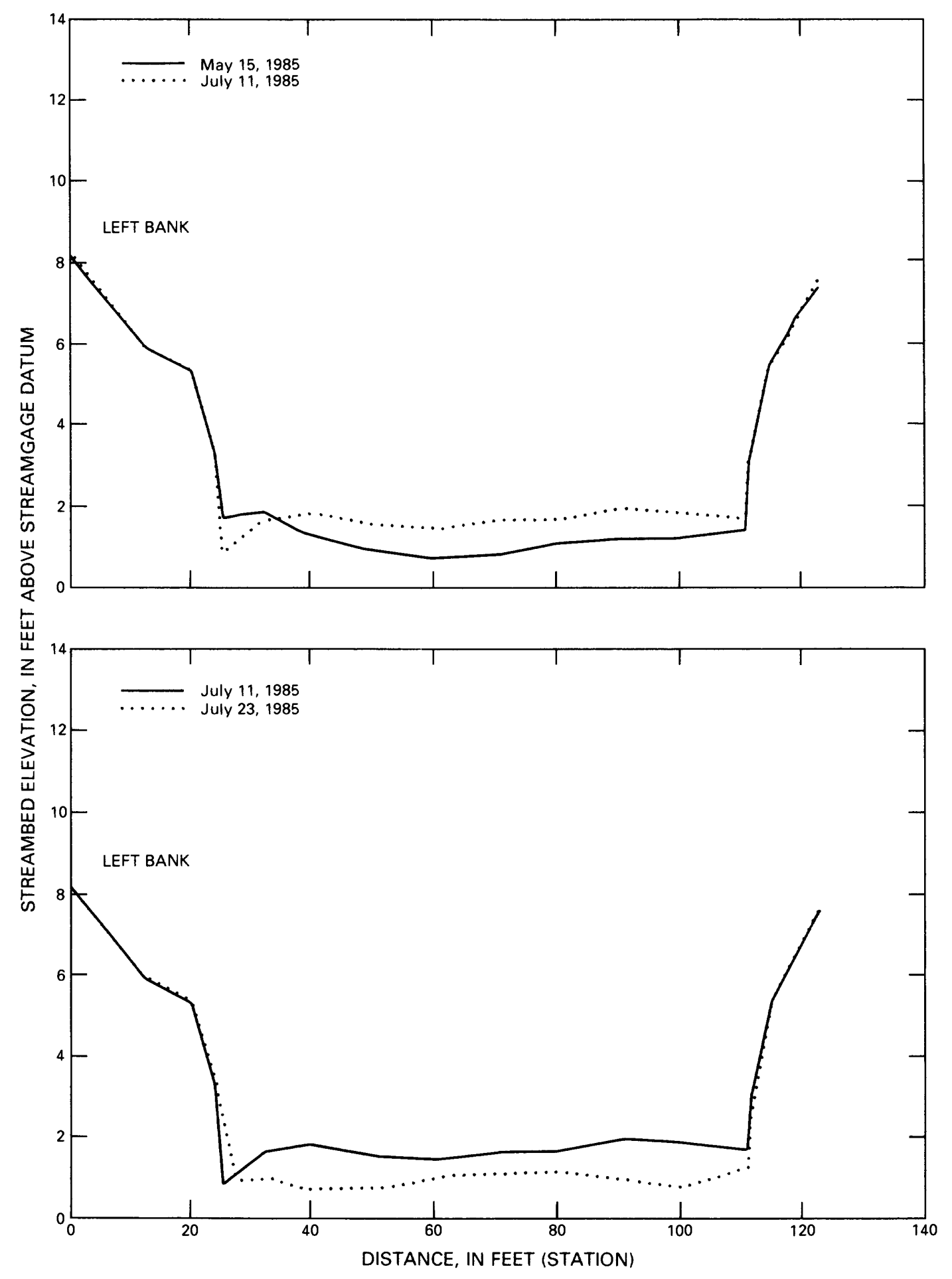

Figure 9.--Selected stream-channel cross-section surveys for Fountain Creek at Security (site F13)--Continued. 


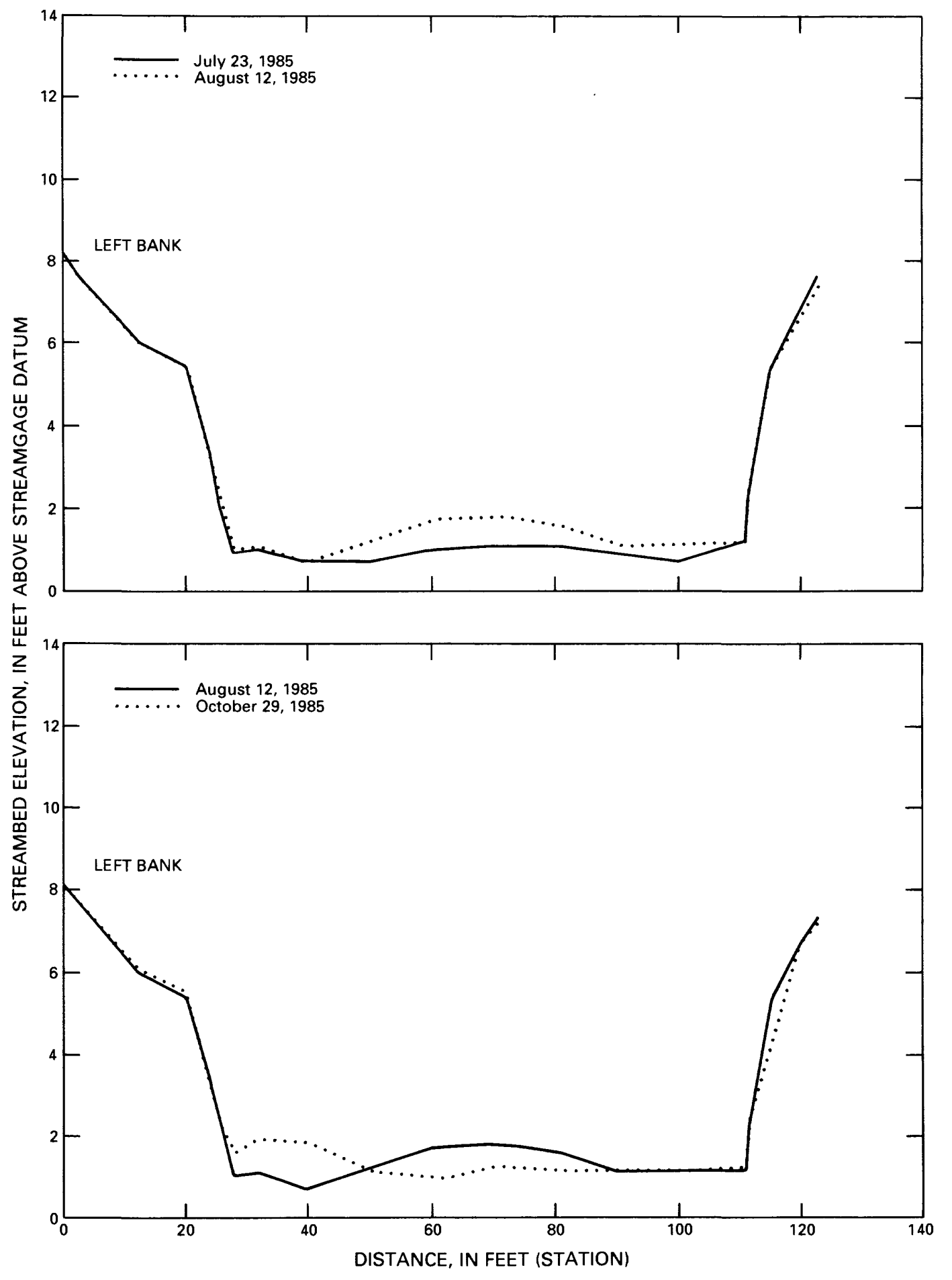

Figure 9.--Selected stream-channel cross-section surveys for Fountain Creek at Security (site F13)--Continued. 


\section{BENTHIC INVERTEBRATES}

The annual streamflow regime and the transport of sediment in a stream environment can affect the occurrence and abundance of stream biota (Canton and others, 1984; Molles, 1985; Meffe and Minckley, 1986; Sagar, 1986). The following is a discussion of the temporal and spatial occurrence of benthic invertebrates at five selected sites on Fountain and Monument Creeks (fig. 1, table 1).

\section{Sampling Methods and Sampling-Site Descriptions}

Benthic-invertebrate samples were collected at sites that represent a variety of hydrologic, water quality, and stream-habitat conditions. All sampling sites were located at U.S. Geological Survey streamflow-gaging stations (fig. 1; table 1).

\section{Collection}

From April 1985 to September 1988, benthic-invertebrate samples were collected four times a year at five sites within the basin, except for 1988, when no samples were collected during the fall. Samples were collected in April prior to the majority of snowmelt runoff (spring), after snowmelt runoff in late June to early July (early summer), after periods of rainfall runoff in mid August to early September (late summer), and in late October to early November (fal1) (fig. 2).

Benthic-invertebrate samples were collected by using a $1-\mathrm{ft}^{2}$ Surber sampler that has a 210- $\mu \mathrm{m}$ (micrometer) mesh net, and by using methods described by Britton and Greeson (1989). Three replicate samples were collected in riffle areas at each site. Where no riffles occurred, replicate samples were collected from bed material in a flowing part of the stream that was representative of the site. According to Canton and Chadwick (1988), three replicate samples can provide an acceptable estimate of total density of benthic invertebrates. Benthic-invertebrate samples were analyzed for total number of organisms and total number of taxa by a commercial laboratory. Onsite measurements of water temperature, specific conductance, $\mathrm{pH}$, and dissolved oxygen were made during each sample collection. As noted earlier, bed-material samples were collected in conjunction with most of the benthicinvertebrate samples (table 16 in the "Supplemental Information" section at the back of this report). Summary data for water temperature, specific conductance, $\mathrm{pH}$, and dissolved oxygen measured in Fountain Creek, in conjunction with benthic-invertebrate samples, are listed in table 10 .

\section{Fountain Creek}

Fountain Creek near Colorado Springs (site F4) was the upstream sampling site on Fountain Creek (fig. 1). Elevation at the stream gage is $6,110 \mathrm{ft}$. Benthic-invertebrate samples were collected about 50 to $100 \mathrm{ft}$ upstream from the stream gage. The stream channel at site $F 4$ is about $15-$ to $30-\mathrm{ft}$ wide and was completely shaded by mature cottonwood and willow trees. Bed material was sand, gravel, and small cobbles and had a median $d_{50}$ of $51.0 \mathrm{~mm}$ (table 8). 
Table 10.--Summary of water-quality properties and constituents measured at sites on Fountain and Monument Creeks, water years 1985-88

\begin{tabular}{|c|c|c|c|c|c|c|c|c|}
\hline \multirow{3}{*}{$\begin{array}{l}\text { Site } \\
\text { number } \\
\text { in } \\
\text { figure } \\
1\end{array}$} & \multicolumn{2}{|c|}{$\begin{array}{c}\text { Water } \\
\text { temperature } \\
\text { (degrees } \\
\text { Celsius) }\end{array}$} & \multicolumn{2}{|c|}{$\begin{array}{l}\text { Specific } \\
\text { conductance } \\
\text { (microsiemens } \\
\text { per centimeter } \\
\text { at } 25 \text { degrees } \\
\text { Celsius) }\end{array}$} & \multicolumn{2}{|c|}{$\begin{array}{c}\mathrm{pH} \\
\text { (standard } \\
\text { units) }\end{array}$} & \multicolumn{2}{|c|}{$\begin{array}{l}\text { Dissolved } \\
\text { oxygen } \\
\text { (milligrams } \\
\text { per liter) }\end{array}$} \\
\hline & \multirow{2}{*}{ Median } & \multirow{2}{*}{ Range } & & & Median & Range & Median & Range \\
\hline & & & Median & Range & & & & \\
\hline F4 & 13.0 & $7.0-17.5$ & 289 & $179-415$ & 8.3 & $7.9-8.7$ & 8.4 & $7.0-11.4$ \\
\hline F8 & 18.0 & $7.5-27.0$ & 495 & $290-953$ & 8.3 & $7.8-8.6$ & 7.5 & $6.5-11.8$ \\
\hline F13 & 17.0 & $11.0-27.0$ & 770 & $500-975$ & 7.9 & $7.4-8.1$ & 6.2 & $3.8-8.9$ \\
\hline M5 & 11.5 & $4.0-24.0$ & 210 & $122-365$ & 8.4 & $7.5-9.4$ & 8.3 & $6.0-11.6$ \\
\hline M10 & 16.5 & $10.0-26.0$ & 345 & $220-497$ & 8.3 & $7.2-8.5$ & 7.4 & $5.2-9.8$ \\
\hline
\end{tabular}

The sampling site at Fountain Creek at Colorado Springs (site F8) is located about 1.3 stream miles downstream from the confluence of Monument Creek (fig. 1). Streamflow and suspended-sediment transport at this site are affected greatly by inflows from Monument Creek (von Guerard, 1989). Benthicinvertebrate samples were collected 100 to $200 \mathrm{ft}$ upstream from the stream gage, and upstream from the confluence of Cheyenne Creek, which flows into Fountain Creek immediately upstream from the stream gage. Stream-channel width ranges from about 60 to $100 \mathrm{ft}$. Riparian vegetation included mature willows and cottonwoods. However, the stream channel generally was not shaded by the vegetation. Streambanks, which are undercut in some areas, provide localized shade. Bed material was mostly sand, gravel, and small cobbles, and the median $\mathrm{d}_{50}$ was $40.0 \mathrm{~mm}$ (table 8 ). During periods of base streamflow, the stream channel was mostly sand and gravel. The interstices between cobbles and boulders in the stream channel usually are filled with sand and gravel.

The sampling site at Fountain Creek at Security (site F13) is located at the outflow of the basin (fig. 1). Benthic invertebrates were collected about 50 to $150 \mathrm{ft}$ downstream from the stream gage. Stream-channel width was about 80 to $100 \mathrm{ft}$. The stream channel was intermittently shaded by high streambanks and mature cottonwood and willow trees. Bed material was mostly sand and gravel and had a median $d_{50}$ of $12.0 \mathrm{~mm}$ (table 8). At times, the stream channel was eroded to shale bedrock.

\section{Monument Creek}

Monument Creek at USAFA (site M5) was the upstream sampling site on Monument Creek (fig. 1). Benthic invertebrates were collected in a riffle about $300 \mathrm{ft}$ upstream from the stream gage. The stream channel in the vicinity of the gage was about $15-$ to $25-\mathrm{ft}$ wide. Intermittent shade was provided by streambanks and riparian vegetation. Bed material was sand, gravel, and small to large cobbles that had a median $d_{50}$ of $60.0 \mathrm{~mm}$ (table 8 ). 
The furthermost downstream benthic-invertebrate sampling site on Monument Creek was Monument Creek at Pikeview (site M10) (fig. 1). Benthicinvertebrate samples were collected 50 to $100 \mathrm{ft}$ downstream from the stream gage. The stream channel in the vicinity of the gage was bout 60 to 90 feet wide. Intermittent shade was provided by riparian vegetation. Bed material was sand and gravel that had a median $d_{50}$ of $1.83 \mathrm{~mm}$ (table 8 ).

\section{Benthic-Invertebrate Composition and Occurrence}

Understanding the composition and occurrence of benthic-invertebrate communities is useful for identifying stream reaches that have healthy (large numbers of organisms and taxa) or unhealthy (small numbers of organisms and taxa) aquatic environments. The presence or absence of benthic-invertebrate taxa may determine the abundance of and occurrence of fish populations. Plecoptera (stoneflies), Diptera (true flies), and Trichoptera (caddisflies) larvae are an important part of the diet of certain fish, especially trout (Pennak, 1978). There were 138 taxa identified at the 5 sampling sites on Fountain and Monument Creeks; however, only 24 were common to all sites. For the purposes of this analysis, except for pupa, taxa include all organisms identified. Benthic-invertebrate data from five selected sites on Fountain and Monument Creeks are summarized in table 19 in the "Supplemental Information" section at the back of this report.

\section{Fountain Creek}

There were 81 taxa identified at Fountain Creek near Colorado Springs (site F4). Mean densities of total organisms collected ranged from 90 to 8,800 organisms $/ \mathrm{m}^{2}$ (table 11 ), and the median was $1,400 / \mathrm{m}^{2}$. On all sampling dates, Ephemeroptera (mayflies), Diptera (true flies), and 0ligochaeta (worms) comprised about 80 to about 100 percent of the mean density of organisms.

There were major changes in community structure at site F4 during the four sampling periods. Diptera (including Cricotopus sp., Diamesa sp., Orthocladius sp., and Parametriocnemus sp.), were the most abundant organisms collected during spring at site F4 (fig. 10; table 11; and table 19 in the "Supplemental Information" section at the back of this report). Cricotopus sp. and Diamesa sp. composed from 0 to about 34 percent and about 6 to about 20 percent of the mean total density of organisms collected during spring. oligochaeta were the second most abundant groups of organisms collected at site F4 (fig. 10). Limnodrilus sp. composed 0 to about 50 percent of the mean total density of organisms collected during spring. Ephemeroptera and Trichoptera represented most of the remaining organisms collected during spring (fig. 10).

The most abundant groups of organisms collected during early summer were from the groups Oligochaeta and Ephemeroptera (fig. 11; table 11). Limnodrilus sp. was the worm most frequently collected and was the most abundant organism, comprising from 0 to about 73 percent of the mean total density of organisms collected during early summer sampling. Baetis tricaudatus was the most frequently collected and most abundant mayfly, comprising from about 9.0 to about 33 percent of the mean total density of organisms collected during early summer. Organisms from the groups Diptera and Trichoptera represented most of the remaining organisms collected during early summer (fig. 11). 
Table 11.--Sumary of mean densities of organisms for major taxonomic groups and all taxa for benthic invertebrates collected at selected sites on Fountain and Monument Creeks, water years 1985-88

[Densities are rounded to standard significant figures (Britton and Greeson, 1989); mean density of organisms including all taxa is sometimes less than the sum of mean densities of organisms of major taxa because of rounding to standard significant figures]

\begin{tabular}{|c|c|c|c|c|c|c|}
\hline \multirow{2}{*}{ Date } & \multicolumn{5}{|c|}{$\begin{array}{l}\text { Major taxa } \\
\text { (mean density of organisms per square meter) }\end{array}$} & \multirow{2}{*}{$\begin{array}{l}\text { Mean density of } \\
\text { organisms } \\
\text { including all taxa } \\
\text { (per square meter) }\end{array}$} \\
\hline & $\begin{array}{l}\text { Ephemeroptera } \\
\text { (mayflies) }\end{array}$ & $\begin{array}{l}\text { Plecoptera } \\
\text { (stoneflies) }\end{array}$ & $\begin{array}{l}\text { Trichoptera } \\
\text { (caddisflies) }\end{array}$ & $\begin{array}{l}\text { Diptera } \\
\text { (true flies) }\end{array}$ & $\begin{array}{l}\text { Oligochaeta } \\
\text { (worms) }\end{array}$ & \\
\hline & \multicolumn{6}{|c|}{ 07103700 FOUNTAIN CREEK NEAR COLORADO SPRINGS (SITE F4) } \\
\hline $\begin{array}{l}04-16-85 \\
07-11-85 \\
08-12-85 \\
10-28-85 \\
04-14-86\end{array}$ & $\begin{array}{r}39 \\
930 \\
520 \\
1,900 \\
1,200\end{array}$ & $\begin{array}{r}7 \\
110 \\
22 \\
33 \\
23\end{array}$ & $\begin{array}{r}0 \\
11 \\
7 \\
450 \\
630\end{array}$ & $\begin{array}{r}590 \\
1,300 \\
170 \\
170 \\
5,400\end{array}$ & $\begin{array}{r}600 \\
6,400 \\
100 \\
110 \\
850\end{array}$ & $\begin{array}{r}1,200 \\
8,800 \\
840 \\
2,600 \\
8,200\end{array}$ \\
\hline $\begin{array}{l}07-10-86 \\
08-25-86 \\
11-05-86 \\
04-27-87 \\
07-15-87\end{array}$ & $\begin{array}{r}1,100 \\
180 \\
800 \\
320 \\
470\end{array}$ & $\begin{array}{r}21 \\
0 \\
11 \\
8 \\
11\end{array}$ & $\begin{array}{r}120 \\
0 \\
120 \\
0 \\
0\end{array}$ & $\begin{array}{r}400 \\
90 \\
320 \\
900 \\
320\end{array}$ & $\begin{array}{r}1,800 \\
40 \\
100 \\
140 \\
460\end{array}$ & $\begin{array}{r}3,500 \\
310 \\
1,400 \\
1,400 \\
1,300\end{array}$ \\
\hline $\begin{array}{l}08-26-87 \\
11-04-87 \\
04-25-88 \\
06-30-88 \\
09-07-88\end{array}$ & $\begin{array}{r}1,100 \\
1,200 \\
47 \\
160 \\
7\end{array}$ & $\begin{array}{r}68 \\
47 \\
11 \\
4 \\
0\end{array}$ & $\begin{array}{r}65 \\
190 \\
7 \\
32 \\
18\end{array}$ & $\begin{array}{r}290 \\
160 \\
450 \\
120 \\
58\end{array}$ & $\begin{array}{r}36 \\
150 \\
74 \\
120 \\
7\end{array}$ & $\begin{array}{r}1,600 \\
1,700 \\
630 \\
490 \\
90\end{array}$ \\
\hline
\end{tabular}

07105500 FOUNTAIN CREEK AT COLORADO SPRINGS (SITE F8)

\begin{tabular}{|c|c|c|c|c|c|c|}
\hline $\begin{array}{l}04-16-85 \\
07-11-85 \\
08-12-85 \\
10-28-85 \\
04-14-86\end{array}$ & $\begin{array}{r}18 \\
440 \\
0 \\
15 \\
7\end{array}$ & $\begin{array}{r}26 \\
11 \\
0 \\
0 \\
0\end{array}$ & $\begin{array}{r}0 \\
18 \\
4 \\
7 \\
0\end{array}$ & $\begin{array}{r}330 \\
3,500 \\
48 \\
180 \\
220\end{array}$ & $\begin{array}{r}97 \\
480 \\
47 \\
220 \\
110\end{array}$ & $\begin{array}{r}470 \\
4,400 \\
120 \\
430 \\
340\end{array}$ \\
\hline $\begin{array}{l}07-10-86 \\
08-25-86 \\
11-05-86 \\
04-27-87 \\
07-15-87\end{array}$ & $\begin{array}{l}54 \\
36 \\
11 \\
54 \\
93\end{array}$ & $\begin{array}{l}0 \\
4 \\
0 \\
4 \\
4\end{array}$ & $\begin{array}{l}4 \\
4 \\
0 \\
0 \\
7\end{array}$ & $\begin{array}{l}270 \\
160 \\
420 \\
730 \\
530\end{array}$ & $\begin{array}{r}39 \\
51 \\
640 \\
950 \\
120\end{array}$ & $\begin{array}{r}380 \\
260 \\
1,100 \\
1,700 \\
760\end{array}$ \\
\hline $\begin{array}{l}09-01-87 \\
11-04-87 \\
04-25-88 \\
06-30-88 \\
09-07-88\end{array}$ & $\begin{array}{r}47 \\
120 \\
0 \\
11 \\
68\end{array}$ & $\begin{array}{l}4 \\
0 \\
0 \\
7 \\
0\end{array}$ & $\begin{array}{l}0 \\
0 \\
0 \\
4 \\
0\end{array}$ & $\begin{array}{r}230 \\
570 \\
95 \\
36 \\
590\end{array}$ & $\begin{array}{l}50 \\
90 \\
43 \\
51 \\
14\end{array}$ & $\begin{array}{l}330 \\
780 \\
140 \\
120 \\
680\end{array}$ \\
\hline \multicolumn{7}{|c|}{ 07105800 FOUNTAIN CREEK AT SECURITY (SITE F13) } \\
\hline $\begin{array}{l}04-16-85 \\
07-11-85 \\
08-12-85 \\
10-28-85 \\
04-14-86\end{array}$ & $\begin{array}{r}0 \\
54 \\
0 \\
4 \\
0\end{array}$ & $\begin{array}{l}4 \\
0 \\
0 \\
0 \\
0\end{array}$ & $\begin{array}{l}0 \\
0 \\
0 \\
0 \\
0\end{array}$ & $\begin{array}{r}90 \\
2,300 \\
51 \\
32 \\
470\end{array}$ & $\begin{array}{r}190 \\
9,300 \\
110 \\
1,700 \\
1,900\end{array}$ & $\begin{array}{r}280 \\
12,000 \\
160 \\
1,700 \\
2,400\end{array}$ \\
\hline $\begin{array}{l}07-10-86 \\
08-25-86 \\
11-05-86 \\
04-27-87 \\
07-15-87\end{array}$ & $\begin{array}{r}57 \\
0 \\
4 \\
11 \\
29\end{array}$ & $\begin{array}{l}0 \\
0 \\
4 \\
0 \\
0\end{array}$ & $\begin{array}{l}0 \\
0 \\
0 \\
0 \\
0\end{array}$ & $\begin{array}{r}360 \\
160 \\
81 \\
1,800 \\
360\end{array}$ & $\begin{array}{r}2,400 \\
120 \\
3,800 \\
16,000 \\
6,200\end{array}$ & $\begin{array}{r}2,800 \\
280 \\
3,900 \\
18,000 \\
6,600\end{array}$ \\
\hline $\begin{array}{l}09-01-87 \\
11-04-87 \\
04-25-88 \\
06-30-88 \\
09-07-88\end{array}$ & $\begin{array}{r}43 \\
0 \\
7 \\
15 \\
29\end{array}$ & $\begin{array}{l}0 \\
0 \\
0 \\
4 \\
0\end{array}$ & $\begin{array}{l}0 \\
0 \\
4 \\
0 \\
0\end{array}$ & $\begin{array}{r}200 \\
140 \\
560 \\
200 \\
11,000\end{array}$ & $\begin{array}{r}1,100 \\
4,100 \\
2,500 \\
76 \\
13,000\end{array}$ & $\begin{array}{r}1,300 \\
4,300 \\
3,000 \\
290 \\
24,000\end{array}$ \\
\hline
\end{tabular}


Table 11.--Summary of mean densities of organisms for major taxonomic groups and all taxa for benthic invertebrates collected at selected sites on Fountain and Monument Creeks, water years 1985-88--Continued

\begin{tabular}{|c|c|c|c|c|c|c|}
\hline \multirow{2}{*}{ Date } & \multicolumn{5}{|c|}{$\begin{array}{l}\text { Major taxa } \\
\text { (mean density of organisms per square meter) }\end{array}$} & \multirow{2}{*}{$\begin{array}{l}\text { Mean density of } \\
\text { organisms } \\
\text { including all taxa } \\
\text { (per square meter) }\end{array}$} \\
\hline & $\begin{array}{c}\text { Ephemeroptera } \\
\text { (mayflies) }\end{array}$ & $\begin{array}{l}\text { Plecoptera } \\
\text { (stoneflies) }\end{array}$ & $\begin{array}{l}\text { Trichoptera } \\
\text { (caddisflies) }\end{array}$ & $\begin{array}{c}\text { Diptera } \\
\text { (true flies) }\end{array}$ & $\begin{array}{l}\text { Oligochaeta } \\
\text { (worms) }\end{array}$ & \\
\hline
\end{tabular}

07103780 MONUMENT CREEK ABOVE NORTH GATE BOULEVARD AT U.S. AIR FORCE ACADEMY (SITE M5)

\begin{tabular}{|c|c|c|c|c|c|c|}
\hline $\begin{array}{l}04-16-85 \\
07-11-85 \\
08-12-85 \\
10-29-85 \\
04-14-86\end{array}$ & $\begin{array}{r}22 \\
8,300 \\
5,200 \\
7,000 \\
720\end{array}$ & $\begin{array}{r}4 \\
93 \\
57 \\
770 \\
25\end{array}$ & $\begin{array}{r}0 \\
320 \\
780 \\
2,900 \\
220\end{array}$ & $\begin{array}{r}180 \\
5,600 \\
3,400 \\
2,200 \\
2,000\end{array}$ & $\begin{array}{r}250 \\
3,900 \\
29 \\
5,000 \\
3,500\end{array}$ & $\begin{array}{r}460 \\
18,000 \\
9,500 \\
18,000 \\
6,400\end{array}$ \\
\hline $\begin{array}{l}07-10-86 \\
08-25-86 \\
11-05-86 \\
04-27-87 \\
07-14-87\end{array}$ & $\begin{array}{r}4,300 \\
7,200 \\
4,800 \\
350 \\
3,000\end{array}$ & $\begin{array}{r}0 \\
270 \\
170 \\
8 \\
0\end{array}$ & $\begin{array}{r}730 \\
6,300 \\
4,900 \\
100 \\
1,000\end{array}$ & $\begin{array}{l}1,700 \\
1,800 \\
6,800 \\
1,400 \\
2,000\end{array}$ & $\begin{array}{r}6,200 \\
1,600 \\
2,800 \\
6,100 \\
580\end{array}$ & $\begin{array}{r}13,000 \\
17,000 \\
20,000 \\
8,000 \\
6,600\end{array}$ \\
\hline $\begin{array}{l}08-26-87 \\
11-04-87 \\
04-25-88 \\
06-30-88 \\
09-07-88\end{array}$ & $\begin{array}{r}4,300 \\
940 \\
25 \\
3,200 \\
2,100\end{array}$ & $\begin{array}{r}110 \\
78 \\
4 \\
14 \\
44\end{array}$ & $\begin{array}{r}2,700 \\
920 \\
25 \\
590 \\
2,200\end{array}$ & $\begin{array}{r}2,300 \\
2,400 \\
290 \\
1,700 \\
830\end{array}$ & $\begin{array}{r}620 \\
6,100 \\
330 \\
310 \\
130\end{array}$ & $\begin{array}{r}10,000 \\
10,000 \\
680 \\
5,900 \\
5,300\end{array}$ \\
\hline
\end{tabular}

07104000 MONUMENT CREEK AT PIKEVIEW (SITE M10)

\begin{tabular}{|c|c|c|c|c|c|c|}
\hline $\begin{array}{l}04-16-85 \\
07-11-85 \\
08-12-85 \\
10-28-85 \\
04-14-86\end{array}$ & $\begin{array}{r}0 \\
130 \\
0 \\
0 \\
0\end{array}$ & $\begin{array}{l}0 \\
0 \\
0 \\
4 \\
7\end{array}$ & $\begin{array}{l}0 \\
0 \\
0 \\
0 \\
0\end{array}$ & $\begin{array}{r}28 \\
400 \\
30 \\
11 \\
100\end{array}$ & $\begin{array}{r}14 \\
370 \\
120 \\
230 \\
43\end{array}$ & $\begin{array}{r}42 \\
910 \\
160 \\
240 \\
150\end{array}$ \\
\hline $\begin{array}{l}07-10-86 \\
08-25-86 \\
11-05-86 \\
04-27-87 \\
07-14-87\end{array}$ & $\begin{array}{r}11 \\
14 \\
0 \\
0 \\
210\end{array}$ & $\begin{array}{l}0 \\
0 \\
0 \\
0 \\
0\end{array}$ & $\begin{array}{l}0 \\
0 \\
0 \\
0 \\
7\end{array}$ & $\begin{array}{r}340 \\
80 \\
200 \\
79 \\
260\end{array}$ & $\begin{array}{r}270 \\
110 \\
790 \\
1,100 \\
180\end{array}$ & $\begin{array}{r}640 \\
200 \\
990 \\
1,200 \\
670\end{array}$ \\
\hline $\begin{array}{l}08-26-87 \\
11-04-87 \\
04-25-88 \\
06-30-88 \\
09-07-88\end{array}$ & $\begin{array}{r}0 \\
0 \\
0 \\
18 \\
8\end{array}$ & $\begin{array}{l}0 \\
0 \\
0 \\
0 \\
0\end{array}$ & $\begin{array}{r}0 \\
0 \\
0 \\
0 \\
14\end{array}$ & $\begin{array}{r}300 \\
110 \\
80 \\
31 \\
460\end{array}$ & $\begin{array}{r}360 \\
250 \\
47 \\
290 \\
140\end{array}$ & $\begin{array}{l}660 \\
370 \\
130 \\
340 \\
640\end{array}$ \\
\hline
\end{tabular}


EXPLANATION

F4 NUMBER REFERS TO SAMPLING SITE IN TABLE 1

19.4 ALL VALUES ARE IN PERCENT OF TOTAL

ORGANISMS AND ARE BASED ON UNROUNDED NUMBERS

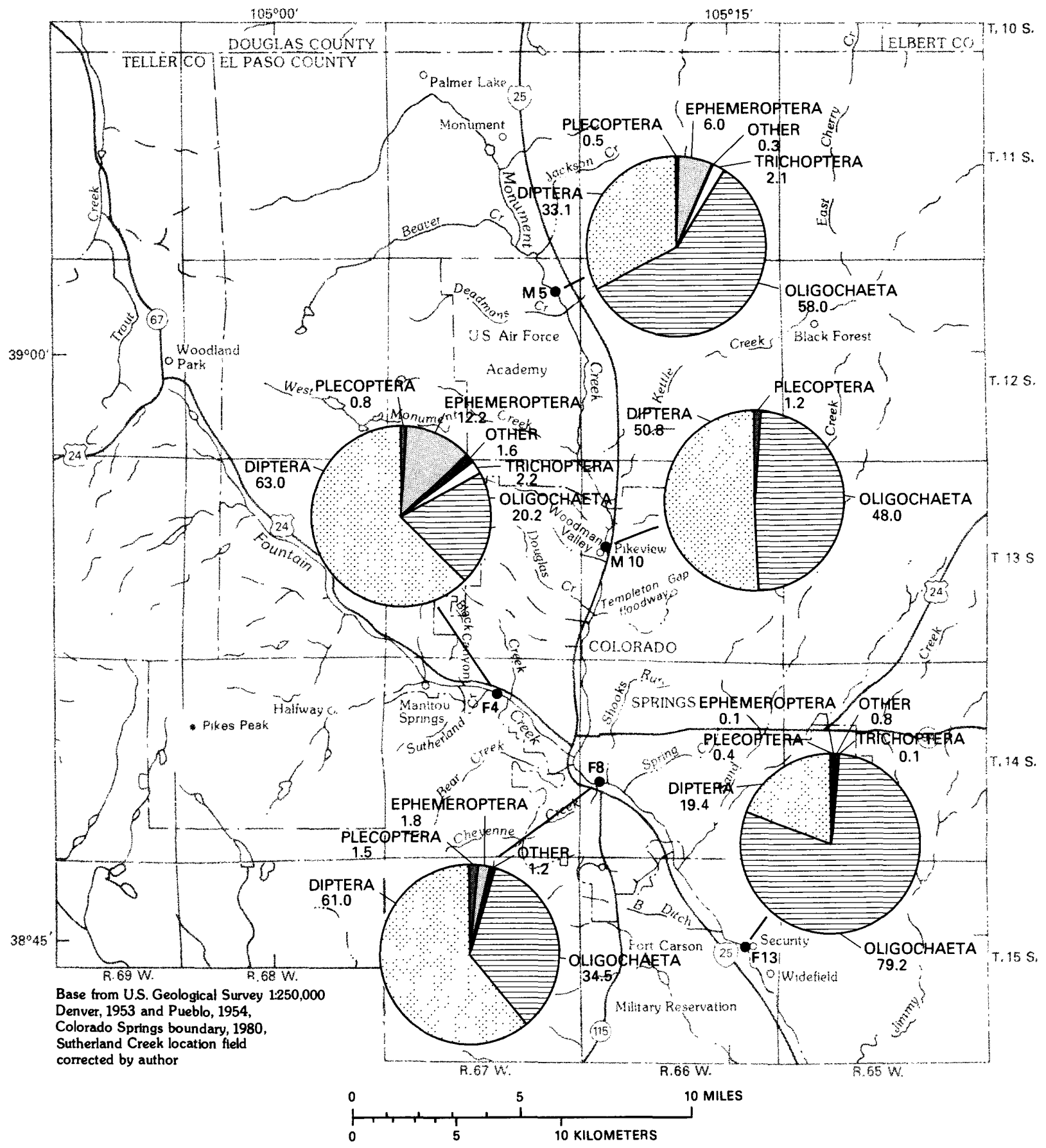

Figure 10.--Mean percentage composition of major taxonomic groups collected at selected sites on Fountain and Monument Creeks during spring (April). 


\section{EXPLANATION}

F4 NUMBER REFERS TO SAMPLING STTE IN TABLE 1

19.4 ALL VALUES ARE IN PERCENT OF TOTAL ORGANISMS AND ARE BASED ON UNROUNDED NUMBERS



Figure 11.--Mean percentage composition of major taxonomic groups collected at selected sites on Fountain and Monument Creeks during early summer (late June to early July). 
During late summer there was a decrease in the number of worms collected. Taxa from the groups Ephemeroptera and Diptera were the most abundant organisms collected during late summer (fig. 12). Baetis tricaudatus was the mayfly that occurred most frequently, comprising about 7.8 to about 61 percent of the mean total density of organisms collected. The true fly most frequently collected was Parametriocnemus sp., comprising from 0 to about 28 percent of the total organisms collected. Organisms from the groups Oligochaeta, Trichoptera, and Plecoptera represented most of the remaining organisms collected during late summer (fig. 12).

Mayflies were the most abundant organisms collected at site F4 during fall (fig. 13). Baetis tricaudatus comprised from about 34 to about 69 percent of the mean density of total organisms collected. Organisms from the groups Diptera, Trichoptera, and 0ligochaeta represented the majority of the remaining organisms (fig. 13).

There were 63 taxa identified at Fountain Creek at Colorado Springs (site F8). Mean densities of total organisms ranged from 120 to 4,400 organisms $/ \mathrm{m}^{2}$ (table 11 ), and the median was 430 organisms $/ \mathrm{m}^{2}$. Seasonal changes in community structure were not apparent at this site; taxa from the groups Diptera and 0ligochaeta were the most abundant organisms during all sampling periods. True flies were the most frequently collected organisms during all sampling periods (figs. 10-13). The true fly, Parametriocnemus sp. was collected during every sampling period and comprised about 2.7 to about 68 percent of the mean total density of organisms collected. Limnodrilus sp. was the most frequently collected worm, comprising from 0 to about 58 percent of the mean total density of organisms collected. Organisms from the groups Ephemeroptera, Plecoptera, and Trichoptera represented the majority of the remaining organisms (table 11). Caddisflies were not collected during spring but were collected during 7 of the remaining 11 sampling periods (table 11).

Fifty-five taxa were identified at Fountain Creek at Security (site F13). Mean density of total organisms ranged from 160 to 24,000 organisms $/ \mathrm{m}^{2}$ (table 11), and the median was 2,800 organisms $/ \mathrm{m}^{2}$. Worms were the most abundant and frequently collected organisms during all sampling periods (figs. 10-13). Limodrilus sp. comprised from about 0 to about 97 percent of the mean total density of organisms collected. True flies, mainly Parametriocnemus sp., were the second most abundant group of organisms collected (figs. 10-13; table 11). Mayflies were present during 10 sampling periods. Stoneflies were only collected three times, once during spring, once during early summer, and once during fall. Caddisflies were present during only one sampling period (table 11).

\section{Monument Creek}

There were 78 taxa identified at Monument Creek at USAFA (site M5). Taxa from the groups Ephemeroptera, Diptera, Trichoptera, and Oligochaeta accounted for greater than 95 percent of total organisms sampled during all sampling periods. Plecoptera, although not present in large numbers, were collected during all but two sampling periods. Mean density of total organisms ranged from 460 to 20,000 organisms $/ \mathrm{m}^{2}$ (table 11), and the median was 9,500 organisms $/ \mathrm{m}^{2}$. 
EXPLANATION

F4 NUMBER REFERS TO SAMPLING SITE IN TABLE 1

19.4 ALL VALUES ARE IN PERCENT OF TOTAL ORGANISMS AND ARE BASED ON UNROUNDED NUMBERS

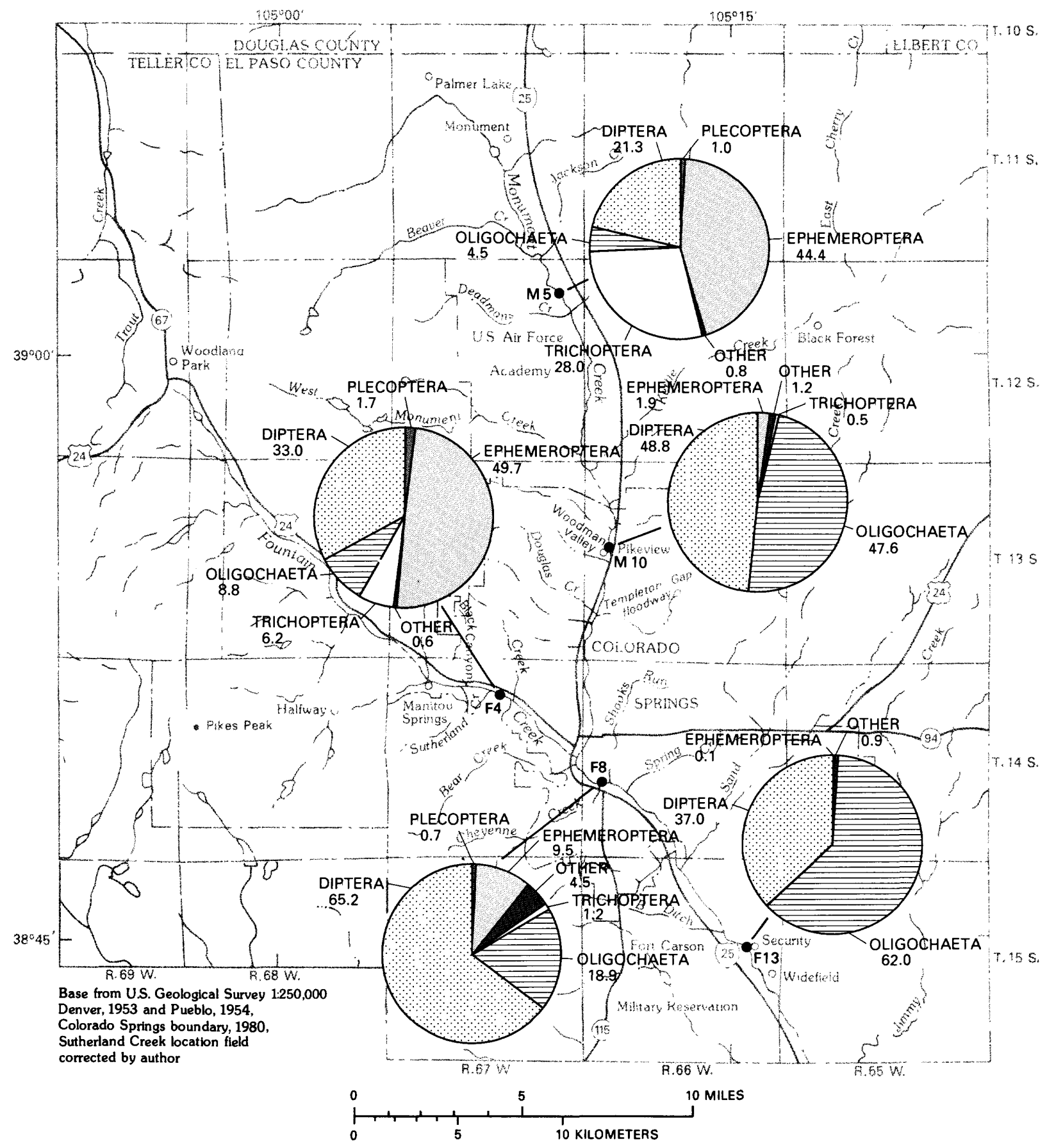

Figure 12.--Mean percentage composition of major taxonomic groups collected at selected sites on Fountain and Monument Creeks during late summer (mid-August to early September). 


\section{EXPLANATION}

F4 NUMBER REFERS TO SAMPLING SITE IN TABLE 1

19.4 ALL VALUES ARE IN PERCENT OF TOTAL ORGANISMS AND ARE BASED ON UNROUNDED NUMBERS

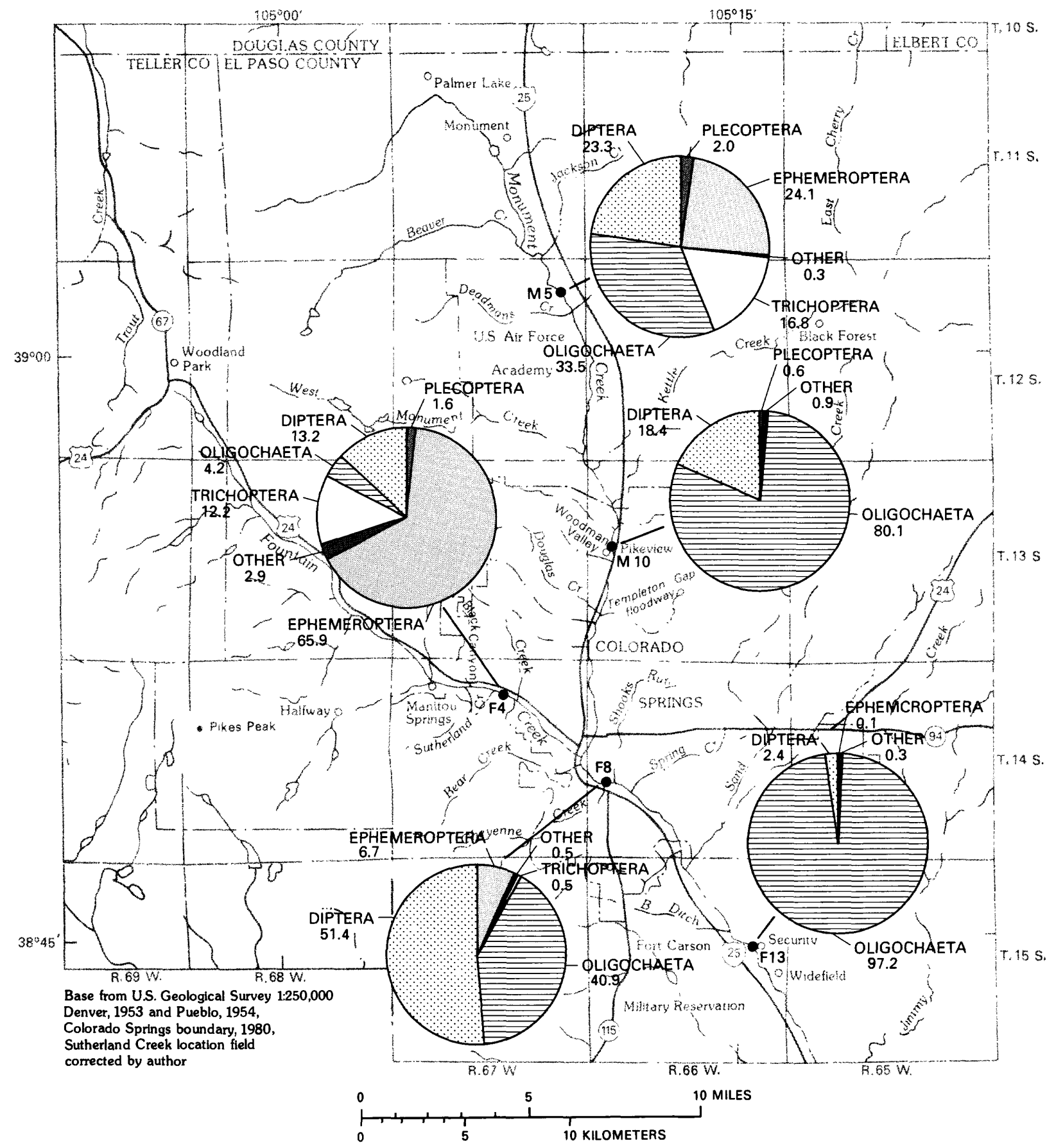

Figure 13.--Mean percentage composition of major taxonomic groups collected at selected sites on Fountain and Monument Creeks during fall (late October to early November). 
There were large changes in community structure at site M5 during the four sampling periods. During spring sampling, Oligochaeta and Diptera comprised the majority of the total organisms collected (fig. 10). Of the worms collected, Limnodrilus sp. and Tubificidae accounted for about 49 to about 76 percent of the mean total density of organisms collected during spring. Cricotopus sp., Diamesa sp, Orthocladius sp., and Parametriocnemus sp. were the most abundant true flies collected during the spring sampling.

During early summer, Ephemeroptera replaced Oligochaeta as the most abundant group of organisms collected at site M5 (fig. 11). Baetis bicaudatus and Baetis tricaudatus were the most abundant mayflies collected, comprising about 29 to about 45 percent of the mean total density of organisms collected. Diptera were the second most abundant group of organisms collected.

Parametriocnemus $\mathrm{sp}$. and Simulium sp. were the most abundant among the Diptera group, comprising from 8.5 to about 22 percent of the mean total density of organisms collected.

Ephemeroptera and Trichoptera were the most abundant group of organisms collected during late summer (fig. 12). Baetis bicaudatus and Baetis tricaudatus were the most abundant mayflies collected, comprising about 30 to about 54 percent of the mean total density of organisms. Hydropsyche sp. was the most abundant caddisfly collected, comprising about 8.2 to about 38 percent of the mean total density of organisms. In addition, the abundance of the caddisfly, Hydropsyche sp., and the truefly, Simulium sp., is notable because they are characterized as clingers and require a stable habitat (such as cobbles) (Merritt and Cummins, 1984).

There was a change in dominant taxa from Ephemeroptera to Oligochaeta during the fall at site M5 (fig. 13). The worms, Limnodrilus sp., and immature Tubificidae, composed about 14 to about 61 percent of the mean total density of organisms collected. Ephemeroptera, Diptera, and Trichoptera composed about 43 to about 82 percent of the mean total density of organisms during fall (table 11).

There were 41 taxa identified at Monument Creek at Pikeview (site M10). Mean density of total organisms ranged from 42 to 1,200 organisms $/ \mathrm{m}^{2}$, and the median was 370 organisms $/ \mathrm{m}^{2}$ (table 11). 0ligochaeta and Diptera were the most frequently collected and the most abundant groups of organisms collected during all sampling periods (figs. 10-13). Limnodrilus sp. was the most frequently occurring 0ligochaeta, comprising from 0 to about 92 percent of the mean total density of organisms collected during all sampling periods. Cricotopus sp., Diamesa sp., Micropsectra sp., Orthoclaudius sp., Parametriocnemus sp., and Phaenopsectra sp. were the most abundant true flies collected during all sampling periods. Mayflies were collected during only six sampling periods, and stoneflies and caddisflies were collected during only two sampling periods (table 11). 


\section{Comparison of Sampling Results Between Sites}

The following is a discussion of differences in species composition between sites as defined by the similarity index and by the percent similarity. Also discussed are the results of analysis of variance and multiple comparison tests on the ranks of mean densities of organisms for all taxa and mean densities of organisms for the major taxa occurring at all five sampling sites.

\section{Similarity Indices}

Evaluation of the similarity index and percent similarity can be useful in determining which sites are the most similar taxonomically. The similarity index provides a comparison of taxa between two sites. However, the index does not take into account the relative abundance of taxa. The similarity index is calculated by using the following formula (Odum, 1971):

$$
S=\frac{2 c}{a+b}
$$

where $\mathrm{S}=$ similarity index;

$c=$ number of taxa common to both samples or sites;

$a=$ number of taxa in sample at site a; and

$b=$ number of taxa in sample at site $b$.

The similarity index values range from 0 to 1 ; the closer the value to 1 , the greater the similarity in taxonomic composition between samples or sites.

Percent similarity is a measure of the abundance of taxa common to two samples or sites. Percent similarity is calculated by summing the smallest percentage of total organisms for each taxa common to both samples or sites. Percent similarity ranges from 0 to 100 percent; the closer the value is to 100 percent, the greater the relative importance of similar taxa between samples or sites (Whittaker, 1975).

Evaluation of the similarity index and percent similarity together can be useful in understanding the vagaries of comparing taxonomic data between sites. For example, for the samples collected during November 1987 at Fountain Creek at Security (site F13) and Monument Creek at USAFA (site M5), the similarity index and percent similarity calculated were about 0.26 and about 63. The small similarity index indicates little similarity in taxonomic composition between sites F13 and M5. Only 5 taxa were collected at site F13, whereas 33 were collected at site M5 during November 1987 (table 19 in the "Supplemental Information" section at the back of this report). However, the percent similarity of about 63 indicates that the sites may be similar in terms of the relative abundance of taxa common to both sites. Further analysis indicates that 0ligochaetes composed about 95 percent of the mean total density of organisms at site F13 and about 61 percent at site M5 during November 1987 (table 11). Thus, while during November 1987 there was 1ittle similarity between sites based on number of similar taxa, the density of similar taxa, 0ligochaetes, results in greater percentage similarity between sites. In this instance, percent similarity helped to identify the large effect that 01 igochaetes have on benthic-invertebrate densities at sites F13 and M5 for a specific sampling period. 
Values for similarity indexes and percent similarities between all sites are summarized in table 12. The largest median values for similarity index calculated were between Fountain Creek at Colorado Springs (site F8) and Monument Creek at Pikeview (site M10), and between Fountain Creek near Colorado Springs (site F4) and Monument Creek at USAFA (site M5) (table 12).

Table 12.--Summary of values of similarity index and percent similarity for benthic-invertebrate sampling sites on Fountain and Monument Creeks, water years 1985-88

[Values for similarity index and percent similarity are calculated from unrounded numbers]

\begin{tabular}{|c|c|c|c|c|c|c|}
\hline \multirow{2}{*}{$\begin{array}{c}\text { Site } \\
\text { number } \\
\text { in } \\
\text { figure } 1\end{array}$} & \multicolumn{3}{|c|}{$\begin{array}{l}\text { Similarity } \\
\text { index }\end{array}$} & \multicolumn{3}{|c|}{$\begin{array}{l}\text { Percent } \\
\text { similarity }\end{array}$} \\
\hline & Maximum & Minimum & Median & Maximum & Minimum & Median \\
\hline $\mathrm{F} 4-\mathrm{F} 8$ & 0.69 & 0.38 & 0.48 & 50.8 & 11.9 & 40.2 \\
\hline $\mathrm{F} 4-\mathrm{F} 13$ & .64 & .22 & .40 & 83.4 & 5.1 & 28.0 \\
\hline F4-M5 & .64 & .33 & .54 & 73.9 & 25.5 & 44.3 \\
\hline F4-M10 & .54 & .17 & .32 & 59.7 & 2.8 & 36.4 \\
\hline $\mathrm{F} 8-\mathrm{F} 13$ & .74 & .30 & .50 & 64.5 & 13.4 & 46.3 \\
\hline F8-M5 & .78 & .33 & .50 & 72.1 & 15.6 & 37.9 \\
\hline F8-M10 & .64 & .36 & .55 & 73.5 & 8.0 & 57.8 \\
\hline F13-M5 & .62 & .20 & .41 & 69.8 & 9.4 & 29.4 \\
\hline F13-M10 & .72 & .12 & .45 & 95.0 & 31.8 & 58.0 \\
\hline M5-M10 & .67 & .15 & .41 & 80.7 & 8.4 & 40.5 \\
\hline
\end{tabular}

Comparison of Densities of Organisms Between Sites

Average mean densities of organisms for all taxa and average mean densities of organisms of the major taxa, Ephemeroptera, Plecoptera, Trichoptera, Diptera, and 0ligochaeta for the five benthic-intertebrate sampling sites (fig. 1; table 1) were compared using analysis of variance (ANOVA). For the purpose of this analysis, the data were ranked, and ANOVA was done on the ranks of the data (Conover and Iman, 1981). The group means of ranked data for total densities of organisms and densities of organisms of the major taxa groups between the five sites were significantly different $(p<0.05)$. Because there is a difference in average mean densities of organisms between sites, it would be useful to determine which sites were different and which sites were similar. The difference in average mean densities of organisms between sites was determined using Tukeys studentized range test (Statistical Analysis System Institute, 1985). The Tukeys studentized range test is a multiple comparison test that sets the overall error rate to a stated alpha level, in this instance alpha $=0.05$. The overall error rate is the overall probability of declaring at least one false difference between sites. 
Box plots were used to compare mean densities of organisms for all taxa and mean densities of organisms for major taxa at the five sites. A box plot is a useful tool for visually examining the central tendency and dispersion of a group of data, and is useful for comparing two or more groups of data. An example of a box plot is shown in figure 14. To construct a box plot, the median value is plotted as a horizontal line. The 25 th and 75 th percentiles are used as the upper and lower ends of the box. The box represents the interquartile range. Vertical lines extend to within 1.5 times the interquartile range. Outliers within 1.5 to 3.0 times the interquartile range are shown as "*" and far out values greater or less than 3.0 times the interquartile range are shown as "•" (Martin and Crawford, 1987). Mean densities of organisms for all taxa and mean densities of organisms for major taxa collected at the five sites are summarized in box plots (figs. 15A-F).

The Tukeys test was applied to ranks of the data used in the ANOVA procedure. Results of multiple comparison tests between the five benthicinvertebrate sampling sites are included in figures $15 A-F$. Sampling sites where average mean densities are similar $(p>0.05)$ have been assigned the same number. For example, average mean densities of organisms for all taxa between sites $F 13$ and M5 are considered similar and are designated by the number 1 (fig. 15A). However, average mean densities of organisms for all taxa at site F13 also are similar to site F4, and this is designated by the number 2 (fig. 15A). In this instance, average mean densities of organisms for all taxa were similar between sites F13 and M5, sites F13 and F4, but not sites F4 and M5.

Average mean densities of organisms for all taxa for Fountain Creek near Colorado Springs (site F4) and Fountain Creek at Colorado Springs (site F8) were similar $(p>0.05)$ ( $f i g .15 A)$. The similarity of average mean densities of organisms for all taxa between sites F4 and F8 are a result of the occurrence of bottom sprawling Diptera (Parametriocnemus sp.) and organisms from the group 0ligochaeta (figs. 15E, $F$ ). However, benthic-invertebrate habitat is less favorable at site F8 than at site F4. The effects of increased streamflow and sediment discharge from Monument Creek on stream habitat are evident at site F8; the more habitat-sensitive taxa, Ephemeroptera, Plecoptera, and Trichoptera are less abundant than at site $F 4$ (figs. 15B,C,D).

Fountain Creek at Security (site F13) and Monument Creek at USAFA (site M5) had the largest densities of total organisms collected. The average mean densities of organisms for all taxa at sites F13 and M5 were similar ( $>0.05)$ (fig. 15A). Sites $F 13$ and M5 represent the extremes in instream-habitat conditions in the study area with respect to stability of streambed and variability of streamflow. Site F13 has a mobile streambed. Streamflow at site F13 is affected by urbanization in the basin and is especially variable during rainfall runoff. Site $M 5$ has a stable streambed, drains a mostly rural part of the basin, and has a smaller range of streamflows (table 2). The similarity of average mean densities of total organisms is a result of the large densities of Oligochaetes collected at sites F13 and M5 (fig. 15F; table 11). Oligochaetes are able to exist in a wide range of habitats as opposed to the more habitat-sensitive taxa of Ephemeroptera, Plecoptera, and Trichoptera (Pennak, 1978). Oligochaeta is the only major taxa group for which average mean densities of organisms were similar between sites F13 and M5 (figs. 15A-F). The more habitat-sensitive taxa, Ephemeroptera, Plecoptera, and Trichoptera were substantially more abundant at site M5 than at site F13 (figs. $15 B, C, D$ ). 


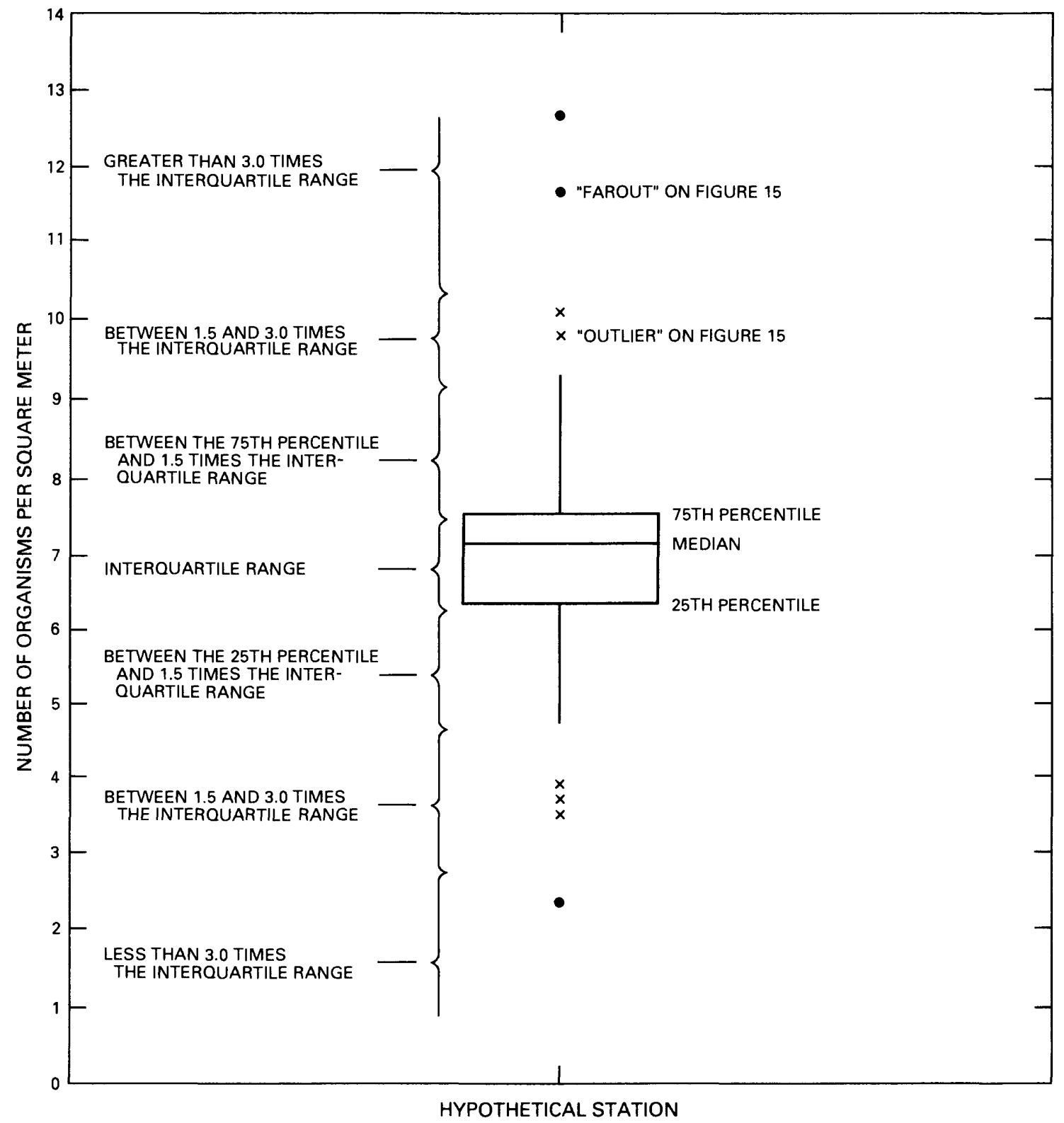

Figure 14.--Example of a box plot. 


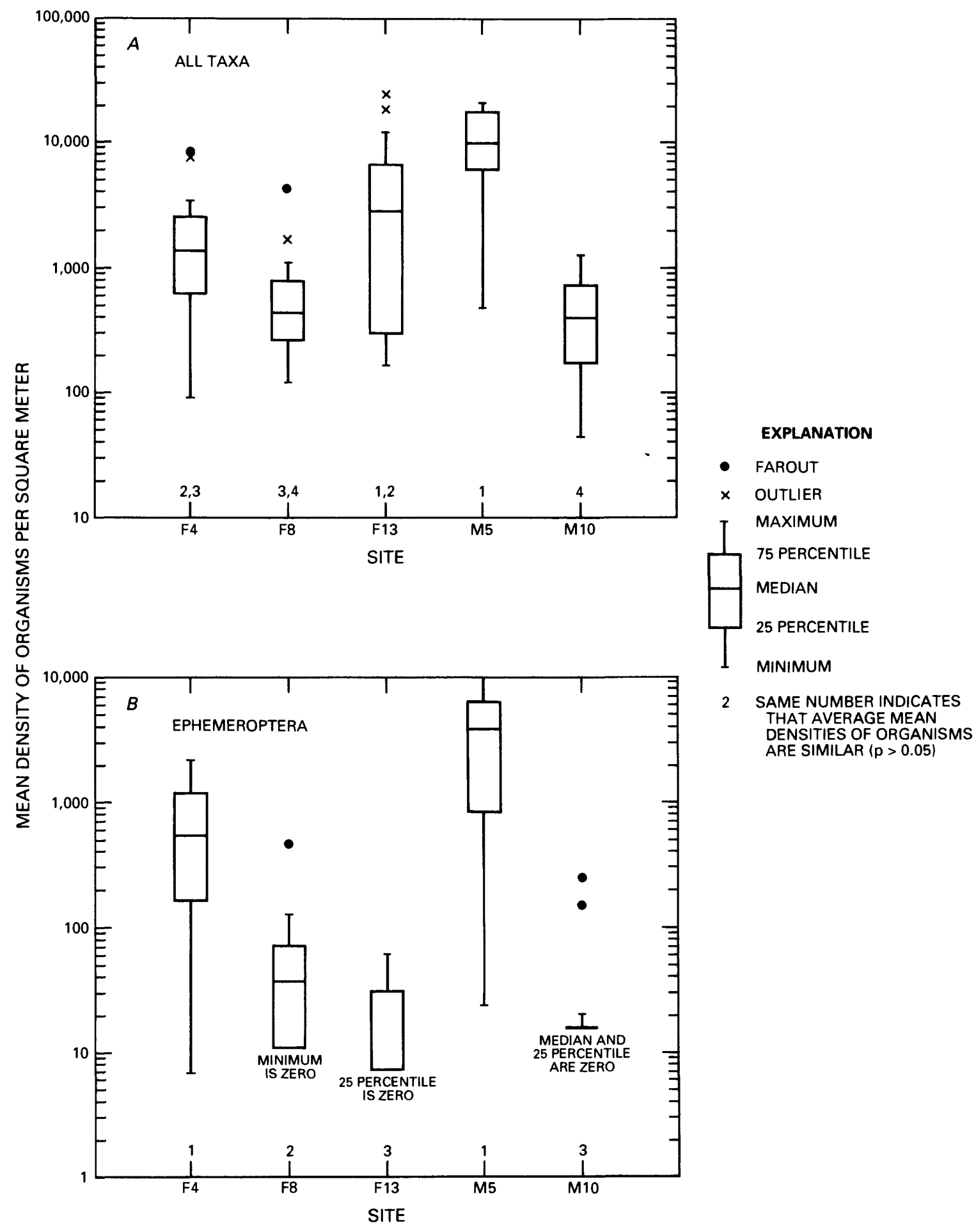

Figure 15.--Box plot of mean densities of organisms for all taxa and major taxonomic groups for benthic invertebrates collected on Fountain and Monument Creeks. 


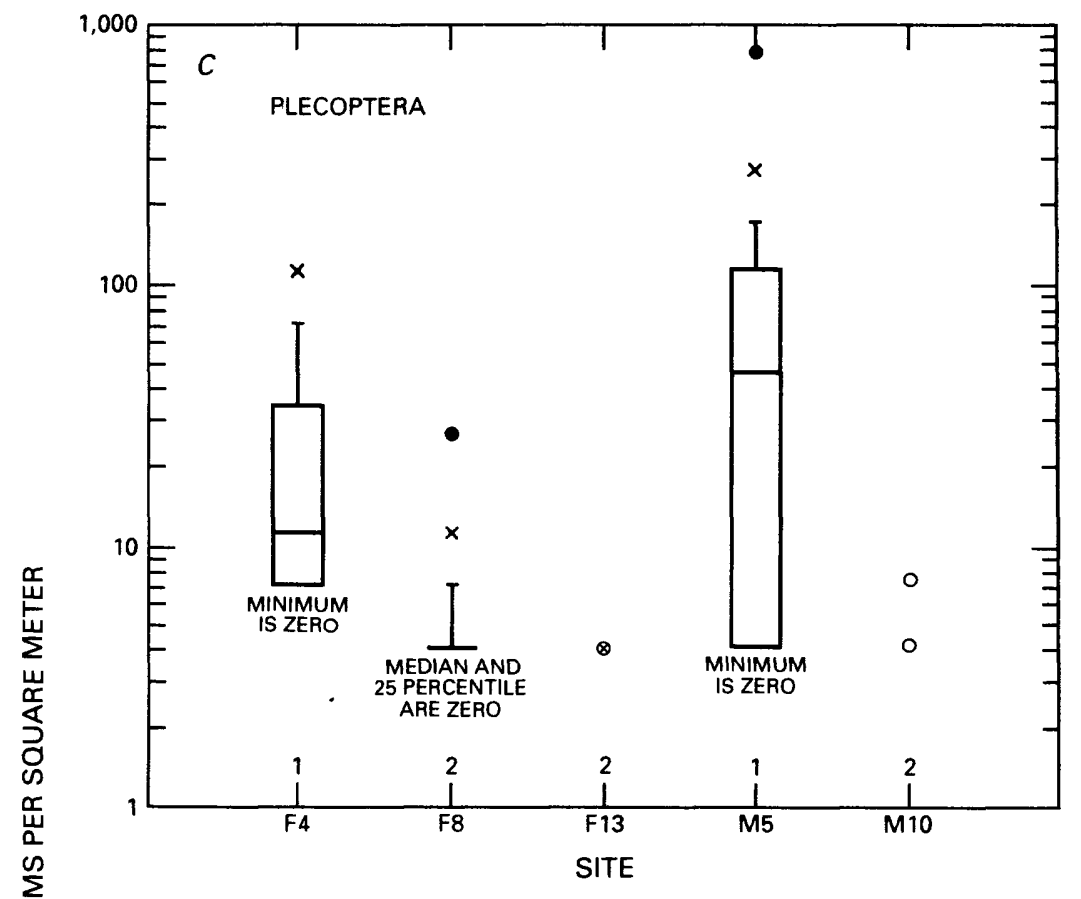

EXPLANATION

- farout

$\times$ OUTLIER

T MAXIMUM

75 PERCENTILE

MEDIAN

25 PERCENTILE

号

茨

10,

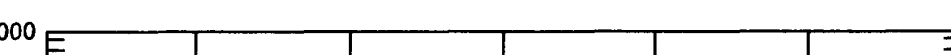

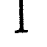

MINIMUM

- SINGLE DATA POINT

- MUltiple data poINTS

3 SAME NUMBER INDICATES THAT AVERAGE MEAN DENSITIES OF ORGANISMS ARE SIMILAR' $(p>0.05)$

Figure 15.--Box plot of mean densities of organisms for all taxa and major taxonomic groups for benthic invertebrates collected on Fountain and Monument Creeks--Continued. 


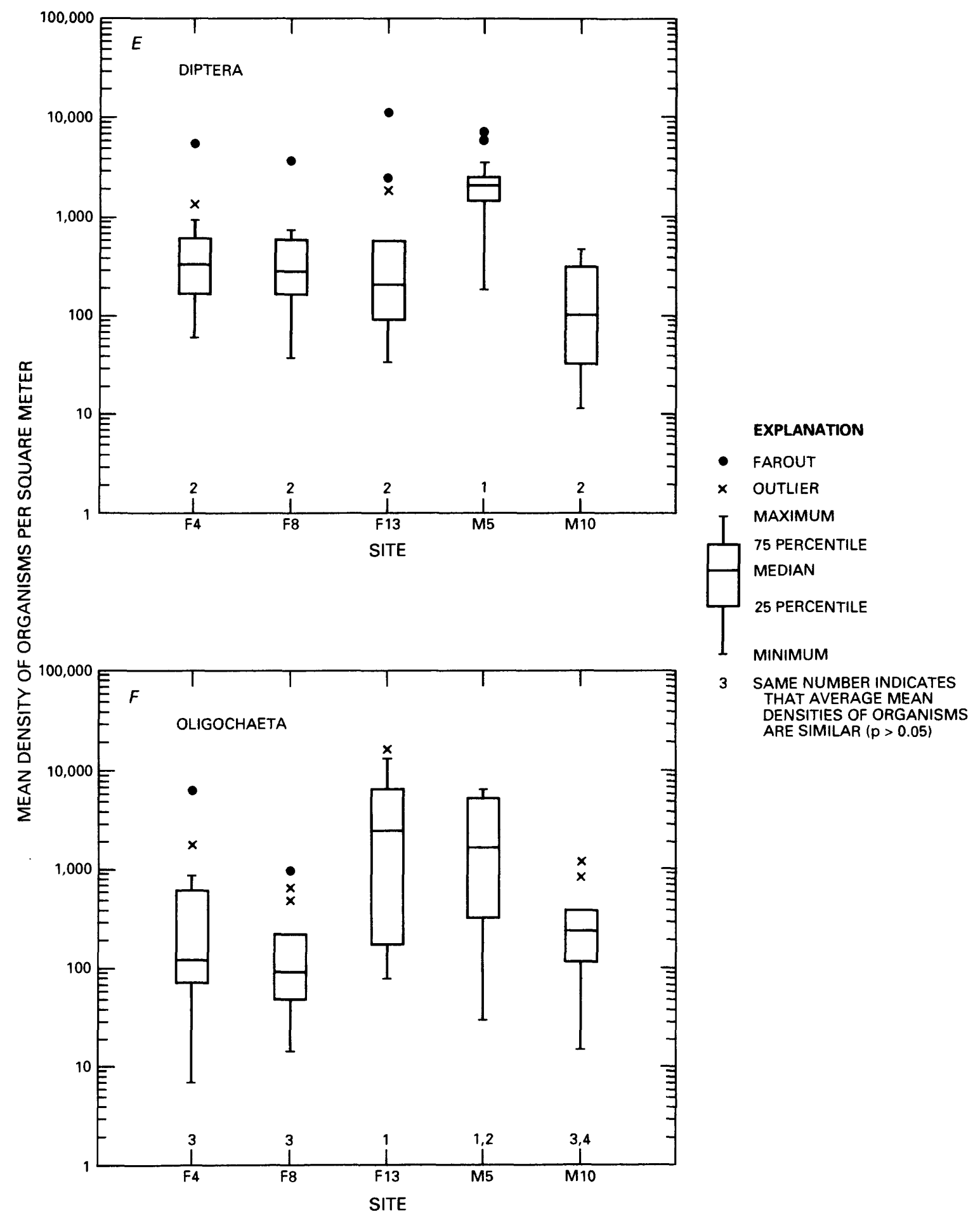

Figure 15.--Box plot of mean densities of organisms for all taxa and major taxonomic groups for benthic invertebrates collected on Fountain and Monument Creeks--Continued. 
Mean densities of organisms for all taxa were smallest at sites F8 and M10 (fig. 15A). The average mean densities of organisms for all taxa and for the major taxa groups, Plecoptera, Trichoptera, Diptera, and Oligochaeta, at sites F8 and M10 are similar (p>0.05) (fig. 15A,C-F). At sites F8 and M10, streamflow is affected by urbanization, and bed material mostly is sand and grave1 (table 16).

Sites $\mathrm{F} 4$ and M5 had the largest numbers of the more habitat-sensitive taxa, Ephemeroptera, Plecoptera, and Trichoptera (figs. 15B,C,D). Average mean densities of Ephemeroptera and Plecoptera at sites F4 and M5 were similar $(\mathrm{p}>0.05)$ (figs. 15B,C). Mean densities of Ephemeroptera, Plecoptera, and Trichoptera were smaller at sites F13 and M10 (figs. 15B,C,D). At sites F13 and M10, fluctuations in streambed elevations were more likely to occur (fig. 9, and fig. 20 in the "Supplemental Information" section at the back of this report), (table 8 ), and median $d_{50}$ of bed material was smallest. Sites F8, F13, and M10 had average mean densities of Plecoptera, Trichoptera, and Diptera that were similar $(\mathrm{p}>0.05)$ (figs. $15 C, D, E)$.

\section{Comparison with Other Studies}

Benthic-invertebrate samples were collected monthly from May 1979 through April 1980 at sites F4, F8, F13 and about $7 \mathrm{mi}$ upstream from site M5 (Colorado Springs Wastewater Division, 1980). The composition of benthic-invertebrate samples collected at these sites during 1979 and 1980 were similar to the present study. Site F4 and the site upstream from site M5 had the greatest number of taxa and the most abundant populations of Ephemeroptera, Plecoptera, and Trichoptera. Diptera and Oligochaeta were the most abundant organisms collected at sites F8 and F13. Ephemeroptera, Plecoptera, and Trichoptera rarely were collected at sites F8 and F13 (Colorado Springs Wastewater Division, 1980).

\section{EFFECTS OF SEDIMENT TRANSPORT ON BENTHIC INVERTEBRATES}

Stream habitat can be described by the water quality and physical characteristics of a stream. The occurrence and abundance of benthic invertebrates may be limited by: (1) Water quality (Roback, 1974; Pennak, 1978); (2) availability of suitable physical habitat as a function of type of bed material (Bell, 1968-69; Ward, 1975); and (3) stability of physical habitat as a function of bed-material size distribution and the occurrence of streamflows that can transport the bed material, thus causing disruption of the physical habitat (Molles, 1985; Sagar, 1986; S.P. Canton, Chadwick and Associates, Littleton, Colo., written commun., 1989).

By determining how much variance in benthic-invertebrate densities can be explained by certain stream-habitat characteristics, it may be possible to identify those characteristics that have the largest effect on benthicinvertebrate densities. The percent total variation in benthic-invertebrate densities that can be explained by stream-habitat characteristics is represented by $\mathrm{R}^{2}$ and is expressed as a percent. The RSQUARE procedure (Statistical Analysis System Institute, 1985, p. 711) was used to determine which stream-habitat characteristics explain the largest percent variation in benthic-invertebrate densities in Fountain and Monument Creeks. For a given 
sample, the RSQUARE procedure performs all possible subset linear regressions and finds the subsets of independent variables that best predict the dependent variable (Statistical Analysis System Institute, 1985). The best regression model was selected based on $\mathrm{R}^{2}$ and checked using other model-selection criteria (Statistical Analysis System Institute, 1985, p. 713). For the purposes of this analysis, only regression models that were significant (probability of a greater $\mathrm{F}<0.05$ ) and had independent variables that were significant in the regression model (probability of a greater $\mathrm{T}<0.05$ ) were used. Hydrologic data usually are skewed and do not have a normal distribution. Therefore, when using parametric statistical techniques, such as RSQUARE, data need to be transformed to approximate a normal distribution. Dependent and independent variables used in the RSQUARE procedure were log transformed (natural logarithm, base e).

Stream-habitat characteristics (independent variables) that were used as possible variables to explain variation in benthic-invertebrate populations were:

1. Water temperature, in degrees Celsius.

2. Specific conductance, in microsiemens per centimeter at 25 degrees Celsius.

3. $\mathrm{pH}$, in standard units.

4. Dissolved oxygen, in milligrams per liter.

5. Ammonium nitrogen $\left(\mathrm{NH}_{4}\right)$, in milligrams per liter.

6. Unionized ammonia nitrogen $\left(\mathrm{NH}_{3}\right)$, in milligrams per liter.

7. Median grain size of bed material sampled in conjunction with benthic-invertebrate samples, in millimeters.

8. Peak streamflow (flooding) during the 30 days prior to collection of benthic invertebrates. This was defined by using a dummy variable. Peak streamflows were considered to be streamflows large enough to substantially affect existing benthic-invertebrate densities (table 13). In some instances, peak streamflows substantially larger than those listed in table 13 that occurred more than 30 days prior to collection of benthic invertebrates were included in this analysis (table 13).

Water temperature, specific conductance, $\mathrm{pH}$, and dissolved oxygen were measured at the same time as benthic-invertebrate samples were collected. Ammonium nitrogen $\left(\mathrm{NH}_{4}\right)$ data were mean concentrations of samples collected periodically (monthly) at a sampling site prior to the collection of benthicinvertebrate samples. $\mathrm{NH}_{4}$ data were unavailable at Fountain Creek at Security (site F13). During December 1979 through September 1982, $\mathrm{NH}_{4}$ data were collected at Fountain Creek below Janitell road (site F8A) and Fountain Creek below Widefield (site F13A) (fig. 1). Site F8A is about $7.2 \mathrm{mi}$ upstream from site $\mathrm{F} 13$, and site $\mathrm{F} 13 \mathrm{~A}$ is about $1.5 \mathrm{mi}$ downstream from site $\mathrm{F} 13$. The ratio of $\mathrm{NH}_{4}$ concentrations (site $\mathrm{F} 13 \mathrm{~A} / \mathrm{site} \mathrm{F} 8 \mathrm{~A}$ ) was calculated for sites $\mathrm{F} 8 \mathrm{~A}$ and F13A. Water-quality samples, including analysis for $\mathrm{NH}_{4}$, were available at site F8A for the period of benthic-invertebrate sampling at site F13. To estimate $\mathrm{NH}_{4}$ concentrations at site $\mathrm{F} 13$ during benthic-invertebrate sampling, $\mathrm{NH}_{4}$ data at site $\mathrm{F} 8 \mathrm{~A}$ that corresponds to the benthic-invertebrate sampling period were multiplied by the median ratio $(0.67)$ of $\mathrm{NH}_{4}$ concentrations determined between sites F8A and F13A. Unionized ammonia $\left(\mathrm{NH}_{3}\right)$ was calculated at each site by using methods described by Skarheim (1973). For the purposes of this analysis, data for independent variables not collected during benthicinvertebrate sampling were estimated based on values of predictor variables collected for similar streamflow and sampling conditions. 
Table 13.--streamflows used to determine flooding during the 30 days prior to collection of benthic invertebrates

\begin{tabular}{|c|c|c|}
\hline $\begin{array}{l}\text { U.S. Geological } \\
\text { Survey station } \\
\text { number and site } \\
\text { number in figure } 1 \\
\text { and table } 1\end{array}$ & $\begin{array}{l}\text { Streamflows above which } \\
\text { existing benthic-invertebrate } \\
\text { densities were considered } \\
\text { to be substantially disturbed } \\
\text { (cubic feet per second) }\end{array}$ & $\begin{array}{l}\text { Number of times stream- } \\
\text { flows were exceeded } \\
\text { during the } 30 \text { days } \\
\text { prior to benthic- } \\
\text { invertebrate sampling }\end{array}$ \\
\hline 07103700 , site F4 & 100 & 3 \\
\hline 1,207105500, site $\mathrm{F} 8$ & 90 & 15 \\
\hline${ }^{1} 07105800$, site F13 & 200 & 15 \\
\hline 07103780, site M5 & 150 & 1 \\
\hline${ }^{1} 07104000$, site M10 & 50 & 14 \\
\hline
\end{tabular}

${ }^{1}$ Peak streamflows of $4,450 \mathrm{ft}^{3} / \mathrm{s}$ at site $\mathrm{F} 8,3,630 \mathrm{ft}^{3} / \mathrm{s}$ at site $\mathrm{F} 13$, and $2,750 \mathrm{ft}^{3} / \mathrm{s}$ at site M10 occurred 45 days prior to collection of benthic invertebrates.

${ }^{2}$ Peak streamflow of $927 \mathrm{ft}^{3} / \mathrm{s}$ occurred 32 days prior to collection of benthic invertebrates .

Streamflows large enough to disturb benthic-invertebrate densities substantially (table 13) were determined for each site based on the following analys is :

Fountain Creek near Colorado Springs (site F4):

At a streamflow of $122 \mathrm{ft}^{3} / \mathrm{s}$, particle size at threshold of movement ( $d_{c}$ in table 9) was near or exceeded the median $d_{50}$ of bed-material samples collected in conjunction with benthic-invertebrate samples (table 8 ). Sand is readily transported at most streamflows; however, sand composes generally less than 10 percent of bed material collected in conjunction with benthic-invertebrate samples (table 16 in the "Supplemental Information" section at the back of this report), the effects of streamflows less than $100 \mathrm{ft}^{3} / \mathrm{s}$ on benthic-invertebrate densities were considered minimal.

Fountain Creek at Colorado Springs (site F8), Fountain Creek at Security (site F13), and Monument Creek at Pikeview (site M10):

Because sand is readily available in bed material (table 16) and readily transported by most streamflows (table 9), benthic invertebrates present at these sites were assumed to be adapted to a shifting substrate type of habitat. Because of this assumption, it was difficult to quantify the magnitude of streamflows that cause significant disturbance of benthic-invertebrate densities.

Substantial disturbance of benthic invertebrates was assumed to occur when changes in streambed elevation was greater than $0.4 \mathrm{ft}$. Changes of about $0.4 \mathrm{ft}$ or more occurred between most of the crosssection surveys at these sites (table 18 in the "Supplemental Information" section at the back of this report). Examination of streamflow records indicated that these changes tended to occur when streamflows greater than twice the daily median streamflow occurred 
between consecutive cross-section surveys. For the purposes of this analysis, streamflows about 2 times the daily median streamflow for the period of study were considered to substantially disrupt benthicinvertebrate densities.

Monument Creek at USAFA (site M5):

Particle size at threshold of movement ( $d$ in table 9) did not exceed the median $d_{50}$ of bed material collected in conjunction with benthic-invertebrate samples ( $t a b l e ~ 8)$. However, bedload discharge at a streamflow larger than $150 \mathrm{ft}^{3} / \mathrm{s}$ was substantial (table 7) and was assumed to causes substantial changes in benthic-invertebrate densities. Sand is readily transported at most streamflows; however, sand generally composes less than 5 percent of bed material collected in conjunction with benthic invertebrates (table 16). The effects of streamflows less than $150 \mathrm{ft}^{3} / \mathrm{s}$ on benthic-invertebrate densities were considered minimal.

Results of application of the RSQUARE procedure to the Fountain and Monument Creeks data are summarized in table 14. Median grain size of bed material collected in conjunction with benthic-invertebrate samples and flooding during the 30 days prior to sampling were the most frequently occurring independent variables explaining the most variation in benthicinvertebrate densities during all sampling periods (table 14). Concentration of ammonium nitrogen was the most frequently occurring independent variable explaining the most variation in densities of 0ligochaetes during a11 sampling periods. Oligochaetes typically are bottom dwellers unaffected by size of bed material and are able to exist in a wide range of stream habitats (Pennak, 1978).

Median $\mathrm{d}_{50}$ of bed material collected in conjunction with benthicinvertebrate samples was largest at Fountain Creek near Colorado Springs (site F4) and Monument Creek at USAFA (site M5) (fig. 1; table 8). These sites consistently had the greatest number of taxa and, except for Oligochaetes at site F13, had the largest mean densities of benthic invertebrates (table 11 and table 19 in the "Supplemental Information" section at the back of this report). Sand is more common in bed material at Fountain Creek at Colorado Springs (site F8), Fountain Creek at Security (site F13), and Monument Creek at Pikeview (site M10) (table 16); these sites had less diverse taxa and, except for Oligochaetes at site F13, generally had small mean densities of benthic invertebrates (table 11). Sand affects the occurrence of benthic invertebrates by filling the interstices between the larger bed material, thus limiting available habitat. The filling of interstices may smother benthic invertebrates not adapted to a burrowing type of environment, such as most Ephemeroptera, Plecoptera, and Trichoptera. Also, the transport of sand abrades the coarser bed material and may cause increased mortality among benthic invertebrates. Bed-material conditions at Fountain Creek at Colorado Springs (site F8) may provide an example of how benthic invertebrates are affected by sand filling interstices and abrading coarser bed material. The median $d_{50}$ of bed material sampled in conjunction with benthic invertebrates at site F8 is less than, but similar, to the median $\mathrm{d}_{50}$ at sites $\mathrm{F} 4$ and M5 (table 8 ). However, the median percentage of sand (in the range of 0.062 to $2.0 \mathrm{~mm}$ ) determined in bed-material samples collected in conjunction with benthic-invertebrate samples is 13 at site F8 compared to 4 and 2 at sites F4 and M5. Benthic-invertebrate densities at site F8 usually were smaller than sites F4 and M5 (figs. 15A-F; table 11). 
Table 14.--Variation in total organisms and major taxa of benthic invertebrates accounted for by independent variables included in the best regression model for Fountain and Nonument Creoks

$\left[R^{2}\right.$, coefficient of determination; ${ }^{\circ} \mathrm{C}$, degrees Celsius; $\mu \mathrm{S} / \mathrm{cm}$, microsiemens per centimeter at 25 degrees Celsius; mg/L, milligrams per liter; $\mathrm{mm}$, millimeters; + , significant in regression model, positive correlation; -, significant in regression model, negative correlation; $*$, not significant]

\begin{tabular}{|c|c|c|c|c|c|c|c|c|c|}
\hline $\begin{array}{l}\text { (e) } \\
\text { as }\end{array}$ & $\begin{array}{c}\mathbf{R}^{2} \\
\text { xpressed } \\
\text { percent) }\end{array}$ & $\begin{array}{l}\text { Water } \\
\text { temper- } \\
\text { ature } \\
\left({ }^{\circ} \mathrm{C}\right)\end{array}$ & $\begin{array}{c}\text { Specific } \\
\text { conductance } \\
(\mu \mathrm{S} / \mathrm{cm})\end{array}$ & $\begin{array}{c}\mathrm{pH} \\
\text { (standard } \\
\text { units) }\end{array}$ & $\begin{array}{l}\text { Dissolved } \\
\text { oxygen } \\
(\mathrm{mg} / \mathrm{L})\end{array}$ & $\begin{array}{c}\text { Ammonium } \\
\text { nitrogen } \\
\text { total } \\
(\mathrm{mg} / \mathrm{L})\end{array}$ & $\begin{array}{l}\text { Un-ionized } \\
\text { ammonia } \\
\text { nitrogen } \\
\text { total } \\
\text { (mg/L) }\end{array}$ & $\begin{array}{l}\text { Median } \\
\text { grain size } \\
\text { of bed } \\
\text { material }\end{array}$ & $\begin{array}{l}\text { Flooding } \\
\text { during the } \\
30 \text { days } \\
\text { prior to } \\
\text { sampling }\end{array}$ \\
\hline \multicolumn{10}{|c|}{ ALL SAMPLING PERIODS } \\
\hline Total & 18 & * & * & $\hbar$ & $\frac{1}{\hbar}$ & * & * & + & * \\
\hline \multirow[t]{2}{*}{ organisms } & 30 & * & * & * & * & + & * & * & - \\
\hline & 35 & * & * & * & * & + & * & + & - \\
\hline \multirow[t]{4}{*}{ Ephemeroptera } & 46 & * & * & $\star$ & * & $\star$ & $*$ & + & * \\
\hline & 55 & * & * & * & * & * & * & + & - \\
\hline & 60 & + & $\star$ & * & * & * & $*$ & + & - \\
\hline & 62 & + & + & * & * & $\star$ & * & + & - \\
\hline \multirow[t]{2}{*}{ Plecopterat } & 34 & * & * & $\star$ & * & $\star$ & * & $\star$ & - \\
\hline & 37 & * & - & $\star$ & * & * & * & * & - \\
\hline \multirow[t]{3}{*}{ Trichoptera } & 45 & * & * & * & $\star$ & $\star$ & $\star$ & $\star$ & - \\
\hline & 52 & * & $\star$ & * & * & * & * & + & - \\
\hline & 56 & $\star$ & * & + & * & * & * & + & - \\
\hline Diptera & 22 & * & * & * & * & * & * & + & * \\
\hline Oligochaeta & 25 & $\star$ & * & * & $*$ & + & $\star$ & $\star$ & * \\
\hline \multicolumn{10}{|c|}{ SPRING (APRIL) } \\
\hline Total & 27 & * & $\star$ & $\hbar$ & * & $\star$ & * & + & * \\
\hline organisms & 48 & * & $\star$ & * & $\star$ & * & + & * & - \\
\hline Ephemeroptera & 41 & * & * & * & * & * & * & + & * \\
\hline Plecoptera & 43 & * & * & * & * & * & * & * & - \\
\hline \multirow{3}{*}{ Trichoptera } & 46 & * & * & * & $\star$ & $\star$ & * & + & $\star$ \\
\hline & 61 & * & * & * & + & * & * & + & * \\
\hline & 74 & * & * & * & + & + & * & + & * \\
\hline \multirow[t]{2}{*}{ Diptera } & 40 & * & * & * & * & * & * & + & * \\
\hline & 49 & $\star$ & + & $\star$ & $\star$ & * & * & * & - \\
\hline \multirow[t]{2}{*}{ Oligochaeta } & 40 & $\star$ & $\star$ & $\star$ & $\star$ & + & $\star$ & * & $\star$ \\
\hline & \multicolumn{9}{|c|}{ EARLY SUMMER (LATE JUNE-EARLY JULY) } \\
\hline Total & 44 & * & * & $\hbar$ & $\frac{1}{\star}$ & * & * & * & - \\
\hline organisms & 66 & * & $\star$ & * & - & * & * & * & - \\
\hline Ephemeroptera & 71 & $\star$ & * & $\star$ & $\star$ & * & * & * & - \\
\hline Plecoptera & 40 & - & * & * & $\star$ & $\star \star$ & * & * & * \\
\hline \multirow[t]{2}{*}{ Trichoptera } & 70 & $\star$ & $*$ & $\star$ & $\star$ & $\star$ & * & * & - \\
\hline & 77 & * & $\star$ & * & * & * & * & + & - \\
\hline \multirow{2}{*}{ Diptera } & 32 & * & $\star$ & * & * & $\star$ & * & * & - \\
\hline & 47 & + & * & * & $\star$ & * & * & * & - \\
\hline \multirow[t]{2}{*}{ Oligochaeta } & 22 & $\star$ & $\star$ & $\star$ & $\star$ & $\star$ & * & $\star$ & - \\
\hline & 52 & $\star$ & $*$ & $*$ & $\star$ & $\star$ & + & * & - \\
\hline \multicolumn{10}{|c|}{ LATE SUMER (LATE AUGUST-EARLY SEPTEMBER) } \\
\hline Total & * & * & $*$ & * & $\hbar$ & 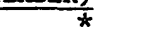 & $\star$ & $\star$ & $\star$ \\
\hline organisms & & & & & & & & & \\
\hline Ephemeroptera & 50 & $\star$ & * & * & * & * & * & + & * \\
\hline & 68 & $\star$ & - & * & * & * & * & + & $\star$ \\
\hline Plecoptera & 43 & $\star$ & - & * & $\star$ & $\star$ & $\star$ & * & * \\
\hline & 65 & * & - & * & * & * & * & + & * \\
\hline Trichoptera & 40 & * & - & * & * & * & * & * & * \\
\hline Diptera & $\star$ & $\star$ & * & * & $\star$ & * & * & * & * \\
\hline Oligochaeta & 30 & * & * & * & * & + & * & * & * \\
\hline & & & FALI & (LATE OCTO & -EARLY NOVE & & & & \\
\hline Total & 33 & - & $*$ & * & $\star$ & * & * & $\star$ & $\star$ \\
\hline organisms & 58 & - & $\star$ & * & * & + & * & * & * \\
\hline & 71 & - & $*$ & + & * & + & * & * & * \\
\hline Ephemeroptera & 66 & * & * & * & $*$ & $*$ & * & + & * \\
\hline Plecoptera & 64 & $\star$ & - & $\star$ & $\star$ & $\star$ & * & $\star$ & * \\
\hline Trichoptera & 69 & * & - & * & * & * & * & * & * \\
\hline & 82 & - & - & * & * & * & * & * & * \\
\hline Diptera & 48 & - & * & * & $\star$ & $\star$ & * & * & $\star$ \\
\hline Oligochaeta & 33 & $\star$ & * & * & * & + & * & * & * \\
\hline
\end{tabular}


Flooding during the 30 days prior to sampling was the most frequently occurring independent variable explaining the most variation in benthicinvertebrate densities during early summer (table 14). Sagar (1986) reported that benthic-invertebrate abundance was inversely related to antecedent ( 30 days prior to sampling) streamflows. Molles (1985) reported that a single flood caused decreases in total densities of benthic invertebrates in a stream in northern New Mexico and that after 9 months, densities of benthic invertebrates were substantially smaller at the disturbed sites than at an undisturbed sampling site.

Streamflows large enough to substantially disturb benthic-invertebrate densities occurred most frequently at sites F8, F13, and M10 (table 13). During flooding, most of the bottom material at sites $F 13$ and $M 10$ is readily transported. Although the particle size at threshold of movement (table 9) is less than the median $d_{50}$ of bed material collected in conjunction with benthic-invertebrate samples (table 8), the transport of sand during periods of flooding may affect benthic-invertebrate densities at site F8. The large changes in streambed elevation measured at these sites (table 18) indicate the habitat disruption that results from flooding.

During the late summer, no significant (probability of a greater $\mathrm{T}<0.05$ ) independent variables were identified for total number of organisms or for total number of Diptera organisms. During the late summer and fall, there were no independent variables that consistently explained the variation in benthic-invertebrate densities. Disruption of benthic-invertebrate densities as a result of flooding during spring and early summer may explain the absence of any consistent independent variables during the late summer and fall.

This analysis did not include any study of toxic chemical constituents. How the presence or absence of such toxic substances affect benthicinvertebrate densities was not determined.

\section{SUMMARY AND CONCLUSIONS}

The smallest median suspended-sediment concentrations were determined for suspended-sediment samples collected at Monument Creek at Palmer Lake (site M1) and Monument Creek at U.S. Air Force Academy (site M5). These sites are located in the headwater parts of Monument Creek. Maximum and median suspended-sediment concentrations were largest at Fountain Creek near Colorado Springs (site F4) and Monument Creek at Bijou Street at Colorado Springs (site M16). Median values for percentage of suspended sediment finer than $0.062 \mathrm{~mm}$ ranged from 55 to 69 percent. Most of the suspended sand in transport during snowmelt and rainfall runoff is very fine to fine. Silt composed from 23 to 61 percent of suspended sediment. Coarse clay and suspended sediments finer than $0.002 \mathrm{~mm}$ composed 11 to 62 percent of the suspended sediment.

Mean annual suspended-sediment yield increased about 73 percent between Fountain Creek near Colorado Springs (site F4) and Fountain Creek at Colorado Springs (site F8). Suspended-sediment discharge at site F8 is affected greatly by suspended-sediment discharge from Monument Creek, the main tributary to Fountain Creek. Mean annual suspended-sediment yields decreased about 30 percent between sites $\mathrm{F} 8$ and $\mathrm{F} 13$. 
Mean annual suspended-sediment yield increased about 20 percent between Monument Creek at Palmer Lake (site M1) and Monument Creek at USAFA (site M5). Between site M5 and Monument Creek at Pikeview (site M10), mean annual suspended-sediment yield increased about 608 percent.

The median grain size of all bed-material samples was very coarse sand to small cobbles. The median grain size of all bedload samples was coarse sand to very fine gravel.

Bedload discharge was computed at six of the periodic sampling sites. Measured bedload discharge ranged from 2.6 to 3,570 tons per day. Bedload discharge, as a percentage of total sediment discharge, is smallest during periods of rainfall runoff, ranging from 6 to 30 percent. During periods of rainfall runoff, fine sediments are introduced into streams by erosion resulting from rain splash and surface runoff. Bedload discharge, as a percentage of total sediment discharge during snowmelt runoff, ranged from 16 to 90 percent.

Fountain and Monument Creeks are capable of transporting most of the bed-material grain sizes sampled. The range of particle sizes at threshold of movement represented small to moderate streamflows. The upper limit of particle sizes at threshold of movement would be larger for higher streamflows.

Sites F4 and M5 have stable streambeds with little or no change in streambed elevation measured. Sites F8, F13, and M10 have mobile streambeds with changes in streambed elevation commonly measured between consecutive stream-channel cross-section surveys.

Benthic invertebrates were collected four times annually, except during 1988, when they were collected only three times. Number of taxa, species density, and similarity indices were determined at five of the periodic sampling sites. At the five benthic-invertebrate sampling sites, 138 taxa were identified; however, only 24 were common to all sites. Total number of taxa identified were 81 at site F4, 63 at site F8, 55 at site $F 13,78$ at site M5, and 41 at site M10. The more habitat-sensitive taxa, Ephemeroptera, Plecoptera, and Trichoptera were most abundant and were more frequently collected at sites F4 and M5. Evaluation of similarity indices and percent similarity between all sites indicated that sites $F 8$ and M10 were most similar, and sites F4 and M5 were most similar.

The average mean densities of total number of organisms at sites $F 13$ and M5 were similar $(p>0.05)$. Sites F13 and M5 represented the extremes in instream-habitat conditions in the study area with respect to stability of streambed and variability of streamflow. The similarity of average mean densities of total number of organisms is a result of the large numbers of Oligochaetes collected at sites F13 and M5. 0ligochaetes are able to exist in a wide range of habitats as opposed to the more habitat-sensitive taxa of Ephemeroptera, Plecoptera, and Trichoptera. Oligochaeta is the only major taxa group for which mean densities of organisms were similar between sites F13 and M5. The more habitat-sensitive-taxa Ephemeroptera, Plecoptera, and Trichoptera were substantially more abundant at site M5. 
Mean densities of total number of organisms were smallest at sites $\mathrm{F} 8$ and M10. The average mean densities of total number of organisms at sites $\mathrm{F} 8$ and M10 were similar $(\mathrm{p}>0.05)$. Bed material at sites $F 8$ and M10 is mostly sand and gravel.

Average mean densities of Ephemeroptera and Plecoptera at sites F4 and M5 were similar $(p>0.05)$. Mean densities of Ephemeroptera, Plecoptera, and Trichoptera were smaller at sites F13 and M10 than at sites F4 and M5. At sites F13 and M10, fluctuations in streambed elevations were more likely to occur, and median $d_{50}$ of bed material was smaller. Sites F8, F13, and M10 had average mean densities of Plecoptera, Trichoptera, and Diptera that were similar $(\mathrm{p}>0.05)$.

Median diameter of bed material that was collected in conjunction with benthic-invertebrate samples and flooding that occurred 30 days prior to sampling consistently explained the most variation in benthic-invertebrate densities during all sampling periods. Concentrations of ammonium nitrogen consistently explained the most variation in densities of Oligochaetes during all sampling periods. Oligochaetes typically are bottom dwellers unaffected by size of bed material and are able to exist in a wide range of stream habitats. Flooding during the 30 days prior to sampling consistently explained the most variation in benthic-invertebrate densities during early summer.

During late summer, no significant (probability of a greater $\mathrm{T}<0.05$ ) independent variables were identified for total number of organisms or for total number of Diptera organisms. During late summer and fall, there were no independent variables that consistently explained the variation in benthicinvertebrate densities. Disruption of benthic-invertebrate densities, as a result of flooding (during spring and early summer), may explain the absence of any consistent predictor variables during late summer and fall.

This analysis did not include any study of toxic chemical constituents. How the presence or absence of such toxic substances affects benthicinvertebrate densities was not determined.

\section{REFERENCES CITED}

Andrews, E.D., 1983, Entrainment of gravel from naturally sorted riverbed material: Geological Society of America Bulletin, v. 94, p. 1225-1231.

Bell, H.L., 1968-69, Effect of substrate types on aquatic insect distribution: Journal of Minnesota Academy of Science, v. 35, p. 79-81.

Britton, L.J., and Greeson, P.E., editors, 1989, Methods for collection and analysis of biological and microbiological samples: U.S. Geological Survey Techniques of Water-Resources Investigations, bk. 5, chap. A4, $363 \mathrm{p}$.

Canton, S.P. and Chadwick, J.W., 1988, Variability in benthic invertebrate density estimates from stream samples: Journal of Freshwater Ecology, v. 4 no. 3. p. 291-298.

Canton, S.P., Cline, L.D., Short, R.A., and Ward, J.V., 1984, The macroinvertebrates of a Colorado stream during a period of fluctuating discharge: Freshwater Biology, v. 14, p. 311-316. 
Chapman, H.H., 1933, Influence of overgrazing on erosion and watersheds: Civil Engineering, v. 3, no. 2, p. 74-78.

Cohn, T.A., Delong, L.L., Gilroy, E.J., Hirsch, R.M., and Wells, D.K., 1989, Estimating constituent loads: Water Resources Research, v. 25, no. 5, p. 937-942.

Colby, B.R., 1957, Relationship of unmeasured sediment discharge to mean velocity: American Geophysical Union Transactions, v. 38, no. 5, p. 708-717.

Colby, B.R., and Hubbell, D.W., 1961, Simplified methods for computing total sediment discharge with the modified Einstein procedure: U.S. Geological Survey Water-Supply Paper 1593, 17 p.

Colorado Climate Center, 1984, Colorado average precipitation map 1951-1980: Fort Collins, Colo., scale 1:500,000.

Colorado Springs Wastewater Division, 1980, Colorado Springs Wastewater division stream study: Colorado Springs, Colo., unpublished report, 129 p.

Conover, W.J. and Iman, R.L., 1981, Rank transformations as a bridge between parametric and non-parametric statistics: The American Statistician, v. 35, no. 3, p. 124-129.

Edwards, T.K., and Glysson, G.D., 1988, Field methods for measurement of fluvial sediment: U.S. Geological Survey Open-File Report 86-531, 118 p.

E1liott, J.G., and DeFeyter, K.L., 1986, Sediment-data sources and estimated annual suspended-sediment loads of rivers and streams in Colorado: U.S. Geological Survey Water-Resources Investigations Report 84-4141, $44 \mathrm{p}$.

Elliott, J.G., Kircher, J.E., and von Guerard, Paul, 1984, Sediment transport in the lower Yampa River, northwestern Colorado: U.S. Geological Survey Water-Resources Investigations Report 84-4141, $44 \mathrm{p}$.

Emmett, W.W., 1980, A field calibration of the sediment-trapping characteristics of the Helley-Smith bedload sampler: U.S. Geological Survey Professional Paper 1139, 44 p.

Glysson, G.D., 1987, Sediment transport curves: U.S. Geological Survey Open-File Report 87-218, 47 p.

Guy, H.P., 1969, Laboratory theory and methods for sediment analysis: U.S. Geological Survey Techniques of Water Resources Investigations, bk. 3 chap. $\mathrm{C} 1,58 \mathrm{p}$.

Guy, H.P., and Norman, V.W., 1970, Field methods for measurement of fluvial sediment: U.S. Geological Survey Techniques of Water-Resources Investigations, bk. 3, chap. C2, 59 p.

Helley, E.J., and Smith, Winchel1, 1971, Development and calibration of a pressure-difference bedload sampler: U.S. Geological Survey Open-File Report 73-108, $38 \mathrm{p}$.

Kircher, J.E., 1982, Sediment transport and source areas of sediment and runoff, Big Sandy River basin, Wyoming: U.S. Geological Survey WaterResources Investigations Report 81-72, 51 p. [Available only from National Technical Information Service, Springfield, Va., as PB-82 215 898].

Kuhn, Gerhard, 1988, Methods to determine transit losses for return flows of transmountain water in Fountain Creek between Colorado Springs and the Arkansas River, Colorado: U.S. Geological Survey Water-Resources Investigations Report 87-4119, $183 \mathrm{p}$.

Martin, J.D., and Crawford, C.G., 1987, Statistical analysis of surfacewater-quality data in and near the coal-mining region of southwestern Indiana, 1957-80: U.S. Geological Survey Water-Supply Paper 2291, 92 p. 
Meffe, G.K. and Minckley, W.L., 1986, Persistence and stability of fish and invertebrate assemblages in a repeatedly disturbed sonoran desert stream: The American Midland Naturalist, v. 117, no. 1, p. 177-191.

Merritt, R.W., and Cummins, K.W., 1984, An introduction to the aquatic insects of North America (2d ed.): Dubuque, Iowa, Kendall and Hunt, 722 p.

Miller, D.M., 1984, Reducing transformation bias in curve fitting: The American Statistician, v., 38, no. 2, p. 124-126.

Molles, M.C., 1985, Recovery of a stream invertebrate community from a flash flood in Tesuque Creek, New Mexico: The Southwestern Naturalist, v. 30 (2), p. 279-287.

Odum, E.P., 1971, Fundamentals of ecology (3d ed.): Philadelphia, W.B. Saunders Co., 574 p.

Pennak, R.W., 1978, Freshwater invertebrates of the United States (2d ed.): New York, John Wiley and Sons, 803 p.

Roback, S.S., 1974, Insects (Arthropoda: Insecta), in Hart, C.W., Jr., and Fuller, S.L.H., eds., Pollution ecology of fresh water invertebrates: New York, Academic Press, p. 313-376.

Sagar, P.M., 1986, The effects of floods on the invertebrate fauna of a large, unstable braided river: New Zealand Journal of Marine Research, v. 20, no. 1, p. 37-46.

Shields, A., 1936, "Anwendung der Achnlichkeitsmechanik und Turbulenz forschung auf die Geschiebewegung," Mitteilung Preussischen Versuchanstalt Wasser, Erd, Schiffbau, Berlin, No. 26 (in German).

Skarheim, H.P., 1973, Tables of the fraction of ammonia in the undissociated form for $\mathrm{pH} 6$ to 9, temperature 0-30 degrees Celsius, total dissolved solids $0-3000 \mathrm{mg} / \mathrm{L}$, and salinity $5-35 \mathrm{~g} / \mathrm{kg}$ : Berkeley, University of California, Sanitary Engineering Research Laboratory, SERL Report No. $73-5,33 \mathrm{p}$.

Statistical Analysis System Institute, 1985, SAS users guide--statistics (5th ed.): Carey, N.C., SAS Institute, Inc., 956 p.

U.S. Geological Survey, 1970, The National Atlas of the United States of America: Washington, D.C., 335 p.

Von Guerard, Paul, 1989, Suspended sediment and sediment-source areas in the Fountain Creek drainage basin upstream from Widefield, southeastern Colorado: U.S. Geological Survey Water-Resources Investigations Report $88-4136,36 \mathrm{p}$.

Ward, J.V., 1975, Bottom fauna-substrate relationships in a northern Colorado trout stream: 1945 and 1974, Ecology, v. 56, no. 6, p. 1429-1434.

Whittaker, R.H., 1975, Communities and ecosystems (2d ed.): New York, MacMillan Publishing Co., Inc., 385 p.

Williams, R.P., and Krupin, P.J., 1984, Erosion, channel change, and sediment transport in the Big Lost River, Idaho: U.S. Geological Survey WaterResources Investigations Report 84-4147, $87 \mathrm{p}$. 
SUPPLEMENTAL INFORMATION 
Table 15.--suspended-sediment size distribution for samples collected during snowmelt and rainfall rumoff for selected sites on Fountain and Nonument Creeks, water years 1985-88

[mm, millimeters; mg/L, milligrams per liter; NA, not applicable; --, indicates no data]

\begin{tabular}{|c|c|c|c|c|c|c|c|c|c|c|c|}
\hline \multirow[b]{2}{*}{ Date } & \multicolumn{9}{|c|}{ Percentage of suspended } & \multirow[b]{2}{*}{$\begin{array}{c}\text { Suspended- } \\
\text { sediment } \\
\text { concentration } \\
(m g / L)\end{array}$} & \multirow[b]{2}{*}{$\begin{array}{c}\text { Steamflow } \\
\text { (cubic feet } \\
\text { per } \\
\text { second) }\end{array}$} \\
\hline & $\begin{array}{c}1.00 \\
\mathrm{~mm} \\
\text { (per- } \\
\text { cent) }\end{array}$ & $\begin{array}{l}0.50 \\
\mathrm{~mm} \\
\text { (per- } \\
\text { cent) }\end{array}$ & $\begin{array}{l}0.25 \\
\text { min } \\
\text { (per- } \\
\text { cent) }\end{array}$ & $\begin{array}{l}0.125 \\
\text { mm } \\
\text { (per- } \\
\text { cent) }\end{array}$ & $\begin{array}{l}0.062 \\
\text { (pm } \\
\text { cent) }\end{array}$ & $\begin{array}{l}0.016 \\
\text { (pin } \\
\text { cent) }\end{array}$ & $\begin{array}{c}0.008 \\
\text { (per- } \\
\text { cent) }\end{array}$ & $\begin{array}{c}0.004 \\
\mathrm{~mm} \\
\text { (per- } \\
\text { cent) }\end{array}$ & $\begin{array}{l}0.002 \\
\text { (pm } \\
\text { cent) }\end{array}$ & & \\
\hline
\end{tabular}

07103700 FOUNTAIN CREEK NEAR COLORADO SPRINGS (SITE F4)

\begin{tabular}{|c|c|c|c|c|c|c|c|c|c|c|c|}
\hline $\begin{array}{l}04-04-85 \\
04-18-85 \\
04-30-85 \\
04-29-87\end{array}$ & $\begin{array}{l}\text { NA } \\
99 \\
\text { NA } \\
\text { NA }\end{array}$ & $\begin{array}{r}\text { NA } \\
99 \\
100 \\
100\end{array}$ & $\begin{array}{l}\text { NA } \\
94 \\
96 \\
98\end{array}$ & $\begin{array}{r}100 \\
85 \\
89 \\
85\end{array}$ & $\begin{array}{l}94 \\
73 \\
81 \\
67\end{array}$ & $\begin{array}{l}-- \\
41 \\
60 \\
--\end{array}$ & $\begin{array}{l}-- \\
-- \\
--\end{array}$ & $\begin{array}{l}-- \\
26 \\
40 \\
--\end{array}$ & $\begin{array}{l}-- \\
25 \\
31 \\
--\end{array}$ & $\begin{array}{r}42 \\
93 \\
4,900 \\
157\end{array}$ & $\begin{array}{r}22 \\
35 \\
122 \\
24\end{array}$ \\
\hline
\end{tabular}

07105500 FOUNTAIN CREEK AT COLORADO SPRINGS (SITE F8)

\begin{tabular}{|c|c|c|c|c|c|c|c|c|c|c|c|}
\hline $\begin{array}{l}04-04-85 \\
05-03-85 \\
05-01-87 \\
06-23-88\end{array}$ & $\begin{array}{l}\text { NA } \\
100 \\
100 \\
100\end{array}$ & $\begin{array}{r}100 \\
99 \\
97 \\
98\end{array}$ & $\begin{array}{l}95 \\
87 \\
80 \\
90\end{array}$ & $\begin{array}{l}88 \\
59 \\
65 \\
77\end{array}$ & $\begin{array}{l}78 \\
39 \\
56 \\
67\end{array}$ & $\begin{array}{l}58 \\
22 \\
40 \\
51\end{array}$ & $\begin{array}{l}-- \\
-- \\
-- \\
45\end{array}$ & $\begin{array}{l}37 \\
13 \\
26 \\
38\end{array}$ & $\begin{array}{l}28 \\
10 \\
19 \\
31\end{array}$ & $\begin{array}{r}1,130 \\
2,210 \\
434 \\
3,890\end{array}$ & $\begin{array}{l}115 \\
526 \\
131 \\
234\end{array}$ \\
\hline
\end{tabular}

07105800 FOUNTAIN CREEK AT SECURITY (SITE F13)

\begin{tabular}{|c|c|c|c|c|c|c|c|c|c|c|c|}
\hline $\begin{array}{l}04-04-85 \\
05-03-85 \\
05-01-87 \\
06-08-87 \\
08-26-87\end{array}$ & $\begin{array}{r}\text { NA } \\
\text { NA } \\
100 \\
99 \\
100\end{array}$ & $\begin{array}{r}100 \\
100 \\
94 \\
98 \\
99\end{array}$ & $\begin{array}{l}92 \\
87 \\
80 \\
95 \\
92\end{array}$ & $\begin{array}{l}83 \\
64 \\
68 \\
86 \\
78\end{array}$ & $\begin{array}{l}74 \\
44 \\
58 \\
69 \\
64\end{array}$ & $\begin{array}{l}55 \\
26 \\
42 \\
50 \\
49\end{array}$ & $\begin{array}{l}-- \\
-- \\
-- \\
43 \\
41\end{array}$ & $\begin{array}{l}42 \\
15 \\
28 \\
35 \\
34\end{array}$ & $\begin{array}{l}28 \\
11 \\
21 \\
28 \\
28\end{array}$ & $\begin{array}{r}993 \\
2,280 \\
494 \\
22,700 \\
8,460\end{array}$ & $\begin{array}{r}197 \\
633 \\
170 \\
2,680 \\
1,350\end{array}$ \\
\hline $\begin{array}{l}08-26-87 \\
06-15-88 \\
08-09-88 \\
08-09-88 \\
08-09-88\end{array}$ & $\begin{array}{r}100 \\
\text { NA } \\
100 \\
\text { NA } \\
100\end{array}$ & $\begin{array}{r}97 \\
100 \\
99 \\
100 \\
99\end{array}$ & $\begin{array}{l}91 \\
99 \\
96 \\
95 \\
96\end{array}$ & $\begin{array}{l}80 \\
94 \\
82 \\
84 \\
85\end{array}$ & $\begin{array}{l}69 \\
89 \\
67 \\
70 \\
74\end{array}$ & $\begin{array}{l}58 \\
80 \\
49 \\
54 \\
60\end{array}$ & $\begin{array}{l}52 \\
73 \\
42 \\
46 \\
53\end{array}$ & $\begin{array}{l}44 \\
62 \\
35 \\
39 \\
46\end{array}$ & $\begin{array}{l}36 \\
50 \\
28 \\
31 \\
39\end{array}$ & $\begin{array}{r}3,730 \\
2,150 \\
16,800 \\
14,000 \\
8,380\end{array}$ & $\begin{array}{r}550 \\
150 \\
3,000 \\
2,520 \\
911\end{array}$ \\
\hline
\end{tabular}

07103780 MONUMENT CREEK ABOVE NORTH GATE BOULEVARD AT U.S. AIR FORCE ACADEMY (SITE M5)

\begin{tabular}{|c|c|c|c|c|c|c|c|c|c|c|c|}
\hline $\begin{array}{l}04-18-85 \\
05-03-85 \\
04-30-87\end{array}$ & $\begin{array}{r}\text { NA } \\
100 \\
\text { NA }\end{array}$ & $\begin{array}{r}100 \\
97 \\
--\end{array}$ & $\begin{array}{r}85 \\
75 \\
100\end{array}$ & $\begin{array}{l}62 \\
49 \\
98\end{array}$ & $\begin{array}{l}45 \\
34 \\
93\end{array}$ & $\begin{array}{l}29 \\
19 \\
60\end{array}$ & $\begin{array}{l}-- \\
--\end{array}$ & $\begin{array}{l}17 \\
11 \\
32\end{array}$ & $\begin{array}{r}16 \\
8 \\
20\end{array}$ & $\begin{array}{r}330 \\
1,060 \\
151\end{array}$ & $\begin{array}{r}62 \\
199 \\
33\end{array}$ \\
\hline
\end{tabular}

07104000 MONUMENT CREEK AT PIKEVIEW (SITE M10)

\begin{tabular}{|c|c|c|c|c|c|c|c|c|c|c|c|}
\hline $\begin{array}{l}04-03-85 \\
05-02-85 \\
04-29-87\end{array}$ & $\begin{array}{r}\text { NA } \\
100 \\
\text { NA }\end{array}$ & $\begin{array}{r}100 \\
98 \\
100\end{array}$ & $\begin{array}{l}97 \\
90 \\
97\end{array}$ & $\begin{array}{l}88 \\
65 \\
87\end{array}$ & $\begin{array}{l}73 \\
40 \\
76\end{array}$ & $\begin{array}{l}49 \\
22 \\
52\end{array}$ & $=$ & $\begin{array}{l}32 \\
13 \\
38\end{array}$ & $\begin{array}{l}28 \\
10 \\
30\end{array}$ & $\begin{array}{r}1,030 \\
2,720 \\
449\end{array}$ & $\begin{array}{r}57 \\
321 \\
72\end{array}$ \\
\hline
\end{tabular}

07104905 MONUMENT CREEK AT BIJOU STREET AT COLORADO SPRINGS (SITE M16)

\begin{tabular}{|c|c|c|c|c|c|c|c|c|c|c|c|}
\hline $\begin{array}{l}04-03-85 \\
05-02-85 \\
04-30-87\end{array}$ & $\begin{array}{r}\text { NA } \\
100 \\
\text { NA }\end{array}$ & $\begin{array}{r}100 \\
99 \\
100\end{array}$ & $\begin{array}{l}95 \\
91 \\
94\end{array}$ & $\begin{array}{l}87 \\
69 \\
80\end{array}$ & $\begin{array}{l}79 \\
45 \\
66\end{array}$ & $\begin{array}{l}61 \\
25 \\
47\end{array}$ & $\begin{array}{l}-\infty \\
--\end{array}$ & $\begin{array}{l}40 \\
16 \\
32\end{array}$ & $\begin{array}{l}34 \\
13 \\
24\end{array}$ & $\begin{array}{r}1,270 \\
3,450 \\
482\end{array}$ & $\begin{array}{r}58 \\
346 \\
77\end{array}$ \\
\hline
\end{tabular}


Table 16.--Bed-material size distribution for selected sites on Fountain and Monument Creeks, water years $1985-88$

[mm, millimeters; --, not applicable]

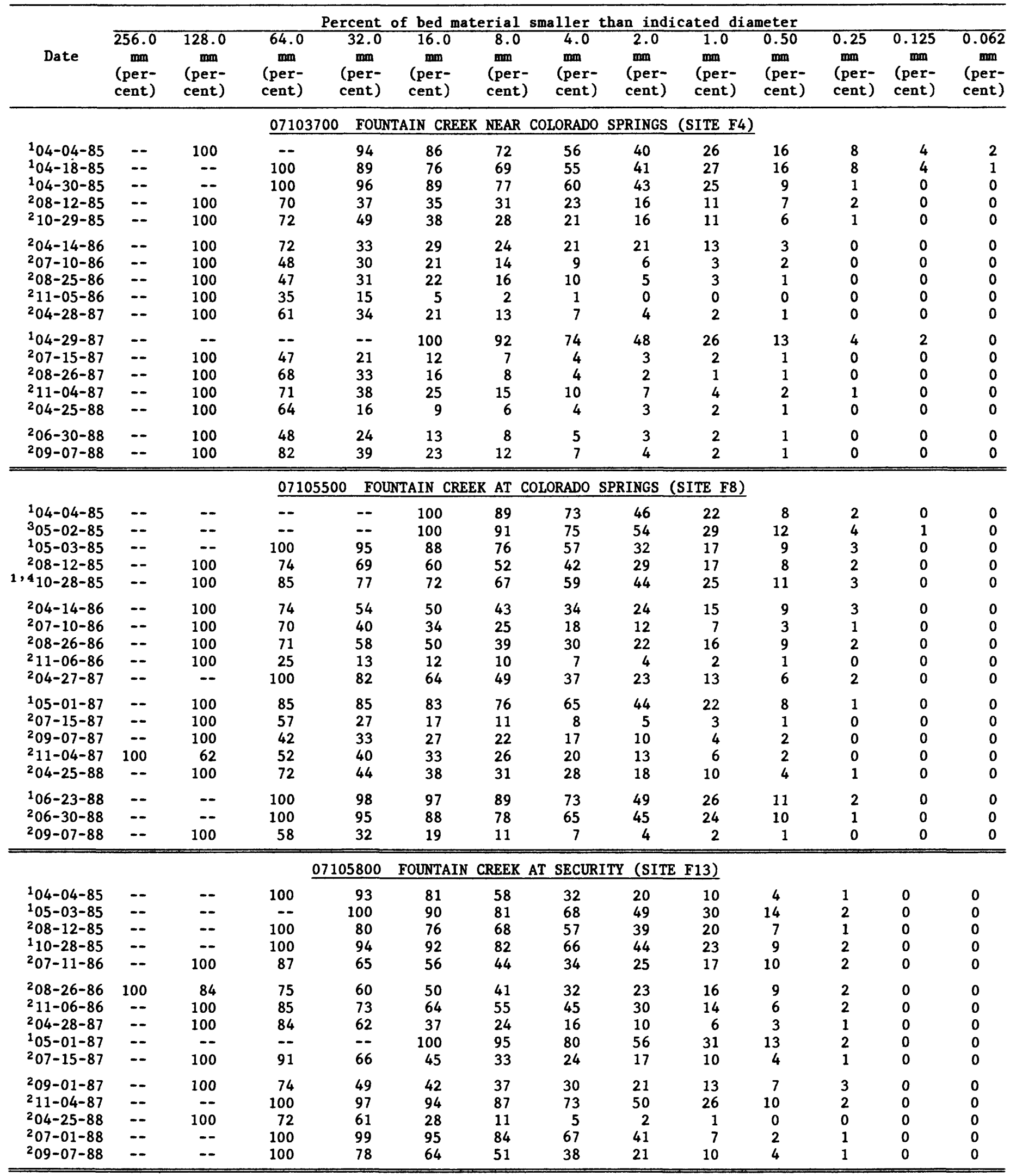


Table 16.--Bed-material size distribution for selected sites on Fountain and Monument Creeks, water years 1985-88--Continued

\begin{tabular}{|c|c|c|c|c|c|c|c|c|c|c|c|c|c|}
\hline \multirow[t]{2}{*}{ Date } & $\begin{array}{c}256.0 \\
\text { mm } \\
\text { (per- } \\
\text { cent) }\end{array}$ & $\begin{array}{c}128.0 \\
\text { mm } \\
\text { (per- } \\
\text { cent) }\end{array}$ & $\begin{array}{c}64.0 \\
\text { min } \\
\text { (per- } \\
\text { cent) }\end{array}$ & $\begin{array}{r}\begin{array}{c}\text { Percent } \\
32.0 \\
\text { mm } \\
(\text { per- } \\
\text { cent) }\end{array} \\
\end{array}$ & $\frac{\text { of bed } \mathrm{m}}{16.0} \begin{array}{c}\mathrm{mm} \\
\text { (per- } \\
\text { cent) }\end{array}$ & $\begin{array}{c}\text { material s } \\
8.0 \\
\text { (per- } \\
\text { cent) }\end{array}$ & $\begin{array}{c}\text { aller } \\
4.0 \\
\operatorname{mm} \\
(\text { per- } \\
\text { cent) }\end{array}$ & 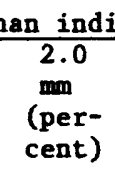 & 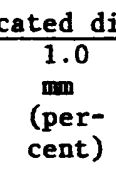 & $\begin{array}{c}\text { iameter } \\
0.50 \\
\mathrm{~mm} \\
(\text { per- } \\
\text { cent) }\end{array}$ & $\begin{array}{c}0.25 \\
\text { mm } \\
\text { (per- } \\
\text { cent) }\end{array}$ & $\begin{array}{c}0.125 \\
\mathrm{~mm} \\
\text { (per- } \\
\text { cent) }\end{array}$ & $\begin{array}{l}0.062 \\
\text { um } \\
\text { (per- } \\
\text { cent) }\end{array}$ \\
\hline & \multicolumn{2}{|c|}{07103780} & MONUMENT & CREEK ABOV & E NORTH & GATE BOUL & VARD A & U.S. AI & R FORCE & ACADEMY & (SITE M5) & & \\
\hline $\begin{array}{l}104-18-85 \\
1_{05}-03-85 \\
2_{08}-12-85 \\
2_{10-29-85} \\
204-14-86\end{array}$ & $\begin{array}{c}-- \\
-- \\
-- \\
100\end{array}$ & $\begin{array}{r}-- \\
-- \\
100 \\
100 \\
50\end{array}$ & $\begin{array}{c}100 \\
-- \\
70 \\
59 \\
32\end{array}$ & $\begin{array}{r}96 \\
100 \\
37 \\
41 \\
13\end{array}$ & $\begin{array}{r}88 \\
96 \\
27 \\
26 \\
8\end{array}$ & $\begin{array}{r}59 \\
81 \\
24 \\
17 \\
5\end{array}$ & $\begin{array}{r}39 \\
63 \\
22 \\
14 \\
3\end{array}$ & $\begin{array}{r}21 \\
42 \\
16 \\
11 \\
2\end{array}$ & $\begin{array}{r}10 \\
26 \\
10 \\
7 \\
1\end{array}$ & $\begin{array}{r}4 \\
16 \\
4 \\
3 \\
0\end{array}$ & $\begin{array}{l}1 \\
6 \\
1 \\
1 \\
0\end{array}$ & $\begin{array}{l}0 \\
1 \\
0 \\
0 \\
0\end{array}$ & $\begin{array}{l}0 \\
0 \\
0 \\
0 \\
0\end{array}$ \\
\hline $\begin{array}{l}207-10-86 \\
208-25-86 \\
211-05-86 \\
204-27-87 \\
1_{0} 04-30-87\end{array}$ & $\begin{array}{r}-- \\
100 \\
-- \\
-- \\
--\end{array}$ & $\begin{array}{r}100 \\
85 \\
100 \\
100 \\
100\end{array}$ & $\begin{array}{l}40 \\
72 \\
68 \\
83 \\
62\end{array}$ & $\begin{array}{l}21 \\
28 \\
27 \\
16 \\
28\end{array}$ & $\begin{array}{r}14 \\
17 \\
18 \\
6 \\
11\end{array}$ & $\begin{array}{r}8 \\
10 \\
15 \\
3 \\
6\end{array}$ & $\begin{array}{r}5 \\
6 \\
10 \\
1 \\
3\end{array}$ & $\begin{array}{l}2 \\
3 \\
8 \\
1 \\
2\end{array}$ & $\begin{array}{l}1 \\
2 \\
6 \\
0 \\
1\end{array}$ & $\begin{array}{l}0 \\
1 \\
4 \\
0 \\
0\end{array}$ & $\begin{array}{l}0 \\
0 \\
1 \\
0 \\
0\end{array}$ & $\begin{array}{l}0 \\
0 \\
0 \\
0 \\
0\end{array}$ & $\begin{array}{l}0 \\
0 \\
0 \\
0 \\
0\end{array}$ \\
\hline $\begin{array}{l}207-14-87 \\
208-26-87 \\
211-03-87 \\
204-25-88 \\
206-30-88\end{array}$ & $\begin{array}{r}100 \\
\ldots \\
100 \\
100 \\
100\end{array}$ & $\begin{array}{r}65 \\
100 \\
75 \\
56 \\
84\end{array}$ & $\begin{array}{l}38 \\
54 \\
28 \\
28 \\
37\end{array}$ & $\begin{array}{r}19 \\
19 \\
7 \\
18 \\
23\end{array}$ & $\begin{array}{r}11 \\
10 \\
3 \\
10 \\
11\end{array}$ & $\begin{array}{l}8 \\
6 \\
1 \\
6 \\
6\end{array}$ & $\begin{array}{l}6 \\
4 \\
0 \\
4 \\
3\end{array}$ & $\begin{array}{l}4 \\
2 \\
0 \\
2 \\
2\end{array}$ & $\begin{array}{l}2 \\
1 \\
0 \\
1 \\
1\end{array}$ & $\begin{array}{l}1 \\
0 \\
0 \\
0 \\
0\end{array}$ & $\begin{array}{l}0 \\
0 \\
0 \\
0 \\
0\end{array}$ & $\begin{array}{l}0 \\
0 \\
0 \\
0 \\
0\end{array}$ & $\begin{array}{l}0 \\
0 \\
0 \\
0 \\
0\end{array}$ \\
\hline \multirow[t]{2}{*}{${ }^{2} 09-07-88$} & 100 & 72 & 60 & 18 & 7 & 4 & 2 & 1 & 0 & 0 & 0 & 0 & 0 \\
\hline & \multicolumn{13}{|c|}{07104000} \\
\hline $\begin{array}{l}104-03-85 \\
1_{05}-02-85 \\
2_{0} 08-12-85 \\
1_{10-28-85} \\
{ }^{2} 04-14-86\end{array}$ & $\begin{array}{l}-- \\
-- \\
-- \\
-- \\
--\end{array}$ & $\begin{array}{l}-- \\
-- \\
-- \\
--\end{array}$ & $\begin{array}{r}-- \\
100 \\
-- \\
--\end{array}$ & $\begin{array}{r}100 \\
98 \\
100 \\
100 \\
100\end{array}$ & $\begin{array}{r}99 \\
98 \\
100 \\
100 \\
98\end{array}$ & $\begin{array}{l}92 \\
96 \\
94 \\
98 \\
94\end{array}$ & $\begin{array}{l}80 \\
80 \\
81 \\
90 \\
81\end{array}$ & $\begin{array}{l}57 \\
48 \\
56 \\
68 \\
58\end{array}$ & $\begin{array}{l}32 \\
21 \\
30 \\
38 \\
33\end{array}$ & $\begin{array}{r}14 \\
9 \\
15 \\
16 \\
16\end{array}$ & $\begin{array}{l}3 \\
2 \\
4 \\
3 \\
3\end{array}$ & $\begin{array}{l}0 \\
0 \\
1 \\
0 \\
0\end{array}$ & $\begin{array}{l}0 \\
0 \\
0 \\
0 \\
0\end{array}$ \\
\hline $\begin{array}{l}207-10-86 \\
208-25-86 \\
211-05-86 \\
204-27-87 \\
104-29-87\end{array}$ & $\begin{array}{l}-- \\
-- \\
-- \\
--\end{array}$ & $\begin{array}{l}-- \\
-- \\
-- \\
--\end{array}$ & $\begin{array}{r}100 \\
100 \\
-- \\
-- \\
--\end{array}$ & $\begin{array}{r}98 \\
98 \\
100 \\
100 \\
100\end{array}$ & $\begin{array}{l}93 \\
97 \\
99 \\
99 \\
98\end{array}$ & $\begin{array}{l}88 \\
94 \\
94 \\
92 \\
90\end{array}$ & $\begin{array}{l}77 \\
85 \\
82 \\
75 \\
71\end{array}$ & $\begin{array}{l}55 \\
67 \\
60 \\
48 \\
44\end{array}$ & $\begin{array}{l}33 \\
42 \\
34 \\
25 \\
21\end{array}$ & $\begin{array}{r}15 \\
22 \\
17 \\
10 \\
8\end{array}$ & $\begin{array}{l}5 \\
6 \\
5 \\
2 \\
1\end{array}$ & $\begin{array}{l}1 \\
1 \\
1 \\
0 \\
0\end{array}$ & $\begin{array}{l}0 \\
0 \\
0 \\
0 \\
0\end{array}$ \\
\hline \multirow[t]{2}{*}{$\begin{array}{l}207-14-87 \\
208-26-87 \\
211-04-87 \\
204-25-88 \\
206-30-88 \\
209-07-88\end{array}$} & $\begin{array}{l}-- \\
-- \\
-- \\
-- \\
--\end{array}$ & $\begin{array}{l}-- \\
-- \\
-- \\
-- \\
--\end{array}$ & $\begin{array}{l}-- \\
-- \\
-- \\
-- \\
--\end{array}$ & $\begin{array}{l}100 \\
100 \\
100 \\
100 \\
100 \\
100\end{array}$ & $\begin{array}{l}98 \\
98 \\
99 \\
99 \\
98 \\
99\end{array}$ & $\begin{array}{l}91 \\
94 \\
97 \\
93 \\
90 \\
95\end{array}$ & $\begin{array}{l}73 \\
80 \\
88 \\
76 \\
74 \\
83\end{array}$ & $\begin{array}{l}44 \\
52 \\
60 \\
50 \\
50 \\
58\end{array}$ & $\begin{array}{l}22 \\
28 \\
33 \\
27 \\
28 \\
34\end{array}$ & $\begin{array}{r}9 \\
14 \\
15 \\
11 \\
15 \\
16\end{array}$ & $\begin{array}{l}2 \\
4 \\
4 \\
2 \\
5 \\
5\end{array}$ & $\begin{array}{l}0 \\
1 \\
1 \\
0 \\
1 \\
0\end{array}$ & $\begin{array}{l}0 \\
0 \\
0 \\
0 \\
0 \\
0\end{array}$ \\
\hline & & 071 & 104905 & ONUMENT CF & EEK AT B & BIJOU STRE & I AT C & LORADO S & PRINGS & (SITE M16 & & & \\
\hline $\begin{array}{l}1_{04-03-85} \\
1_{05-02-85} \\
1_{04-30-87}\end{array}$ & $\begin{array}{l}-- \\
-- \\
--\end{array}$ & $\begin{array}{l}-- \\
--\end{array}$ & $\begin{array}{c}-- \\
--\end{array}$ & $\begin{array}{r}100 \\
97 \\
100\end{array}$ & $\begin{array}{l}93 \\
93 \\
99\end{array}$ & $\begin{array}{l}82 \\
85 \\
94\end{array}$ & $\begin{array}{l}68 \\
72 \\
83\end{array}$ & $\begin{array}{l}48 \\
51 \\
62\end{array}$ & $\begin{array}{l}27 \\
27 \\
38\end{array}$ & $\begin{array}{l}11 \\
11 \\
18\end{array}$ & $\begin{array}{l}2 \\
2 \\
2\end{array}$ & $\begin{array}{l}1 \\
0 \\
0\end{array}$ & $\begin{array}{l}0 \\
0 \\
0\end{array}$ \\
\hline
\end{tabular}

${ }^{1}$ Samples collected in conjunction with bedload measurement.

${ }^{2}$ Samples collected in conjunction with benthic-invertebrate samples.

${ }^{3}$ Sample collected was not in conjunction with bedload measurement or benthic-invertebrate samples. Sample was collected with the 6-in. diameter scoop near the bedload measurement section.

'Sample was collected in conjunction with a bedload sample; however, the bedload sample was not used in any analysis due to problems with bedload sampling. 
Table 17.--Bedload size distribution for selected sites on Fountain and Monument Creeks, water years 1985-88 [mm, millimeters; --, not applicable]

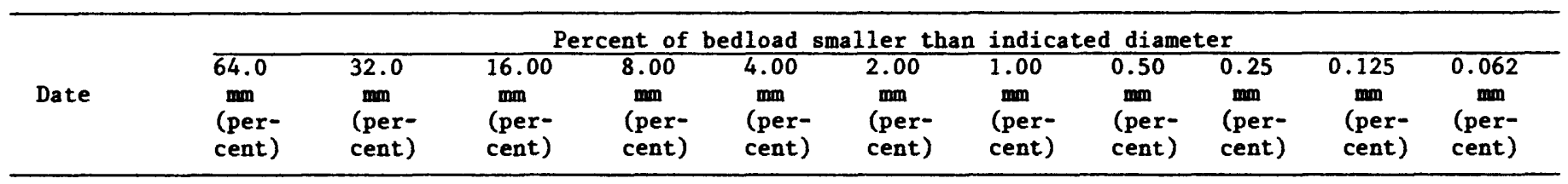

\section{FOUNTAIN CREEK NEAR COLORADO SPRINGS (SITE F4)}

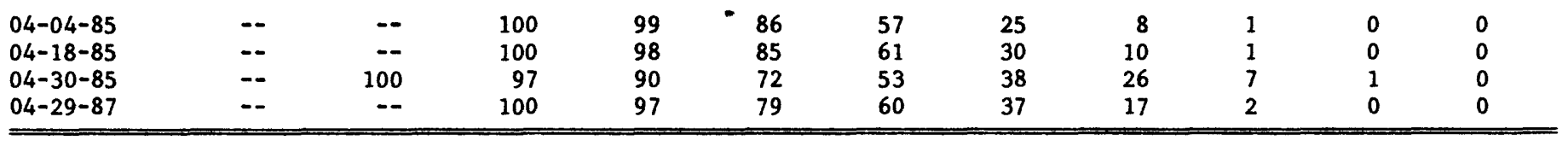

\section{FOUNTAIN CREEK AT COLORADO SPRINGS (SITE F8)}

\begin{tabular}{|c|c|c|c|c|c|c|c|c|c|c|c|}
\hline $04-04-85$ & -- & - & 100 & 94 & 82 & 58 & 36 & 18 & 3 & 0 & 0 \\
\hline $05-02-85$ & - & - & 100 & 91 & 75 & 54 & 29 & 12 & 4 & 1 & 0 \\
\hline $05-03-85$ & $-\infty$ & - & 100 & 98 & 78 & 45 & 26 & 17 & 6 & 1 & 0 \\
\hline $05-01-87$ & - & - & 100 & 96 & 86 & 64 & 35 & 15 & 3 & 0 & 0 \\
\hline $06-24-88$ & -- & 100 & 99 & 95 & 84 & 63 & 41 & 25 & 6 & 1 & 0 \\
\hline $06-24-88$ & - & 100 & 99 & 94 & 83 & 64 & 42 & 22 & 5 & 1 & 0 \\
\hline
\end{tabular}

\section{FOUNTAIN CREEK AT SECURITY (SITE F13)}

\begin{tabular}{|c|c|c|c|c|c|c|c|c|c|c|c|}
\hline $\begin{array}{l}04-04-85 \\
05-03-85 \\
10-28-85 \\
05-01-87 \\
08-26-87 \\
06-15-88 \\
08-09-88\end{array}$ & $\begin{array}{l}-- \\
-- \\
-- \\
-- \\
-- \\
-- \\
100\end{array}$ & $\begin{array}{c}-- \\
100 \\
-- \\
100 \\
100 \\
-- \\
99\end{array}$ & $\begin{array}{r}100 \\
98 \\
100 \\
99 \\
97 \\
100 \\
94\end{array}$ & $\begin{array}{l}94 \\
94 \\
96 \\
95 \\
89 \\
96 \\
87\end{array}$ & $\begin{array}{l}80 \\
86 \\
84 \\
85 \\
75 \\
87 \\
72\end{array}$ & $\begin{array}{l}58 \\
71 \\
59 \\
64 \\
55 \\
63 \\
47\end{array}$ & $\begin{array}{l}30 \\
52 \\
32 \\
40 \\
36 \\
36 \\
19\end{array}$ & $\begin{array}{r}12 \\
34 \\
13 \\
19 \\
20 \\
21 \\
6\end{array}$ & $\begin{array}{l}2 \\
9 \\
1 \\
2 \\
4 \\
5 \\
1\end{array}$ & $\begin{array}{l}0 \\
1 \\
0 \\
0 \\
1 \\
0 \\
0\end{array}$ & $\begin{array}{l}0 \\
0 \\
0 \\
0 \\
0 \\
0 \\
0\end{array}$ \\
\hline
\end{tabular}

07103780 MONUMENT CREEK ABOVE NORTH GATE BOULEVARD AT U.S. AIR FORCE ACADEMY (SITE M5)

\begin{tabular}{|c|c|c|c|c|c|c|c|c|c|c|c|}
\hline $\begin{array}{l}04-18-85 \\
05-03-85 \\
04-30-87\end{array}$ & $\begin{array}{l}-- \\
--\end{array}$ & $\begin{array}{l}100 \\
100 \\
100\end{array}$ & $\begin{array}{l}95 \\
95 \\
98\end{array}$ & $\begin{array}{l}78 \\
81 \\
95\end{array}$ & $\begin{array}{l}60 \\
58 \\
86\end{array}$ & $\begin{array}{l}39 \\
34 \\
67\end{array}$ & $\begin{array}{l}22 \\
17 \\
45\end{array}$ & $\begin{array}{r}12 \\
9 \\
21\end{array}$ & $\begin{array}{l}2 \\
2 \\
3\end{array}$ & $\begin{array}{l}0 \\
0 \\
0\end{array}$ & $\begin{array}{l}0 \\
0 \\
0\end{array}$ \\
\hline
\end{tabular}

\section{MONUMENT CREEK AT PIKEVIEW (SITE M10)}

\begin{tabular}{|c|c|c|c|c|c|c|c|c|c|c|c|}
\hline $\begin{array}{l}04-03-85 \\
05-02-85 \\
04-29-87\end{array}$ & $\begin{array}{l}-- \\
--\end{array}$ & $\begin{array}{r}-- \\
100 \\
100\end{array}$ & $\begin{array}{r}100 \\
92 \\
99\end{array}$ & $\begin{array}{l}98 \\
87 \\
94\end{array}$ & $\begin{array}{l}92 \\
74 \\
91\end{array}$ & $\begin{array}{l}74 \\
53 \\
67\end{array}$ & $\begin{array}{l}49 \\
35 \\
37\end{array}$ & $\begin{array}{l}29 \\
23 \\
16\end{array}$ & $\begin{array}{l}8 \\
8 \\
3\end{array}$ & $\begin{array}{l}1 \\
1 \\
0\end{array}$ & $\begin{array}{l}0 \\
0 \\
0\end{array}$ \\
\hline
\end{tabular}

07104905 MONUMENT CREEK AT BIJOU STREET AT COLORADO SPRINGS (SITE M16)

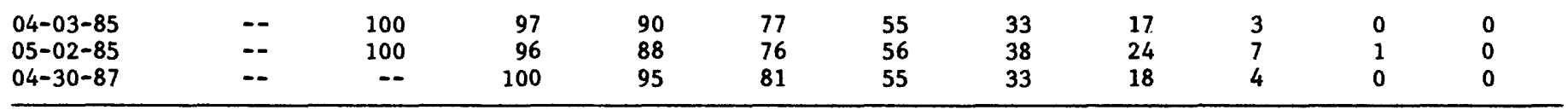




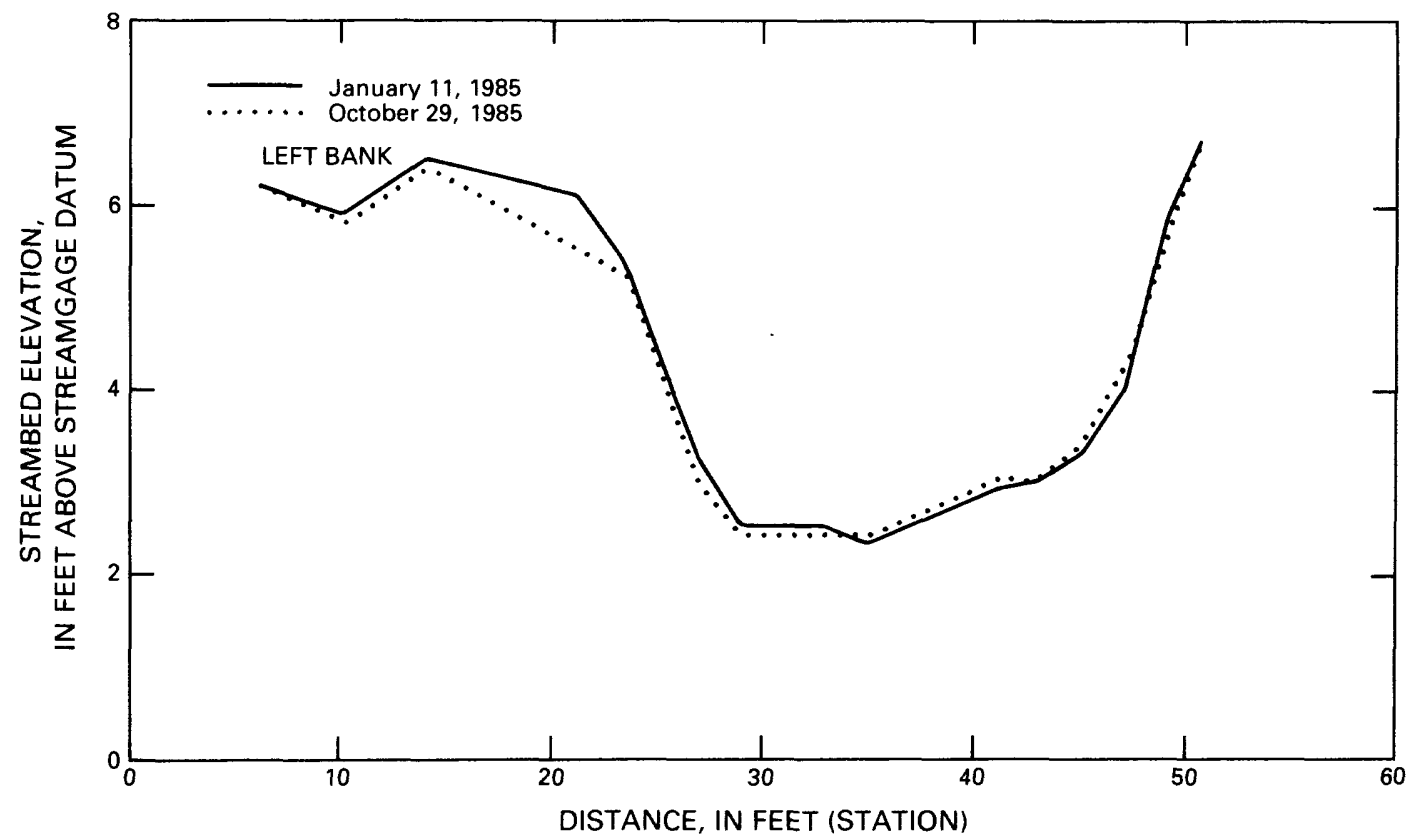

Figure 16.--Selected stream-channel cross-section surveys for Fountain Creek near Colorado Springs (site F4).

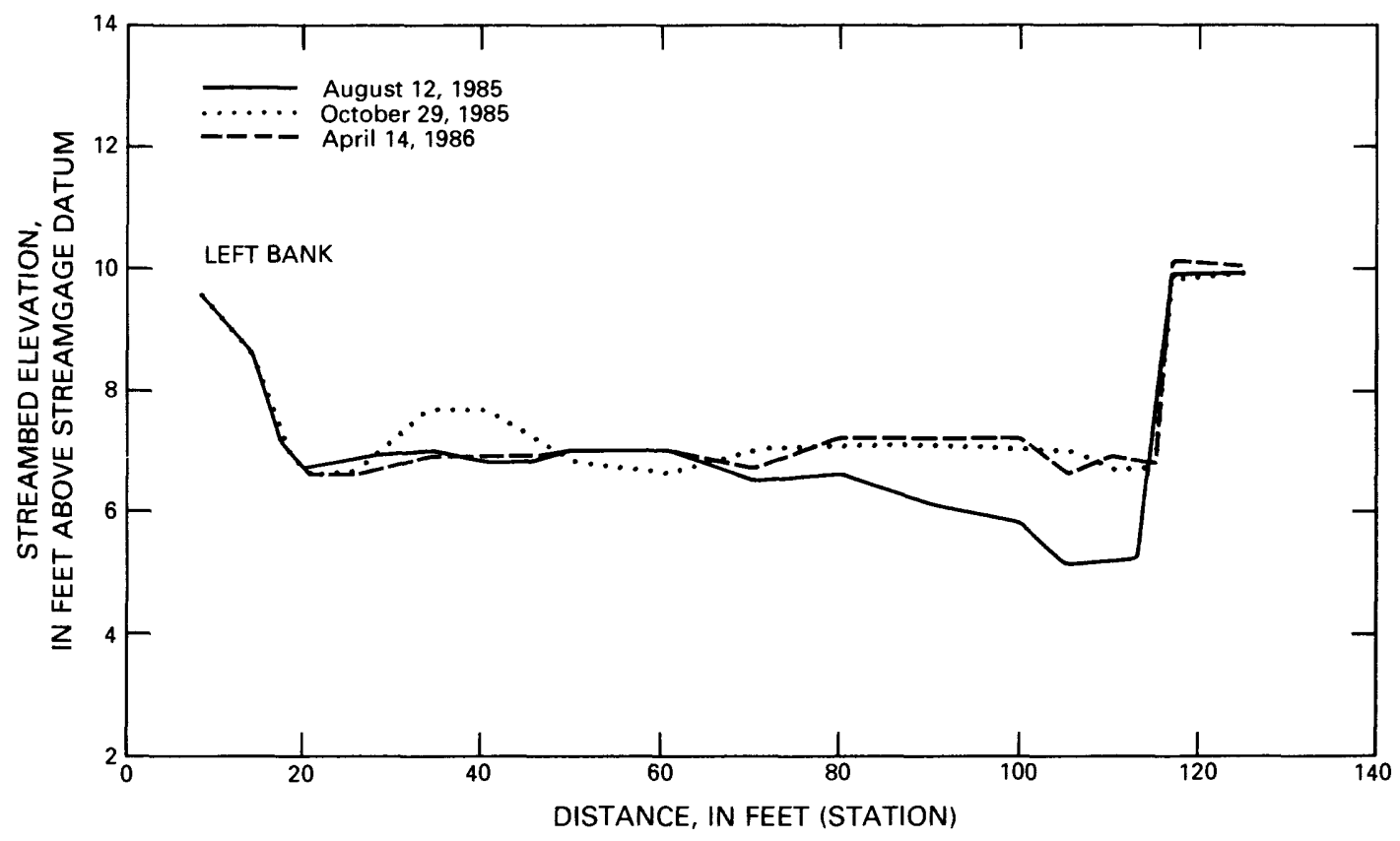

Figure 17.--Selected stream-channel cross-section surveys upstream from streamflow-gaging station Fountain Creek at Colorado Springs (site F8). 


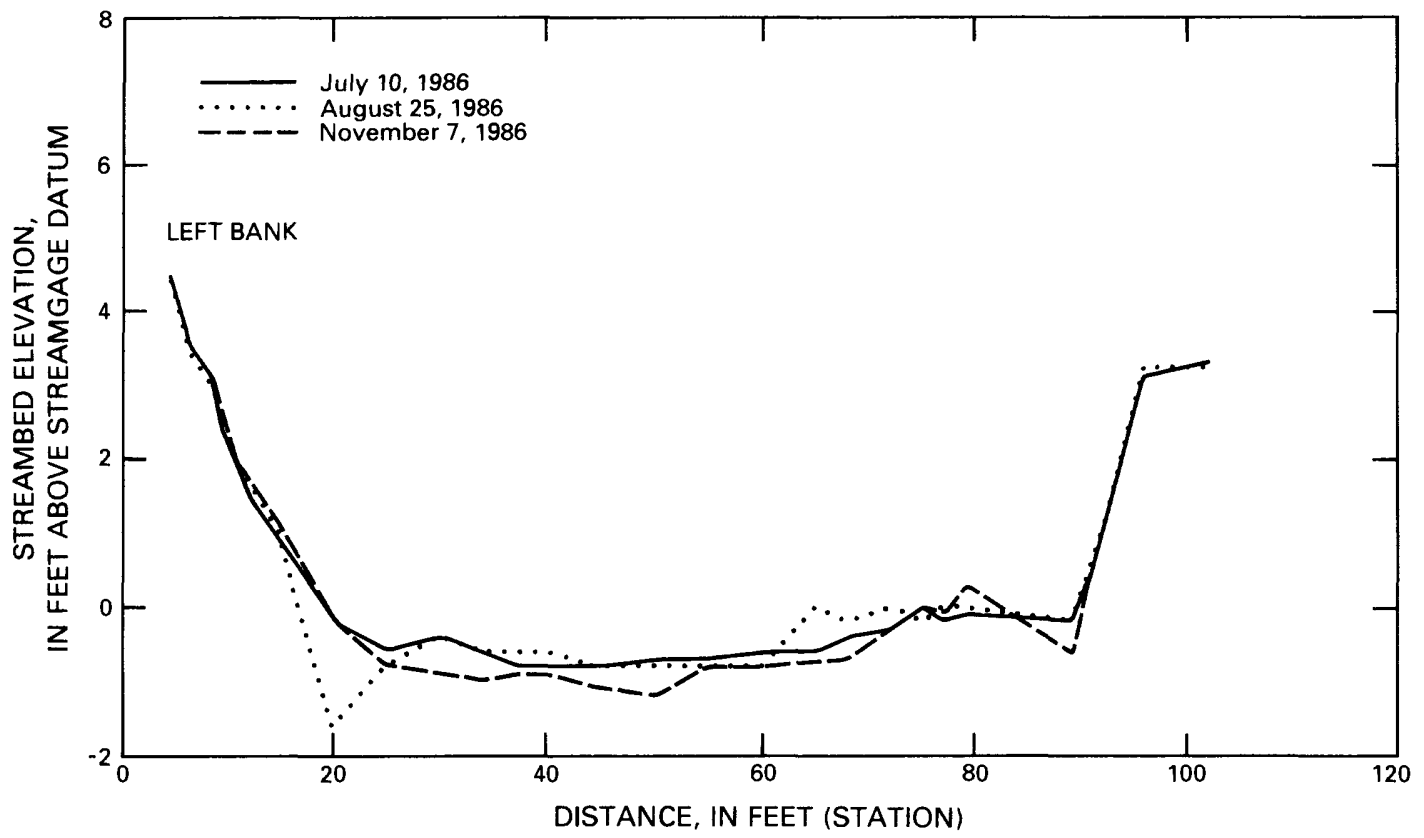

Figure 18.--Selected stream-channel cross-section surveys downstream from streamflow-gaging station Fountain Creek at Colorado Springs (site F8).

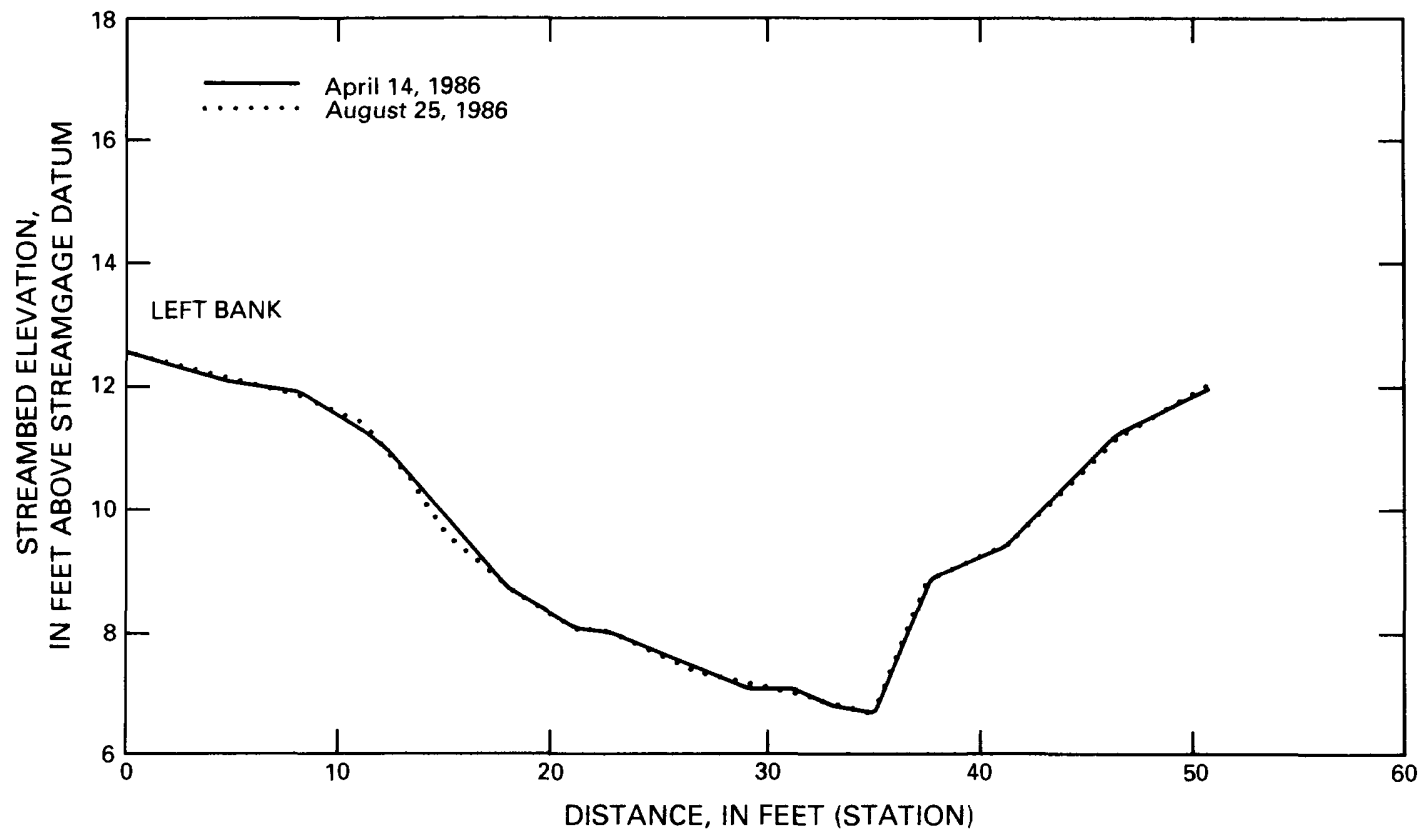

Figure 19.--Selected stream-channel cross-section surveys for Monument Creek above North Gate Boulevard at U.S. Air Force Academy (site M5). 


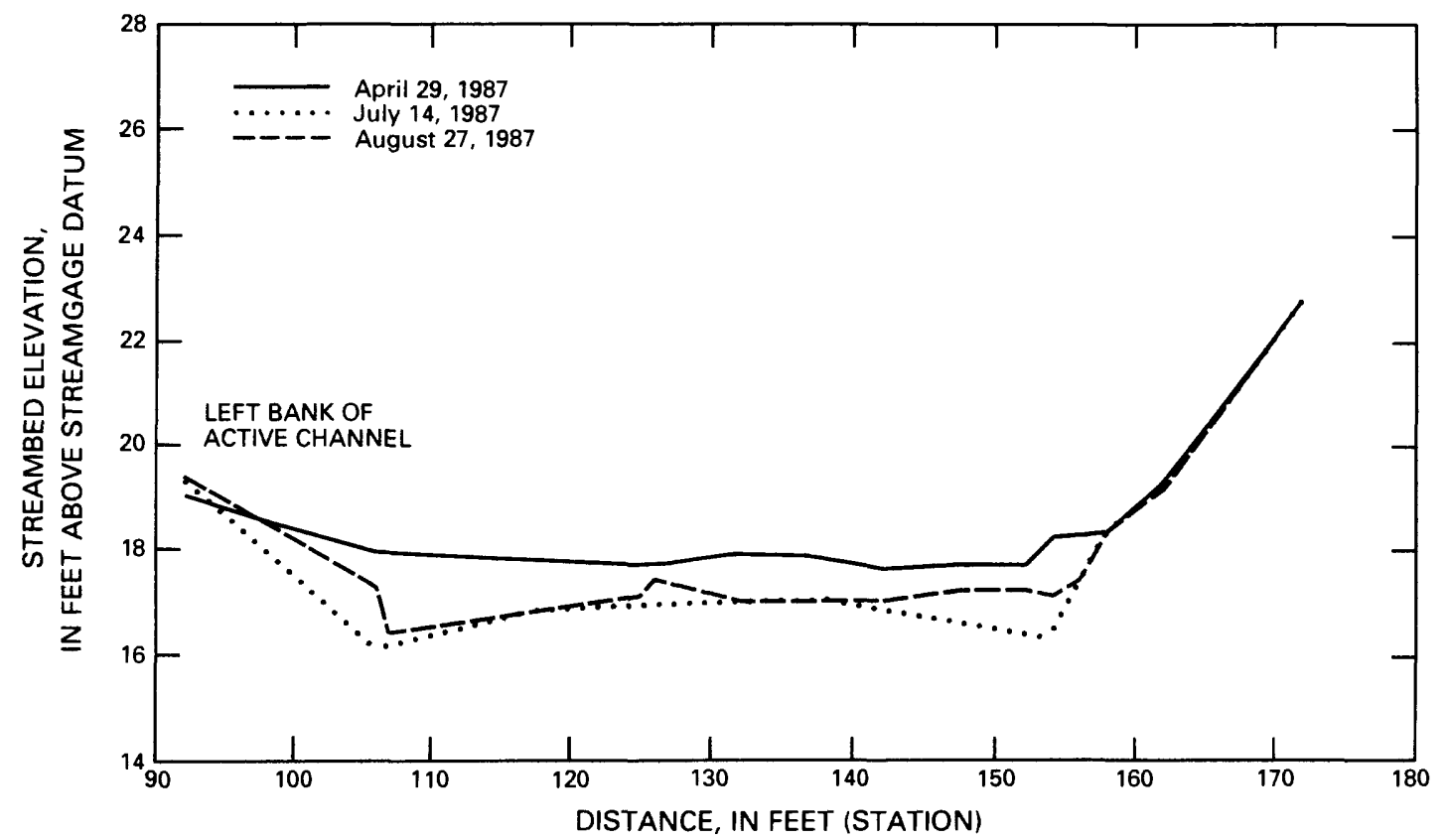

Figure 20.--Selected stream-channel cross-section surveys for Monument Creek at Pikeview (site M10). (Cross sections depicted are for stations 92.0 through $172.0 \mathrm{ft}$. The entire cross section is about $172.0 \mathrm{ft}$ wide; however, the active stream channel having perennial streamflow is $80.0 \mathrm{ft}$ wide.) 
Table 18.--Summary of stream-channel cross-section data for selected sites on Fountain and Nonument Creeks, water years 1985-88

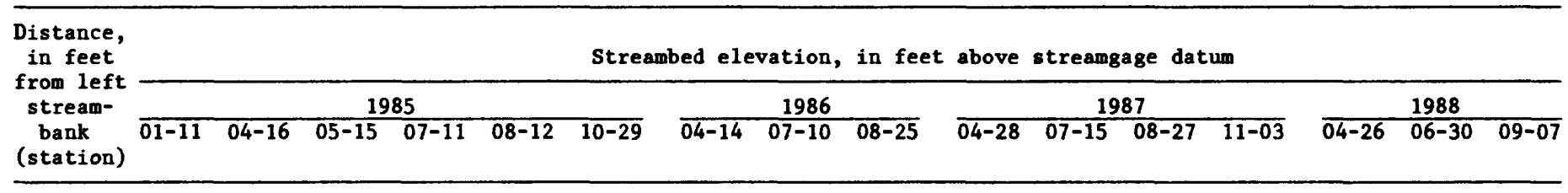

\section{FOUNTAIN CREEK NEAR COLORADO SPRINGS (SITE F4)}

\begin{tabular}{|c|c|c|c|c|c|c|c|c|c|c|c|c|c|c|c|c|}
\hline $\begin{array}{r}5.0 \\
6.0 \\
10.0 \\
14.0\end{array}$ & $\begin{array}{l}-- \\
6.2 \\
5.9 \\
6.5\end{array}$ & $\begin{array}{l}-- \\
6.3 \\
5.8 \\
6.4\end{array}$ & $\begin{array}{l}-- \\
6.3 \\
5.8 \\
6.4\end{array}$ & $\begin{array}{l}-- \\
6.3 \\
5.8 \\
6.4\end{array}$ & $\begin{array}{l}-- \\
6.3 \\
5.8 \\
6.4\end{array}$ & $\begin{array}{l}-- \\
6.2 \\
5.8 \\
6.4\end{array}$ & $\begin{array}{l}-- \\
6.3 \\
5.8 \\
6.4\end{array}$ & $\begin{array}{r}-- \\
6.3 \\
5.8 \\
-.-\end{array}$ & $\begin{array}{r}-- \\
6.4 \\
5.8 \\
--\end{array}$ & $\begin{array}{r}-- \\
6.4 \\
5.8 \\
--\end{array}$ & $\begin{array}{r}-- \\
6.4 \\
5.8 \\
--\end{array}$ & $\begin{array}{r}-- \\
6.3 \\
5.8 \\
--\end{array}$ & $\begin{array}{r}-- \\
6.3 \\
5.8 \\
-.\end{array}$ & $\begin{array}{r}-- \\
6.4 \\
5.8 \\
--\end{array}$ & $\begin{array}{r}6.4 \\
-- \\
5.8 \\
6.7\end{array}$ & $\begin{array}{l}-- \\
5.5 \\
5.8 \\
6.7\end{array}$ \\
\hline 20.0 & -- & -- & -- & -- & -- & -- & -- & -- & -- & -- & -- & -- & -- & -- & 6.4 & - \\
\hline $\begin{array}{l}21.0 \\
23.5\end{array}$ & $\begin{array}{l}6.1 \\
5.3\end{array}$ & $\begin{array}{l}6.1 \\
5.2\end{array}$ & $\begin{array}{l}6.1 \\
5.2\end{array}$ & $\begin{array}{l}6.1 \\
5.3\end{array}$ & $\begin{array}{l}6.0 \\
5.2\end{array}$ & $5 . \overline{2}$ & $5 . \overline{3}$ & $5 . \overline{3}$ & $5 . \overline{4}$ & $5 . \overline{4}$ & 5.4 & $5 . \overline{4}$ & $5 . \overline{5}$ & $5 . \overline{4}$ & $=$ & $5 . \overline{6}$ \\
\hline 24.0 & -- & -- & -- & -- & -- & -- & -- & -- & -- & -- & -- & -- & -- & -- & 5.4 & -- \\
\hline 26.0 & -- & -- & -- & -- & -- & -- & -- & -- & -- & -- & -- & -- & -- & -- & 3.8 & -- \\
\hline 26.5 & -- & -- & -- & -- & -- & -- & -- & -- & -- & -- & -- & -- & -- & -- & 3.2 & -- \\
\hline 27.0 & 3.2 & 3.2 & 2.9 & 2.9 & 2.9 & 3.0 & 3.1 & 3.2 & 3.0 & 3.0 & 3.0 & 3.1 & 2.9 & 3.1 & -- & 3.6 \\
\hline 29.0 & 2.5 & 2.8 & 2.6 & 2.6 & 2.5 & 2.4 & 2.4 & 2.8 & 2.5 & 2.7 & 2.9 & 2.8 & 2.7 & 2.7 & 3.1 & 3.0 \\
\hline 30.0 & -- & -- & -- & -- & -- & -- & -- & -- & -- & -- & -- & -- & -- & -- & 2.7 & 2.9 \\
\hline 31.0 & 2.5 & 2.4 & 2.7 & 2.6 & 2.3 & 2.4 & 2.3 & 2.7 & 2.4 & 2.4 & 2.7 & 2.6 & 2.6 & 2.6 & -- & 2.7 \\
\hline 33.0 & 2.5 & 2.4 & 2.5 & 2.4 & 2.4 & 2.4 & 2.5 & 2.6 & 2.4 & 2.4 & 2.4 & 2.4 & 2.4 & 2.4 & 2.4 & 2.4 \\
\hline 35.0 & 2.3 & 2.4 & 2.3 & 2.3 & 2.3 & 2.4 & 2.5 & 2.5 & 2.4 & 2.5 & 2.3 & 2.4 & 2.5 & 2.6 & -- & 2.5 \\
\hline 36.0 & -- & -- & -- & -- & -- & -- & -- & -- & -- & -- & -- & -- & -- & -- & 2.4 & -- \\
\hline 37.0 & 2.5 & 2.5 & 2.5 & 2.5 & 2.5 & 2.6 & 2.5 & 2.6 & 2.6 & 2.5 & 2.0 & 2.6 & 2.5 & 2.5 & -- & 2.6 \\
\hline 39.0 & 2.7 & 2.7 & 2.7 & 2.7 & 2.6 & 2.8 & 2.7 & 2.9 & 2.6 & 2.6 & 2.4 & 2.5 & 2.4 & 2.4 & 2.7 & 2.5 \\
\hline 41.0 & 2.9 & 2.9 & 2.9 & 2.9 & 2.8 & 3.0 & 2.9 & 2.9 & 2.9 & 2.9 & 2.8 & 2.9 & 2.7 & 2.8 & -- & 2.7 \\
\hline 43.0 & 3.0 & 3.0 & 3.1 & 3.0 & 3.0 & 3.0 & 3.0 & 3.2 & 3.0 & 3.0 & 2.8 & 2.9 & 2.8 & 2.8 & 2.8 & 2.7 \\
\hline 45.0 & 3.3 & 3.1 & 3.2 & 3.2 & 3.2 & 3.4 & 3.3 & 3.1 & 3.1 & 3.2 & 3.1 & 3.1 & 2.9 & 3.1 & -- & 3.3 \\
\hline 45.5 & -- & -- & -- & -- & -- & -- & -- & -- & -- & -- & -- & -- & -- & -- & 3.0 & -- \\
\hline 47.0 & 4.0 & 3.9 & 3.9 & 3.9 & 3.9 & 4.2 & 4.0 & 3.9 & 4.0 & 4.0 & 4.0 & 4.0 & 3.8 & 3.8 & -- & 4.1 \\
\hline 48.0 & -- & -- & -- & -- & -- & -- & -- & -- & -- & -- & -- & -- & -- & -- & 4.5 & -- \\
\hline $\begin{array}{l}49.0 \\
50.7\end{array}$ & $\begin{array}{l}5.8 \\
6.7\end{array}$ & $\begin{array}{l}5.6 \\
6.4\end{array}$ & $\begin{array}{l}5.7 \\
6.7\end{array}$ & $\begin{array}{l}5.7 \\
6.6\end{array}$ & $\begin{array}{l}5.6 \\
6.6\end{array}$ & $\begin{array}{l}5.6 \\
6.6\end{array}$ & $\begin{array}{l}5.8 \\
6.6\end{array}$ & $\begin{array}{l}5.7 \\
6.6\end{array}$ & $\begin{array}{l}5.8 \\
6.6\end{array}$ & $\begin{array}{l}5.8 \\
6.7\end{array}$ & $\begin{array}{l}5.5 \\
6.6\end{array}$ & $\begin{array}{l}5.8 \\
6.6\end{array}$ & $\begin{array}{l}5.7 \\
6.6\end{array}$ & $\begin{array}{l}5.7 \\
6.7\end{array}$ & -- & $\begin{array}{l}5.8 \\
6.6\end{array}$ \\
\hline 50.8 & -- & -- & -- & -- & -- & -- & -- & -- & -- & -- & $=$ & $=-$ & -- & -- & 6.6 & - \\
\hline
\end{tabular}


Table 18.--summary of stream-channel cross-section data for selected sites on Fountain and Monument Creeks, water years 1985-88--Continued

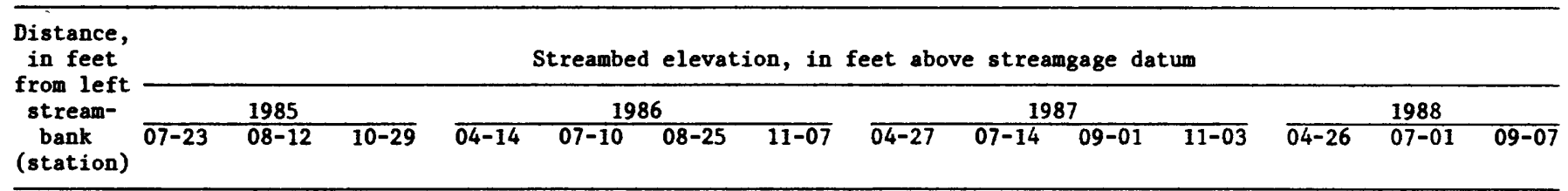

07105500 FOUNTAIN CREEK AT COLORADO SPRINGS (UPSTREAM FROM NEVADA STREET, SITE F8)

\begin{tabular}{|c|c|c|c|c|c|c|c|c|c|c|c|c|c|c|}
\hline $\begin{array}{l}0.0 \\
8.0\end{array}$ & $9 . \overline{1}$ & $9 . \overline{-}$ & 9.6 & $9 . \overline{-}$ & 9.6 & $9 . \overline{9}$ & 9.6 & 9.6 & 9.6 & 9.7 & 9.6 & $9 . \overline{7}$ & $\begin{array}{r}9.6 \\
-2\end{array}$ & $\begin{array}{r}10.0 \\
9.6\end{array}$ \\
\hline 10.0 & - & - & - & -- & - & - & -- & -- & -- & -- & -- & -- & 9.4 & -- \\
\hline 14.0 & 8.4 & 8.6 & 8.6 & 8.6 & 8.6 & 8.6 & 8.7 & 8.6 & 8.8 & 8.9 & 8.8 & 8.9 & -- & 9.0 \\
\hline 16.0 & -- & -- & -- & -- & -- & -- & -- & -- & -- & -- & -- & -- & 8.3 & -- \\
\hline $\begin{array}{l}17.0 \\
20.0\end{array}$ & $\begin{array}{l}7.1 \\
6.2\end{array}$ & $\begin{array}{l}7.2 \\
6.7\end{array}$ & $\begin{array}{l}7.4 \\
6.6\end{array}$ & $\begin{array}{l}7.3 \\
6.6\end{array}$ & $\begin{array}{l}7.8 \\
7.0\end{array}$ & $\begin{array}{l}7.9 \\
7.0\end{array}$ & $\begin{array}{l}7.8 \\
6.6\end{array}$ & $\begin{array}{l}7.9 \\
6.6\end{array}$ & $\begin{array}{l}8.1 \\
6.5\end{array}$ & $\begin{array}{l}8.1 \\
6.7\end{array}$ & $\begin{array}{l}8.0 \\
6.5\end{array}$ & $\begin{array}{l}8.0 \\
6.9\end{array}$ & $6 . \overline{8}$ & $\begin{array}{l}8.2 \\
7.2\end{array}$ \\
\hline 22.0 & - & - & - & -- & -- & $=$ & -- & -- & -- & -- & - & - & 6.4 & 6.6 \\
\hline 25.0 & -- & -- & -- & -- & -- & -- & -- & -- & -- & -- & -- & -- & 6.4 & -- \\
\hline 26.0 & 6.3 & 6.9 & 6.7 & 6.6 & 7.0 & 6.9 & 6.5 & 6.5 & 6.3 & 6.5 & 6.4 & 6.8 & -- & 6.4 \\
\hline 30.0 & -- & -- & -- & -- & -- & -- & -- & -- & -- & -- & -- & -- & 6.5 & -- \\
\hline 31.0 & -- & -- & -- & -- & -- & -- & -- & -- & -- & -- & -- & -- & -- & 6.6 \\
\hline 34.0 & 6.6 & 7.0 & 7.7 & 6.9 & 6.8 & 6.6 & 6.6 & 6.6 & 6.3 & 6.4 & 6.4 & 6.5 & -- & 6.8 \\
\hline 35.0 & -- & -- & -- & -- & -- & -- & -- & - & - & -- & -- & -- & 6.5 & -- \\
\hline 40.0 & 6.8 & 6.8 & 7.7 & 6.9 & 6.6 & 6.6 & 6.7 & 6.5 & 6.4 & 6.3 & 6.3 & 6.4 & 6.7 & 6.6 \\
\hline $\begin{array}{l}45.0 \\
50.0\end{array}$ & $\begin{array}{l}7.1 \\
7.1\end{array}$ & $\begin{array}{l}6.8 \\
7.0\end{array}$ & $\begin{array}{l}7.3 \\
6.8\end{array}$ & $\begin{array}{l}6.9 \\
7.0\end{array}$ & $\begin{array}{l}6.6 \\
6.6\end{array}$ & $\begin{array}{l}6.7 \\
6.9\end{array}$ & $\begin{array}{l}6.9 \\
6.9\end{array}$ & $\begin{array}{l}6.5 \\
6.5\end{array}$ & $\begin{array}{l}6.4 \\
6.3\end{array}$ & $\begin{array}{l}6.1 \\
6.2\end{array}$ & $\begin{array}{l}6.3 \\
6.3\end{array}$ & $\begin{array}{l}6.3 \\
6.4\end{array}$ & $\begin{array}{l}6.6 \\
6.5\end{array}$ & $\begin{array}{l}6.2 \\
6.2\end{array}$ \\
\hline 55.0 & -- & - & - & -- & -- & -- & -- & -- & -- & -- & - & -- & 6.6 & - \\
\hline 60.0 & 6.7 & 7.0 & 6.6 & 7.0 & 7.2 & 6.7 & 6.6 & 6.6 & 6.2 & 6.2 & 6.3 & 6.4 & 6.3 & 6.6 \\
\hline 65.0 & -- & -- & $=$ & -- & -- & -- & -- & -- & -- & -- & -- & -- & 6.4 & -- \\
\hline 70.0 & 6.9 & 6.5 & 7.0 & 6.7 & 6.4 & 6.6 & 6.5 & 6.5 & 6.3 & 6.7 & 6.5 & 6.7 & 6.4 & 6.8 \\
\hline 72.0 & -- & -- & -- & -- & -- & -- & -- & -- & -- & -- & -- & -- & -- & 6.8 \\
\hline 75.0 & -- & -- & - & -- & -- & -- & -- & -- & -- & -- & -- & -- & 6.6 & -- \\
\hline 76.0 & -- & -- & -- & -- & -- & -- & -- & -- & -- & -- & -- & - & 6.8 & -- \\
\hline 80.0 & 6.3 & 6.6 & 7.1 & 7.2 & 6.8 & 7.0 & 6.8 & 6.9 & 6.8 & 6.7 & 6.6 & 6.9 & 6.9 & 7.0 \\
\hline 85.0 & -- & -- & -- & -- & -- & -- & -- & -- & -- & -- & -- & -- & 6.8 & - \\
\hline 90.0 & 6.0 & 6.1 & 7.1 & 7.2 & 7.0 & 6.9 & 7.0 & 5.9 & 6.6 & 6.6 & 6.7 & 6.7 & 6.7 & 7.0 \\
\hline 95.0 & -- & -- & -- & -- & -- & -- & -- & -- & - & -- & -- & -- & 6.5 & - \\
\hline 100.0 & 5.4 & 5.8 & 7.0 & 7.2 & 6.6 & 6.6 & 6.7 & 6.7 & 6.6 & 6.7 & 6.8 & 6.6 & 6.7 & 7.2 \\
\hline 102.0 & -- & -- & -- & -- & -- & -- & -- & -- & -- & -- & - & - & 6.8 & - \\
\hline 104.0 & -- & - & -- & -- & -- & -- & -- & -- & -- & -- & -- & -- & 6.9 & -- \\
\hline 105.0 & 4.3 & 5.1 & 7.0 & 6.6 & 6.8 & 6.9 & 6.5 & 6.8 & 6.7 & 6.7 & 6.8 & 6.8 & 6.6 & 7.2 \\
\hline 110.0 & 4.4 & 5.2 & 6.7 & 6.9 & 7.0 & 7.0 & 7.0 & 7.0 & 6.9 & 6.8 & 6.8 & 6.8 & 6.9 & 7.0 \\
\hline 113.0 & 5.4 & 5.2 & 6.7 & 6.8 & 7.0 & 6.9 & 6.9 & 6.8 & 6.8 & 6.7 & -- & 6.8 & - & 7.2 \\
\hline 114.0 & -- & -- & -- & -- & -- & -- & -- & -- & -- & -- & -- & -- & 6.8 & -- \\
\hline 115.0 & 6.6 & 7.4 & 6.7 & 6.8 & 6.9 & 7.0 & 6.9 & 7.1 & 6.9 & 7.0 & 7.1 & 7.0 & 7.3 & 7.2 \\
\hline 116.0 & -- & -- & -- & -- & -- & -- & -- & -- & -- & -- & -- & - & 9.7 & - \\
\hline 117.0 & 9.9 & 9.9 & 9.8 & 10.1 & 10.0 & 9.8 & 9.9 & 10.0 & 10.0 & 9.8 & 9.9 & 10.0 & -- & 9.6 \\
\hline 120.0 & -- & -- & -- & -- & -- & -- & -- & -- & -- & -- & -- & -- & 10.4 & -- \\
\hline 125.0 & 9.9 & 9.9 & 10.0 & 10.0 & 10.0 & 10.1 & 10.1 & 10.0 & 10.0 & 10.0 & 10.0 & 10.0 & -- & 10.2 \\
\hline 132.8 & -- & -- & -- & -- & -- & -- & -- & -- & -- & 9.7 & 10.2 & 9.8 & -- & 9.9 \\
\hline 133.0 & -- & - & -- & -- & -- & -- & -- & -- & -- & -- & -- & -- & 10.2 & -- \\
\hline
\end{tabular}


Table 18.--Summary of stream-channel cross-section data for selected sites on Fountain and Monument Creeks, water years 1985-88--Continued

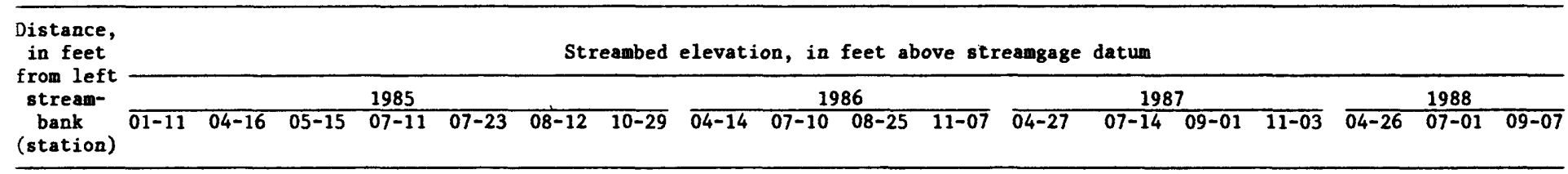

\section{FOUNTAIN CREEK AT COLORADO SPRINGS (DOWNSTREAM FROM NEVADA STREET, SITE F8)}

\begin{tabular}{|c|c|c|c|c|c|c|c|c|c|c|c|c|c|c|c|c|c|c|}
\hline $\begin{array}{l}4.0 \\
4.2 \\
6.0 \\
8.0 \\
9.2\end{array}$ & $\begin{array}{l}4.2 \\
3.6 \\
3.2 \\
2.7 \\
1.2\end{array}$ & $\begin{array}{l}3.6 \\
3.3 \\
3.0 \\
2.5 \\
1.8\end{array}$ & $\begin{array}{l}4.2 \\
4.1 \\
3.3 \\
2.7 \\
2.4\end{array}$ & $\begin{array}{l}3.5 \\
3.3 \\
3.0 \\
2.5 \\
1.8\end{array}$ & $\begin{array}{l}4.2 \\
3.6 \\
3.1 \\
2.6 \\
2.2\end{array}$ & $\begin{array}{l}4.0 \\
3.6 \\
3.1 \\
2.6 \\
2.1\end{array}$ & $\begin{array}{l}4.2 \\
3.8 \\
3.4 \\
3.1 \\
2.4\end{array}$ & $\begin{array}{l}4.2 \\
3.8 \\
3.4 \\
3.1 \\
2.5\end{array}$ & $\begin{array}{l}4.5 \\
4.3 \\
3.5 \\
3.1 \\
2.4\end{array}$ & $\begin{array}{r}4.4 \\
3.4 \\
3.0 \\
2.4\end{array}$ & $\begin{array}{r}4.5 \\
-- \\
3.5 \\
3.1 \\
2.6\end{array}$ & $\begin{array}{r}4.4 \\
-.5 \\
3.5 \\
3.1 \\
2.8\end{array}$ & $\begin{array}{r}4.5 \\
-.6 \\
3.6 \\
3.2 \\
2.7\end{array}$ & $\begin{array}{r}4.3 \\
-- \\
3.6 \\
3.2 \\
2.7\end{array}$ & $\begin{array}{l}4.7 \\
4.4 \\
3.6 \\
3.3 \\
2.7\end{array}$ & $\begin{array}{r}4.4 \\
-.6 \\
3.6 \\
3.1 \\
2.6\end{array}$ & $\begin{array}{c}4.6 \\
-- \\
-- \\
--\end{array}$ & $\begin{array}{r}4.4 \\
-.7 \\
3.7 \\
3.2 \\
2.8\end{array}$ \\
\hline $\begin{array}{l}10.0 \\
12.0 \\
14.0\end{array}$ & $\begin{array}{l}1.7 \\
0.4 \\
0.1\end{array}$ & $\begin{array}{l}1.1 \\
0.4 \\
0.1\end{array}$ & $\begin{array}{l}1.7 \\
0.8 \\
0.4\end{array}$ & $\begin{array}{l}1.6 \\
0.7 \\
0.3\end{array}$ & $\begin{array}{l}1.7 \\
1.1 \\
0.4\end{array}$ & $\begin{array}{r}1.7 \\
0.7 \\
-0.3\end{array}$ & $\begin{array}{l}2.1 \\
0.8 \\
0.4\end{array}$ & $\begin{array}{l}2.1 \\
1.2 \\
0.4\end{array}$ & $\begin{array}{l}2.1 \\
1.4 \\
1.0\end{array}$ & $\begin{array}{l}2.2 \\
1.6 \\
1.2\end{array}$ & $\begin{array}{l}2.1 \\
1.6 \\
1.2\end{array}$ & $\begin{array}{l}2.2 \\
1.6 \\
1.2\end{array}$ & $\begin{array}{l}2.2 \\
0.9 \\
1.4\end{array}$ & $\begin{array}{l}2.3 \\
1.9 \\
1.4\end{array}$ & $\begin{array}{l}2.5 \\
2.0 \\
1.5\end{array}$ & $\begin{array}{l}2.4 \\
1.6 \\
1.4\end{array}$ & $\begin{array}{r}2.5 \\
-.4 \\
1.4\end{array}$ & $\begin{array}{l}2.6 \\
2.1 \\
2.1\end{array}$ \\
\hline 17.0 & - & - & - & - & -- & - & -- & - & - & - & - & - & - & 1.0 & 1.0 & - & -- & -- \\
\hline 18.0 & -- & -- & -- & -- & -- & -- & -- & -- & -- & -- & -- & -- & 0.2 & 0.4 & -- & 0.6 & -- & -- \\
\hline 19.0 & -- & -- & -- & - & -- & -- & $\cdots$ & -- & $\cdots$ & -- & -- & -- & - & - & -- & - & 0.8 & $\cdots$ \\
\hline 19.5 & -- & -- & -- & -- & -- & -- & -- & -- & -- & -- & -- & -- & - & -- & -- & -- & 0.1 & -- \\
\hline 20.0 & -0.4 & -0.4 & -0.5 & -0.7 & -0.6 & -0.8 & -0.8 & -0.9 & -0.2 & -1.6 & -0.2 & -0.2 & -- & -0.1 & -0.5 & -0.4 & -- & 0.1 \\
\hline 24.0 & & -- & -- & -- & -- & -- & -- & -- & -- & -- & - & -- & -0.4 & -0.5 & -- & - & -- & -- \\
\hline 25.0 & -0.8 & -0.8 & -0.7 & -0.8 & -1.2 & -1.0 & -0.9 & -0.8 & -0.6 & -0.8 & -0.8 & -0.8 & -0.6 & -0.6 & -0.6 & -0.6 & -0.3 & 0.1 \\
\hline 26.0 & - & - & -- & -- & -- & -- & -- & -- & -- & -- & -- & -- & -- & -- & - & -- & -- & 0.0 \\
\hline 30.0 & -1.0 & -1.0 & -1.1 & -1.2 & -1.5 & -1.0 & -1.4 & -1.2 & -0.4 & -0.4 & -0.9 & -1.1 & -1.3 & -1.0 & -1.0 & -0.9 & -0.3 & -0.1 \\
\hline 34.0 & -1.3 & -1.3 & -1.5 & -1.4 & -1.7 & -1.2 & -1.3 & -1.3 & -0.6 & -0.6 & -1.0 & -1.1 & -1.4 & -1.1 & -1.1 & -1.2 & - & -0.2 \\
\hline 35.0 & -- & - & -- & -- & -- & -- & - & -- & -- & - & -- & - & -- & -- & - & -- & -0.3 & -- \\
\hline 37.0 & -1.6 & -1.6 & -1.6 & -1.5 & -1.7 & -1.2 & -1.5 & -1.4 & -0.8 & -0.6 & -0.9 & -1.1 & -1.4 & -1.0 & -1.3 & -1.0 & -- & -0.3 \\
\hline 40.0 & -1.4 & -1.7 & -1.7 & -1.5 & -1.7 & -1.3 & -1.5 & -1.4 & -0.8 & -0.6 & -0.9 & -1.4 & -1.6 & -1.0 & -1.1 & -1.1 & -0.6 & 0.0 \\
\hline 45.0 & -1.5 & -1.6 & -1.3 & -1.6 & -1.8 & -1.4 & -1.6 & -1.4 & -0.8 & -0.8 & -1.1 & -1.2 & -1.4 & -1.2 & -1.2 & -1.1 & -0.3 & 0.0 \\
\hline 47.0 & -- & - & -- & -- & -- & -- & -- & -- & -- & -- & -- & -- & -- & $=$ & -- & -- & -- & 0.0 \\
\hline $\begin{array}{l}50.0 \\
55.0\end{array}$ & $\begin{array}{l}-1.5 \\
-1.4\end{array}$ & $\begin{array}{l}-1.4 \\
-1.4\end{array}$ & $\begin{array}{l}-1.5 \\
-1.3\end{array}$ & $\begin{array}{l}-1.4 \\
-1.1\end{array}$ & $\begin{array}{l}-1.6 \\
-1.4\end{array}$ & $\begin{array}{l}-1.3 \\
-0.9\end{array}$ & $\begin{array}{l}-1.6 \\
-1.2\end{array}$ & $\begin{array}{l}-1.5 \\
-1.2\end{array}$ & $\begin{array}{l}-0.7 \\
-0.7\end{array}$ & $\begin{array}{l}-0.8 \\
-0.8\end{array}$ & $\begin{array}{l}-1.2 \\
-0.8\end{array}$ & $\begin{array}{l}-1.1 \\
-1.0\end{array}$ & $\begin{array}{l}-1.2 \\
-1.2\end{array}$ & $\begin{array}{l}-1.2 \\
-0.9\end{array}$ & $\begin{array}{l}-1.3 \\
-1.1\end{array}$ & $\begin{array}{l}-1.0 \\
-0.8\end{array}$ & $\begin{array}{l}-0.2 \\
-0.7\end{array}$ & $\begin{array}{l}-0.2 \\
-0.3\end{array}$ \\
\hline 57.5 & -- & -- & -- & -. & -- & -- & -- & -- & -- & -- & -- & -- & -- & -- & -- & -- & -0.8 & -- \\
\hline 60.0 & -1.0 & -1.0 & -1.1 & -1.2 & -1.3 & -0.9 & -0.8 & -1.0 & -0.6 & -0.8 & -0.8 & -0.8 & -0.6 & -0.8 & -0.4 & -0.7 & -0.7 & -0.2 \\
\hline 62.0 & - & -- & - & - & - & - & - & - & -- & $=$ & $=$ & $=$ & -0.6 & -0.4 & - & - & -0.1 & -- \\
\hline 65.0 & -0.9 & -1.1 & -1.3 & -1.2 & -1.1 & -0.7 & -1.1 & -1.1 & -0.6 & 0.0 & -0.7 & -0.8 & -0.4 & -0.6 & -0.6 & -0.6 & 0.0 & -0.1 \\
\hline 67.0 & -- & -- & -- & - & -- & - & -- & -- & -- & - & -- & -- & - & -- & -- & -- & 0.1 & -- \\
\hline 68.0 & -1.1 & -1.2 & -1.2 & -1.1 & -1.4 & -0.7 & -1.1 & -1.1 & -0.4 & -0.2 & -0.7 & -0.8 & -0.4 & -0.5 & -0.7 & -0.6 & -- & -0.1 \\
\hline 70.0 & -- & -- & -- & - & -- & - & - & - & $=$ & - & - & - & - & -0.5 & -0.6 & -0.4 & -0.1 & -- \\
\hline 71.0 & -- & -- & -- & -- & -- & -- & -- & - & - & - & - & - & - & -- & - & - & - & 0.0 \\
\hline 72.0 & -0.5 & -0.5 & -0.7 & -0.8 & -1.1 & -0.7 & -0.6 & -0.7 & -0.3 & 0.0 & -0.3 & -0.3 & 0.0 & -0.4 & -0.4 & -0.3 & - & 0.0 \\
\hline 75.0 & -0.1 & -0.3 & -0.1 & -0.5 & -0.3 & -0.4 & 0.0 & 0.0 & 0.0 & -0.2 & 0.0 & 0.0 & 0.2 & 0.0 & 0.0 & 0.0 & 0.3 & 0.2 \\
\hline $\begin{array}{l}77.0 \\
79.0\end{array}$ & $\begin{array}{l}-0.6 \\
-0.9\end{array}$ & $\begin{array}{l}-0.7 \\
-0.9\end{array}$ & $\begin{array}{l}-0.7 \\
-1.0\end{array}$ & $\begin{array}{l}-0.8 \\
-1.1\end{array}$ & $\begin{array}{l}-0.7 \\
-0.8\end{array}$ & $\begin{array}{l}-0.4 \\
-0.7\end{array}$ & $\begin{array}{r}0.0 \\
-0.1\end{array}$ & $\begin{array}{l}-0.1 \\
-0.2\end{array}$ & $\begin{array}{l}-0.2 \\
-0.1\end{array}$ & $\begin{array}{l}0.0 \\
0.0\end{array}$ & $\begin{array}{r}-0.1 \\
0.3\end{array}$ & $\begin{array}{r}-0.2 \\
0.0\end{array}$ & $\begin{array}{l}0.2 \\
0.2\end{array}$ & $\begin{array}{r}0.0 \\
-0.1\end{array}$ & $\begin{array}{r}0.1 \\
-0.1\end{array}$ & $\begin{array}{l}-0.1 \\
-0.2\end{array}$ & $=$ & $\begin{array}{l}0.1 \\
0.1\end{array}$ \\
\hline 80.0 & - & -- & - & - & - & - & - & - & - & - & - & -- & - & - & - & $\ldots$ & 0.0 & - \\
\hline 85.0 & -- & - & -- & -- & -- & -- & -- & -- & -- & -- & - & -- & -0.3 & -0.3 & -- & -0.4 & -0.2 & -- \\
\hline 89.0 & -0.2 & -0.2 & -1.0 & -1.0 & -0.7 & 0.4 & -0.3 & -0.3 & -0.2 & -0.2 & -0.6 & 0.1 & -0.4 & -0.8 & -0.7 & -0.8 & -0.5 & 0.0 \\
\hline 90.0 & -- & - & - & -- & - & - & -- & -- & -- & -- & - & -- & - & -- & -- & - & 0.5 & -- \\
\hline 91.0 & 0.6 & 0.6 & 0.4 & 0.5 & 0.4 & 0.9 & 0.6 & 0.5 & 0.5 & 0.6 & 0.6 & 0.6 & 0.6 & 0.6 & 0.8 & 0.5 & - & 1.0 \\
\hline 93.0 & -- & -- & -- & -- & -- & -- & -- & -- & -- & -- & -- & -- & -- & -- & -- & -- & 1.2 & -- \\
\hline 95.0 & - & -- & - & - & -- & - & -- & - & -- & -- & -- & -- & -- & - & -- & - & 3.3 & -- \\
\hline 95.5 & 3.2 & 3.3 & 3.1 & 3.2 & 3.2 & 3.2 & 3.3 & 3.1 & 3.1 & 3.2 & 3.1 & 3.2 & 3.2 & 3.2 & 3.2 & 3.2 & $\cdots$ & 3.3 \\
\hline 100.0 & -- & -- & -- & -- & -- & -- & -- & -- & -- & -- & -- & - & -- & - & -- & -- & - & - \\
\hline 101.7 & 3.4 & 3.3 & 3.2 & 3.2 & 3.2 & 3.2 & 3.3 & 3.2 & 3.3 & 3.2 & 3.3 & 3.6 & 3.3 & 3.6 & 3.6 & 3.3 & - & 3.6 \\
\hline
\end{tabular}


Table 18.--sumarg of strua-channol cross-section data for solected aitos on Fountain and Nonument Cruaks, water gears 1985-88--Continued

\begin{tabular}{|c|c|c|c|c|c|c|c|c|c|c|c|c|c|c|c|c|c|c|c|}
\hline \multirow{3}{*}{$\begin{array}{l}\text { Distance, } \\
\text { in feet } \\
\text { from left } \\
\text { atrean- } \\
\text { bank } \\
\text { (station) }\end{array}$} & \multicolumn{19}{|c|}{ Streabed elevation, in feet above atreangage datum } \\
\hline & \multicolumn{7}{|c|}{1985} & \multicolumn{4}{|c|}{1986} & \multicolumn{4}{|c|}{1987} & \multicolumn{4}{|c|}{1988} \\
\hline & $\overline{01-1}$ & $\overline{04-16}$ & 05-15 & 07-11 & $07-23$ & 08-12 & $10-29$ & $\overline{04-14}$ & $\overline{07-11}$ & 08-26 & 11-07 & $\overline{04-28}$ & $07-15$ & 08-27 & $\overline{11-03}$ & $\overline{04-26}$ & $06-15$ & $07-01$ & 09-07 \\
\hline \multicolumn{20}{|c|}{ 07105800 FOUNTAIN CRREK AT SECURITY (SITE F13) } \\
\hline $\begin{array}{r}0.0 \\
12.0\end{array}$ & $\begin{array}{l}8.1 \\
6.0\end{array}$ & $\begin{array}{l}8.2 \\
6.0\end{array}$ & $\begin{array}{l}8.1 \\
5.9\end{array}$ & $\begin{array}{l}8.1 \\
5.9\end{array}$ & $\begin{array}{l}8.1 \\
6.0\end{array}$ & $\begin{array}{l}8.1 \\
6.0\end{array}$ & $\begin{array}{l}8.1 \\
6.1\end{array}$ & $\begin{array}{l}8.1 \\
5.9\end{array}$ & $\begin{array}{l}8.1 \\
6.0\end{array}$ & $\begin{array}{l}8.1 \\
5.9\end{array}$ & $\begin{array}{l}8.1 \\
6.0\end{array}$ & $\begin{array}{l}8.2 \\
6.0\end{array}$ & $\begin{array}{l}8.5 \\
6.0\end{array}$ & $\begin{array}{l}8.2 \\
5.9\end{array}$ & $\begin{array}{l}8.5 \\
6.0\end{array}$ & $\begin{array}{l}8.2 \\
6.0\end{array}$ & $\begin{array}{r}8.5 \\
--\end{array}$ & $\begin{array}{r}8.2 \\
-\end{array}$ & $\begin{array}{l}8.5 \\
6.0\end{array}$ \\
\hline 14.0 & -- & -- & $\cdots$ & - & -- & -- & -- & -- & -- & $\ldots$ & - & - & -- & - & - & - & 5.7 & 5.8 & - \\
\hline 20.0 & 5.3 & 5.4 & 5.3 & 5.3 & 5.4 & 5.4 & 5.5 & 5.3 & 5.4 & 5.3 & 5.3 & 5.3 & 5.3 & 5.3 & 5.2 & 5.4 & - & $=$ & 5.3 \\
\hline 21.0 & $=$ & - & - & - & -- & -- & - & - & - & -- & - & - & - & $\ldots$ & - & - & 5.1 & 5.1 & $\ldots$ \\
\hline $\begin{array}{l}24.0 \\
25.5\end{array}$ & $\begin{array}{l}2.9 \\
0.9\end{array}$ & $\begin{array}{l}3.5 \\
0.8\end{array}$ & $\begin{array}{l}3.3 \\
1.7\end{array}$ & $\begin{array}{l}3.3 \\
0.8\end{array}$ & $\begin{array}{l}3.5 \\
2.2\end{array}$ & $\begin{array}{l}3.4 \\
2.5\end{array}$ & $\begin{array}{l}3.6 \\
2.3\end{array}$ & $\begin{array}{l}3.2 \\
1.8\end{array}$ & $\begin{array}{l}3.6 \\
1.6\end{array}$ & $\begin{array}{l}3.6 \\
1.8\end{array}$ & $\begin{array}{l}3.4 \\
2.5\end{array}$ & $\begin{array}{l}3.5 \\
1.9\end{array}$ & $\begin{array}{l}3.5 \\
1.8\end{array}$ & $\begin{array}{l}3.6 \\
1.6\end{array}$ & $\begin{array}{l}3.0 \\
1.6\end{array}$ & $\begin{array}{l}3.7 \\
2.2\end{array}$ & $\begin{array}{r}3.5 \\
--\end{array}$ & $\begin{array}{r}3.6 \\
0 .\end{array}$ & $\begin{array}{l}3.3 \\
2.3\end{array}$ \\
\hline 26.0 & $\because$ & - & $\because$ & - & - & - & $=$ & - & $\ldots$ & $\ldots$ & $\cdots$ & - & - & - & - & $=$ & 2.0 & 2.0 & $=$ \\
\hline 26.5 & - & - & - & - & -- & - & -- & -- & - & -- & - & -- & -- & -- & -- & -- & 1.0 & - & -- \\
\hline 27.0 & - & -- & -- & -- & -- & -- & -- & -- & -- & -- & - & - & -- & -- & - & -- & 0.7 & 0.8 & 0.7 \\
\hline 28.0 & 1.1 & 0.8 & 1.8 & 1.1 & 0.9 & 1.0 & 1.6 & 1.7 & 1.4 & 1.0 & 0.9 & 0.8 & 0.7 & 0.7 & 0.8 & 0.8 & -- & -- & 0.7 \\
\hline 30.0 & - & $=$ & $=$ & $\because$ & - & - & - & - & -- & - & - & - & - & - & -- & - & 0.6 & 0.6 & -- \\
\hline 32.0 & 1.9 & 1.2 & 1.9 & 1.6 & 1.0 & 1.1 & 1.9 & 1.9 & 1.8 & 1.4 & 0.9 & 0.8 & 0.6 & 0.6 & 0.7 & 0.6 & - & - & 0.5 \\
\hline 33.0 & - & - & -- & -- & - & -- & -- & -- & -- & - & -- & -- & -- & - & -- & - & -- & -- & 0.5 \\
\hline 35.0 & - & - & - & -- & - & -- & -- & -- & -- & -- & -- & -- & -- & -- & - & -- & 0.4 & 0.4 & - \\
\hline 40.0 & 2.1 & 1.4 & 1.3 & 1.8 & 0.7 & 0.7 & 1.8 & 1.8 & 1.7 & 0.7 & 0.6 & 0.6 & 0.4 & 0.4 & 0.6 & 0.3 & 0.4 & 0.4 & 0.4 \\
\hline 45.0 & - & -- & - & - & - & - & - & - & - & $\cdots$ & $=$ & - & - & - & - & - & 0.1 & 0.2 & - \\
\hline 50.0 & 1.9 & 1.1 & 0.9 & 1.5 & 0.7 & 1.2 & 1.1 & 0.5 & 0.4 & 0.3 & 0.3 & 0.2 & 0.5 & 0.5 & 0.8 & -0.1 & 0.03 & -0.1 & -0.2 \\
\hline 55.0 & $\cdots$ & - & - & - & - & $=$ & - & - & - & $\cdots$ & -- & -- & - & - & - & - & 0.1 & 0.2 & $=$ \\
\hline 60.0 & 1.9 & 1.3 & 0.7 & 1.4 & 1.0 & 1.7 & 0.9 & 0.4 & 0.8 & 0.5 & 0.4 & 0.4 & 0.8 & 0.7 & 0.8 & 0.1 & 0.2 & 0.5 & 0.0 \\
\hline 65.0 & $\ddot{0}$ & 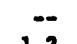 & $\ddot{0}$ & 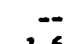 & $\because$ & $\because$ & $\because$ & - & $-\overline{0}$ & 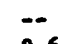 & $\ddot{-}$ & $-\overline{0}$ & $\because$ & - & $\rightarrow$ & - & 0.2 & 0.0 & 0.3 \\
\hline 70.0 & 1.9 & 1.2 & 0.8 & 1.6 & 1.1 & 1.8 & 1.2 & 0.6 & 0.8 & 0.6 & 1.0 & 0.3 & 1.2 & 0.8 & 0.8 & 0.7 & 0.3 & 0.2 & 0.4 \\
\hline 75.0 & $=$ & - & 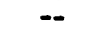 & -- & -- & -- & $=$ & -- & -- & $\ldots$ & - & - & $=$ & - & - & - & 0.3 & 0.4 & 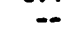 \\
\hline 80.0 & 2.0 & 1.1 & 1.1 & 1.6 & 1.1 & 1.6 & 1.1 & 0.6 & 0.6 & 0.7 & 1.2 & 0.6 & 1.4 & 0.8 & 1.2 & 0.9 & 0.6 & 0.7 & 0.5 \\
\hline 85.0 & -- & -- & -- & -- & -- & -- & -- & -- & -- & -- & -- & -- & - & -- & -- & - & 1.0 & 1.0 & -- \\
\hline 88.5 & - & -- & -- & - & -- & - & - & - & -- & -- & -- & -- & -- & -- & -- & -- & 1.0 & -- & -. \\
\hline 90.0 & 2.1 & 1.4 & 1.2 & 1.9 & 0.9 & 1.1 & 1.1 & 0.6 & 0.7 & 0.8 & 1.3 & 0.9 & 1.4 & 0.9 & 1.5 & 1.9 & 1.1 & 1.1 & 0.0 \\
\hline 95.0 & -- & - & $\cdots$ & - & $=$ & -- & $=$ & - & - & $\ldots$ & $=$ & - & - & -- & $\ldots$ & - & 1.2 & 1.1 & $\ldots$ \\
\hline 100.0 & 2.3 & 1.7 & 1.2 & 1.8 & 0.7 & 1.1 & 1.1 & 0.8 & 0.8 & 0.8 & 1.5 & 0.9 & 0.5 & 1.4 & 1.6 & 1.6 & 1.3 & 1.2 & 0.7 \\
\hline 105.0 & $\cdots$ & -- & -- & - & - & - & - & -- & -- & -- & - & - & $=$ & - & - & $=$ & 1.2 & 1.2 & $=$ \\
\hline 109.3 & $\cdots$ & - & - & - & - & - & - & - & - & - & - & $=$ & - & - & - & - & -- & -- & 0.7 \\
\hline 110.0 & - & - & - & -- & $\ldots$ & -- & - & -- & -- & -. & - & -- & -- & -- & -- & -- & 0.8 & 0.9 & 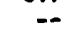 \\
\hline 111.0 & 2.1 & 1.8 & 1.4 & 1.6 & 1.2 & 1.1 & 1.2 & 1.2 & 1.2 & 1.2 & 1.2 & 0.2 & 1.1 & 1.1 & 1.4 & 1.3 & - & $=$ & 1.1 \\
\hline 111.5 & 3.3 & 3.6 & 3.1 & 2.9 & 2.3 & 2.4 & 2.3 & 3.7 & 3.3 & 3.1 & 3.8 & - & 3.1 & 3.6 & 3.7 & 3.0 & 1.2 & 1.1 & 3.2 \\
\hline 112.0 & - & -- & -- & -- & - & -- & -- & -- & - & $=$ & -- & -- & - & -- & - & - & 3.8 & 3.1 & - \\
\hline 115.0 & 5.4 & 5.6 & 5.5 & 5.3 & 5.3 & 5.3 & - & - & -- & 5.4 & 5.4 & -- & - & - & - & -- & 5.4 & 5.4 & - \\
\hline 120.0 & 6.8 & 6.6 & 6.8 & 6.7 & 6.8 & 6.7 & 6.7 & 6.7 & 6.8 & 6.8 & 6.7 & 6.8 & 6.8 & 6.7 & 6.8 & 6.8 & 6.8 & 6.8 & 6.8 \\
\hline $\begin{array}{l}122.8 \\
122.9\end{array}$ & $\begin{array}{l}7.4 \\
--.\end{array}$ & $\begin{array}{l}7.4 \\
-.-\end{array}$ & $\begin{array}{l}7.4 \\
-.-\end{array}$ & $\begin{array}{l}7.5 \\
-.-\end{array}$ & $\begin{array}{r}7.6 \\
-\end{array}$ & $\begin{array}{r}7.3 \\
-\end{array}$ & 7.1 & $\begin{array}{r}7.5 \\
-\end{array}$ & 7.6 & $\begin{array}{l}7.4 \\
-0\end{array}$ & $\begin{array}{r}7.6 \\
\end{array}$ & $\begin{array}{r}7.6 \\
-\end{array}$ & $\begin{array}{r}7.6 \\
-\end{array}$ & $\begin{array}{r}7.4 \\
-\end{array}$ & $\begin{array}{r}7.6 \\
-\end{array}$ & $\begin{array}{r}7.5 \\
-\end{array}$ & $\overline{7.5}$ & $\overline{4}$ & $\begin{array}{r}7.4 \\
-\end{array}$ \\
\hline
\end{tabular}


Table 18.--Sumbary of stream-channel cross-section data for selected sites on Fountain and Nonument Creeks, water years 1985-88--Continued

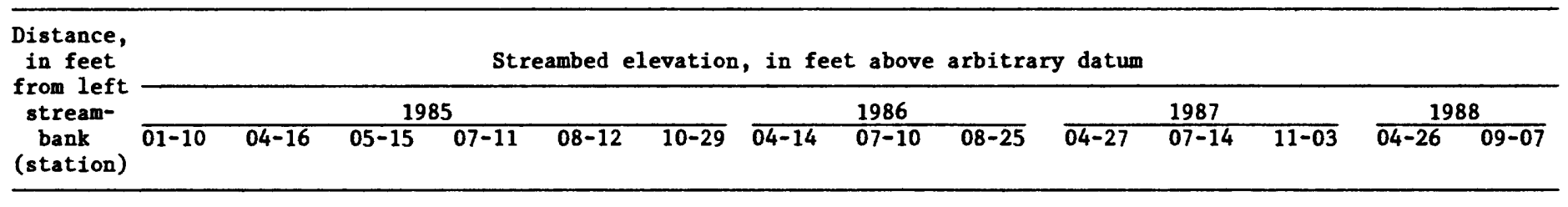

07103780 MONUMENT CREEK ABOVE NORTH GATE BOULEVARD AT U.S. AIR FORCE ACADEMY (SITE M5)

\begin{tabular}{|c|c|c|c|c|c|c|c|c|c|c|c|c|c|c|}
\hline $\begin{array}{r}0.0 \\
4.0 \\
8.0 \\
11.0 \\
12.5\end{array}$ & $\begin{array}{l}12.5 \\
12.3 \\
12.0 \\
11.4 \\
11.0\end{array}$ & $\begin{array}{l}12.5 \\
12.2 \\
12.0 \\
11.5 \\
10.7\end{array}$ & $\begin{array}{l}12.4 \\
12.2 \\
11.9 \\
11.4 \\
11.0\end{array}$ & $\begin{array}{l}12.5 \\
12.2 \\
11.9 \\
11.4 \\
10.9\end{array}$ & $\begin{array}{l}12.5 \\
12.1 \\
11.9 \\
11.5 \\
10.7\end{array}$ & $\begin{array}{l}12.5 \\
12.1 \\
11.9 \\
11.4 \\
10.7\end{array}$ & $\begin{array}{l}12.5 \\
12.1 \\
11.9 \\
11.3 \\
10.9\end{array}$ & $\begin{array}{l}12.5 \\
12.1 \\
11.8 \\
11.4 \\
11.0\end{array}$ & $\begin{array}{l}12.5 \\
12.2 \\
11.8 \\
11.4 \\
10.9\end{array}$ & $\begin{array}{l}12.8 \\
12.2 \\
11.8 \\
11.4 \\
10.6\end{array}$ & $\begin{array}{l}12.6 \\
12.2 \\
11.9 \\
11.4 \\
11.0\end{array}$ & $\begin{array}{l}12.6 \\
12.1 \\
11.9 \\
11.4 \\
10.9\end{array}$ & $\begin{array}{l}12.6 \\
12.2 \\
11.9 \\
11.4 \\
10.9\end{array}$ & $\begin{array}{l}12.6 \\
12.1 \\
11.9 \\
11.4 \\
10.9\end{array}$ \\
\hline $\begin{array}{l}15.0 \\
18.0 \\
21.0 \\
23.0 \\
24.0\end{array}$ & $\begin{array}{r}10.2 \\
9.5 \\
8.7 \\
8.4 \\
-.\end{array}$ & $\begin{array}{r}10.1 \\
9.4 \\
8.5 \\
8.2 \\
-.\end{array}$ & $\begin{array}{r}9.8 \\
8.8 \\
8.3 \\
8.1 \\
.-\end{array}$ & $\begin{array}{r}9.9 \\
8.8 \\
8.2 \\
8.1 \\
-.-\end{array}$ & $\begin{array}{r}9.9 \\
8.7 \\
8.2 \\
8.1 \\
-.-\end{array}$ & $\begin{array}{r}9.6 \\
8.7 \\
8.1 \\
8.1 \\
.-\end{array}$ & $\begin{array}{r}9.9 \\
8.7 \\
8.1 \\
8.0 \\
-.\end{array}$ & $\begin{array}{r}9.9 \\
8.8 \\
8.1 \\
8.0 \\
-.\end{array}$ & $\begin{array}{r}9.6 \\
8.7 \\
8.1 \\
8.0 \\
.-\end{array}$ & $\begin{array}{r}9.8 \\
8.8 \\
8.2 \\
8.0 \\
--\end{array}$ & $\begin{array}{r}8.8 \\
7.8 \\
8.2 \\
6.8 \\
--\end{array}$ & $\begin{array}{r}9.7 \\
8.8 \\
8.1 \\
7.6 \\
-.\end{array}$ & $\begin{array}{r}9.8 \\
8.9 \\
8.3 \\
7.7 \\
-.\end{array}$ & $\begin{array}{l}9.9 \\
8.8 \\
8.3 \\
7.7 \\
7.4\end{array}$ \\
\hline $\begin{array}{l}25.0 \\
27.0 \\
29.0 \\
31.0 \\
33.0\end{array}$ & $\begin{array}{l}8.0 \\
7.6 \\
7.5 \\
7.0 \\
7.3\end{array}$ & $\begin{array}{l}7.9 \\
7.8 \\
7.4 \\
7.5 \\
7.2\end{array}$ & $\begin{array}{l}7.9 \\
7.6 \\
7.3 \\
7.2 \\
6.9\end{array}$ & $\begin{array}{l}7.7 \\
7.3 \\
7.2 \\
7.0 \\
6.9\end{array}$ & $\begin{array}{l}7.7 \\
7.5 \\
7.2 \\
7.2 \\
6.9\end{array}$ & $\begin{array}{l}7.7 \\
7.5 \\
7.3 \\
7.1 \\
6.9\end{array}$ & $\begin{array}{l}7.7 \\
7.4 \\
7.1 \\
7.1 \\
6.8\end{array}$ & $\begin{array}{l}7.7 \\
7.4 \\
7.2 \\
7.0 \\
7.2\end{array}$ & $\begin{array}{l}7.6 \\
7.4 \\
7.2 \\
7.0 \\
6.8\end{array}$ & $\begin{array}{l}7.6 \\
7.2 \\
7.0 \\
7.1 \\
6.9\end{array}$ & $\begin{array}{l}7.4 \\
7.1 \\
7.0 \\
7.1 \\
7.1\end{array}$ & $\begin{array}{l}7.4 \\
7.1 \\
7.0 \\
7.1 \\
7.0\end{array}$ & $\begin{array}{l}7.5 \\
7.0 \\
7.1 \\
7.1 \\
7.1\end{array}$ & $\begin{array}{l}7.3 \\
7.0 \\
7.0 \\
7.1 \\
7.0\end{array}$ \\
\hline $\begin{array}{l}35.0 \\
35.5 \\
36.5 \\
37.5 \\
41.0\end{array}$ & $\begin{array}{r}7.5 \\
-. \\
8.0 \\
8.6 \\
9.7\end{array}$ & $\begin{array}{r}7.2 \\
-- \\
8.1 \\
9.0 \\
9.1\end{array}$ & $\begin{array}{r}6.6 \\
-- \\
8.3 \\
8.4 \\
9.4\end{array}$ & $\begin{array}{r}6.7 \\
-. \\
8.5 \\
8.7 \\
9.7\end{array}$ & $\begin{array}{r}6.8 \\
- \\
8.4 \\
9.0 \\
9.4\end{array}$ & $\begin{array}{r}6.7 \\
-- \\
8.5 \\
8.8 \\
9.1\end{array}$ & $\begin{array}{r}6.7 \\
-. \\
8.0 \\
8.9 \\
9.4\end{array}$ & $\begin{array}{r}6.6 \\
-- \\
8.0 \\
9.0 \\
9.6\end{array}$ & $\begin{array}{r}6.7 \\
-- \\
8.1 \\
8.9 \\
9.4\end{array}$ & $\begin{array}{c}6.7 \\
- \\
7.1 \\
8.3 \\
-\end{array}$ & $\begin{array}{r}7.0 \\
-- \\
6.8 \\
8.0 \\
9.0\end{array}$ & $\begin{array}{l}7.0 \\
-- \\
7.9 \\
8.0 \\
9.0\end{array}$ & $\begin{array}{l}6.7 \\
-. \\
7.9 \\
7.8 \\
8.9\end{array}$ & $\begin{array}{l}6.9 \\
7.3 \\
8.0 \\
8.5 \\
9.6\end{array}$ \\
\hline $\begin{array}{l}44.0 \\
46.0 \\
50.6\end{array}$ & $\begin{array}{r}-- \\
11.2 \\
12.1\end{array}$ & $\begin{array}{r}-. \\
11.3 \\
12.0\end{array}$ & $\begin{array}{r}-. \\
11.2 \\
12.0\end{array}$ & $\begin{array}{r}-- \\
11.2 \\
12.0\end{array}$ & $\begin{array}{r}-- \\
11.2 \\
12.0\end{array}$ & $\begin{array}{r}-- \\
11.2 \\
12.0\end{array}$ & $\begin{array}{r}-. \\
11.2 \\
12.0\end{array}$ & $\begin{array}{r}-. \\
11.1 \\
12.0\end{array}$ & $\begin{array}{r}-. \\
11.1 \\
12.1\end{array}$ & $\begin{array}{r}9.6 \\
10.0 \\
12.0\end{array}$ & $\begin{array}{r}-. \\
11.1 \\
12.0\end{array}$ & $\begin{array}{r}-- \\
11.1 \\
12.0\end{array}$ & $\begin{array}{r}-- \\
11.2 \\
12.0\end{array}$ & $\begin{array}{r}- \\
11.1 \\
12.0\end{array}$ \\
\hline
\end{tabular}


Table 18.--Summary of stream-channel cross-section data for selected sites on Fountain and Monument Creeks, water years 1985-88--Continued

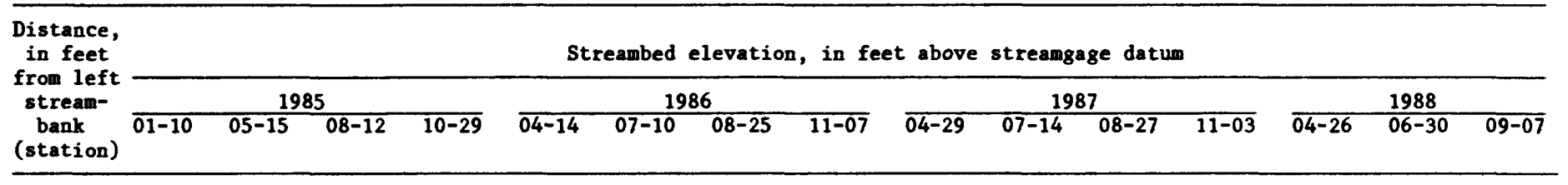

07104000 MONUMENT CREEK AT PIKEVIEW (SITE M10)

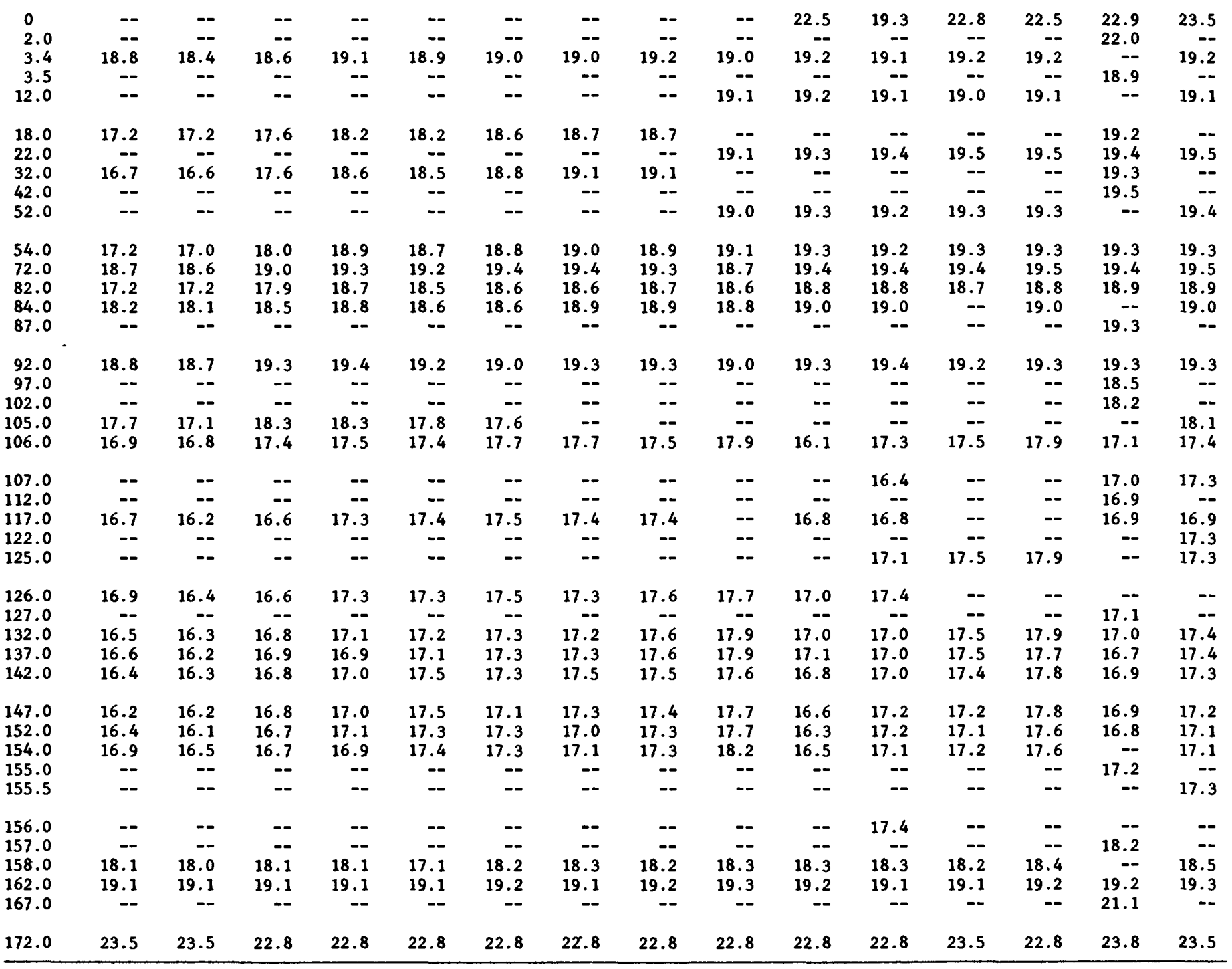


Table 19.--Species list, replicate samples, and mean density of benthic invertebrates for selected sites on Fountain and Monument Creeks

[Densities are rounded to standard significant figures

(Britton and Greeson, 1989)]

\begin{tabular}{cccc} 
Taxa & $\begin{array}{c}\text { Replicate sample, } \\
\text { number of organisms }\end{array}$ & $\begin{array}{c}\text { Mean density, } \\
\text { numbers of organisms } \\
\text { per square meter }\end{array}$ \\
\cline { 2 - 4 } & 07103700 FOUNTAIN CREEK NEAR COLORADO SPRINGS (SITE F4) \\
\hline SAMPLE DATE: APRIL 16, 1985
\end{tabular}

INSECTA

Ephemeroptera (mayflies)

Callibaetis sp.

Epeorus longimanus

Ephemerella inermis

3

2

2

1

0

3

0

25

0

0

7

Plecoptera (stoneflies)

Chloroperlidae

2

0

0

7

Diptera (true flies)

Cricotopus $\mathrm{sp}$.

Diamesa sp.

Micropsectra sp.

Orthocladius sp.

Thienemanniella sp.

Chironomidae pupa

$\begin{array}{rr}64 & 26 \\ 9 & 8 \\ 1 & \\ 13 & 6 \\ 1 & \\ 7 & \end{array}$

26

15

380

86

$0 \quad 0$

83

$\begin{array}{ll}6 & 7\end{array}$

$0 \quad 0$

4

93

0

4

29

COLLEMBOLA (springtails)

Isotomurus palustris

1

1

0

7

OLIGOCHAETA (worms)

Limnodrilus $\mathrm{sp}$.

140

21

9

600

TOTAL

240

63

41

1,200 
Table 19.--Species list, replicate samples, and mean density of benthic invertebrates for selected sites on Fountain and Monument Creeks--Continued

Taxa

Replicate sample, number of organisms
Mean density, numbers of organisms per square meter

\section{FOUNTAIN CREEK NEAR COLORADO SPRINGS (SITE F4)}

\section{Sample Date: July 11, 1985}

INSECTA

Ephemeroptera (mayflies)

Ameletus cooki
Baetis tricaudatus
Cinygmula sp.
Drunella grandis grandis
Epeorus longimanus
Ephemerella infrequens

$\begin{array}{rrrr}2 & 0 & 2 & 14\end{array}$

$\begin{array}{llll}60 & 60 & 100 & 790\end{array}$

$\begin{array}{llll}12 & 4 & 2 & 65\end{array}$

$\begin{array}{llll}0 & 0 & 2 & 7\end{array}$

$\begin{array}{llll}0 & 2 & 0 & 7\end{array}$

Ephemerella infrequens

Plecoptera (stoneflies)

Amphinemura banksi

Isoperla sobria

$0-0$

8

Pteronarcella badia

Chloroperlidae

Trichoptera (caddisflies)

Glossosoma sp.

Hydropsyche $\mathrm{sp}$.

0

0

0

7

Lepidoptera (aquatic caterpillars)

Parargyractis sp.

Diptera (true flies)

Boreoheptagyia sp.

Chelifera sp.

Cricotopus sp.

Diamesa sp.

Micropsectra sp.

Orthocladius sp.

Parametriocnemus sp.

Psychoda sp.

Thienemanniella sp.

Thienemannimyia sp. group

Tipula sp.

Chironomidae pupa

$\begin{array}{rrr}4 & 0 & \\ 0 & 0 & \\ 36 & 34 & 12 \\ 2 & 2 & \\ 2 & 4 & \\ 40 & 14 & 10 \\ 62 & 58 & 5 \\ 2 & 0 & \\ 0 & 2 & \\ 6 & 0 & \\ 0 & 0 & \\ 8 & 2 & \end{array}$

14

7

290

14

29

230

630

7

29

29

7

36

OLIGOCHAETA (worms)

Limodrilus sp.

Lumbricidae

TOTAL
300
$-\quad 0$

550
$440 \quad 1,000$

1

6301,200

8,800 
Table 19.--Species list, replicate samples, and mean density of benthic invertebrates for selected sites on Fountain and Monument Creeks--Continued

\begin{tabular}{|c|c|c|c|}
\hline \multirow[t]{2}{*}{ Taxa } & $\begin{array}{l}\text { Replicate } \\
\text { number of }\end{array}$ & & \multirow{2}{*}{$\begin{array}{l}\text { Mean density, } \\
\text { numbers of organisms } \\
\text { per square meter }\end{array}$} \\
\hline & $\begin{array}{ll}1 & 2\end{array}$ & 3 & \\
\hline
\end{tabular}

07103700 FOUNTAIN CREEK NEAR COLORADO SPRINGS (SITE F4)

Sample Date: August 12, 1985

INSECTA

$\begin{array}{lrrrr}\text { Ephemeroptera (mayflies) } & & & \\ \text { Baetis tricaudatus } & 39 & 90 & 14 & 510 \\ \text { Drunella doddsi } & 0 & 1 & 0 & 4 \\ \text { Epeorus longimanus } & 1 & 0 & 0 & 4 \\ \text { Plecoptera (stoneflies) } & & & & 14 \\ \text { Pteronarcella badia } & 0 & 2 & 2 & 4 \\ \text { Capniidae } & 0 & 1 & 0 & 4 \\ \text { Chloroperlidae } & 0 & 1 & 0 & \\ & & & & \\ \text { Trichoptera (caddisflies) } & & & & \\ \text { Hydropsyche sp. } & 0 & 2 & 0 & 54 \\ & & & & 11 \\ \text { Diptera (true flies) } & & 10 & 1 & 46 \\ \text { Cricotopus sp. } & 4 & 0 & 0 & 4 \\ \text { Orthocladius sp } & 3 & 8 & 4 & 4 \\ \text { Parametriocnemus sp. } & 12 & 0 & 0 & 11 \\ \text { Thienemanniella sp. } & 1 & 1 & 0 & \\ \text { Thienemannimyia sp. group } & 0 & 0 & 1 & \\ \text { Tipula sp. } & 0 & 1 & 1 & 4 \\ \text { Chironomidae pupa } & 1 & & & 4 \\ \text { Coleoptera (beetles) } & & & 0 & \\ \text { Dytiscus sp. } & 1 & 0 & 1 & \\ \text { Helichus striatus } & 0 & 1 & 0 & \\ \text { Heterlimius corpulentus } & 0 & 0 & & \end{array}$

COLLEMBOLA (springtails)

Isotomurus palustris

0

1

0

4

OLIGOCHAETA (worms)

Limnodrilus sp.

Tubificidae

26

0

0

0

2

100

TOTAL

88

119

27

840 
Table 19.--species list, replicate samples, and mean density of benthic invertebrates for selected sites on Fountain and Monument Creeks--Continued

\begin{tabular}{cccc} 
Taxa & $\begin{array}{c}\text { Replicate sample, } \\
\text { number of organisms }\end{array}$ & $\begin{array}{c}\text { Mean density, } \\
\text { numbers of organisms } \\
\text { per square meter }\end{array}$ \\
\hline 07103700 FOUNTAIN CREEK NEAR COLORADO SPRINGS (SITE F4) & Sample Date: October 28, 1985
\end{tabular}

INSECTA

Ephemeroptera (mayflies)

Baetis tricaudatus

Drunella grandis grandis

Ephemerella inermis

$\begin{array}{rrrr}190 & 170 & 130 & 1,800 \\ 5 & 5 & 1 & 39 \\ 3 & 5 & 2 & 36 \\ & & & \\ 0 & 0 & 1 & 4 \\ 1 & 0 & 0 & 4 \\ 0 & 3 & 4 & \\ & & & 4 \\ & & & 65 \\ 1 & 0 & 0 & 380\end{array}$

Plecoptera (stoneflies)

Isoperla sobria

Prostoia besametsa

Chloroperlidae

Trichoptera (caddisflies)

Arctopsyche grandis

Glossosoma sp.

Hydropsyche sp.

Diptera (true flies)

Antocha sp.

Cordites sp.

Cricotopus sp.

Dicranota sp.

Eukiefferiella sp.

Pagastia sp.

Parametriocnemus sp.

Prosimulium sp.

Tipula sp.

Chironomidae pupa

1

1

$\begin{array}{lll}0 & 1 & 7\end{array}$

1

1

0

0

8

8

1

0

\section{MOLLUSCA}

Gastropoda (snails)

Physa sp.

0

1

0

4

OLIGOCHAETA (worms)

Tubificidae

11

8

11

110

TOTAL

290

220

220

2,600 
Table 19.--Species list, replicate samples, and mean density of benthic invertebrates for selected sites on Fountain and Monument Creeks--Continued

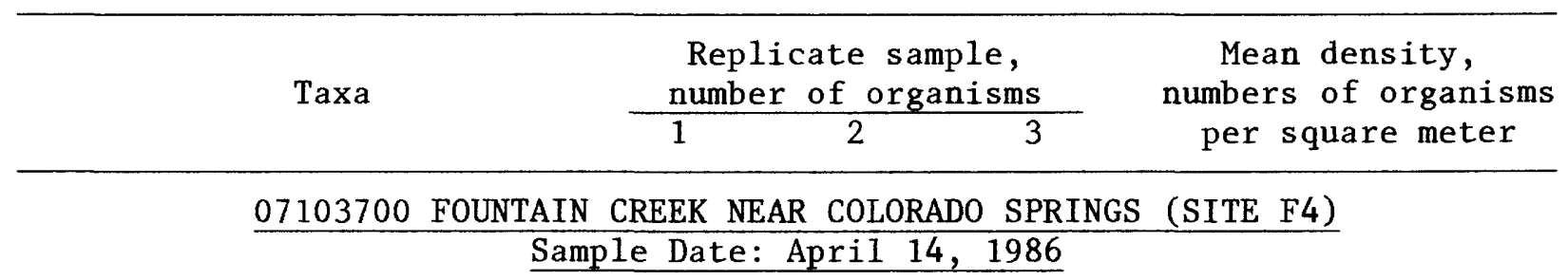

INSECTA

Ephemeroptera (mayflies)

Drunella grandis grandis
Ameletus sp.

Baetis tricaudatus

Epeorus longimanus

Ephemerella inermis

0

58

3

32

21

Plecoptera (stoneflies)

Amphinemura sp.

Isoperla sobria

Taenionema nigripenne

Chloroperlidae

Trichoptera (caddisflies)

Hydropsyche sp.

Lepidostoma sp.

Rhyacophila acropedes

Rhyacophila hyalinata

Diptera (true flies)

Antocha sp.

Chelifera sp.

Cricotopus sp.

Diamesa sp.

Dicranota sp.

Eukiefferiella sp.

Micropsectra sp.

Orthocladius sp.

Parametriocnemus sp.

Thienemanniella sp.

Thienemannimyia sp. group

Tipula sp.

Chironomidae pupa

OLIGOCHAETA (worms)

Tubificidae

96

820

1

1

1

1

12

0

260

190

0

28

0

48

20

0

0

0

20

TOTAL
Glossosoma sp.

8

16

92

57

830

54

130

180

$\begin{array}{rr}1 & 0 \\ 22 & 84 \\ 0 & 0 \\ 5 & 4 \\ 0 & 4\end{array}$

0
44
4
8
0

4
540
14
61
14

0

0

310

170

0

24

4

28

16

4

4
4

1

0

8

72

14

200

88

2,800

1,600

14

220

14

430

160

14

14

4

86

76

64

850

830

620

8,200 
Table 19.--species 1ist, replicate samples, and mean density of benthic invertebrates for selected sites on Fountain and Monument Creeks--Continued

\begin{tabular}{cccc}
\hline Taxa & $\begin{array}{c}\text { Replicate sample, } \\
\text { number of organisms }\end{array}$ & $\begin{array}{c}\text { Mean density, } \\
\text { numbers of organisms } \\
\text { per square meter }\end{array}$ \\
\hline 07103700 FOUNTAIN CREEK NEAR COLORADO SPRINGS (SITE F4) \\
\hline Sample Date: July 10, 1986
\end{tabular}

INSECTA

Ephemeroptera (mayflies)

Baetis bicaudatus

Baetis tricaudatus

Cinygmula sp.

Epeorus longimanus

Ephemerella inermis

$\begin{array}{rrrr}88 & 12 & 14 & 410 \\ 64 & 40 & 86 & 680 \\ 4 & 0 & 0 & 14 \\ 0 & 0 & 2 & 7 \\ 0 & 0 & 2 & 7\end{array}$

Plecoptera (stoneflies)

Pteronarcella badia

Chloroperlidae

0

$\begin{array}{llll}4 & 0 & 0 & 14\end{array}$

Trichoptera (caddisflies)

Cheumatopsyche sp.

Hydropsyche sp.

Rhyacophila sp.

0

20

4

Diptera (true flies)

Chelifera sp.

Chironomus sp.

Corynoneura sp.

Cricotopus sp.

Diamesa sp.

Eukiefferiella sp.

Micropsectra sp.

Parametriocnemus sp.

Prosimulium sp.

Simulium vittatum complex

Chironomidae pupa

$\begin{array}{rrr}4 & 0 & \\ 0 & 0 & \\ 0 & 4 & \\ 24 & 16 & 10 \\ 4 & 0 & \\ 4 & 0 \\ 4 & 0 \\ 8 & 0 \\ 20 & 0 \\ 0 & 0 \\ 4 & 0\end{array}$

HYDRACARINA (water mites)

12

0

0

22

86

$\begin{array}{ll}4 & 86 \\ 0 & 14\end{array}$

OLIGOCHAETA (worms)

Eiseniella tetraedra

Tubificidae

8

180

4

0

43

14

$2 \quad 7$

$0 \quad 14$

$10 \quad 180$

$\begin{array}{ll}0 & 14\end{array}$

$0 \quad 14$

222

$0 \quad 29$

279

27

222

TOTAL

460

320

230

1,800

3,500 
Table 19.--species list, replicate samples, and mean density of benthic invertebrates for selected sites on Fountain and Monument Creeks--Continued

\begin{tabular}{cccc} 
Taxa & $\begin{array}{c}\text { Replicate sample, } \\
\text { number of organisms }\end{array}$ & $\begin{array}{c}\text { Mean density, } \\
\text { numbers of organisms } \\
\text { per square meter }\end{array}$ \\
\hline 07103700 FOUNTAIN CREEK NEAR COLORADO SPRINGS (SITE F4) & SAMPLE DATE : AUGUST 25, 1986
\end{tabular}

INSECTA

\begin{tabular}{|c|c|c|c|c|}
\hline \multicolumn{5}{|l|}{ Ephemeroptera (mayflies) } \\
\hline Baetis bicaudatus & 0 & 0 & 5 & 18 \\
\hline Baetis tricaudatus & 15 & 13 & 18 & 160 \\
\hline \multicolumn{5}{|l|}{ Diptera (true flies) } \\
\hline Prodiamesa sp. & 12 & 6 & 3 & 75 \\
\hline Thienemannimyia sp. group & 2 & 0 & 1 & 11 \\
\hline Chironomidae pupa & 1 & 0 & 0 & 4 \\
\hline
\end{tabular}

OLIGOCHAETA (worms)

Eiseniella tetraedra

Limnodrilus sp.

1

0

0
7

0

4

TOTAL

31

26

30

310 
Table 19.--Species list, replicate samples, and mean density of benthic invertebrates for selected sites on Fountain and Monument Creeks--Continued

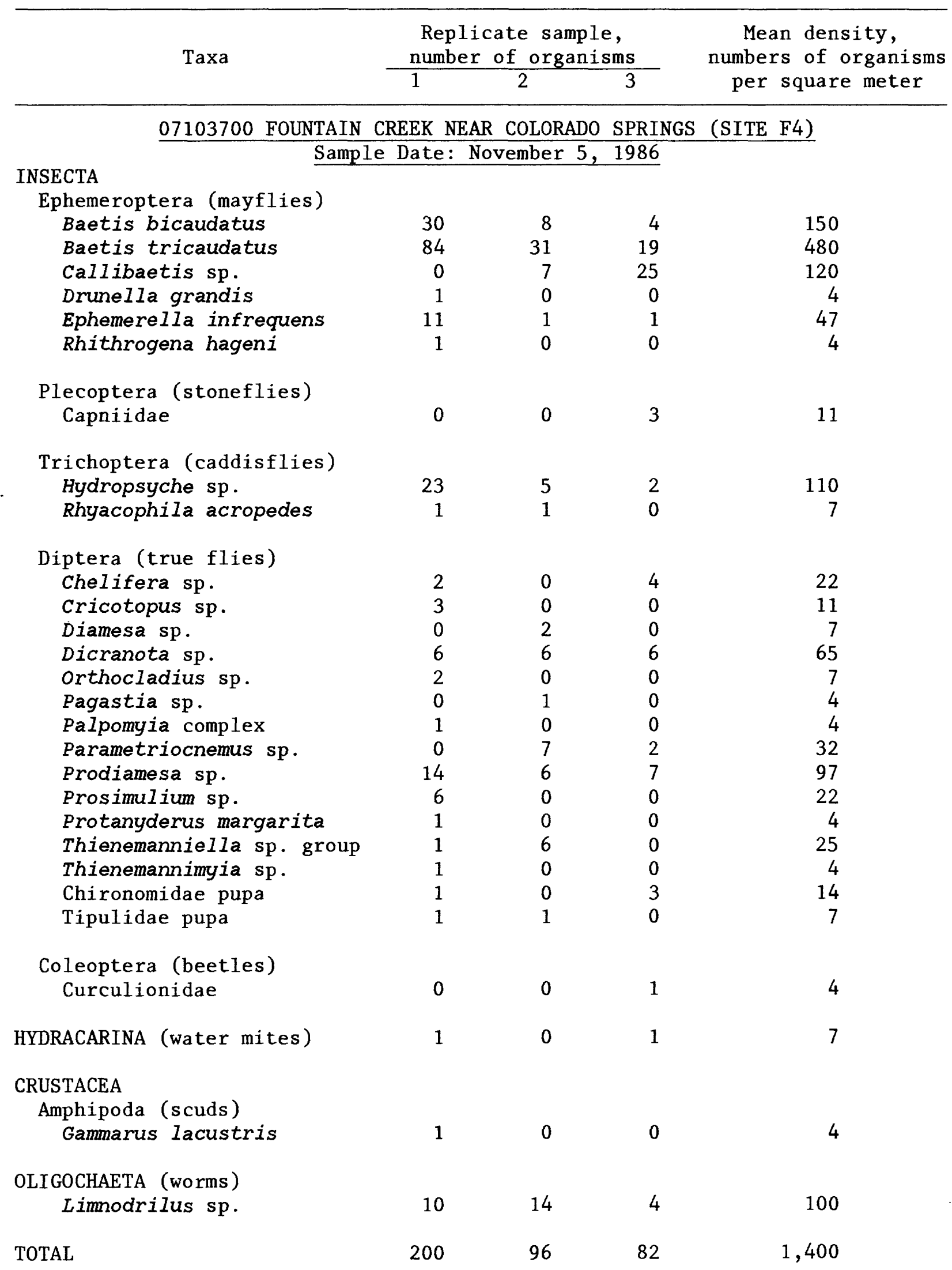


Table 19.--Species list, replicate samples, and mean density of benthic invertebrates for selected sites on Fountain and Monument Creeks--Continued

\begin{tabular}{|c|c|c|c|c|}
\hline \multirow[t]{2}{*}{ Taxa } & \multicolumn{3}{|c|}{$\begin{array}{l}\text { Replicate sample, } \\
\text { number of organisms }\end{array}$} & \multirow{2}{*}{$\begin{array}{c}\text { Mean density, } \\
\text { numbers of organisms } \\
\text { per square meter }\end{array}$} \\
\hline & 1 & 2 & 3 & \\
\hline \multicolumn{5}{|c|}{07103700 FOUNTAIN CREEK NEAR COLORADO SPRINGS (SITE F4) } \\
\hline \multicolumn{5}{|l|}{ INSECTA } \\
\hline \multicolumn{5}{|l|}{ Ephemeroptera (mayflies) } \\
\hline Ameletus sp. & 58 & 9 & 19 & 310 \\
\hline Baetis bicaudatus & 1 & 1 & 0 & 7 \\
\hline \multicolumn{5}{|l|}{ Plecoptera (stoneflies) } \\
\hline Pteronarcella sp. & 0 & 0 & 1 & 4 \\
\hline Chloroperlidae & 0 & 0 & 1 & 4 \\
\hline \multicolumn{5}{|l|}{ Diptera (true flies) } \\
\hline Chelifera sp. & 0 & 1 & 0 & 4 \\
\hline Cricotopus sp. & 6 & 0 & 5 & 39 \\
\hline Diamesa sp. & 9 & 0 & 13 & 79 \\
\hline Dicranota sp. & 0 & 0 & 1 & 4 \\
\hline Micropsectra sp. & 1 & 0 & 0 & 4 \\
\hline Molophilus sp. & 0 & 0 & 1 & 4 \\
\hline Orthocladius sp. & 27 & 9 & 40 & 270 \\
\hline Parametriocnemus sp. & 25 & 14 & 36 & 270 \\
\hline Prodiamesa sp. & 27 & 1 & 19 & 170 \\
\hline Thienemanniella sp. & 4 & 2 & 0 & 21 \\
\hline Tipula sp. & 0 & 0 & 1 & 4 \\
\hline Chironomidae pupa & 2 & 3 & 4 & 32 \\
\hline COLLEMBOLA (springtails) & 0 & 0 & 1 & 4 \\
\hline \multicolumn{5}{|l|}{ OLIGOCHAETA (worms) } \\
\hline Eiseniella tetraedra & 2 & 0 & 2 & 14 \\
\hline Limnodrilus $\mathrm{sp}$ & 12 & 20 & 3 & 130 \\
\hline TOTAL & 170 & 60 & 150 & 1,400 \\
\hline
\end{tabular}


Table 19.--Species list, replicate samples, and mean density of benthic invertebrates for selected sites on Fountain and Monument Creeks--Continued

\begin{tabular}{cccc}
\hline Taxa & $\begin{array}{c}\text { Replicate sample, } \\
\text { number of organisms }\end{array}$ & $\begin{array}{c}\text { Mean density, } \\
\text { numbers of organisms } \\
\text { per square meter }\end{array}$ \\
\hline$\frac{1}{2} \quad 2 \quad 303700$ FOUNTAIN CREEK NEAR COLORADO SPRINGS (SITE F4) \\
\hline Sample Date: July 15, 1987
\end{tabular}

\section{INSECTA}

Ephemeroptera (mayflies)

Baetis bicaudatus

Baetis tricaudatus

Cinygmula sp.

Epeorus longimanus

Ephemerella sp.

$\begin{array}{rrrr}47 & 9 & 32 & 320 \\ 18 & 8 & 6 & 120 \\ 0 & 1 & 2 & 11 \\ 3 & 0 & 0 & 11 \\ 1 & 0 & 0 & 4\end{array}$

Plecoptera (stoneflies)

Pteronarcella badia

Chloroperlidae

1

0

0

0

7

Diptera (true flies)

Cricotopus sp.

Cryptochironomus sp.

Hexatoma sp.

Orthocladius sp.

Parametriocnemus sp.

Simulium sp.

Thienemanniella sp.

Thienemannimyia sp. group

Chironomidae pupa

$\begin{array}{rrr}2 & 2 \\ 0 & 2 & \\ 1 & 0 & \\ 3 & 2 & \\ 21 & 11 & 21 \\ 6 & 0 & \\ 1 & 1 \\ 2 & 0 \\ 1 & 1\end{array}$

$2 \quad 21$

$0 \quad 7$

04

$6 \quad 39$

$21 \quad 190$

229

$0 \quad 7$

111

11

HYDRACARINA (water mites)

1

$0 \quad 0$

4

OLIGOCHAETA (worms)

Limnodrilus sp.

33

54

40

460

HIRUDINEA (leeches)

Erpobdella punctata

1

0

0

4

TOTAL

140

91

110

1,300 
Table 19.--Species list, replicate samples, and mean density of benthic invertebrates for selected sites on Fountain and Monument Creeks--Continued

\begin{tabular}{cccc} 
Taxa & \multicolumn{2}{c}{$\begin{array}{c}\text { Replicate sample, } \\
\text { number of organisms }\end{array}$} & $\begin{array}{c}\text { Mean density, } \\
\text { numbers of organisms } \\
\text { per square meter }\end{array}$ \\
\hline $\begin{array}{l}\text { 07103700 FOUNTAIN CREEK NEAR COLORADO SPRINGS } \\
\text { Sample Date: August 26, 1987 }\end{array}$
\end{tabular}

INSECTA

Ephemeroptera (mayflies)

\begin{abstract}
Baetis bicaudatus
Baetis tricaudatus

Drunella grandis
\end{abstract}

Plecoptera (stoneflies)

Pteronarcella badia

Chloroperlidae

Trichoptera (caddisflies)

Hydropsyche sp.
41

48

0

1

0

0

Lepidoptera (aquatic caterpillars) Simyra sp.

Diptera (true flies)

Cricotopus sp.

Eukiefferiella sp.

Parametriocnemus sp.

Simulium sp.

Thienemannimyia sp. group

Empididae pupa
0

$\begin{array}{rr}3 & 0 \\ 7 & 2 \\ 15 & 10 \\ 0 & 26 \\ 3 & 0 \\ 0 & 2\end{array}$

0

118

1

10

130
36
0

OLIGOCHAETA (worms)

Limnodrilus sp.

TOTAL
14

2

16

0

\section{7}

24

1

1

1

57

11

65

\section{4}

18

40

110

100

11

7

36

0

68

1,600 
Table 19.--species list, replicate samples, and mean density of benthic invertebrates for selected sites on Fountain and Monument Creeks--Continued

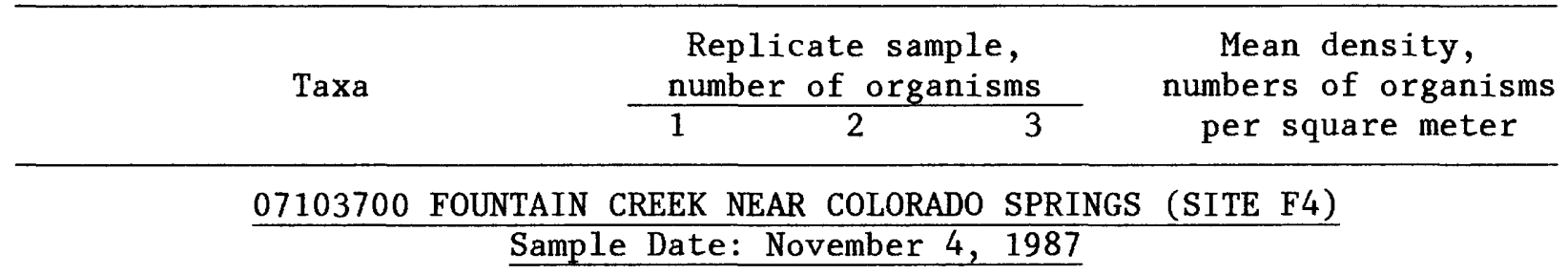

INSECTA

Ephemeroptera (mayflies)

Baetis bicaudatus

Baetis tricaudatus

Drunella grandis grandis

Ephemerella infrequens

5

$9-31$

$31 \quad 3$

150

$59 \quad 170$

2

2

52

4

1,000

2

1

29

11

Plecoptera (stoneflies)

Alloperla sp.

Hesperoperla pacifica

Pteronarcella badia

Capniidae

0

$$
\begin{array}{r}
7 \\
4 \\
18
\end{array}
$$

18

Trichoptera (caddisflies)

Arctopsyche grandis

Glossoma sp.

Hydropsyche sp.

Diptera (true flies)

Chelifera sp.

Dicranota sp.

Orthocladius sp.

Parametriocnemus sp.

Prosimulium sp.

Thienemanniella sp.

Thienemannimyia sp. group

Tipula sp.

$0 \quad 0$

1

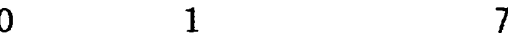

$\begin{array}{lll}0 & 6 & 180\end{array}$

Coleoptera (beetles)

optioservus divergens

\section{OLIGOCHAETA (worms)}

Eiseniella tetraedra

Limnodrilus sp.

TOTAL

sp.

1

12

160

250

$\begin{array}{lr}0 & 4 \\ 2 & 36 \\ 1 & 7 \\ 4 & 39 \\ 4 & 32 \\ 1 & 4 \\ 1 & 29 \\ 1 & 14\end{array}$

14

7
140

140

1,700 
Table 19.--Species 1ist, replicate samples, and mean density of benthic invertebrates for selected sites on Fountain and Monument Creeks--Continued

\begin{tabular}{cccc} 
Taxa & $\begin{array}{c}\text { Replicate sample, } \\
\text { number of organisms }\end{array}$ & $\begin{array}{c}\text { Mean density, } \\
\text { numbers of organisms } \\
\text { per square meter }\end{array}$ \\
\hline $\begin{array}{l}\text { 07103700 FOUNTAIN CREEK NEAR COLORADO SPRINGS (SITE F4) } \\
\text { Sample Date: April 25, 1988 }\end{array}$
\end{tabular}

INSECTA

Ephemeroptera (mayflies)

Baetis tricaudatus

Callibaetis sp.

Drunella grandis

0

$4 \quad 0$

$0 \quad 1$

$2 \quad 7$

7

4

Plecoptera (stoneflies)

Chloroperlidae

2

1

11

Trichoptera (caddisflies)

Hydropsyche sp.

0

2

7

Diptera (true flies)

Boreoheptogyia sp.

Diamesa sp.

Dicranota sp.

Eukiefferiella sp.

Micropsectra sp.

Orthocladius sp.

Pagastia sp.

Parametriocnemus sp.

Thienemannimyia sp. group

Chironomidae pupa

$\begin{array}{rrr}2 & 0 & \\ 6 & 3 & 14 \\ 2 & 0 & 2 \\ 2 & 2 & 0 \\ 2 & 3 & 2 \\ 10 & 1 & 8 \\ 6 & 10 & 8 \\ 18 & 3 & 2 \\ 0 & 2 & 0 \\ 10 & 2 & 6\end{array}$

COLLEMBOLA (springtails)

Isotomurus palustris

6

0

2

29

CRUSTACEA

Amphipoda (sideswimmers)

Hyalella azteca

0

1

0

4

OLIGOCHAETA (worms)

Eiseniella tetraedra

2

Limnodrilus sp.

16

0

7

TOTAL

88

31

54

630 
Table 19.--Species 1ist, replicate samples, and mean density of benthic invertebrates for selected sites on Fountain and Monument Creeks--Continued

\begin{tabular}{|c|c|c|}
\hline \multirow[t]{2}{*}{ Taxa } & $\begin{array}{l}\text { Replicate } \\
\text { number of }\end{array}$ & \multirow{2}{*}{$\begin{array}{l}\text { Mean density, } \\
\text { numbers of organisms } \\
\text { per square meter }\end{array}$} \\
\hline & $\begin{array}{ll}1 & 2\end{array}$ & \\
\hline
\end{tabular}

07103700 FOUNTAIN CREEK NEAR COLORADO SPRINGS (SITE F4)

Sample Date: June 30, 1988

INSECTA

Ephemeroptera (mayflies)

Baetis tricaudatus

6

40

0

160

Plecoptera (stoneflies)

Chloroperlidae

1

0

0

4

Trichoptera (caddisflies)

Hydropsyche sp.

1

8

32

Diptera (true flies)

Chelifera sp.

Orthocladius sp.

Pagastia sp.

Parametriocnemus sp.

Simulium sp.

Thienemannimyia sp. group

Chironomidae pupa

1

0

0

3

1

0

0

Coleoptera (beetles)

Helophorus sp.

0

8

0

(1)

0

4

4
0

0

4

4

0

\section{0}

0

2

10

2

0

4

4

14

7

47

25

14

14

OLIGOCHAETA (worms)

Eiseniella tetraedra

Limodrilus sp.

0

8

29

2

12

0

93

TOTAL

15

88

36

490 
Table 19.--Species list, replicate samples, and mean density of benthic invertebrates for selected sites on Fountain and Monument Creeks--Continued

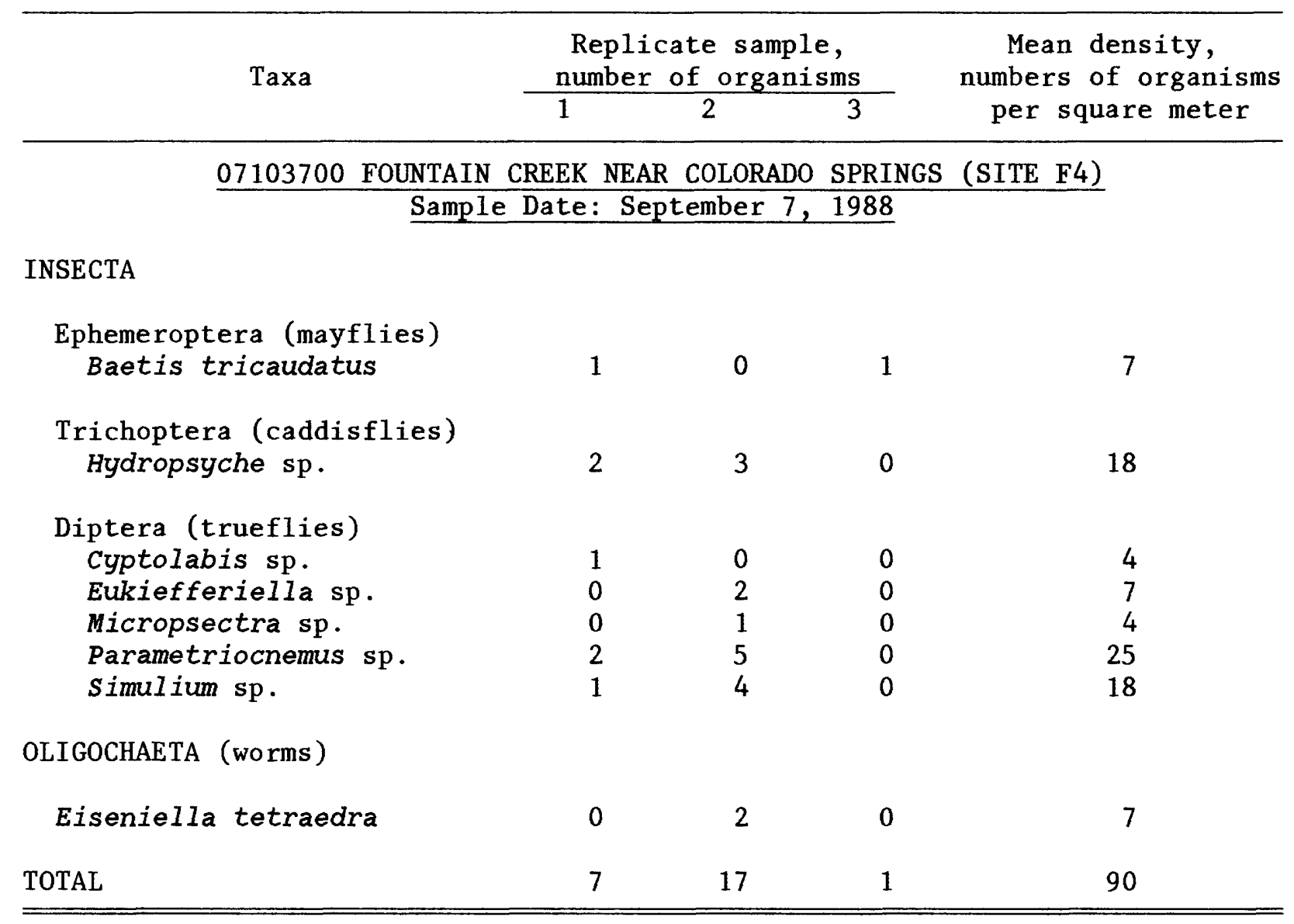


Table 19.--Species list, replicate samples, and mean density of benthic invertebrates for selected sites on Fountain and Monument Creeks--Continued

Replicate sample,

Taxa number of organisms

1

Mean density, numbers of organisms per square meter

07105500 FOUNTAIN CREEK AT COLORADO SPRINGS (SITE F8)

Sample Date: April 16, 1985

INSECTA

Ephemeroptera (mayflies)

Baetis tricaudatus

Ephemerella inermis

$1 \quad 0 \quad 2$

2
1

11

1

0

1

7

Plecoptera (stonefies)

Isogenoides zionensis

Chloroperlidae

0

0

0

$$
4
$$

$\begin{array}{lll}1 & 5 & 22\end{array}$

Diptera (true flies)

Cricotopus sp.

Diamesa sp.

Orthocladius sp.

Palpomyia complex

Parametriocnemus sp.

Thienemanniella sp.

Chironomidae pupa

$\begin{array}{rrrr}0 & 0 & 8 & 29 \\ 3 & 5 & 24 & 120 \\ 4 & 2 & 29 & 130 \\ 1 & 0 & 0 & 4 \\ 4 & 0 & 6 & 36 \\ 0 & 1 & 1 & 7 \\ 0 & 1 & 0 & 4\end{array}$

OLIGOCHAETA (worms)

Limodrilus sp.

10

14

3

97

TOTAL

25

24

79

470 
Table 19.--Species list, replicate samples, and mean density of benthic invertebrates for selected sites on Fountain and Monument Creeks--Continued

\begin{tabular}{|c|c|c|c|c|}
\hline \multirow[t]{2}{*}{ Taxa } & \multicolumn{3}{|c|}{$\begin{array}{l}\text { Replicate sample, } \\
\text { number of organisms }\end{array}$} & \multirow{2}{*}{$\begin{array}{l}\text { Mean density, } \\
\text { numbers of organisms } \\
\text { per square meter }\end{array}$} \\
\hline & 1 & 2 & 3 & \\
\hline \multirow{2}{*}{\multicolumn{5}{|c|}{$\frac{07105500 \text { FOUNTAIN CREEK AT COLORADO SPRINGS (SITE F8) }}{\text { Sample Date: July } 11,1985}$}} \\
\hline & & & & \\
\hline \multicolumn{5}{|l|}{ INSECTA } \\
\hline \multicolumn{5}{|l|}{ Ephemeroptera (mayflies) } \\
\hline Ameletus cooki & 0 & 0 & 3 & 11 \\
\hline Baetis tricaudatus & 22 & 7 & 71 & 360 \\
\hline Epeorus longimanus & 2 & 2 & 4 & 29 \\
\hline Tricorythodes minutus & 0 & 4 & 8 & 43 \\
\hline \multicolumn{5}{|l|}{ Plecoptera (stoneflies) } \\
\hline Pteronarcella badia & 0 & 1 & 0 & 4 \\
\hline Chloroperlidae & 0 & 0 & 2 & 7 \\
\hline \multicolumn{5}{|l|}{ Trichoptera (caddisflies) } \\
\hline Hydropsyche sp. & 1 & 0 & 3 & 14 \\
\hline ochrotrichia sp. & 0 & 0 & 1 & 4 \\
\hline \multicolumn{5}{|l|}{ Diptera (true flies) } \\
\hline Chelifera sp. & 0 & 0 & 2 & 7 \\
\hline Cordites sp. & 1 & 0 & $\overline{0}$ & 4 \\
\hline Cricotopus sp. & 7 & 8 & 54 & 250 \\
\hline Dixa sp. & 0 & 0 & 1 & 4 \\
\hline Ephydra sp. & 0 & 0 & 5 & 18 \\
\hline Micropsecta sp. & 0 & 1 & 1 & 7 \\
\hline Orthocladius sp. & 34 & 24 & 140 & 720 \\
\hline Parametriocnemus sp. & 71 & 99 & 440 & 2,200 \\
\hline Phaenopsecta sp. & 0 & 1 & 0 & 4 \\
\hline Psychoda sp. & 0 & 0 & 3 & 11 \\
\hline Simulium sp. & 0 & 0 & 21 & 75 \\
\hline Thienemanniella sp. & 0 & 1 & 3 & 14 \\
\hline Thienemannimyia sp. group & 0 & 1 & 0 & 4 \\
\hline Chironomidae pupa & 4 & 5 & 29 & 140 \\
\hline Dolichopidae & 0 & 1 & 0 & 4 \\
\hline \multicolumn{5}{|l|}{ Coleoptera (beetles) } \\
\hline Agabus sp. & 0 & 0 & 1 & 4 \\
\hline \multicolumn{5}{|l|}{ COLLEMBOLA (spingtails) } \\
\hline Isotomurus palustris & 0 & 2 & 2 & 14 \\
\hline \multicolumn{5}{|l|}{ OLIGOCHAETA（worms） } \\
\hline Limnodrilus $\mathrm{sp}$ & 120 & 15 & 0 & 480 \\
\hline Lumbricidae & 1 & 0 & 0 & 4 \\
\hline TOTAL & 260 & 170 & 790 & 4,400 \\
\hline
\end{tabular}


Table 19.--species list, replicate samples, and mean density of benthic invertebrates for selected sites on Fountain and Monument Creeks--Continued

\begin{tabular}{ccccc} 
Taxa & $\begin{array}{c}\text { Replicate sample, } \\
\text { number of organisms }\end{array}$ & $\begin{array}{c}\text { Mean density, } \\
\text { numbers of organisms } \\
\text { per square meter }\end{array}$ \\
\hline 07105500 FOUNTAIN CREEK AT COLORADO SPRINGS (SITE F8) & Sample Date: August 12, 1985
\end{tabular}

INSECTA

Trichoptera (caddisflies)

Hydropsyche sp.

0

0

1

4

Lepidoptera (aquatic caterpilers)

Parargyractis sp.

0

1

0

4

Diptera (true flies)

Hexatoma sp.

Micropsectra sp.

Orthocladius sp.

Parametriocnemus sp.

Phaenopsectra sp.

Thienemanniella sp.

1

Coleoptera (beetles)

Listronotus $\mathrm{sp}$.

0

2

1

0

1

4

0

1

4

4

4

25

4

7

HYDRACARINA (water mites)

Mideopsis sp.

1

0

0

4

COLLEMBOLA (springtails)

Isotomurus palustris

1

1

0

7

OLIGOCHAETA (worms)

Limnodrilus sp.

1

8

4

47

TOTAL

7

14

12

120 
Table 19.--Species list, replicate samples, and mean density of benthic invertebrates for selected sites on Fountain and Monument Creeks--Continued

\begin{tabular}{ccc} 
Taxa & $\begin{array}{c}\text { Replicate sample, } \\
\text { number of organisms }\end{array}$ & $\begin{array}{c}\text { Mean density, } \\
\text { numbers of organisms } \\
\text { per square meter }\end{array}$ \\
\cline { 2 - 2 } & 2 & 3
\end{tabular}

07105500 FOUNTAIN CREEK AT COLORADO SPRINGS (SITE F8)

Sample Date: October 28, 1985

\section{INSECTA}

Ephemeroptera (mayflies)

Baetis tricaudatus

Tricorythodes minutus

0

0

2

1

0

0

11

Trichoptera (caddisflies)

Hydropsyche sp.

0

2

0

7

Diptera (true flies)

Cordites sp.

Eukiefferiella sp.

Micropsectra sp.

Orthocladius sp.

Pagastia sp.

Parametriocnemus sp.

Thienemannimyia sp. group

Chironomidae pupa

0

0

0

0

0

0

0

0

1

0

0

7

$1 \quad 0$

47
4

1

4

20

7

$\begin{array}{ll}7 & 19\end{array}$

93

$\begin{array}{rrr}1 & 0 & 4 \\ 1 & 4 & 18\end{array}$

Hemiptera (true bugs)

Corixidae

1

29

27

6

220

TOTAL

30

47

42

430 
Table 19.--Species list, replicate samples, and mean density of benthic invertebrates for selected sites on Fountain and Monument Creeks--Continued

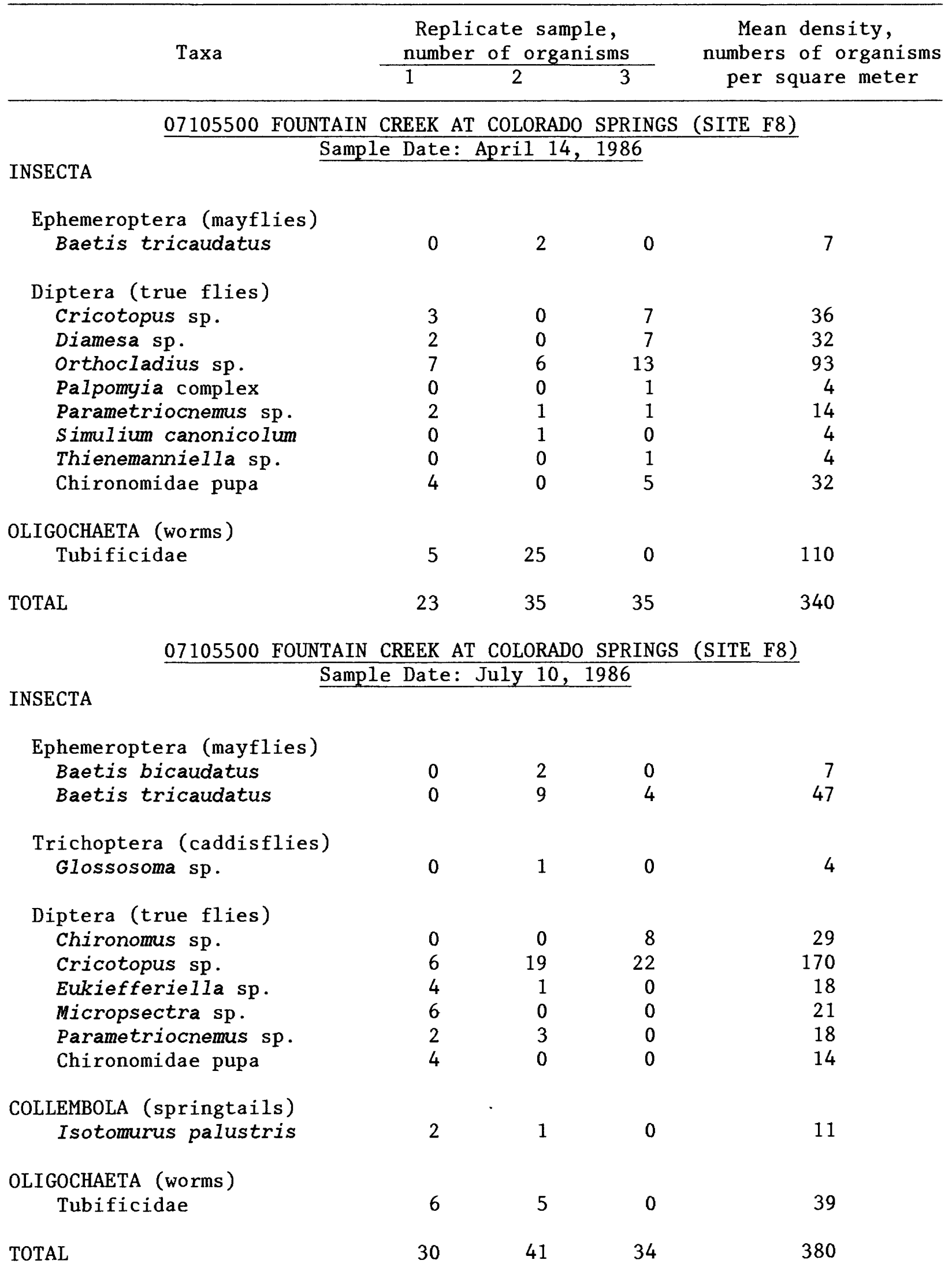


Table 19.--Species list, replicate samples, and mean density of benthic invertebrates for selected sites on Fountain and Monument Creeks--Continued

\begin{tabular}{|c|c|c|c|c|}
\hline \multirow[t]{2}{*}{ Taxa } & \multicolumn{3}{|c|}{$\begin{array}{l}\text { Replicate sample, } \\
\text { number of organisms }\end{array}$} & \multirow{2}{*}{$\begin{array}{c}\text { Mean density, } \\
\text { numbers of organisms } \\
\text { per square meter }\end{array}$} \\
\hline & 1 & 2 & 3 & \\
\hline \multicolumn{5}{|c|}{$\begin{array}{l}07105500 \text { FOUNTAIN CREEK AT COLORADO SPRINGS (SITE F8) } \\
\text { Sample Date: August } 25,1986\end{array}$} \\
\hline \multicolumn{5}{|l|}{ INSECTA } \\
\hline $\begin{array}{l}\text { Ephemeroptera (mayflies) } \\
\text { Baetis tricaudatus }\end{array}$ & 0 & 6 & 4 & 36 \\
\hline \multicolumn{5}{|l|}{ Plecoptera (stoneflies) } \\
\hline Pteronarcella badia & 0 & 0 & 1 & 4 \\
\hline $\begin{array}{l}\text { Trichoptera (caddisflies) } \\
\text { Hydropsyche sp. }\end{array}$ & 0 & 0 & 1 & 4 \\
\hline \multicolumn{5}{|l|}{ Diptera (true flies) } \\
\hline Cryptochironomus sp. & 0 & 2 & 2 & 14 \\
\hline Micropsectra sp. & 0 & 1 & 0 & 4 \\
\hline Parametriocnemus sp. & 2 & 0 & 0 & 7 \\
\hline Prodiamesa sp. & 2 & 15 & 9 & 93 \\
\hline Simulium sp. & 0 & 1 & 0 & 4 \\
\hline Thienemannimyia sp. group & 1 & 0 & 0 & 4 \\
\hline Chironomidae pupa & 0 & 7 & 4 & 39 \\
\hline \multicolumn{5}{|l|}{ OLIGOCHAETA (wo rms) } \\
\hline Eiseniella tetraedra & 0 & 0 & 1 & 4 \\
\hline Limnodrilus sp. & 7 & 6 & 0 & 47 \\
\hline TOTAL & 12 & 38 & 22 & 260 \\
\hline
\end{tabular}


Table 19.--Species list, replicate samples, and mean density of benthic invertebrates for selected sites on Fountain and Monument Creeks--Continued

\begin{tabular}{ccccc}
\hline Taxa & $\begin{array}{c}\text { Replicate sample, } \\
\text { number of organisms }\end{array}$ & $\begin{array}{c}\text { Mean density, } \\
\text { numbers of organisms } \\
\text { per square meter }\end{array}$ \\
\cline { 2 - 3 } & 1 & 2 & 3 & per squand
\end{tabular}

Sample Date: November 5, 1986

INSECTA

Ephemeroptera (mayflies)
Baetis tricaudatus
Tricorythodes minutus

Diptera (true flies)

Chelifera sp.

Diamesa sp.

Euparyphus sp.

Micropsectra sp.

Orthocladius sp.

Palpomyia complex

Parametriocnemus sp.

Prodiamesa sp.

Prosimilium sp.

Thienemannymia sp. group

Chironomidae pupa
0

0

0

0

0

0

0

0

5

0

0

0

0

TURBELLARIA (flat worms)

Dugesia sp.

TOTAL
Tubificidae

OLIGOCHAETA (wo rms)

Limodrilus sp.
120

0

43

0

0

120
1

1

\section{2}

2

1

1

5

1

10

70

3

1

2

(SITE F8)

mbers of organisms 
Table 19.--species list, replicate samples, and mean density of benthic invertebrates for selected sites on Fountain and Monument Creeks--Continued

Replicate sample,

Taxa number of organisms
Mean density, numbers of organisms per square meter

\section{FOUNTAIN CREEK AT COLORADO SPRINGS (SITE F8)}

\section{Sample Date: April 27, 1987}

\section{INSECTA}

Ephemeroptera (mayflies)

Ameletus sp.

Baetis tricaudatus

$\begin{array}{lll}6 & 7 & 1\end{array}$

50

0

1

4

Plecoptera (stoneflies)

Pteronarcella sp.

0

0

1

Diptera (true flies)

Chryptochironomus sp.

Cricotopus sp.

Diamesa sp.

Limnophora sp.

Micropsectra sp.

Orthocladius sp.

Palpomyia complex

Parametriocnemus sp.

Phaenopsectra sp.

Prodiamesa sp.

Chironomidae pupa

Coleoptera (beetles)

Curculionidae

0

0

1

25

$\begin{array}{lll}0 & 1 & 25 \\ 0 & 2 & 11\end{array}$

1

29

0

7

0

4

1

0

4

$7 \quad 30$

150

2

7

$6 \quad 110$

440

1

4

0

11

39

14

OLIGOCHAETA (worms)

Limnodrilus sp.

60

74

130

950

TOTAL

87

100

300

1,700 
Table 19.--Species list, replicate samples, and mean density of benthic invertebrates for selected sites on Fountain and Monument Creeks--Continued

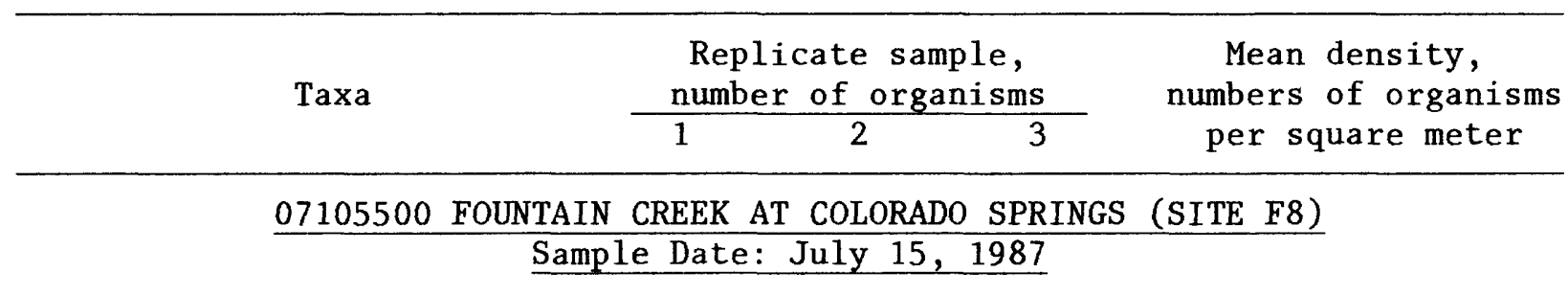

INSECTA

\begin{tabular}{|c|c|c|c|c|}
\hline Ephemeroptera (mayflies) & & & & \\
\hline Baetis bicaudatus & 1 & 6 & 2 & 32 \\
\hline Baetis tricaudatus & 2 & 0 & 3 & 18 \\
\hline Ephemerella sp. & 0 & 0 & 1 & 4 \\
\hline Tricorythodes minutus & 1 & 6 & 4 & 39 \\
\hline Plecoptera (stoneflies) & & & & \\
\hline Chloroperlidae & 1 & 0 & 0 & 4 \\
\hline Trichoptera (caddisflies & & & & \\
\hline Hydropsyche sp. & 1 & 0 & 1 & 7 \\
\hline Diptera (true flies) & & & & \\
\hline Cricotopus sp. & 1 & 1 & 2 & 14 \\
\hline Cryptochironomus sp. & 3 & 0 & 0 & 11 \\
\hline Limnophora sp. & 1 & 1 & 2 & 14 \\
\hline Orthocladius sp. & 6 & 2 & 0 & 29 \\
\hline Palpomyia complex & 0 & 1 & 0 & 4 \\
\hline Parametriocnemus sp. & 51 & 14 & 41 & 380 \\
\hline Prosimulium sp. & 0 & 0 & 1 & 4 \\
\hline Simulium sp. & 2 & 1 & 4 & 25 \\
\hline Thienemanniella sp. & 1 & 3 & 1 & 18 \\
\hline Chironomidae pupa & 5 & 2 & 2 & 32 \\
\hline YDRACARINA (water mites) & 0 & 0 & 1 & 4 \\
\hline LIGOCHAETA (worms) & & & & \\
\hline Limmodrilus sp. & 7 & 20 & 7 & 120 \\
\hline OTAL & 83 & 57 & 72 & 760 \\
\hline
\end{tabular}


Table 19.--Species list, replicate samples, and mean density of benthic invertebrates for selected sites on Fountain and Monument Creeks--Continued

\begin{tabular}{llccc}
\hline Taxa & $\begin{array}{c}\text { Replicate sample, } \\
\text { number of organisms }\end{array}$ & $\begin{array}{c}\text { Mean density, } \\
\text { numbers of organisms } \\
\text { per square meter }\end{array}$ \\
\cline { 2 - 3 } & 07105500 FOUNTAIN CREEK AT COLORADO SPRINGS (SITE F8) \\
\hline Sample Date: September 1, 1987
\end{tabular}

INSECTA

Ephemeroptera (mayflies)

Baetis bicaudatus

Baetis tricaudatus

Tricorythodes sp.

3

2

0

Plecoptera (stoneflies)

Pteronarcella badia

Diptera (true flies)

Cryptochironomus sp.

Dixella sp.

Eukiefferiella sp.

Parametriocnemus sp.

Thienemanniella sp.

Chironomidae pupa

OLIGOCHAETA (worms)

Limodrilus sp.

TOTAL
5

42

0

3
1
1
19
1
7

7

32

18
22

14

11

4

57

4

4

120

4

43

50

330 
Table 19.--Species list, replicate samples, and mean density of benthic invertebrates for selected sites on Fountain and Monument Creeks--Continued

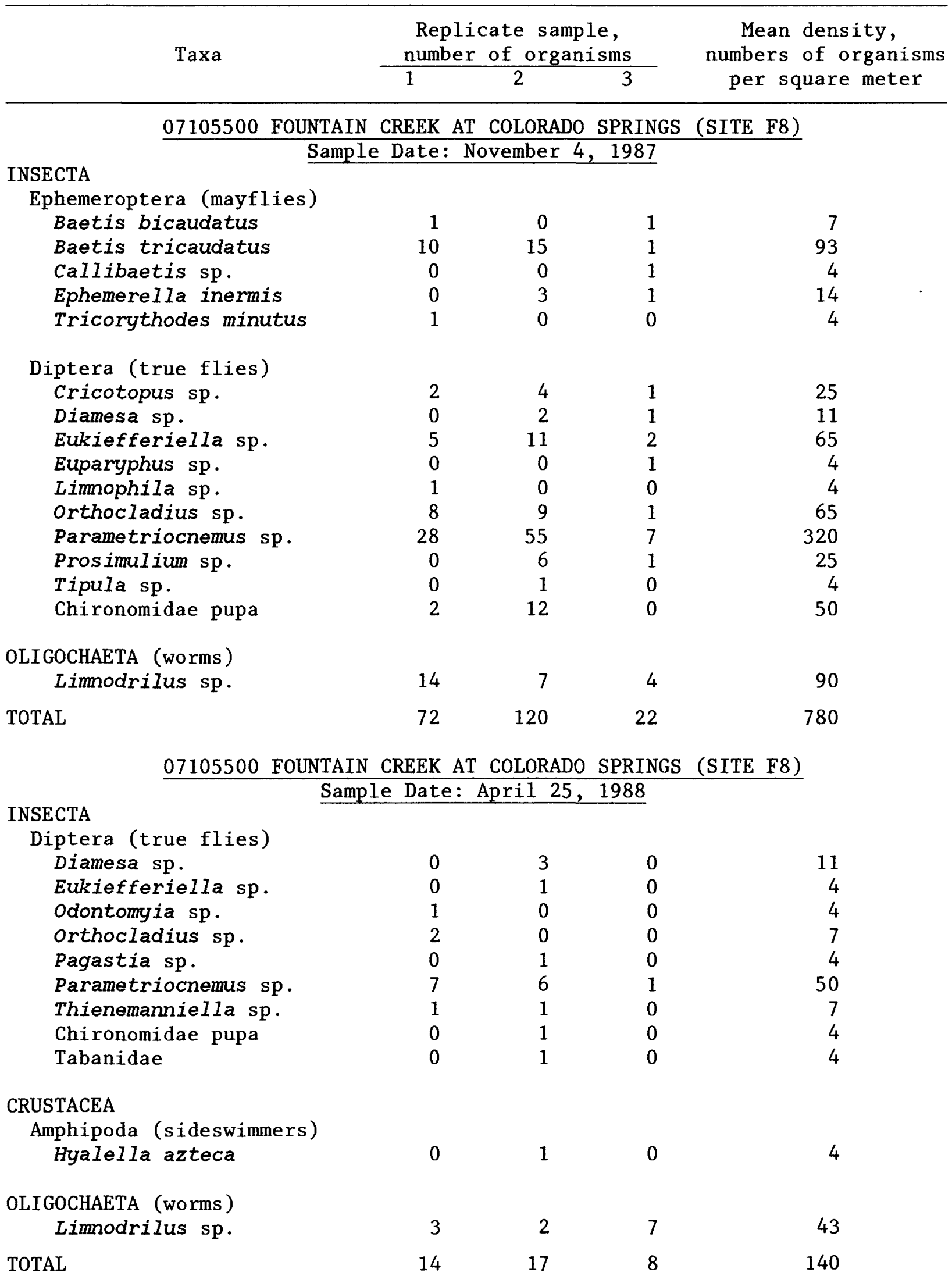


Table 19.--Species list, replicate samples, and mean density of benthic invertebrates for selected sites on Fountain and Monument Creeks--Continued

\begin{tabular}{|c|c|c|c|c|}
\hline \multirow[t]{2}{*}{ Taxa } & \multicolumn{3}{|c|}{$\begin{array}{l}\text { Replicate sample, } \\
\text { number of organisms }\end{array}$} & \multirow{2}{*}{$\begin{array}{l}\text { Mean density, } \\
\text { numbers of organisms } \\
\text { per square meter }\end{array}$} \\
\hline & 1 & 2 & 3 & \\
\hline \multicolumn{5}{|c|}{07105500 FOUNTAIN CREEK AT COLORADO SPRINGS (SITE F8) } \\
\hline Sampl & Le Date & : June 30 & 1988 & \\
\hline \multicolumn{5}{|c|}{ 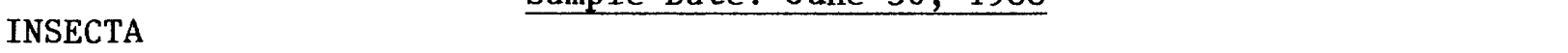 } \\
\hline \multicolumn{5}{|l|}{ Ephemeroptera (mayflies) } \\
\hline Baetis tricaudatus & 0 & 2 & 1 & 11 \\
\hline \multicolumn{5}{|l|}{ Plecoptera (stoneflies) } \\
\hline Chloroperlidae & 0 & 2 & 0 & 7 \\
\hline \multicolumn{5}{|l|}{ Trichoptera (caddisflies) } \\
\hline Hydropsyche sp. & 0 & 0 & 1 & 4 \\
\hline \multicolumn{5}{|l|}{ Diptera (true flies) } \\
\hline Cricotopus sp. & 0 & 2 & 0 & 7 \\
\hline Orthocladius sp. & 1 & 0 & 0 & 4 \\
\hline Parametriocnemus sp. & 1 & 4 & 2 & 25 \\
\hline \multicolumn{5}{|l|}{ Coleoptera (beetles) } \\
\hline Helophorus sp. & 2 & 0 & 0 & 7 \\
\hline \multicolumn{5}{|l|}{ COLLEMBOLA (springtails) } \\
\hline Isotomurus palustris & 1 & 0 & 0 & 4 \\
\hline \multicolumn{5}{|l|}{ OLIGOCHAETA (worms) } \\
\hline Eiseniella tetraedra & 0 & 0 & 1 & 4 \\
\hline Limnodrilus sp. & 4 & 6 & 3 & 47 \\
\hline TOTAL & 9 & 16 & 8 & 120 \\
\hline \multirow{3}{*}{\multicolumn{5}{|c|}{$\begin{array}{ll} & 07105500 \text { FOUNTAIN CREEK AT COLORADO SPRINGS } \\
\text { INSECTA } & \text { Sample Date: September 7, 1988 }\end{array}$}} \\
\hline & & & & \\
\hline & & & & \\
\hline \multicolumn{5}{|c|}{$\begin{array}{l}\text { INSECTA } \\
\text { Ephemeroptera (mayflies) }\end{array}$} \\
\hline Baetis bicaudatus & 17 & 1 & 1 & 68 \\
\hline \multicolumn{5}{|l|}{ Diptera (true flies) } \\
\hline Eukiefferiella sp. & 6 & 0 & 1 & 25 \\
\hline Othocladius sp. & 5 & 1 & 0 & 22 \\
\hline Parametriocnemus sp. & 83 & 16 & 30 & 460 \\
\hline Phaenopsectra sp. & 6 & 1 & 3 & 36 \\
\hline Simulium sp. & 3 & 0 & 0 & 11 \\
\hline Thienemannimyia sp. group & 1 & 0 & 0 & 4 \\
\hline Chironomidae pupa & 2 & 0 & 8 & 36 \\
\hline \multicolumn{5}{|l|}{ OLGOCHAETA (worms) } \\
\hline Tubificidae & 3 & 0 & 1 & 14 \\
\hline TOTAL & 130 & 19 & 44 & 680 \\
\hline
\end{tabular}


Table 19.--Species list, replicate samples, and mean density of benthic invertebrates for selected sites on Fountain and Monument Creeks--Continued

Taxa

Replicate sample, number of organisms

1
Mean density, numbers of organisms per square meter

07105800 FOUNTAIN CREEK AT SECURITY (SITE F13)

Sample Date: April 16, 1985

INSECTA

Plecoptera (stoneflies)

Chloroperlidae

1

0

4

Diptera (true flies)

Cricotopus sp.

Diamesa sp.

Nemotelus sp.

Parametriocnemus sp.

Phaenopsectra sp.

Thienemanniella sp.

Chironomidae pupa

$\begin{array}{rrrr}1 & 1 & 0 & 7 \\ 0 & 0 & 2 & 7 \\ 4 & 4 & 0 & 29 \\ 2 & 1 & 0 & 11 \\ 0 & 0 & 2 & 7 \\ 0 & 0 & 1 & 4 \\ 5 & 1 & 1 & 25\end{array}$

OLIGOCHAETA (worms)

Limodrilus sp.

18

13

21

190

TOTAL

31

20

27

280 
Table 19.--Species list, replicate samples, and mean density of benthic invertebrates for selected sites on Fountain and Monument Creeks--Continued

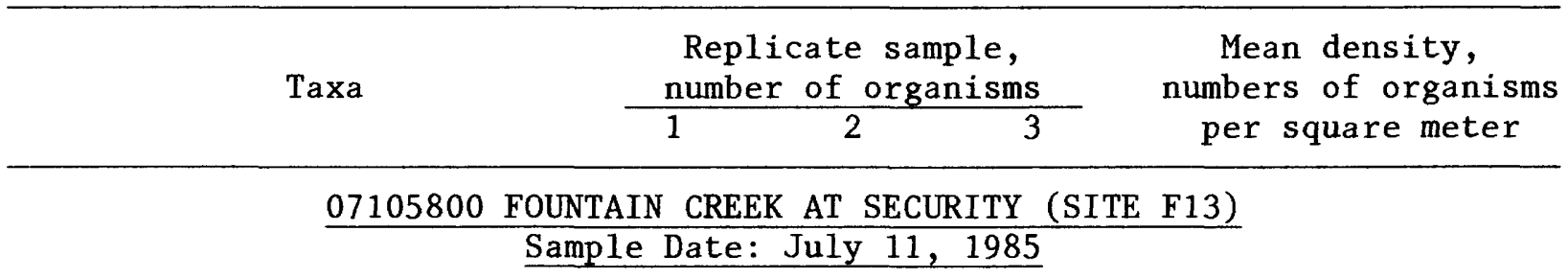

INSECTA

Ephemeroptera (mayflies)

Baetis tricaudatus

Tricorythodes minutus

2

Diptera (true flies)

Cordites sp.

Cricotopus sp.

Hemerodromia sp.

Micropsectra sp.

Ormosia sp.

Orthocladius sp.

Parametriocnemus sp.

Simulium arcticum

Tabanus sp.

Thienemanniella sp.

Chironomidae pupa

Coleoptera (beetles)

Zaitzevia parvula

Hemiptera (true bugs)

Corixidae

COLLEMBOLA (springtails)

Isotomurus palustris

OLIGOCHAETA (worms)

Limnodrilus $\mathrm{sp}$.

920

TURBELLARIA (flat worms)

Polycelis coronata

0

COELENTERATA (hydroids)

Hydroida

TOTAL
0

1,000
1

12

0

2

4

0

2

2

52

170

4

0

0

14

2

0

2

7

14

43

7

54

29

400

1,500

36

7

7

200

7

0

0

2

0

7

4

4

.

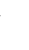

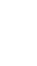

(

(2)


Table 19.--Species list, replicate samples, and mean density of benthic invertebrates for selected sites on Fountain and Monument Creeks--Continued

$\begin{array}{cccc}\text { Taxa } & \begin{array}{c}\text { Replicate sample, } \\ \text { number of organisms }\end{array} & \begin{array}{c}\text { Mean density, } \\ \text { numbers of organisms } \\ \text { per square meter }\end{array} \\ \frac{07105800 \text { FOUNTAIN CREEK AT SECURITY (SITE F13) }}{\text { Sample Date: August 12, 1985 }}\end{array}$

INSECTA

Diptera (true flies)

Dixella sp.

Micropsectra sp.

Orthocladius sp.

Parametriocnemius sp.

Paratanytarsus sp.

OLIGOCHAETA (worms)

Limnodrilus sp.

16

10

4

110

TOTAL

$21 \quad 14$

9

160

07105800 FOUNTAIN CREEK AT SECURITY (SITE F13)

Sample Date: October 28, 1985

INSECTA

Ephemeroptera (mayflies)

Ephemerella inermis

1

0

0

4

Diptera (true flies)

Micropsectra sp.

Orthocladius sp.

Parametriocemus sp.

Chironomidae pupa

$\begin{array}{rrrr}1 & 0 & 0 & 4 \\ 1 & 0 & 1 & 7 \\ 0 & 3 & 1 & 14 \\ 2 & 0 & 0 & 7\end{array}$

Coleoptera (beetles)

Zaitzevia parvula

1

0

0

4

OLIGOCHAETA (worms)

Tubificidae

200

160

130

1,700

TURBELLARIA ( $\mathrm{flat}$ worms)

Polycelis coronata

1

1

0

7

TOTAL

210

160

130

1,700 
Table 19.--Species list, replicate samples, and mean density of benthic invertebrates for selected sites on Fountain and Monument Creeks--Continued

\begin{tabular}{|c|c|c|}
\hline \multirow[t]{2}{*}{ Taxa } & $\begin{array}{l}\text { Replicate sample, } \\
\text { number of organisms }\end{array}$ & $\begin{array}{l}\text { Mean density, } \\
\text { numbers of organisms }\end{array}$ \\
\hline & $\begin{array}{lll}1 & 2 & 3\end{array}$ & per square meter \\
\hline
\end{tabular}

\section{FOUNTAIN CREEK AT SECURITY (SITE F13)}

\section{Sample Date: April 14, 1986}

INSECTA

Diptera (true flies)

Cricotopus sp.

Diamesa sp.

Eukiefferiella sp.

Orthocladius sp.

Chironomidae pupa

22

0

02

$36 \quad 20$

$0 \quad 2$
11

1

0

33

1
130

4

7

320

11

\section{CRUSTACEA}

Isopoda (sow bugs)

2

2

0

14

OLIGOCHAETA (worms)

Eiseniella tetraedra

Tubificidae

$\begin{array}{rrrr}2 & 2 & 0 & 14 \\ 180 & 200 & 150 & 1,900 \\ 240 & 230 & 200 & 2,400\end{array}$

TOTAL

\begin{tabular}{c}
$240 \quad 230 \quad 200$ \\
07105800 FOUNTAIN CREEK AT SECURITY (SITE F13) \\
\hline Sample Date: July $10, \quad 1986$
\end{tabular}

Sample Date: July 10, 1986

INSECTA

Ephemeroptera (mayflies)

Baetis bicaudatus

Baetis tricaudatus

Tricorythodes minutus

$0 \quad 0$

$0 \quad 0$

$8 \quad 0$

4

4

14

14

29

Diptera (true flies)

Chironomus sp.

Cricotopus sp.

Eukiefferiella sp.

Parametriocnemus sp.

Simulium vittatum complex

Chironomidae pupa

sp.

8
32
4
8
0
0

0
4
0
0
0
0

0

29

260

14

29

14

14

OLIGOCHAETA (worms)

Tubificidae

300

50

300

2,400

TOTAL

360

54

350

2,800 
Table 19.--Species list, replicate samples, and mean density of benthic invertebrates for selected sites on Fountain and Monument Creeks--Continued

$\begin{array}{cccc}\text { Taxa } & \begin{array}{c}\text { Replicate sample, } \\ \text { number of organisms }\end{array} & \begin{array}{c}\text { Mean density, } \\ \text { numbers of organisms } \\ \text { per square meter }\end{array} \\ \frac{07105800 \text { FOUNTAIN CREEK AT SECURITY (SITE F13) }}{2} & \text { Sample Date: August 25, 1986 }\end{array}$

INSECTA

Diptera (true flies)

Parametriocnemus sp.

Prodiamesa sp.

Chironomidae pupa

Empididae pupa

Tipulidae pupa

$\begin{array}{rrrr}0 & 1 & 1 & 7 \\ 4 & 23 & 5 & 120 \\ 0 & 2 & 1 & 11 \\ 0 & 1 & 0 & 4 \\ 0 & 2 & 3 & 18\end{array}$

OLIGOCHAETA (worms)

$\begin{array}{lllll}\text { Eiseniella tetraedra } & 0 & 1 & 2 & 11\end{array}$

Limnodrilus sp.

$\begin{array}{llll}0 & 24 & 7 & 110\end{array}$

TOTAL

$\begin{array}{lllll}4 & 54 & 19 & \cdot & 280\end{array}$

07105800 FOUNTAIN CREEK AT SECURITY (SITE F13)

INSECTA

Sample Date: November 5, 1986

Ephemeroptera (mayflies)

Ephemerella infrequens

1

0

0

4

Plecoptera (stone flies)

Capniidae

1

0

0

4

Diptera (true flies)

Chironomus sp.

Micropsectra sp.

Orthocladius sp.

Palpomyia complex

Parametricnemus sp.

Prodiamesa sp.

Tipulidae pupae

0

1

1

0

5

7

1

Coleoptera

Circulionidae

0

1

0

4

COLLEMBOLA (springtails)

Isotomurus palustris

0

0

1

4

OLIGOCHAETA (worms)

Limnodrilus $\mathrm{sp}$.

Tubificidae

740

240

86

3,800

0

4

0

14

TOTAL

760

250

90

3,900 
Table 19.--species list, replicate samples, and mean density of benthic invertebrates for selected sites on Fountain and Monument Creeks--Continued

$\begin{array}{llcc}\text { Taxa } & \begin{array}{c}\text { Replicate sample, } \\ \text { number of organisms }\end{array} & \begin{array}{c}\text { Mean density, } \\ \text { numbers of organisms } \\ \text { per square meter }\end{array} \\ \frac{07105800 \text { FOUNTAIN CREEK AT SECURITY (SITE F13) }}{\text { Sample Date: April 27, 1987 }}\end{array}$

INSECTA

Ephemeroptera (mayflies)

Ameletus sp.

Ephemerella inermis

$\begin{array}{lll}0 & 1 & 1\end{array}$

100

7

4

Diptera (true flies)

Cricotopus sp.

Diamesa sp.

Micropsectra sp.

Orthocladius sp.

Palpomyia complex

Parametriocnemus sp.

Prodiamesa sp.

Simulium sp.

Thienemanniella sp.

Thienemannimyia sp. group

Chironomidae pupa

6

$\begin{array}{llll}6 & 0 & 0 & 21\end{array}$

$\begin{array}{llll}11 & 0 & 1 & 43\end{array}$

$\begin{array}{rrrr}1 & 0 & 0 & 11\end{array}$

$\begin{array}{llll}40 & 3 & 0 & 150\end{array}$

$\begin{array}{llll}0 & 0 & 1 & 4\end{array}$

$\begin{array}{llll}370 & 6 & 8 & 1,400\end{array}$

$\begin{array}{llll}17 & 0 & 0 & 61\end{array}$

$\begin{array}{llll}0 & 0 & 1 & 4\end{array}$

$\begin{array}{llll}1 & 0 & 1 & 7\end{array}$

$\begin{array}{llll}1 & 0 & 0 & 4\end{array}$

$\begin{array}{llll}8 & 2 & 3 & 47\end{array}$

Coleoptera (beetles)

Dytiscus sp.

1

0

0

4

OLIGOCHAETA (worms)

Eiseniella tetraedra

3,700

0

4

43

Limodrilus $\mathrm{sp}$.

150

440

16,000

TOTAL

4,200

160

460

18,000 
Table 19.--Species list, replicate samples, and mean density of benthic invertebrates for selected sites on Fountain and Monument Creeks--Continued

\begin{tabular}{|c|c|}
\hline & $\begin{array}{l}\text { Replicate sample, } \\
\text { number of organisms }\end{array}$ \\
\hline & $\begin{array}{lll}1 & 2 & 3\end{array}$ \\
\hline
\end{tabular}

Mean density, numbers of organisms per square meter

\section{FOUNTAIN CREEK AT SECURITYY (SITE F13)}

Sample Date: July 15, 1987

INSECTA

Ephemeroptera (mayflies)

Tricorythodes sp.

2

1

5

29

Diptera (true flies)

Chironomus sp.

Orthocladius sp.

Palpomyia complex

Parametriocnemus sp.

Phaenopsectra sp.

$S$ imulium sp.

Chironomidae pupa

$\begin{array}{rrrr}0 & 0 & 1 & 4 \\ 2 & 0 & 2 & 14 \\ 0 & 0 & 1 & 4 \\ 19 & 19 & 39 & 280 \\ 1 & 0 & 0 & 4 \\ 0 & 1 & 8 & 32 \\ 3 & 2 & 2 & 25\end{array}$

\section{CRUSTACEA}

Isopoda (sow bugs)

Asellus sp.

0

0

1

4

OLIGOCHAETA (worms)

Limnodrilus sp.

580

420

730

6,200

TOTAL

610

440

790

6,600 
Table 19.--Species list, replicate samples, and mean density of benthic invertebrates for selected sites on Fountain and Monument Creeks--Continued

\begin{tabular}{|c|c|c|}
\hline \multirow[t]{2}{*}{ Taxa } & $\begin{array}{l}\text { Replicate sample, } \\
\text { number of organisms }\end{array}$ & \multirow{2}{*}{$\begin{array}{l}\text { Mean density, } \\
\text { numbers of organisms } \\
\text { per square meter }\end{array}$} \\
\hline & $\begin{array}{lll}1 & 2 & 3\end{array}$ & \\
\hline \multicolumn{3}{|c|}{07105800 FOUNTAIN CREEK AT SECURITY (SITE F13) } \\
\hline
\end{tabular}

INSECTA

Ephemeroptera (mayflies)

$\begin{array}{lllll}\text { Baetis tricaudatus } & 0 & 0 & 5 & 18 \\ \text { Tricorythodes minutus } & 1 & 0 & 6 & 25\end{array}$

Diptera (true flies)

Chironomus sp.

Cricotopus sp.

Cryptochironomus sp.

Eukiefferiella sp.

Parametriocnemus sp.

Thienemannimyia sp. group

Chironomidae pupa

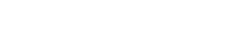

1

$0 \quad 0$

$0 \quad 1$

$0 \quad 0$

$6 \quad 17$

$0 \quad 0$

$1 \quad 0$

18

25

Hemiptera (true bugs)

Corixidae

0

2

7

OLIGOCHAETA (worms)

Limnodrilus sp.

34

71

200

1,100

TOTAL

43

89

240

1,300

07105800 FOUNTAIN CREEK AT SECURITY (SITE F13)

Sample Date: November 4, 1987

INSECTA

Diptera (true flies)

Orthocladius sp.

Parametriocnemus sp.

Pericoma sp.

Chironomidae pupa

$\begin{array}{rlll}4 & 0 & 0 & 1 \\ 8 & 8 & 4 & 72 \\ 12 & 0 & 0 & 43 \\ 4 & 0 & 0 & 14\end{array}$

OLIGOCHAETA (worms)

Eiseniella tetraedra

0

Limnodrilus sp.

94

0

4
440

14

20

620

450

4,100

TOTAL

120

4,300 
Table 19.--species list, replicate samples, and mean density of benthic invertebrates for selected sites on Fountain and Monument Creeks--Continued

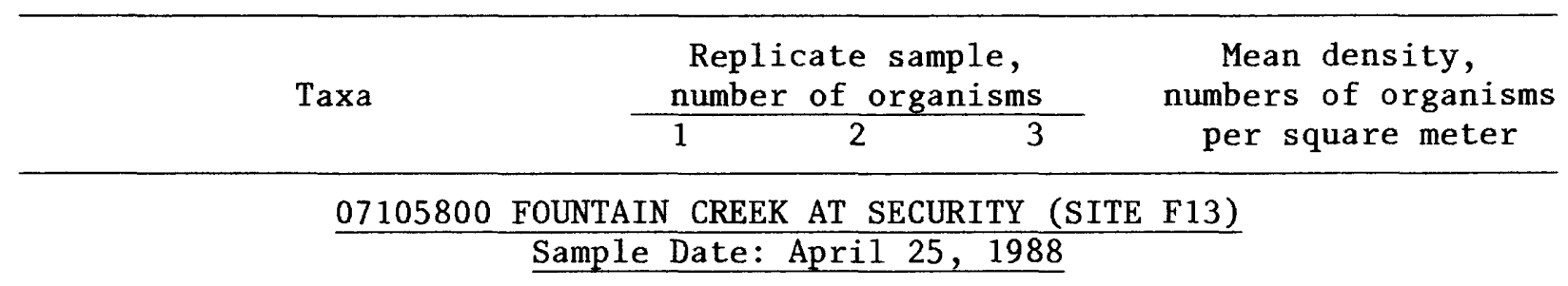

INSECTA

Ephemeroptera (mayflies)

Callibaetis sp.

1

1

0

7

Trichoptera (caddisflies)

Hydropsyche $\mathrm{sp.}$

0

1

0

4

Diptera (true flies)

Cricotopus sp.

6

Diamesa sp.

Eukiefferiella sp.

Micropsectra sp.

Orthocladius sp.

Pagastia sp.

Parametriocnemus sp.

Tipula sp.

Chironomidae pupa

Tabanidae

Coleoptera (beetles)

Phanocerus sp.

0

$$
1
$$

0

\section{CRUSTACEA}

Isopoda (sow bugs)

Asellus sp.

1

0

0

4

Amphipoda (sideswimmers)

Hyalella azteca

0

0

1

4

OLIGOCHAETA (worms)

Eiseniella tetraedra

Limodrilus sp.

TOTAL
11

420

510
18

160

230
160

2,300

3,000 
Table 19.--Species list, replicate samples, and mean density of benthic invertebrates for selected sites on Fountain and Monument Creeks--Continued

\begin{tabular}{|c|c|c|c|c|}
\hline \multirow[t]{2}{*}{ Taxa } & \multicolumn{3}{|c|}{$\begin{array}{l}\text { Replicate sample, } \\
\text { number of organisms }\end{array}$} & \multirow{2}{*}{$\begin{array}{l}\text { Mean density, } \\
\text { numbers of organisms } \\
\text { per square meter }\end{array}$} \\
\hline & 1 & 2 & 3 & \\
\hline \multicolumn{5}{|c|}{07105800 FOUNTAIN CREEK AT SECURITY (SITE F13) } \\
\hline$\underline{\text { Samp }}$ & Date & une 30 , & 988 & \\
\hline \multicolumn{5}{|l|}{ INSECTA } \\
\hline \multicolumn{5}{|l|}{ Ephemeroptera (mayflies) } \\
\hline Baetis tricaudatus & 2 & 1 & 0 & 11 \\
\hline Tricorythodes minutus & 0 & 1 & 0 & 4 \\
\hline \multicolumn{5}{|l|}{ Plecoptera (stoneflies) } \\
\hline Pteronarcella badia & 0 & 0 & 1 & 4 \\
\hline \multicolumn{5}{|l|}{ Diptera (true flies) } \\
\hline Micropsectra sp. & 1 & 0 & 0 & 4 \\
\hline Orthocladius sp. & 0 & 2 & 0 & 7 \\
\hline Pagastia sp. & 0 & 0 & 3 & 11 \\
\hline Parametriocnemus sp. & 5 & 21 & 15 & 150 \\
\hline Protanyderus margarita & 0 & 0 & 1 & 4 \\
\hline Simulium sp. & 0 & 1 & 0 & 4 \\
\hline Thienemannimyia sp. group & 0 & 0 & 1 & 4 \\
\hline Chironomidae pupa & 0 & 1 & 2 & 11 \\
\hline \multicolumn{5}{|l|}{ Hemiptera (true bugs) } \\
\hline Tritorixa sp. & 0 & 1 & 0 & 4 \\
\hline \multicolumn{5}{|l|}{ OLIGOCHAETA (worms) } \\
\hline Eiseniella tetraedra & 0 & 0 & 1 & 4 \\
\hline Limnodrilus sp. & 5 & 10 & 5 & 72 \\
\hline TOTAL & 13 & 38 & 29 & 290 \\
\hline \multicolumn{5}{|c|}{07105800 FOUNTAIN CREEK AT SECURITY (SITE F13) } \\
\hline Sample & ate: & tember & 1988 & \\
\hline \multicolumn{5}{|l|}{ INSECTA } \\
\hline \multicolumn{5}{|l|}{ Ephemeroptera (mayflies) } \\
\hline Tricorythodes minutus & 0 & 0 & 8 & 29 \\
\hline \multicolumn{5}{|l|}{ Diptera (true flies) } \\
\hline Cricotopus sp. & 2 & 16 & 32 & 180 \\
\hline Erioptera sp. & 0 & 4 & 0 & 14 \\
\hline Eukiefferiella sp. & 0 & 4 & 24 & 100 \\
\hline Micropsectra sp. & 0 & 28 & 24 & 190 \\
\hline orthocadius sp. & 0 & 4 & 32 & 130 \\
\hline Parametriocnemus sp. & 7 & 890 & 2,000 & 10,000 \\
\hline Simulium sp. & 0 & 8 & 8 & 57 \\
\hline Chironomidae pupa & 2 & 48 & 48 & 350 \\
\hline \multicolumn{5}{|l|}{ OLIGOCHAETA（worms） } \\
\hline Tubificidae & 95 & 1,500 & 2,100 & 13,000 \\
\hline TOTAL & 110 & 2,500 & 4,300 & 24,000 \\
\hline
\end{tabular}


Table 19.--Species list, replicate samples, and mean density of benthic invertebrates for selected sites on Fountain and Monument Creeks--Continued

Replicate sample,

Taxa
Mean density, numbers of organisms per square meter

07103780 MONUMENT CREEK ABOVE NORTH GATE BOULEVARD AT U.S. AIR FORCE ACADEMY (SITE M5) Sample Date: April 16, 1985

INSECTA

Ephemeroptera (mayflies) Baetis tricaudatus Ephemerella inermis 2

0

0

11

Plecoptera (stoneflies)

Chloroperlidae

1

0

0

4

Diptera (true flies)

Cricotopus sp.

Diamesa sp.

Erioptera sp.

Orthocladius sp.

Palpomyia complex

Prosimulium sp.

Thienemanniella sp.

Chironomidae pupa

4
4
2
7
1
0
3
2

\section{5}

1

0

4

0

1

0

0

1
2

11

OLIGOCHAETA (worms)

Limnodrilus sp.

62

3

4

250

TURBELLARIA (flat worms)

Polycelis coronata

0

1

0

4

TOTAL

88

16

24

460 
Table 19.--Species list, replicate samples, and mean density of benthic invertebrates for selected sites on Fountain and Monument Creeks--Continued

\begin{tabular}{|c|c|c|c|c|}
\hline Taxa & \multicolumn{3}{|c|}{$\begin{array}{l}\text { Replicate sample, } \\
\text { number of organisms }\end{array}$} & $\begin{array}{l}\text { Mean density, } \\
\text { numbers of organisms } \\
\text { per square meter }\end{array}$ \\
\hline \multicolumn{5}{|c|}{$\frac{07103780 \text { MONUMENT CREEK ABOVE NORTH GATE BOULEVARD }}{\frac{\text { AT U.S. AIR FORCE ACADEMY (SITE M5) }}{\text { Sample Date: July 11, 1985 }}}$} \\
\hline $\begin{array}{l}\text { INSECTA } \\
\text { Ephemeroptera (mayflies) } \\
\text { Baetis tricaudatus } \\
\text { Drunella grandis grandis } \\
\text { Epeorus longimanus } \\
\text { Tricorythodes minutus }\end{array}$ & $\begin{array}{r}770 \\
0 \\
190 \\
32\end{array}$ & $\begin{array}{r}370 \\
2 \\
140 \\
10\end{array}$ & $\begin{array}{r}580 \\
0 \\
160 \\
48\end{array}$ & $\begin{array}{r}6,200 \\
7 \\
1,800 \\
320\end{array}$ \\
\hline $\begin{array}{l}\text { Plecoptera (stoneflies) } \\
\text { Pteronarcella badia } \\
\text { Chloroperlidae } \\
\text { Perlodidae }\end{array}$ & $\begin{array}{l}4 \\
4 \\
0\end{array}$ & $\begin{array}{l}0 \\
6 \\
4\end{array}$ & $\begin{array}{l}0 \\
4 \\
4\end{array}$ & $\begin{array}{l}14 \\
50 \\
29\end{array}$ \\
\hline $\begin{array}{l}\text { Trichoptera (caddisflies) } \\
\text { Hydropsyche sp. }\end{array}$ & 40 & 14 & 36 & 320 \\
\hline $\begin{array}{l}\text { Diptera (true flies) } \\
\text { Antocha sp. } \\
\text { Chelifera sp. } \\
\text { Cordites sp. } \\
\text { Cricotopus sp. } \\
\text { Hexatoma sp. } \\
\text { Micropsectra sp. } \\
\text { Orthocladius sp. } \\
\text { Palpomyia complex } \\
\text { Parametriocnemus sp. } \\
\text { Phaenopsectra sp. } \\
\text { Simulium sp. } \\
\text { Thienemanniella sp. } \\
\text { Chironomidae pupa }\end{array}$ & $\begin{array}{r}0 \\
0 \\
36 \\
60 \\
0 \\
0 \\
28 \\
4 \\
76 \\
100 \\
280 \\
0 \\
16\end{array}$ & $\begin{array}{r}2 \\
2 \\
24 \\
110 \\
0 \\
20 \\
110 \\
8 \\
86 \\
22 \\
22 \\
2 \\
12\end{array}$ & $\begin{array}{r}0 \\
4 \\
12 \\
96 \\
2 \\
12 \\
72 \\
8 \\
140 \\
52 \\
100 \\
8 \\
4\end{array}$ & $\begin{array}{r}7 \\
22 \\
260 \\
940 \\
7 \\
120 \\
750 \\
72 \\
1,100 \\
620 \\
1,500 \\
36 \\
120\end{array}$ \\
\hline $\begin{array}{l}\text { Coleoptera (beetles) } \\
\text { Heterlimnius corpulentus } \\
\text { Hydrobios sp. }\end{array}$ & $\begin{array}{l}4 \\
0\end{array}$ & $\begin{array}{l}6 \\
2\end{array}$ & $\begin{array}{l}0 \\
0\end{array}$ & $\begin{array}{r}36 \\
7\end{array}$ \\
\hline $\begin{array}{l}\text { CRUSTACEA } \\
\text { Amphipoda (scuds) } \\
\text { Hyalella azteca }\end{array}$ & 0 & 0 & 4 & 14 \\
\hline $\begin{array}{l}\text { OLIGOCHAETA (worms) } \\
\text { Limnodrilus sp. }\end{array}$ & 560 & 120 & 420 & 3,900 \\
\hline $\begin{array}{l}\text { COELENTERATA (hydroids) } \\
\text { Hydroida }\end{array}$ & 0 & 8 & 0 & 29 \\
\hline TOTAL & 2,200 & 1,100 & 1,800 & 18,000 \\
\hline
\end{tabular}


Table 19.--Species list, replicate samples, and mean density of benthic invertebrates for selected sites on Fountain and Monument Creeks--Continued

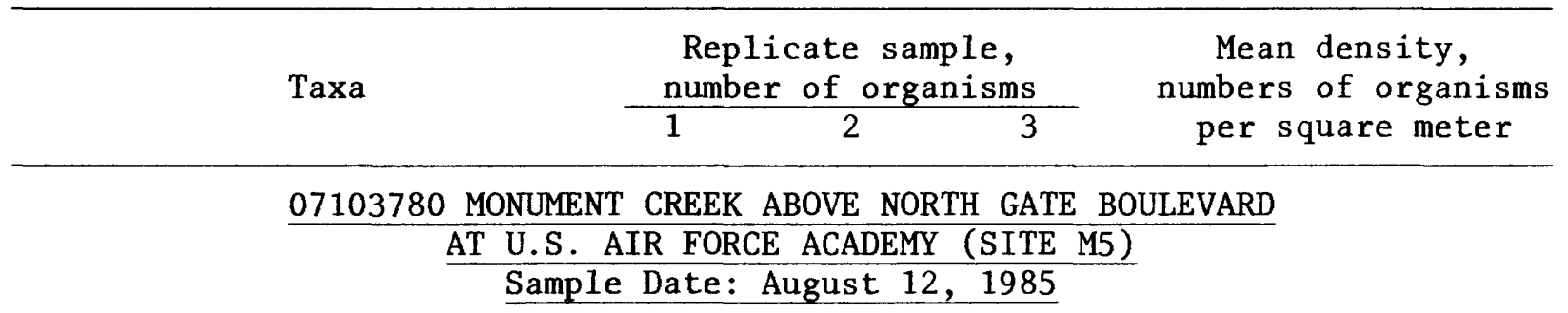

INSECTA

Ephemeroptera (mayflies)

Baetis bicaudatus

Baetis tricaudatus

Tricorythodes minutus

540

Plecoptera (stoneflies)

Chloroperlidae

Trichoptera (caddisflies)

Hydropsyche sp.

Diptera (true flies)

Eukiefferiella sp.

Hexatoma sp.

Parametriocnemus sp.

Simulium sp.

Thienemanniella sp.

Chironomidae pupa

Coleoptera (beetles)

optioservus castanipennis

Zaitzevia parvula

HYDRACARINA (water mites)

Sperchon sp.

0

140
0

140

320

0

12

0
4

60

16

140

780

$\begin{array}{rr}160 & 600 \\ 56 & 12 \\ 0 & 4\end{array}$

4,700

460

14

57

16

0

0

(2)

40

0

16

560

8

60

$40 \quad 96 \quad 1,600$

56

12

860

4

220

86

14

14

$\begin{array}{lll}0 & 4 & 14 \\ 0 & 0 & 14\end{array}$

COLLEMBOLA (springtails)

Isotomurus palustris

0

4

0

14

OLIGOCHAETA (worms)

Limnodrilus sp.

4

0

4

29

TOTAL

1,300

320

1,000

9,500 
Table 19.--Species list, replicate samples, and mean density of benthic invertebrates for selected sites on Fountain and Monument Creeks--Continued

$\begin{array}{lll}\text { Taxa } & \begin{array}{c}\text { Replicate sample, } \\ \text { number of organisms }\end{array} & \begin{array}{c}\text { Mean density, } \\ \text { numbers of organisms } \\ \text { per square meter }\end{array} \\ \frac{\text { 07103780 MONUMENT CREEK ABOVE NORTH GATE BOULEVARD }}{\text { AT U.S. AIR FORCE ACADEMY (SITE M5) }} & \frac{\text { Sample Date: October 29, 1985 }}{2}\end{array}$

INSECTA

Ephemeroptera (mayflies)

Baetis bicaudatus

Baetis tricaudatus

Ephemerella inermis

Paraleptophlebia heteronea

Tricorythodes minutus

Plecoptera (stoneflies)

Isoperla sobria

Pteronarcella badia

Chloroperlidae

Perlodidae

$\begin{array}{rrr}28 & 110 & 120 \\ 660 & 630 & 60 \\ 150 & 140 & 48 \\ 7 & 8 & 0 \\ 2 & 4 & 0\end{array}$

920

$60 \quad 4,800$

48

1,200

0

54

22

16

12

100

0

4

0

14

520

8

60

140

Trichoptera (caddisflies)

Hydropsyche sp.

Diptera (true flies)

Antocha sp.

Cordites sp.

Cricotopus sp.

Diamesa sp.

Eukiefferiella sp.

Hexatoma sp.

Micropsectra sp.

Orthocladius sp.

Palpomyia complex

Parametriocnemus sp.

Prosimulium sp.

Chironomidae pupa

Coleoptera (beetles)

optioservus castsnipennis

Zaitzevia parvula

\section{OLIGOCHAETA (worms)}

Tubificidae 
Table 19.--species list, replicate samples, and mean density of benthic invertebrates for selected sites on Fountain and Monument Creeks--Continued

Replicate sample,

Taxa number of organisms

123

Mean density, numbers of organisms per square meter

07103780 MONUMENT CREEK ABOVE NORTH GATE BOULEVARD AT U.S. AIR FORCE ACADEMY (SITE M5) Sample Date: April 14, 1986

INSECTA

Ephemeroptera (mayflies)

Baetis bicaudatus

Baetis tricaudatus

Ephemerella inermis

0

39

35

Plecoptera (stoneflies)

Isoperla sobria

Trichoptera (caddisflies) Hydropsyche occidentalis Hydropsyche sp.

Diptera (true flies)

Cricotopus sp.

Diamesa sp.

Eukiefferiella sp.

Hexatoma sp.

Orthocladius sp.

Palpomyia complex

Parametriocnemus sp.

Thienemannimyia sp.

Thienemannimyia sp. group

OLIGOCHAETA (worms)

Eiseniella tetraedra

Tubificidae

TOTAL

2

440

820

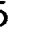

2

2

25

56

34

0

34

3

460

260

190

10

3

32

$\begin{array}{rrrr}2 & 24 & 8 & 120 \\ 0 & 4 & 8 & 43 \\ 4 & 4 & 1 & 22 \\ 4 & 1 & 1 & 22 \\ 180 & 64 & 48 & 1,000 \\ 30 & 20 & 24 & 270 \\ 26 & 72 & 0 & 350 \\ 0 & 0 & 24 & 86 \\ 4 & 8 & 0 & 43\end{array}$

1

0

11

310

230

3,500

610

390

6,400 
Table 19.--Species list, replicate samples, and mean density of benthic invertebrates for selected sites on Fountain and Monument Creeks--Continued

\begin{tabular}{|c|c|c|}
\hline \multirow[t]{2}{*}{ Taxa } & $\begin{array}{l}\text { Replicate sample, } \\
\text { number of organisms }\end{array}$ & \multirow{2}{*}{$\begin{array}{l}\text { Mean density, } \\
\text { numbers of organisms } \\
\text { per square meter }\end{array}$} \\
\hline & $\begin{array}{lll}1 & 2 & 3\end{array}$ & \\
\hline \multicolumn{3}{|c|}{$\frac{07103780 \text { MONUMENT CREEK ABOVE NORTH GATE BOU }}{\frac{\text { AT U.S. AIR FORCE ACADEMY (SITE M5) }}{\text { Sample Date: July 10, } 1986}}$} \\
\hline
\end{tabular}

INSECTA

Ephemeroptera (mayflies)

Baetis bicaudatus 92

Baetis tricaudatus

Cinygmula sp.

Tricorythodes minutus

Trichoptera (caddisflies)

Cheumatopsyche sp.

Hydropsyche sp.

Hydroptila sp.

Diptera (true flies)

Cordites sp.

Cricotopus sp.

Chrionomus sp.

Eukiefferiella sp.

Hexatoma sp.

Limnophora aequifrons

Micropsectra sp.

Orthocladius sp.

Palpomyia complex

Parametriocnemus sp.

Prosimulium sp.

Simulium vittatum complex

Thienemanniella sp.

Thienemannimyia sp. group

Chironomidae pupa

COLLEMBOLA (springtails)

Isotomurus palustris

OLIGOCHAETA (worms)

Tubificidae

TOTAL
880

310

520

6,200

170

12

44

340

150

4

32

80

16

360

40

56

360

14

20

0

4
12

4

0

0

8

0
28

0

8

0

24

4

0

4

0

14

1,300

1,100

1,200

13,000 
Table 19.--Species 1ist, replicate samples, and mean density of benthic invertebrates for selected sites on Fountain and Monument Creeks--Continued

\begin{tabular}{|c|c|c|c|c|}
\hline \multirow[t]{2}{*}{ Taxa } & \multicolumn{3}{|c|}{$\begin{array}{l}\text { Replicate sample, } \\
\text { number of organisms }\end{array}$} & \multirow{2}{*}{$\begin{array}{l}\text { Mean density, } \\
\text { numbers of organisms } \\
\text { per square meter }\end{array}$} \\
\hline & 1 & 2 & 3 & \\
\hline \multicolumn{5}{|c|}{$\frac{07103780 \text { MONUMENT CREEK ABOVE NORTH GATE BOULEVARD }}{\frac{\text { AT U.S. AIR FORCE ACADEMY (SITE M5) }}{\text { Sample Date: AUGUST } 25,1986}}$} \\
\hline \multicolumn{5}{|c|}{ 1 } \\
\hline $\begin{array}{l}\text { Ephemeroptera (mayflies) } \\
\text { Baetis bicaudatus } \\
\text { Baetis tricaudatus } \\
\text { Ephemerella infrequens } \\
\text { Tricorythodes minutus }\end{array}$ & $\begin{array}{r}150 \\
780 \\
4 \\
8\end{array}$ & $\begin{array}{r}150 \\
610 \\
8 \\
8\end{array}$ & $\begin{array}{r}100 \\
150 \\
4 \\
36\end{array}$ & $\begin{array}{r}1,400 \\
5,600 \\
57 \\
190\end{array}$ \\
\hline $\begin{array}{l}\text { Plecoptera (stoneflies) } \\
\text { Chloroperlidae }\end{array}$ & 8 & 40 & 28 & 270 \\
\hline $\begin{array}{l}\text { Trichoptera (caddisflies) } \\
\text { Hydropsyche accidentalis } \\
\text { Hydropsyche sp. } \\
\text { Ochrotrichia sp. }\end{array}$ & $\begin{array}{r}96 \\
210 \\
16\end{array}$ & $\begin{array}{r}300 \\
480 \\
0\end{array}$ & $\begin{array}{r}170 \\
490 \\
0\end{array}$ & $\begin{array}{r}2,000 \\
4,200 \\
57\end{array}$ \\
\hline $\begin{array}{l}\text { Diptera (true flies) } \\
\text { Cryptochironomus sp. } \\
\text { Dicranota sp. } \\
\text { Dixa sp. } \\
\text { Hexatoma sp. } \\
\text { Palpomyia complex } \\
\text { Parametriocnemius sp. } \\
\text { Prodiamesa sp. } \\
\text { Prosimulium sp. } \\
\text { Simulium sp. } \\
\text { Thienemannimyia sp. } \\
\text { Chironomidae pupa }\end{array}$ & $\begin{array}{r}4 \\
0 \\
0 \\
0 \\
4 \\
12 \\
190 \\
4 \\
12 \\
4 \\
24\end{array}$ & $\begin{array}{r}0 \\
4 \\
4 \\
4 \\
0 \\
4 \\
72 \\
0 \\
4 \\
8 \\
0\end{array}$ & $\begin{array}{r}0 \\
0 \\
0 \\
0 \\
0 \\
0 \\
150 \\
0 \\
0 \\
0 \\
0\end{array}$ & $\begin{array}{r}14 \\
14 \\
14 \\
14 \\
14 \\
57 \\
1,500 \\
14 \\
57 \\
43 \\
86\end{array}$ \\
\hline $\begin{array}{l}\text { Coleoptera (beetles) } \\
\text { Heterlimnius corpulentus } \\
\text { Zaitzevia parvula }\end{array}$ & $\begin{array}{l}0 \\
0\end{array}$ & $\begin{array}{l}4 \\
0\end{array}$ & $\begin{array}{l}8 \\
4\end{array}$ & $\begin{array}{l}43 \\
14\end{array}$ \\
\hline $\begin{array}{l}\text { Odonata (dragonflies) } \\
\text { Ophiogomphus severus }\end{array}$ & 0 & 0 & 2 & 7 \\
\hline $\begin{array}{l}\text { CRUSTACEA } \\
\text { Amphipoda (scuds) } \\
\text { Gammarus lacustris }\end{array}$ & 0 & 4 & 0 & 14 \\
\hline $\begin{array}{l}\text { OLIGOCHAETA (worms) } \\
\text { Eiseniella tetraedra } \\
\text { Limnodrilus sp. }\end{array}$ & $\begin{array}{r}28 \\
210\end{array}$ & $\begin{array}{r}20 \\
110\end{array}$ & $\begin{array}{l}16 \\
64\end{array}$ & $\begin{array}{r}230 \\
1,400\end{array}$ \\
\hline TOTAL & 1,800 & 1,800 & 1,200 & 17,000 \\
\hline
\end{tabular}


Table 19.--Species list, replicate samples, and mean density of benthic invertebrates for selected sites on Fountain and Monument Creeks--Continued

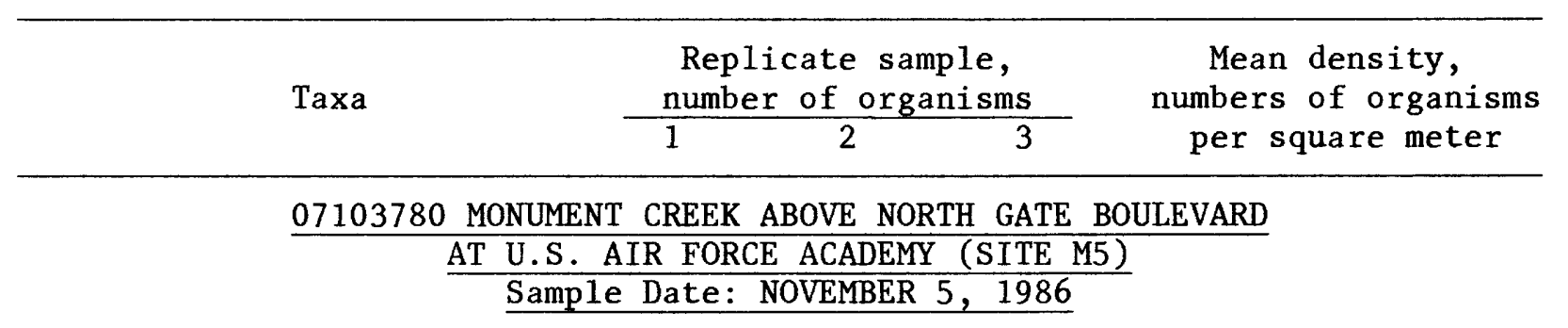

\section{INSECTA}

Ephemeroptera (mayflies)

Baetis bicaudatus

220

Baetis tricaudatus

Caenis sp.

Ephemerella infrequens

Paraleptophlebia sp.

Tricorythodes minutus

Plecoptera (stoneflies)

Cultus sp.

Isoperla sobria

Chloroperlidae

Trichoptera (caddisflies)

Cheumatopsyche sp.

Hydropsyche occidentalis

Hydropsyche sp.

Ochrotrichia sp.

Diptera (true flies)

Antocha sp.

Chelifera sp.

Cryptochironomus sp.

Diamesa sp.

Dicranota sp.

Hexatoma sp.

Micropsectra sp.

Orthocladius sp.

Palpomyia complex

Parametriocnemus sp.

Pericoma sp.

Prodiamesa sp.

Prosimulium sp.

Simulium sp.

Thienemanniella sp.

Thienemannimyia sp. group

Tipula sp.

Chironomidae pupa

Tipulidae pupa

\section{0}

130

36

$\begin{array}{rr}0 & 1 \\ 0 & 1 \\ 0 & 1 \\ 99 & 140 \\ 3 & 15 \\ 1 & 5 \\ 13 & 16 \\ 1 & 0 \\ 24 & 14 \\ 10 & 1 \\ 0 & 0 \\ 350 & 400 \\ 15 & 12 \\ 27 & 8 \\ 10 & 7 \\ 6 & 2 \\ 0 & 0 \\ 2 & 1 \\ 2 & 0\end{array}$


Table 19.--Species 1ist, replicate samples, and mean density of benthic invertebrates for selected sites on Fountain and Monument Creeks--Continued

\begin{tabular}{|c|c|c|c|c|}
\hline \multirow[t]{2}{*}{ Taxa } & \multicolumn{3}{|c|}{$\begin{array}{l}\text { Replicate sample, } \\
\text { number of organisms }\end{array}$} & \multirow{2}{*}{$\begin{array}{l}\text { Mean density, } \\
\text { numbers of organisms } \\
\text { per square meter }\end{array}$} \\
\hline & 1 & 2 & 3 & \\
\hline \multicolumn{5}{|c|}{$\begin{array}{l}\text { 07103780 MONUMENT CREEK ABOVE NORTH GATE BOULE } \\
\text { AT U.S. AIR FORCE ACADEMY (SITE M5) } \\
\text { Sample Date: NOVEMBER 5, 1986--Continued }\end{array}$} \\
\hline \multicolumn{5}{|l|}{ INSECTA--Continued } \\
\hline $\begin{array}{l}\text { Coleoptera (beetles) } \\
\text { Helichus sp. } \\
\text { Heterelmis corpulentus } \\
\text { Optioservus castanipennis } \\
\text { Zaitzevia parvula }\end{array}$ & $\begin{array}{l}1 \\
0 \\
8 \\
1\end{array}$ & $\begin{array}{l}0 \\
0 \\
4 \\
0\end{array}$ & $\begin{array}{r}04 \\
1 \\
7 \\
0\end{array}$ & $\begin{array}{r}4 \\
68 \\
4\end{array}$ \\
\hline HYDRACARINA & 2 & 0 & 0 & 7 \\
\hline $\begin{array}{l}\text { OLIGOCHAETA (worms) } \\
\text { Eiseniella tetraedra } \\
\text { Limnodrilus sp. }\end{array}$ & $\begin{array}{r}0 \\
420\end{array}$ & $\begin{array}{r}0 \\
130\end{array}$ & $\begin{array}{r}9 \\
230\end{array}$ & $\begin{array}{r}32 \\
2,800\end{array}$ \\
\hline TOTAL & 2,300 & 1,400 & 1,700 & 20,000 \\
\hline
\end{tabular}


Table 19.--Species 1ist, replicate samples, and mean density of benthic invertebrates for selected sites on Fountain and Monument Creeks--Continued

\begin{tabular}{|c|c|c|c|c|}
\hline \multirow[t]{2}{*}{ Taxa } & \multicolumn{3}{|c|}{$\begin{array}{l}\text { Replicate sample, } \\
\text { number of organisms }\end{array}$} & \multirow{2}{*}{$\begin{array}{l}\text { Mean density, } \\
\text { numbers of organisms } \\
\text { per square meter }\end{array}$} \\
\hline & 1 & 2 & 3 & \\
\hline \multicolumn{5}{|c|}{$\frac{07103780 \text { MONUMENT CREEK ABOVE NORTH GATE BOULEVARD }}{\frac{\text { AT U.S. AIR FORCE ACADEMY (SITE M5) }}{\text { SAMPLE DATE APRIL 27, 1987 }}}$} \\
\hline \multicolumn{5}{|l|}{ INSECTA } \\
\hline \multicolumn{5}{|l|}{ Ephemeroptera (mayflies) } \\
\hline Baetis bicaudatus & 1 & 5 & 0 & 21 \\
\hline Baetis tricaudatus & 47 & 13 & 7 & 240 \\
\hline Ephemerella inermis & 10 & 3 & 13 & 93 \\
\hline \multicolumn{5}{|l|}{ Plecoptera (stoneflies) } \\
\hline Isoperla sp. & 0 & 0 & 1 & 4 \\
\hline Chloroperlidae & 0 & 0 & 1 & 4 \\
\hline \multicolumn{5}{|l|}{ Trichoptera (caddisflies) } \\
\hline Cheumatopsyche sp. & 2 & 1 & 0 & 11 \\
\hline Hydropsyche sp. & 11 & 9 & 5 & 90 \\
\hline \multicolumn{5}{|l|}{ Diptera (true flies) } \\
\hline Cricotopus $\mathrm{sp}$ & 1 & 1 & 1 & 11 \\
\hline Diamesa sp. & 0 & 6 & 5 & 39 \\
\hline Micropsectra sp. & 3 & 0 & 0 & 11 \\
\hline Orthocladius sp. & 9 & 5 & 23 & 130 \\
\hline Palpomyia complex & 9 & 0 & 23 & 120 \\
\hline Parametriocnemus sp. & 64 & 44 & 190 & 1,000 \\
\hline Prodiamesa sp. & 5 & 0 & 5 & 36 \\
\hline Thienemanniella sp. & 0 & 1 & 0 & 4 \\
\hline Thienemannimyia sp. group & 2 & 0 & 0 & 7 \\
\hline Chironomidae pupa & 3 & 0 & 10 & 47 \\
\hline \multicolumn{5}{|l|}{ Coleoptera (beetles) } \\
\hline Optioservus sp. & 1 & 0 & 2 & 11 \\
\hline \multicolumn{5}{|l|}{$\begin{array}{c}\text { Odonata (dragonflies and } \\
\text { damselflies) }\end{array}$} \\
\hline Ophiogomphus severus & 0 & 0 & 1 & 4 \\
\hline \multicolumn{5}{|l|}{ CRUSTACEA } \\
\hline \multicolumn{5}{|l|}{ Amphipoda (scuds) } \\
\hline Hyalella sp. & 1 & 0 & 0 & 4 \\
\hline \multicolumn{5}{|l|}{ OLIGOCHAETA (worms) } \\
\hline Eiseniella tetraedra & 1 & 0 & 0 & 4 \\
\hline Limnodrilus sp. & 120 & 140 & 1,400 & 6,100 \\
\hline TOTAL & 290 & 230 & 1,700 & 8,000 \\
\hline
\end{tabular}


Table 19.--Species list, replicate samples, and mean density of benthic invertebrates for selected sites on Fountain and Monument Creeks--Continued

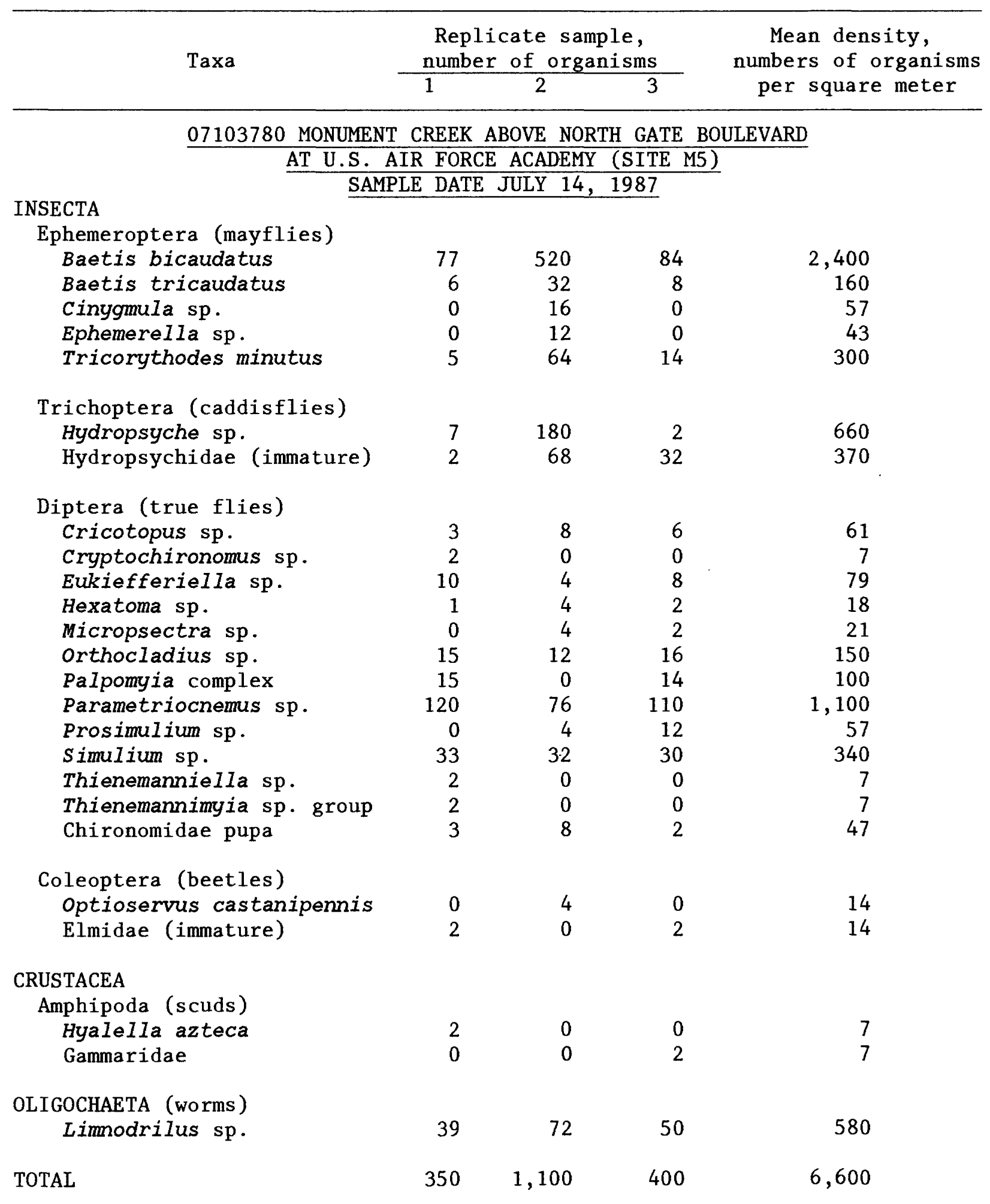


Table 19.--species list, replicate samples, and mean density of benthic invertebrates for selected sites on Fountain and Monument Creeks--Continued

\begin{tabular}{|c|c|c|c|c|}
\hline \multirow[t]{2}{*}{ Taxa } & \multicolumn{3}{|c|}{$\begin{array}{l}\text { Replicate sample, } \\
\text { number of organisms }\end{array}$} & \multirow{2}{*}{$\begin{array}{l}\text { Mean density, } \\
\text { numbers of organisms } \\
\text { per square meter }\end{array}$} \\
\hline & 1 & 2 & 3 & \\
\hline \multicolumn{5}{|c|}{$\frac{\text { 07103780 MONUMENT CREEK ABOVE NORTH GATE BOUL }}{\text { AT U.S. AIR FORCE ACADEMY (SITE M5) }}$} \\
\hline \multicolumn{5}{|l|}{ INSECTA } \\
\hline \multicolumn{5}{|l|}{ Ephemeroptera (mayflies) } \\
\hline Baetis bicaudatus & 290 & 460 & 270 & 3,700 \\
\hline Baetis tricaudatus & 72 & 40 & 4 & 420 \\
\hline Ephemerella inermis & 4 & 0 & 0 & 14 \\
\hline Tricorythodes minutus & 8 & 28 & 4 & 140 \\
\hline \multicolumn{5}{|l|}{ Plecoptera (stoneflies) } \\
\hline Megarcys sp. & 8 & 0 & 0 & 29 \\
\hline Chloroperlidae & 0 & 12 & 10 & 79 \\
\hline \multicolumn{5}{|l|}{ Trichoptera (caddisflies) } \\
\hline Hydropsyche sp. & 420 & 280 & 66 & 2,700 \\
\hline \multicolumn{5}{|l|}{ Diptera (true flies) } \\
\hline Chironomus $\mathrm{sp}$ & 0 & 4 & 0 & 14 \\
\hline Cricotopus sp. & 12 & 12 & 6 & 110 \\
\hline Cryptochironomus sp. & 4 & 0 & 2 & 22 \\
\hline Eukiefferiella sp. & 0 & 8 & 12 & 72 \\
\hline Hexatoma sp. & 12 & 36 & 12 & 220 \\
\hline Micropsectra sp. & 4 & 0 & 0 & 14 \\
\hline Palpomyia complex & 24 & 28 & 48 & 360 \\
\hline Parametriocnemus sp. & 100 & 150 & 110 & 1,300 \\
\hline Phaenopsectra sp. & 0 & 0 & 4 & 14 \\
\hline Simulium sp. & 24 & 16 & 2 & 150 \\
\hline Thienemanniella sp. & 4 & 0 & 8 & 43 \\
\hline Thienemannimyia sp. group & 0 & 0 & 4 & 14 \\
\hline \multicolumn{5}{|l|}{ Coleoptera (beetles) } \\
\hline optioservus divergens & 12 & 12 & 0 & 86 \\
\hline \multicolumn{5}{|l|}{ OLIGOCHAETA (worms) } \\
\hline Limnodrilus sp. & 36 & 40 & 96 & 620 \\
\hline TOTAL & 1,000 & 1,100 & 660 & 10,000 \\
\hline
\end{tabular}


Table 19.--Species list, replicate samples, and mean density of benthic invertebrates for selected sites on Fountain and Monument Creeks--Continued

$\frac{\text { Taxa }}{\frac{\text { number of organisms }}{1}} \begin{gathered}\begin{array}{c}\text { Replicate sample, } \\ \text { numbers of organisms } \\ \text { per square meter }\end{array} \\ \frac{07103780 \text { MONUMENT CREEK ABOVE NORTH GATE BOULEVARD }}{\frac{\text { AT U.S. AIR FORCE ACADEMY (SITE M5) }}{\text { Sample Date: NOVEMBER 4, 1987 }}}\end{gathered}$

INSECTA

Ephemeroptera (mayflies)

Baetis bicaudatus

62

Baetis tricaudatus

37

Ephemerella inermis

24

Tricorythodes minutus

24

12

27

360

200

160

220

Plecoptera (stoneflies)

Alloperla sp.

Capnia sp.

Megarcys sp.

Perlodidae

$\begin{array}{rrrr}11 & 0 & 0 & 39 \\ 6 & 0 & 0 & 21 \\ 0 & 0 & 1 & 4 \\ 2 & 0 & 2 & 14\end{array}$

Trichoptera (caddisflies)

Cheumatopsyche sp.

Hydropsyche sp.

Hydropsychidae

47

340

0

86

440

35

140

Diptera (true flies)

Cricotopus sp.

Cryptochironomus sp.

12

1

Diamesa sp.

Dicranota sp.

11

Eukiefferiella sp.

Hexatoma sp.

Micropsectra sp.

Orthocladius sp.

Pagastia sp.

Palpomyia complex

Parametriocnemus sp.

Pericoma sp.

Prosimulium sp.

Simulium sp.

Thienemanniella sp.

Thienemannimyia sp. group

Tipula sp.

Chironomidae pupa

42

13

240

1

11

86

29

5

8

290

15

19

54

6

230

40

130

16

21

0

280

47

570

1

55

4

10

27

6

2

11

8

0

130

24

130

4

61

0

61

3

54

12

43

Coleoptera (beetles)

optioservus divergens

4

1

9

50 
Table 19.--Species Iist, replicate samples, and mean density of benthic invertebrates for selected sites on Fountain and Monument Creeks--Continued

\begin{tabular}{|c|c|c|c|c|}
\hline \multirow[t]{2}{*}{ Taxa } & \multicolumn{3}{|c|}{$\begin{array}{l}\text { Replicate sample, } \\
\text { number of organisms }\end{array}$} & \multirow{2}{*}{$\begin{array}{l}\text { Mean density, } \\
\text { numbers of organisms } \\
\text { per square meter }\end{array}$} \\
\hline & 1 & 2 & 3 & \\
\hline \multicolumn{5}{|c|}{$\begin{array}{l}\text { 07103780 MONUMENT CREEK ABOVE NORTH GATE BOULE } \\
\text { AT U.S. AIR FORCE ACADEMY (SITE M5) } \\
\text { Sample Date: NOVEMBER 4, 1987--Cont ined }\end{array}$} \\
\hline \multicolumn{5}{|l|}{$\begin{array}{l}\text { CRUSTACEA } \\
\text { Amphipoda (scuds) } \\
\text { Gammarus lacustris }\end{array}$} \\
\hline \multicolumn{5}{|l|}{$\begin{array}{l}\text { MOLLUSCA } \\
\text { Gastropoda (snails) }\end{array}$} \\
\hline $\begin{array}{l}\text { OLIGOCHAETA (worms) } \\
\text { Eiseniella tetraedra } \\
\text { Limnodrilus sp. }\end{array}$ & $\begin{array}{r}5 \\
450\end{array}$ & $\begin{array}{r}0 \\
1,200\end{array}$ & $\begin{array}{r}1 \\
26\end{array}$ & $\begin{array}{r}21 \\
6,100\end{array}$ \\
\hline TOTAL & 960 & 1,500 & 490 & 10,000 \\
\hline
\end{tabular}


Table 19.--Species list, replicate samples, and mean density of benthic invertebrates for selected sites on Fountain and Monument Creeks--Continued

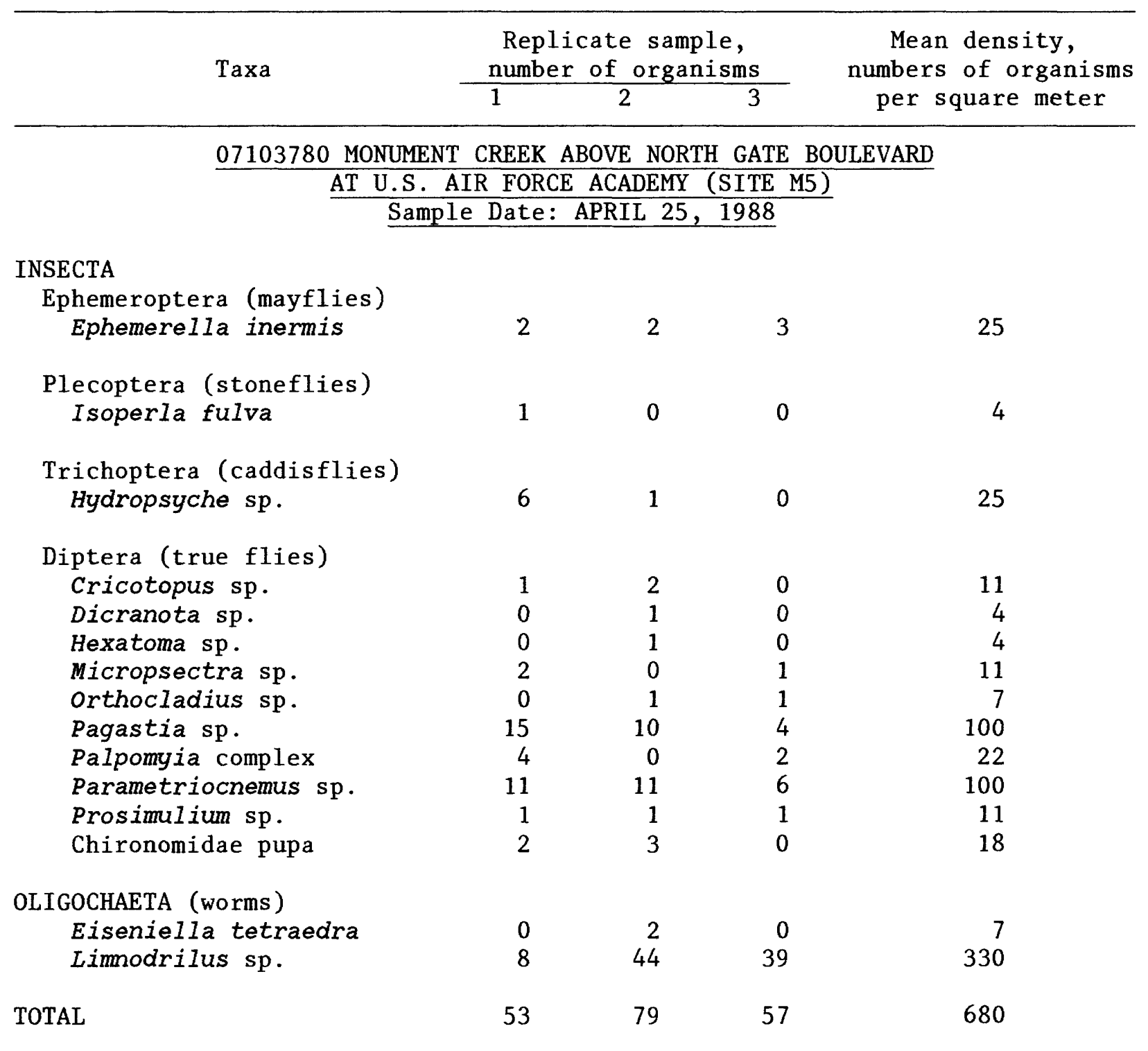


Table 19.--Species 1ist, replicate samples, and mean density of benthic invertebrates for selected sites on Fountain and Monument Creeks--Continued

\begin{tabular}{|c|c|c|c|c|}
\hline \multirow[t]{2}{*}{ Taxa } & \multicolumn{3}{|c|}{$\begin{array}{l}\text { Replicate sample, } \\
\text { number of organisms }\end{array}$} & \multirow{2}{*}{$\begin{array}{l}\text { Mean density, } \\
\text { numbers of organisms } \\
\text { per square meter }\end{array}$} \\
\hline & 1 & 2 & 3 & \\
\hline \multicolumn{5}{|c|}{$\frac{07103780 \text { MONUMENT CREEK ABOVE NORTH GATE BOULEVARD }}{\frac{\text { AT U.S. AIR FORCE ACADEMY (SITE M5) }}{\text { Sample Date: JUNE 30, 1988 }}}$} \\
\hline \multicolumn{5}{|l|}{ INSECTA } \\
\hline \multicolumn{5}{|l|}{ Ephemeroptera (mayflies) } \\
\hline Baetis bicaudatus & 240 & 200 & 290 & 2,600 \\
\hline Baetis tricaudatus & 0 & 0 & 8 & 29 \\
\hline Cinygmula sp. & 4 & 0 & 4 & 29 \\
\hline Tricorythodes minutus & 52 & 12 & 100 & 590 \\
\hline \multicolumn{5}{|l|}{ Plecoptera (stoneflies) } \\
\hline Chloroperlidae & 4 & 0 & 0 & 14 \\
\hline \multicolumn{5}{|l|}{ Trichoptera (caddisflies) } \\
\hline Hydropsyche sp. & 4 & 56 & 96 & 560 \\
\hline Ochrotrichia sp. & 4 & 0 & 4 & 29 \\
\hline \multicolumn{5}{|l|}{ Diptera (true flies) } \\
\hline Cricotopus sp. & 4 & 0 & 0 & 14 \\
\hline Micropsectra sp. & 4 & 0 & 4 & 29 \\
\hline Orthocladius sp. & 12 & 24 & 8 & 160 \\
\hline Pagastia sp. & 4 & 0 & 0 & 14 \\
\hline Palpomyia complex & 8 & 20 & 12 & 140 \\
\hline Parametriocnemus sp. & 88 & 56 & 140 & 1,000 \\
\hline Simulium sp. & 20 & 28 & 20 & 240 \\
\hline Thienemanniella sp. & 0 & 0 & 4 & 14 \\
\hline Thienemannimyia sp. group & 0 & 0 & 4 & 14 \\
\hline Chironomidae pupa & 4 & .4 & 4 & 43 \\
\hline \multicolumn{5}{|l|}{ CRUSTACEA } \\
\hline \multicolumn{5}{|l|}{ Amphipoda (sideswimmers) } \\
\hline Hyalella azteca & 0 & 0 & 16 & 57 \\
\hline \multicolumn{5}{|l|}{ OLIGOCHAETA (worms) } \\
\hline Eiseniella tetraedra & 0 & 0 & 4 & 14 \\
\hline Limnodrilus sp. & 68 & 4 & 12 & 300 \\
\hline TOTAL & 520 & 400 & 730 & 5,900 \\
\hline
\end{tabular}


Table 19.--Species list, replicate samples, and mean density of benthic invertebrates for selected sites on Fountain and Monument Creeks--Continued

\begin{tabular}{|c|c|c|c|c|}
\hline \multirow[t]{2}{*}{ Taxa } & \multicolumn{3}{|c|}{$\begin{array}{l}\text { Replicate sample, } \\
\text { number of organisms }\end{array}$} & \multirow{2}{*}{$\begin{array}{l}\text { Mean density, } \\
\text { numbers of organisms } \\
\text { per square meter }\end{array}$} \\
\hline & 1 & 2 & 3 & \\
\hline \multicolumn{5}{|c|}{$\frac{07103780 \text { MONUMENT CREEK ABOVE NORTH GATE BOULEVARD }}{\text { AT U.S. AIR FORCE ACADEMY (SITE M5) }}$} \\
\hline $\begin{array}{l}\text { INSECTA } \\
\text { Ephemeroptera (mayflies) } \\
\text { Baetis bicaudatus } \\
\text { Baetis tricaudatus } \\
\text { Ephemerella infrequens } \\
\text { Tricorythodes minutus }\end{array}$ & $\begin{array}{r}93 \\
36 \\
0 \\
33\end{array}$ & $\begin{array}{r}4 \\
4 \\
4 \\
93\end{array}$ & $\begin{array}{r}170 \\
130 \\
4 \\
14\end{array}$ & $\begin{array}{r}970 \\
610 \\
29 \\
500\end{array}$ \\
\hline $\begin{array}{l}\text { Plecoptera (stoneflies) } \\
\text { Isoperla sobria } \\
\text { Chloroperlidae } \\
\text { Perlodidae }\end{array}$ & $\begin{array}{l}1 \\
1 \\
1\end{array}$ & $\begin{array}{l}0 \\
1 \\
0\end{array}$ & $\begin{array}{l}0 \\
6 \\
2\end{array}$ & $\begin{array}{r}4 \\
29 \\
11\end{array}$ \\
\hline $\begin{array}{l}\text { Trichoptera (caddisflies) } \\
\text { Cheumatopsyche sp. } \\
\text { Hydropsyche sp. } \\
\text { Ochrotrichia sp. }\end{array}$ & $\begin{array}{r}15 \\
150 \\
1\end{array}$ & $\begin{array}{r}12 \\
92 \\
0\end{array}$ & $\begin{array}{r}18 \\
300 \\
0\end{array}$ & $\begin{array}{r}160 \\
2,000 \\
4\end{array}$ \\
\hline $\begin{array}{l}\text { Diptera (true flies) } \\
\text { Cricotopus sp. } \\
\text { Hexatoma sp. } \\
\text { Micropsectra sp. } \\
\text { Orthocladius sp. } \\
\text { Palpomyia complex } \\
\text { Parametriocnemus sp. } \\
\text { Phaenopsectra sp. } \\
\text { Simulium sp. } \\
\text { Thienemannimyia sp. group } \\
\text { Chironomidae pupa }\end{array}$ & $\begin{array}{r}1 \\
1 \\
2 \\
3 \\
0 \\
33 \\
1 \\
0 \\
1 \\
1\end{array}$ & $\begin{array}{r}4 \\
0 \\
0 \\
1 \\
4 \\
28 \\
1 \\
1 \\
1 \\
4\end{array}$ & $\begin{array}{r}12 \\
0 \\
2 \\
0 \\
2 \\
56 \\
0 \\
70 \\
0 \\
0\end{array}$ & $\begin{array}{r}61 \\
4 \\
14 \\
14 \\
22 \\
420 \\
7 \\
260 \\
7 \\
18\end{array}$ \\
\hline $\begin{array}{l}\text { Coleoptera (beetles) } \\
\text { Heterlimnius corpulentus }\end{array}$ & 3 & 1 & 2 & 22 \\
\hline $\begin{array}{l}\text { Odonata (dragonflies and } \\
\text { damselflies) } \\
\text { Ophiogomphus severus }\end{array}$ & 3 & 2 & 0 & 18 \\
\hline $\begin{array}{l}\text { CRUSTACEA } \\
\text { Amphipoda (sideswimmers) } \\
\text { Hyalella azteca }\end{array}$ & 1 & 0 & 2 & 11 \\
\hline $\begin{array}{l}\text { MOLLUSCA } \\
\text { Gastropoda (snails) } \\
\text { Lymnaea sp. }\end{array}$ & 0 & 1 & 0 & 4 \\
\hline $\begin{array}{l}\text { OLIGOCHAETA (worms) } \\
\text { Eiseniella tetraedra } \\
\text { Tubificidae }\end{array}$ & $\begin{array}{l}0 \\
5\end{array}$ & $\begin{array}{r}2 \\
19\end{array}$ & $\begin{array}{r}0 \\
10\end{array}$ & $\begin{array}{r}7 \\
120\end{array}$ \\
\hline TOTAL & 390 & 280 & 800 & 5,300 \\
\hline
\end{tabular}


Table 19.--Species list, replicate samples, and mean density of benthic invertebrates for selected sites on Fountain and Monument Creeks--Continued

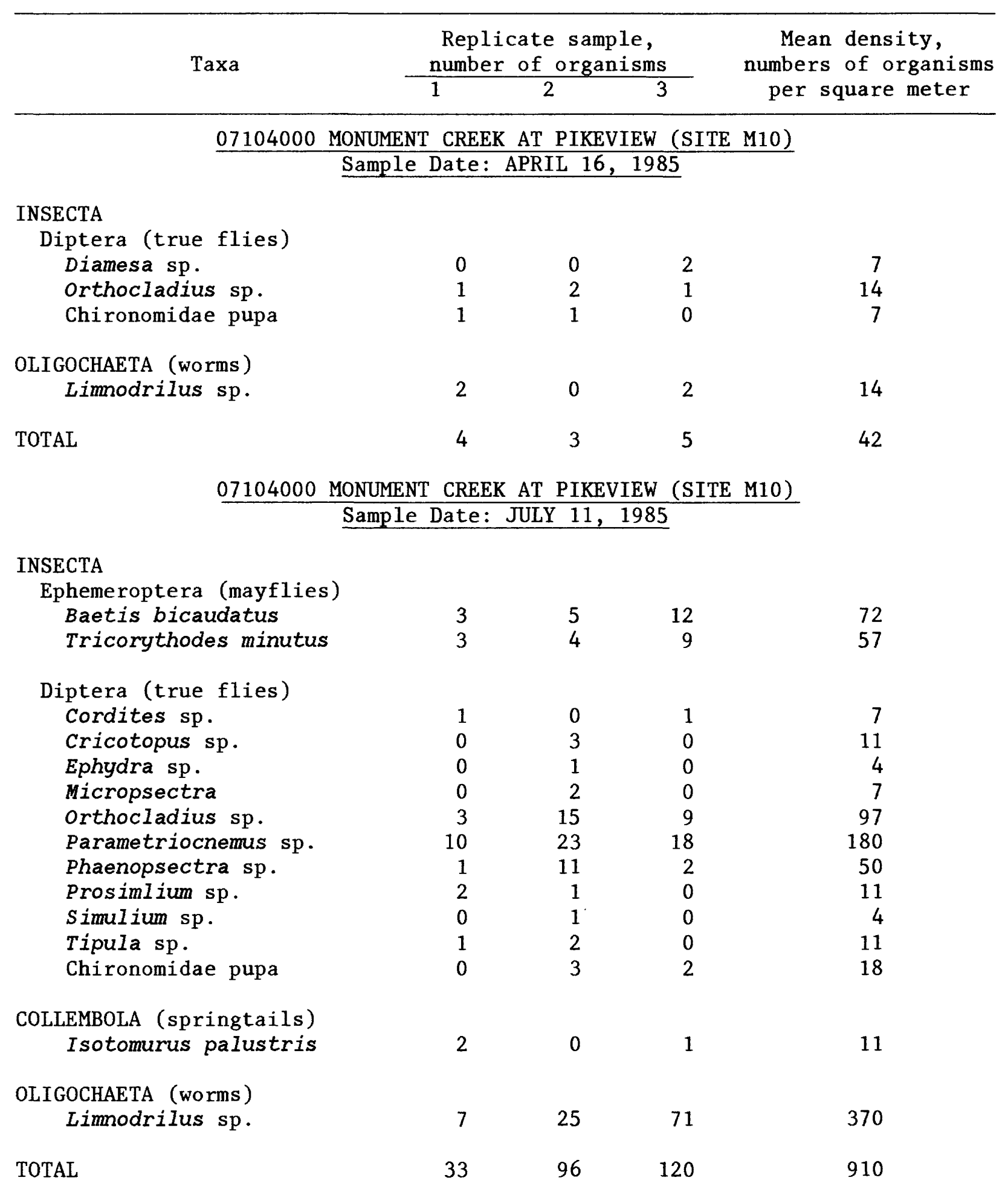


Table 19.--Species list, replicate samples, and mean density of benthic invertebrates for selected sites on Fountain and Monument Creeks--Continued

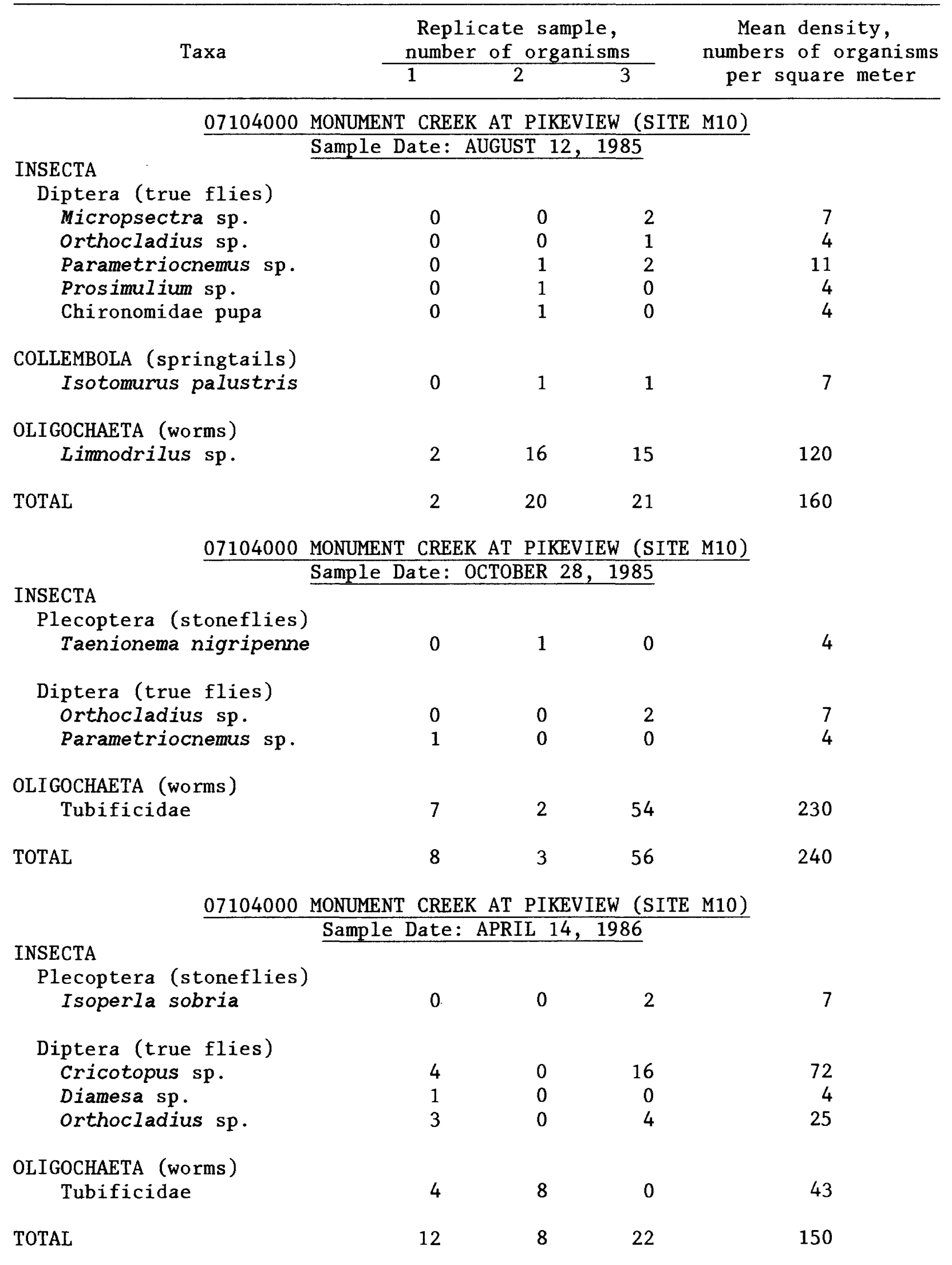


Table 19.--Species 1 ist, replicate samples, and mean density of benthic invertebrates for selected sites on Fountain and Monument Creeks--Continued

\begin{tabular}{|c|c|c|c|c|c|}
\hline \multirow[t]{2}{*}{ Taxa } & \multicolumn{3}{|c|}{$\begin{array}{l}\text { Replicate sample, } \\
\text { number of organisms }\end{array}$} & \multirow{2}{*}{\multicolumn{2}{|c|}{$\begin{array}{l}\text { Mean density, } \\
\text { numbers of organisms } \\
\text { per square meter }\end{array}$}} \\
\hline & & 2 & 3 & & \\
\hline \multicolumn{6}{|c|}{07104000 MONUMENT CREEK AT PIKEVIEW (SITE M10) } \\
\hline \multicolumn{6}{|c|}{ Sample Date: JULY 10, 1986} \\
\hline \multicolumn{6}{|l|}{ INSECTA } \\
\hline \multicolumn{6}{|l|}{ Ephemeroptera (mayflies) } \\
\hline Baetis bicaudatus & 1 & 0 & 2 & & 11 \\
\hline \multicolumn{6}{|l|}{ Diptera (true flies) } \\
\hline Chironomus sp. & 1 & 0 & 0 & & 4 \\
\hline Corynoneura sp. & 1 & 0 & 0 & & 4 \\
\hline Cricotopus sp. & 3 & 2 & 1 & & 22 \\
\hline Hexatoma sp. & 3 & 2 & 0 & & 18 \\
\hline Limnophora aequifrons & 0 & 4 & 0 & & 14 \\
\hline Micropsectra sp. & 2 & 40 & 23 & & 230 \\
\hline Orthocladius sp. & 0 & 2 & 3 & & 18 \\
\hline Palpomyia complex & 0 & 0 & 1 & & 4 \\
\hline Parametriocnemus sp. & 1 & 0 & 0 & & 4 . \\
\hline Prosimulium sp. & 1 & 0 & 0 & & 4 \\
\hline Simulium vittatum complex & 0 & 0 & 1 & & 4 \\
\hline Thienemanniella sp. & 0 & 0 & 1 & & 4 \\
\hline Chironomidae pupa & 0 & 2 & 1 & & 11 \\
\hline \multicolumn{6}{|l|}{ Coleoptera (beetles) } \\
\hline Heterlimnius corpulentus & 0 & 0 & 1 & & 4 \\
\hline HYDRACARINA (water mites) & 3 & 0 & 0 & & 11 \\
\hline \multicolumn{6}{|l|}{ CRUSTACEA } \\
\hline \multicolumn{6}{|l|}{ Amphipoda (scuds) } \\
\hline Gammarus lacustris & 1 & 0 & 0 & & 4 \\
\hline \multicolumn{6}{|l|}{ OLIGOCHAETA（worms） } \\
\hline Eiseniella tetraedra & 1 & 0 & 1 & & 7 \\
\hline Tubificidae & 17 & 34 & 22 & & 260 \\
\hline TOTAL & 35 & 86 & 57 & & 640 \\
\hline
\end{tabular}


Table 19.--species list, replicate samples, and mean density of benthic invertebrates for selected sites on Fountain and Monument Creeks--Continued

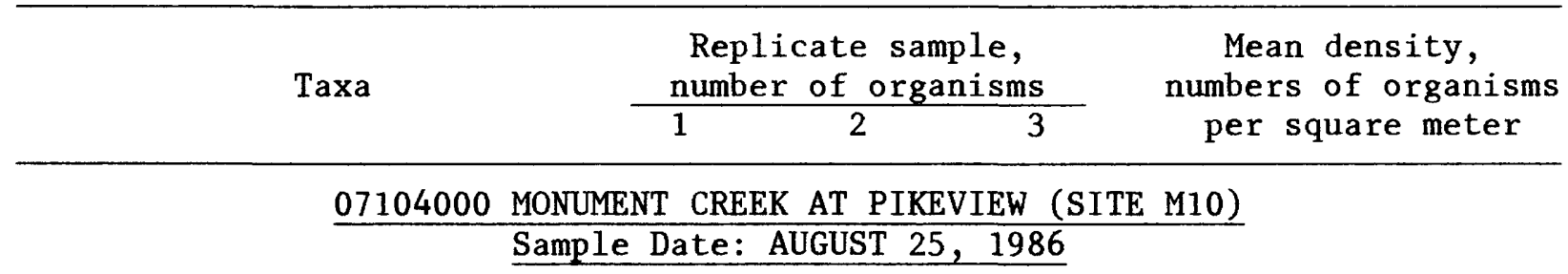

INSECTA

Ephemeroptera (mayflies)

Baetis tricaudatus

$4 \quad 0 \quad 0 \quad 14$

Diptera (true flies)

Cryptochironomus sp.

Parametriocnemus $\mathrm{sp}$.

Prodiamesa sp.

$0 \quad 0 \quad 3$

$0 \quad 1 \quad 0$

11

$\begin{array}{llll}12 & 2 & 4 & 65\end{array}$

OLIGOCHAETA (worms)

Limnodrilus sp.

$24 \quad 3 \quad 110$

TOTAL

$\begin{array}{lll}40 & 6 & 10\end{array}$

200

07104000 MONUMENT CREEK AT PIKEVIEW (SITE M10)

Sample Date: NOVEMBER 5, 1986

INSECTA

Diptera (true flies)

Micropsectra sp.

Orthocladius sp.

Parametriocnemus sp.

Prodiamesa sp.

Chironomidae pupa

20

100

$3 \quad 18$

$\begin{array}{llll}5 & 3 & 35 & 150\end{array}$

$\begin{array}{llll}0 & 3 & 3 & 22\end{array}$

GOCHAETA (worms)

Limnodrilus sp.

$\begin{array}{llll}83 & 52 & 85 & 790\end{array}$

TOTAL

$91 \quad 59 \quad 126$

990

07104000 MONUMENT CREEK AT PIKEVIEW (SITE M10) SAMPLE DATE APRIL 27, 1987

INSECTA

Diptera (true flies)

Cryptochironomus sp.

Orthocladius sp.

Parametriocnemus sp.

0

3

8

1

4

0

3

OLIGOCHAETA (worms)

Limnodrilus sp.

22

220

68

1,100

TOTAL

33

220

74

1,200 
Table 19.--Species list, replicate samples, and mean density of benthic invertebrates for selected sites on Fountain and Monument Creeks--Continued

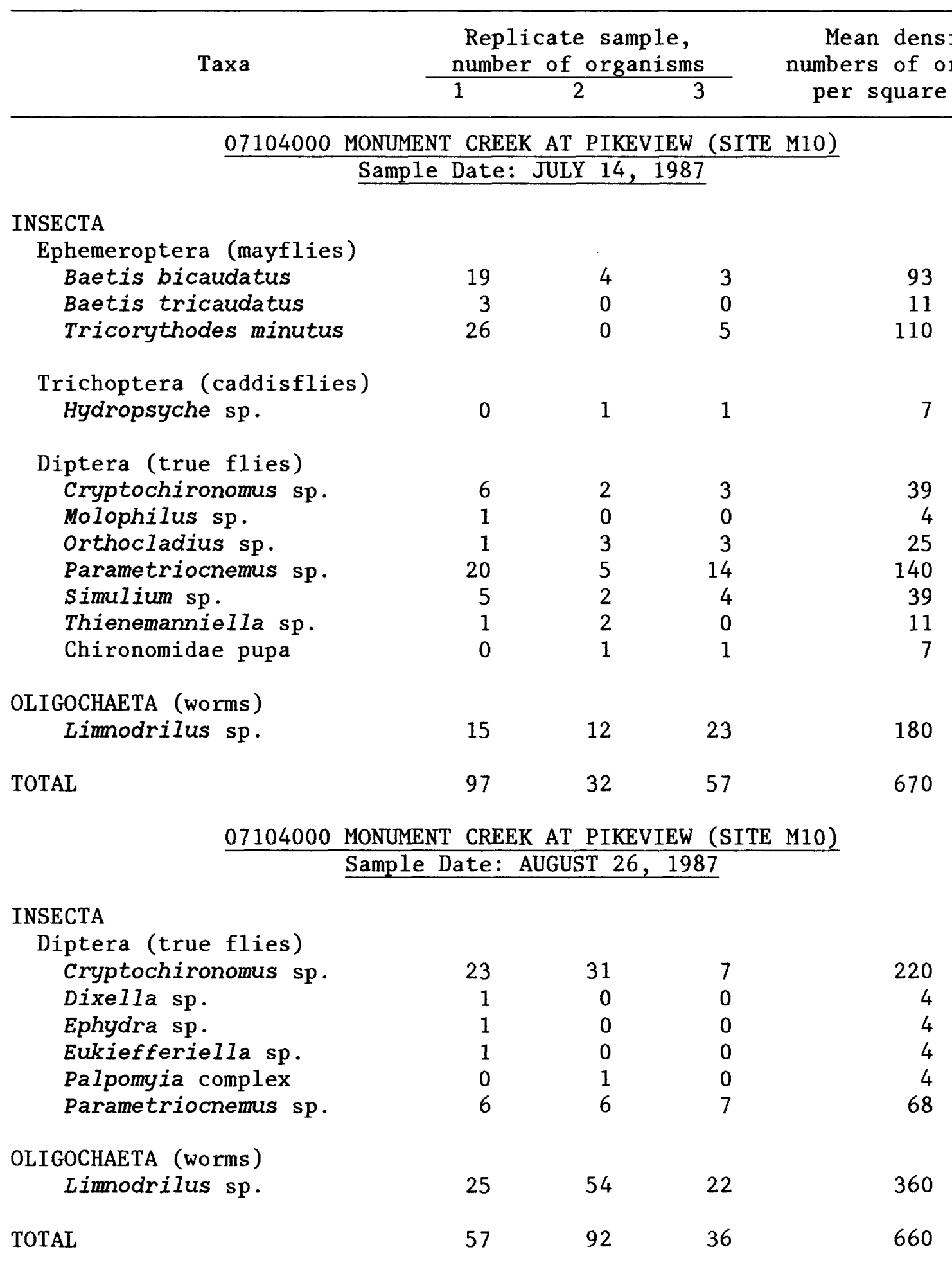


Table 19.--Species list, replicate samples, and mean density of benthic invertebrates for selected sites on Fountain and Monument Creeks--Continued

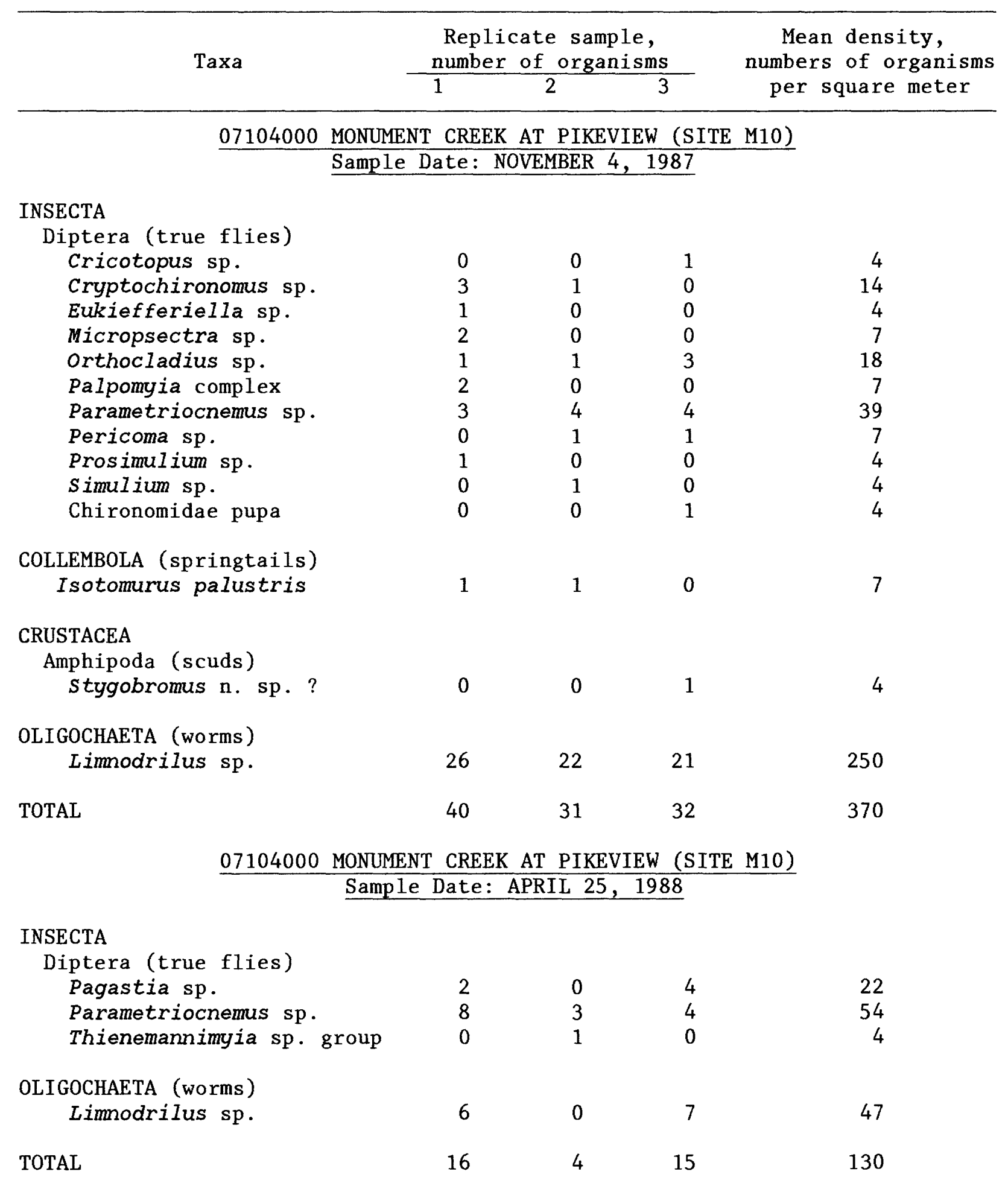


Table 19.--Species list, replicate samples, and mean density of benthic invertebrates for selected sites on Fountain and Monument Creeks--Continued

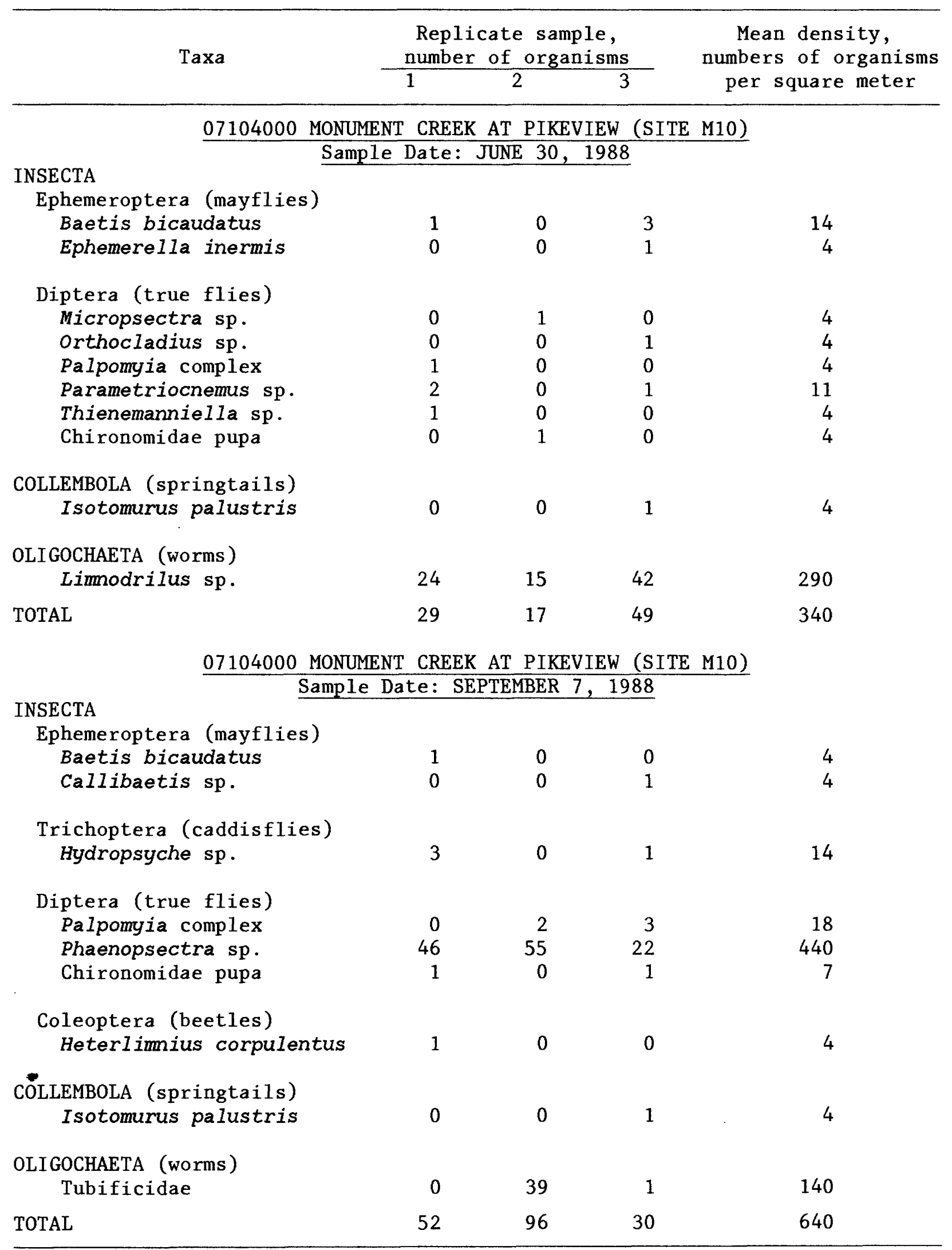

